\title{
SANATORIUM OF THE SOUTH? \\ PURLIC HEALTH AND POLITICS \\ IN HOBART AND LAUNCESTON 1875-1914.
}

STEFAN PETROW B.A.Hons., Dip.Lib.

Submitted in fulfilment of the requirements

of the degree of Master of Arts.

UNIVERSITY OF TASMANIA

HOBART FEBRUARY 1984. 
This thesis contains no material which has been accepted for the award of any other higher degree or graduate diploma in any university and that, to the best of this candidate's knowledge and belief, the thesis contains no copy or paraphrase of material previously published or written by another person, except where due reference is made in the text of the thesis.

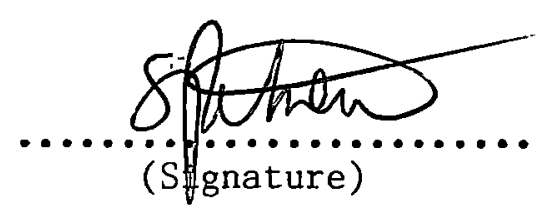




\section{ACKNOWLEDGEMENTS}

I gratefully acknowledge the assistance of my supervisor Michael Roe. By patiently reading through numerous drafts and making many constructive suggestions he has helped to make this thesis better than it otherwise would have been. Rodney Quinn kindly proof-read the thesis. Any errors of fact or interpretation are my own.

I thank the Hobart and Launceston City Councils for granting me access to their records. Staff of the following institutions were very helpful: in particular the staff of the Archives Office of Tasmania, who provided a model service and cheerfully put up with a somewhat intrusive researcher; the Tasmanian Collection and Reference Section of the State Library of Tasmania; the Photography Section, University of Tasmania; the Tasmanian Parliamentary Library; the Interlibrary Loan Section, Morris Miller Library, University of Tasmania; the Northern Regional Library, Launceston; and the Library of the Australian Medical Association, Melbourne. Sue Court expertly typed the thesis. I also thank my mother for her unstinting help in various ways. Finally I dedicate this thesis to other part-time researchers: may they finish, not perish. 


\section{TABLE OF CONTENTS}

\begin{tabular}{|c|c|c|}
\hline & & Page \\
\hline INTRODUCTION & & 1 \\
\hline PART ONE: $\quad$ BACK & UND & 10 \\
\hline CHAPTER ONE. & SURROUNDED BY MUCK 1803-1885 & 11 \\
\hline & Launceston & 19 \\
\hline & Hobart & 28 \\
\hline PART TWO: LAUN & TON 1886-1914 & $39 a$ \\
\hline CHAPTER TWO. & "THE BEST GOVERNED CITY" IN AUSTRALIA & 40 \\
\hline CHAPTER THREE. & THE CITY HEALTH DEPARTMENT & 84 \\
\hline CHAPTER FOUR. & WASTES & 113 \\
\hline & The Removal of Refuse & 113 \\
\hline & Nightsoil & 118 \\
\hline & $\begin{array}{l}\text { a) The Pan System of Nightsoil } \\
\text { Removal }\end{array}$ & 118 \\
\hline & b) Launceston's Sewerage Scheme & 121 \\
\hline CHAPTER FIVE. & VESTED INTERESTS & 144 \\
\hline & a) Housing & 144 \\
\hline & b) Noxious Trades & 160 \\
\hline & c) Cemeteries & 175 \\
\hline & d) Factory Inspection & 181 \\
\hline PART THREE: $\mathrm{HO}$ & T 1886-1914 & $189 \mathrm{a}$ \\
\hline CHAPTER SIX. & THE POLITICS OF SANITARY IMPROVEMENT & 190 \\
\hline CHAPTER SEVEN. & THE CITY HEALTH DEPARTMENT & 242 \\
\hline CHAPTER EIGHT. & WASTES & 269 \\
\hline & The Removal of Refuse & 269 \\
\hline & Nightsoil & 282 \\
\hline & $\begin{array}{l}\text { a) The Pan System of Nightsoil } \\
\text { Removal }\end{array}$ & 282 \\
\hline & b) Water closets and Rivulets & 292 \\
\hline & c) Metropolitan Drainage & 302 \\
\hline
\end{tabular}


Page

$\begin{array}{lll}\text { CHAPTER NINE. } & 321\end{array}$

a) Housing 321

b) Noxious Trades 341

C) Cemeteries 353

d) Factory Inspection 358

$\begin{array}{ll}\text { CONCLUSION } & 367\end{array}$

$\begin{array}{ll}\text { APPENDIX A. } & 374\end{array}$

$\begin{array}{ll}\text { BIBLIOGRAPHY } & 376\end{array}$ 


\section{TABLES}

\section{Page}

Table 1: Estimated Population of Launceston.

Table 2: Launceston Corporation Rates Levied in $58 a$ the Pound.

Table 3: Occupations of Launceston Aldermen. $65 a$

Table 4: Money Allocated to Particular Sections of $74 a$ Launceston 1893-7.

Table 5: Scale of Voting at Launceston Municipal $76 a$ Elections.

Table 6: Cases of Infectious Diseases Notified in $84 a$ Hobart $(\mathrm{H})$ and Launceston $(\mathrm{L})$.

Table 7: $\quad$ Cases of Infectious Diseases in Parts of Launceston.

Table 8: Launceston's Death Rate per 1000.

Table 9: Launceston's Infant Mortality Rate.

Table 10: Methods of Dealing with Nightsoil in Launceston.

Table 11: Deaths from Typhoid Fever in Launceston and Rate per 100,000.

Table 12: Estimated Population of Hobart. 191

Table 13: Scale of Voting at Hobart Municipal $206 a$ Elections.

Table 14: Value of Property Built in Hobart. 220

Table 15: Hobart Corporation Rates Levied in the Pound.

Table 16: Occupations of Hobart Aldermen.

Table 17: Hobart's Death Rate per 1000. 
Table 18: Hobart's Infant Mortality Rate.

Table 19: Number of Water closets in Hobart.

Table 20: City of Hobart - Cases and Deaths of

$320 a$

Typhoid Fever Recorded in Medical Officers of Health Annual Reports.

Table 21: Deaths from Typhoid Fever in Hobart $320 b$ Registration District and Rate per 100,000. 


\section{PLATES}

Between

Pages

Dr. Edward Swarbreck Hall

$15-16$

Dr. Edward Owen Giblin

$32-33$

The Hobart Slaughteryard c.1871

$35-36$

Aldermen S.J. Sutton, C. Russen, J.W. Pepper

$49-50$

Aldermen P. McCrackan, R.J. Sadler, D. Storrer

$78-79$

Dr. John Thomas Wilson

$101-2$

Dr. Lavington Grey Thompson

$106-7$

Charles St. John David

$130-31$

Low standard housing in Margaret Street, Launceston

$150-51$ c. 1903

Alderman J. Bradley; Edward Mulcahy; Herbert Nicho1ls; 215-16 Alderman J.G. Davies

Aldermen T. Bennison, G.E. Moore, R.J. Meagher,

W.M. Williams

Dr. Gregory Sprott

$250-51$

Dr. Gerard Smith

$257-8$

The Hobart Rivulet c.1913

$292-3$

View of Hobart from the Glebe c.1890s

$337-8$

Low standard housing in the Wapping area of Hobart

$338-9$ .c. 1910-13 


\section{MAPS}

Between

Pages

Launceston c.1928

$66-67$

Launceston c.1891

$68-69$

Hobart c.1915

196-7

(ix) 
ABBREVIATIONS

A.D.B. $\quad$ Australian Dictionary of Biography.

A.J.P.H. Australian Journal of Politics and History.

C.B.H. Central Board of Health.

C1. $\quad$ Clipper.

C.S.D. $\quad$ Chief Secretary's Department.

C.S.0. Colonial Secretary's Office.

D.P. $\quad$ Daily Post.

D.T. Daily Telegraph.

Ex. $\quad$ Examiner.

H.A.P. House of Assembly Papers.

L.C.P. $\quad$ Legislative Council Papers.

M. $\quad$ Mercury.

M.D.B. Metropolitan Drainage Board.

P.P.R.S.T. Papers and Proceedings of the Royal Society of

Tasmania.

R.P.I.G. Register and Property Investor's Guide.

S.S. Southern Star.

T.D. Tasmanian Democrat.

T.H.R.A. Tasmanian Historical Research Association Papers

and Proceedings.

T.N. Tasmanian News.

T.P.P. Tasmanian Parliamentary Papers.

T.T. Tasmanian Tribune.

V.P.P. $\quad$ Victorian Parliamentary Papers. 


\section{ABSTRACT}

In the nineteenth century boosters claimed that Tasmania was the Sanatorium of the Australian colonies, an island where the sick could gain new vitality and where a long and healthy life was assured. This image was projected in order to attract tourists and immigrants. However the insanitary conditions of the two major cities, Hobart and Launceston, resulted in a series of epidemics of infectious diseases in the 1880s and cast doubt upon the salubrity of the island. This thesis examines the cause of these epidemics and other public health problems faced by the two cities and assesses the way in which public health responsibilities were discharged by the City Councils of Hobart and Launceston, concentrating on the period 1885 to 1914. Detailed study begins in 1885 when the Public Health Act, the most important Tasmanian statute on health in the nineteenth century, was passed.

Part One surveys sanitary conditions in the two cities before 1885, focusing on the decade from 1875 when, after years of insouciance, epidemics forced the two Councils to give some attention to sanitary problems. Part Two on Launceston and Part Three on Hobart each includes chapters on the political context in which public health problems were considered, looking particularly at the direction municipal reform took and explaining the enlargement of municipal powers; on the indispensable role of Health Officers, who were usually the only members of municipal councils with training in preventive medicine; on how Councils cleared the environment of accumulations of 
filth and sewage, those fertile sources of infectious disease; and on how vested interests impeded municipal regulation of insanitary housing, noxious trades, cemeteries and factories. A central theme is that political and economic considerations were frequently more important than the imperatives of preventive medicine in determining whether sanitary reforms would be implemented. Property owners were the most influential pressure group in municipal politics and were often successful in opposing sanitary reform when it seemed to threaten their interests. However, assisted by the shock impact of epidemics, especially of typhoid, and the growth of civic consciousness, sanitary reformers were able to persuade the City Councils to clean up the urban environment. Consequently, although failing badly in crucial areas, particularly housing, the evidence suggests that the sanitary improvements implemented by the Hobart and Launceston Corporations contributed to a steady decline in the general death rate and a reduction in the incidence of infectious diseases. 


\section{INTRODUCTION}

"The history of mankind", Hartwell has written, "is the history of poverty, dirt and disease. Life for most men for most of history has been a constant struggle for survival, in an insanitary environment, against poverty and disease". ${ }^{1}$ Infectious diseases have shaped the course of history and social historians have recently started to investigate their impact on society. ${ }^{2}$ Two wide ranging works have appeared within the last five years: Smith has examined the numerous factors affecting the health of British people between 1830 and 1910 and Wohl has complemented Smith by focusing on public health in Victorian Britain. ${ }^{3}$ The health of urban residents looms large in the works of Smith and Wohl because death rates from all diseases were generally higher in cities than in rural areas. Urban history has grown in popularity over the last two decades but detailed work on disease in nineteenth century cities remains to be done, as Luckin indicated in $1980 .{ }^{4}$ This

1. R.M. Hartwe11, "The Economic History of Medical Care" in M. Perlman (ed.), The Economics of Health and Medical Care, (London, 1974), p.4.

2. For the effect of disease throughout history see W.H. McNeill, Plagues and Peoples, (Harmondsworth, 1979); for reviews of the literature see J. Woodward and D. Richards, "Towards A Social History of Medicine", in J. Woodward and D. Richards (eds.), Health Care and Popular Medicine in Nineteenth Century England: Essays in the Social History of Medicine, (London, 1977), p.15-55 and G. Grob, "The Social History of Medicine and Disease in America: Problems and Possibilities", Journal of Social History, v.10, 1977, p.391-409.

3. F.B. Smith, The People's Health 1830-1910, (Canberra, 1979); A.S. Woh1, Endangered Lives: Public Health in Victorian Britain, (London, 1983).

4. For a recent account of the progress of urban history in Britain and America see D. Cannadine, "Urban History in the United Kingdom: The 'Dyos Phenomenon' And After", in D. Cannadine and D. Reeder (eds.), Exploring the Urban Past: Essays in Urban History by H.J. Dyos, (Cambridge 1982), p.20321; B. Luckin, "Death and Survival in the City: Approaches to the History of Disease", Urban History Yearbook 1980, p. 53-62. 
thesis intends to redress this situation in Tasmania by examining the way in which the municipal councils of Hobart and Launceston, the two major cities, dealt with public health problems between 1885 and 1914. Although Tasmania had a reputation in the nineteenth century as being the Sanatorium of the Australian colonies, an island with an equable climate where a healthy and long life was assured, it is argued that for Launceston and Hobart this image did not correspond with reality and that infectious diseases were rife. 5

The intention is not to "merely recount the course of an epidemic" but, to some extent, "to encompass the environmental, social and political contexts of health and ill-health. "6 Thus for Parts 2 and 3 the municipal reform movements in Launceston and Hobart respectively will be studied, explaining the enlargement of municipal functions and stressing the role of sanitary reformers in fostering municipal reform. Each Part will also contain chapters on the crucial role of Health Officers; on how the environment was cleaned up by the removal of wastes, such as refuse and night soil; and on the problems faced by Corporations when dealing with insanitary housing, noxious trades, cemeteries and factories. Without excluding the influence of other factors, it will be claimed that, in both cities, death rates were lowered,

5. For the salubrity of the island see T.E. Dempster, "Climate of Van Diemen's Land As A Resort For Invalids From India", Transactions of The Medical And Physical Society, Calcutta v. VII, 1835, p.357-362 extracted in J.H.L. Cumpston, The History of Diphtheria, Scarlet Fever, Measles and Whooping Cough In Australia 1788-1925, (Melbourne, 1927), p.304-6 and C.A. Morris, "In Pursuit Of The Travelling Man: A Study of Tasmanian Tourism To 1905", unpublished B.A. Hons. Thesis, University of Tasmania, 1974.

6. F.B. Smith, "Illness At The.Inn: A Review of Endangered Lives: Public Health In Victorian Britain by A.S. Wohl", London Review of Books, v.5, No. 14, August 1983, p.11. 
mainly because of general sanitary improvements. 7

Although individual epidemics will not be studied in detail, it is argued that epidemics precipitated change in sanitary administration. 8 Prior to 1886 the municipal councils of Launceston and Hobart tended to neglect sanitary problems until the appearance of an epidemic: after the epidemic subsided neglect would again prevail. From 1887 epidemics of infectious diseases, particularly typhoid fever, which were regarded as preventable, became more frequent and the councils were forced to give regular attention to sanitation. Sanitation, particularly in Hobart, became an important political issue, generating much heat at municipal elections. Irrespective of whether the miasma or pythogenic theory of disease causation, which linked filth and smells with disease or, increasingly from the mid-1890s, the germ theory, which held that disease was spread by a living organism, held sway, the ultimate implementation of sanitary measures was often not based on the objective medical information provided by Health Officers but on subjective political and economic considerations. ${ }^{9}$ By

7. A controversial debate on the decline of mortality in Britain was initiated by T. Mckeown see, for example, The Modern Rise Population, (London, 1976) and later in The Role of Medicine, (Oxford, 1979). For a critical survey of the issues involved in the debate, which centres on McKeown's claim that nutrition and personal and public health reform lowered death rates from infectious diseases and not medical advances see J.M. Winter, "The Decline Of Mortality In Britain 1870-1950", in T. Barker and M. Drake (eds.), Population And Society In Britain 1850-1980, (London, 1982), p.100-20.

8. This was also the case elsewhere see J.W. Leavitt, The Healthiest City: Milwaukee and the Politics of Health Reform, (Princeton, 1982), p.242.

9. For discussion of theories of disease causation see R. Lambert, Sir John Simon 1816-1904 and English Social Administration, (London, 1963), p.49-54 and M. Pelling, Cholera, Fever and English Medicine 1825-1865, (Oxford, 1978), p.59-62, 296ff. 
considering the interest groups for and against sanitary reform, some understanding can be gained of the nature of power and how it was used within an urban context. 10 In both cities the interests of property owners in municipal affairs were paramount. ${ }^{11}$

Despite the growth, since the beginning of the 1970s, of Australian urban history little research has been carried out on the role of municipal councils and the impact of disease in major cities. $^{12}$ City biographies, the dominant genre of Australian urban history, usually include some material on Corporations and disease: Stannage on Perth has given the most attention to these subjects. $^{13}$ of the municipal councils of capital cities only that of Brisbane has received extended treatment, by Greenwood and Laverty. ${ }^{14}$ The only published work to concentrate on urban ill-health is Mayne's recent book on the Sydney Corporation's management of sanitation in the Victorian era. ${ }^{15}$ By showing the grave problems of disease, dirt and, above all, insanitary housing,

10. For the importance of the study of power see J. Garrard, "Social History, Political History and Political Science: The Study of Power", Journal of Social History, v.16, No. 3, 1983, p.10521; D.C. Hammack, "Problems in the Historical Study of Power in the Cities and Towns of the United States, 1800-1960", American Historical Review, v.83, 1978, p.323-49; C.T. Stannage, "Australian Urban History" in G. Osborne and W.F. Mandle (eds.), New History: Studying Australia Today, (Sydney, 1982), p.174.

11. Property relations in cities have recently engaged the attention of historians see A. Offer, Property and Politics, 1870-1914, (Cambridge, 1981) and D. Englander, Landlord and Tenant in Urban Britain 1838-1918, (Oxford, 1983).

12. For urban history in Australia see Stannage, op.cit.; G. Davison, "Australian Urban History: A Progress Report", Urban History Yearbook, 1979, p.100-09; B. Fletcher, "Urban Society in Australia: Writings and Approaches", Teaching History, v.17, Part 2, 1983, p.15-30.

13. C.T. Stannage, The People of Perth: A Social History of Western Australia's Capital City, (Perth, 1979).

14. G. Greenwood and J. Laverty, Brisbane 1859-1959: A History of Local Government, (Brisbane, 1959).

15. A.J.C. Mayne, Fever, Squalor and Vice: Sanitation and Social Policy in Victorian Sydney, (St. Lucia, 1982). 
experienced by the residents of Sydney, Mayne has covered many of the themes to be explored in this thesis. The comparative approach adopted in this thesis requires comment. A significant feature of British urban history has been the attempt at comparative studies by, for example, Briggs, Hennock, Fraser and Garrard, each of whom, while having different aims, has placed municipal councils and the nature of urban management at the centre of their analyses. 16 Calls for the comparative approach to Australian urban history have largely gone unanswered. 17 Cannon has somewhat superficially examined life, including sanitary conditions, in major Australian cities in the Victorian age. 18 Barrett has attempted comparison of the Melbourne suburbs of Collingwood and Fitzroy, with emphasis on industrial and night soil pollution and how the councils coped with it. ${ }^{19}$ This thesis, however, is the first attempt to systematically compare the municipal councils of two Australian cities within a region and as such breaks new ground.

16. A. Briggs, Victorian Cities, (Harmondsworth, 1980); E.P. Hennock, Fit and Proper Persons: Ideal and Reality in Nineteenth-Century Urban Government, (London, 1973). D. Fraser, Urban Politics in Victorian England: The Structure of Politics in Victorian Cities, (London, 1979) and Power and Authority in the Victorian City, (Oxford, 1979); J. Garrard, Leadership and Power in Victorian Industrial Towns 1830-80, (Manchester, 1983).

17. J. McCarty, "Melbourne, Ballarat, Sydney, Perth: The New City Histories", Historical Studies, v.19, No. 74, 1980, p.13. On the usefulness of the comparative approach in urban history see A.J.C. Mayne, "The Question of the Poor in the Nineteenth Century City", Historical Studies, v.20, No.81, 1983, p.55773.

18. M. Cannon, Australia in the Victorian Age v.3: Life in the Cities, (Melbourne, 1978), Part IV is on Public Health.

19. B. Barrett, The Inner Suburbs: The Evolution of an Industrial Area, (Melbourne, 1971). 
Previous research on Launceston and Hobart has not given municipal councils the attention they deserve. City biographies by Reynolds on Launceston and by Bolger and the urban geographer Solomon on Hobart contain only scattered references to either municipal government or urban health. 20 Few other works have examined these subjects at length. Chapters on Launceston and Hobart are included in von Stieglitz's unsatisfactory short history of local government in Tasmania. ${ }^{21}$ Roe has examined the establishment of municipal government in Launceston and Hobart and the impact of smallpox epidemics in Launceston in 1887 and 1903.22 The career of Hobart's first Health Officer Dr. E.S. Hall has been the subject of a thesis by Haynes. ${ }^{23}$ Finally Rimmer included some material on public health in his history of the Hobart General Hospital, as did Brown in her book on the provision of social services in nineteenth century Tasmania. ${ }^{24}$ While these works

20. J. Reynolds, Launceston: History of an Australian City, (South Melbourne, 1969); P. Bolger, Hobart Town, (Canberra, 1973); R.J. Solomon, Urbanisation: The Evolution of an Australian Capital, (Sydney, 1976).

21. K.R. von Stieglitz, A History of Local Government in Tasmania, (Launceston, 1958).

22. M. Roe, "The Establishment of Local Self-government in Hobart and Launceston", T.H.R.A., v.14, No. 1, 1966, p.21-45 and "Sma1lpox in Launceston, 1887 and 1903, T.H.R.A., v.23, No.4, 1976, p.111-48.

23. E.F. Haynes, "Edward Swarbreck Ha11: Medical Scientist and Social Reformer in Colonial Tasmania", unpublished M.A. Thesis, University of Tasmania, 1976.

24. W.G. Rimmer, Portrait of a Hospital: The Royal Hobart, (Hobart, 1981). This book contains some curious lapses. For example on p.137 he implies that in $1885 \mathrm{Hall}$ was in charge of the Central Board of Health but he died in 1881. J.C. Brown, "Poverty is not a Crime': The Development of Social Services in Tasmania 1803-1900, (Hobart, 1972). 
provide useful background material, none pay much attention to the key decades from 1885 to 1914 when the scope of municipal government was expanded and, by gradually overcoming the ravages of infectious diseases like typhoid, urban life was made more healthy and safe.

Among the principal sources consulted for this thesis were the records of the two municipal councils. For the Hobart Corporation, the State Archives has extensive holdings of minute books for meetings of the whole Council and of the Water, Sewerage, Public Works, Slaughteryard, Sanitary and Health committees and from 1886 of the Local Board of Health. The Launceston Corporation has retained its records, which are not well organised, making their use difficult, and only the minute book of the whole Council from 1852 to 1886 has been examined. As is the case with minute books only the topic of discussion and the decision reached was recorded. However full records of general Council meetings of the Hobart and Launceston Corporations were published in the daily newspapers of each city, the Mercury and the Examiner respectively. Unamended newspaper cuttings of these municipal debates, the valedictory addresses of Mayors and the annual and special reports of Health Officers and other civic officials, were attached to the pages of minute books, possibly an indication of their veracity. However footnote references in this thesis are usually to the newspapers themselves and not to the cuttings in minute books.

Newspapers were also used for editorial opinion on current issues and the opinion of citizens as expressed through letters or reports of speeches at public meetings. For both cities newspapers of different political views, conservative, liberal and labour, have been used to give balanced and alternative comments 
of events. As the records of the Central Board of Health, established in 1885 to assist local authorities with sanitary problems, and various citizens groups interested in sanitary and municipal reform, have not survived, newspaper reports were indispensable as being the only record of their activitiés. To augment their powers and obtain loans for public works municipal councils were required to obtain parliamentary sanction and important issues were often raised in debates. However no official record of parliamentary debates was produced and historians are forced to consult newspaper accounts for attitudes to the representations of councils. Parliamentary papers have been used for annual reports of the Central Board of Health and from 1904 the Department of Public Health and for evidence given to select committees and royal commissions. The government gazette has provided information on the balance sheets and by-laws of the two Corporations. The Royal Society of Tasmania displayed an interest in public health, talks on which were often given. These talks, with subsequent discussions by members, were published in the Society's Papers and Proceedings and acted as a forum for debate on sanitary issues. - The only major source not fully exploited was assessment rolls. Property owners, as was noted earlier, were an important pressure group in municipal politics. As assessment rolls list, street by street, the owners of individual properties, a clear indication of who were the largest property owners can be gained: it could be objectively established whether aldermen were actually among the largest property owners and landlords, as was often alleged. To compile figures on property ownership from assessment rolls for one city for selected years takes up much time: the magnitude of the task for two cities is beyond the endurance of one part-time researcher. 
Given the high property qualification for aldermanic seats, $£ 100$ in Hobart until 1914 and in Launceston until 1895, it is assumed that aldermen, particularly in Hobart, were in the top bracket of property owners. Before examining the Launceston and Hobart Corporations in depth, an outline of the measures taken to improve urban health in the period up to 1885 will be provided. 


\begin{abstract}
"It is a beautiful, noble island. In most, if not all, of those features which constitute the strength, the wealth and the grandeur of a country it has been endowed. The seas which encompass it, the lakes and rivers which refresh and fertilise, the woods which shadow, and the genial sky which arches it, all bear testimony to the excellence of the Divine hand .... The climate is more than healthful; it is invigorating and inspiring. Breathing it manhood preserves its bloom, vivacity, and vigor, long after the period at which, in other countries, those precious gifts depart, and the first touch of age is felt .... Breathing it many a frail form, which the Indian sun had wasted, acquires a fresh life; the dim eye lights up anew, and to the ashy paleness of the sunken cheek succeeds the sparkling blush of health ...."
\end{abstract}

A description of Tasmania's climate by one of the Irish exiles in 1850 quoted in T.N. 16 October 1911 .

"Thanks to a temperate and salubrious climate the people of Tasmania as a whole have persistently neglected the most common rules of sanitary science for 50 or 60 years with comparative impunity, but as population becomes denser, and the accumulation of filth and sewage increases, the question of hygiene is forced upon public attention by the periodic outbreak of epidemic diseases and the sacrifice of human life."

Ex. 12 January 1888. 
CHAPTER ONE

\section{SURROUNDED BY MUCK 1803-1885}

Over the centuries nature had created of the island, first named Van Diemen's Land and later Tasmania, an arcadian paradise in the Southern Hemisphere. The island provided a disease free environment for the convicts and free settlers, who settled at Hobart on the River Derwent from 1803 and at Launceston on the River Tamar, from 1806, an environment that must have been a stark contrast to the insanitary conditions of Great Britain. ${ }^{1}$ However as towns slowly grew around these settlements the "virgin purity" of the environment waned and regulation was necessary to stop further deterioration. ${ }^{2}$ The first legislation was the Police Act 1833, which provided for the "decency, order and cleanliness" of the two cities. ${ }^{3}$ Enforced by the police, it was apparently of little help as epidemics of typhus fever and scarlet fever occurred in 1839-40 and 1843 respectively. ${ }^{4}$ One of the few authoritative reports of this period, in October 1843, by the medical officer of Hobart Dr. Robert Officer, found that sanitary

1. Although Hobart Town was the name used until 1881, Hobart will be used throughout this thesis: Hobart became a city in 1842. For the settlement of Hobart see P. Bolger, Hobart Town, (Canberra, 1973), Chapter 1 and for Launceston see J. Reynolds, Launceston: History of an Australian City, (South Melbourne, 1969), Chapter 2.

2. For the general problems caused by European impact on a "new." country see B. Gandevia, "The Medico-Historical Significance of Young and Developing Countries, Illustrated by Australian Experience" in E. Clarke (ed.), Modern Methods in the History of Medicine, (London, 1971), p. $75-98$.

3. A.G.L. Shaw, Sir George Arthur, Bart 1784-1854, (Melbourne, 1980), p.148-49.

4. J.H.L. Cumpston, The History of the Intestinal Infections (and Typhus Fever) in Australia 1788-1923, (Melbourne, 1927), p.416-17; J.H.L. Cumpston, The History of Diphtheria, Scarlet Fever, Measles and Whooping Cough in Australia 1788-1925, (Melbourne, 1927), p.8, 145, 264. 
conditions were not good. ${ }^{5}$ In his report Officer showed an awareness of recent investigations into the sanitary conditions of towns in Great Britain. ${ }^{6}$ officer conceded that the colonies, by their isolated position and salubrious climate, were free from some of the diseases "which commit the greatest havoc among the population of Great Britain", but the rapid increase in the size of Hobart, from 6,000 in 1830 to 14,602 in 1841 , required the adoption of certain sanitary precautions. 7 By 1843 the average mortality of Hobart was "not less than that in the towns of our native land" and the reasons were palpable. The Hobart Rivulet was from beginning to end "one of the most fertile sources of sickness". The four burial grounds were a disgrace. He continued: Dunghills, pigstyes, neglected privies, stagnant water and other accumulations of offensive matters are everywhere to be seen and exert a most unfavourable influence on the public health. There was a desperate need for a regular system of scavenging. Pure water was scarce and Officer claimed that water was so expensive that many people were driven to use "the foul water of the Town Creek, not only for washing but for their common drink". Finally officer found in many butcher shops "the most disgusting accumulations of filth" and slaughtering was carried out in violation of the Slaughtering of Sheep and Cattle Act 1830. Although a similar report on Launceston has not been found, it is unlikely that sanitary conditions were any better.

5. C.S.O. 8/23/205; A.D.B. v.2, p.297-8 Officer was appointed in June 1841 .

6. The most important report was Edwin Chadwick's Report on the Sanitary Condition of the Labouring Population, 1842, see A.S. Wohl, Endangered Lives : Public Health in Victorian Britain, (London, 1983), p.147-8.

7. R.J. Solomon, Urbanisation: The Evolution of an Australian Capital, (Sydney, 1976), p.58-61 for figures on population growth. 
Despite Hobart's numerous health problems, Officer was optimistic that if the citizens were given "the management of their own civic interests" the nuisances could be overcome. In 1846 a controversial experiment in local self-government was tried in the form of a 'court' of 15 elected commissioners, whose responsibilities included the water supply and paving and cleaning the streets of Hobart but this had collapsed within a year. 8 It was not until 1852, after a period of bitter debate, that municipal government was established in Hobart and Launceston and seven member elected councils were formed. To be eligible to become an alderman possession of real estate valued at least at $£ 500$ or rated at an annual value of $£ 50$ was needed and plural voting was introduced by the Hobart Town and Launceston Municipal Councils Act. Thus from the start property owners assumed a dominant position. In the first year both Councils passed by-laws regulating the accumulation of filth and the removal of night soil. 9 After responsible government was granted in 1856 the two municipal councils were incorporated and their constitutions and powers newly defined by the Hobart Town Corporation Act 1857 and the Launceston Corporation Act 1858. Aldermen were increased to nine and they elected one of their number to be Mayor. Property restrictions were retained and strengthened. Other legislation referring to sanitary matters was passed. The Hobart Town Improvement Act 1857 and the Launceston Improvement Act 1858 empowered the two councils to pave, cleanse and drain their cities and to appoint

8. M. Roe, "The Establishment of Local Self-Government in Hobart and Launceston, 1845-1858", T.H.R.A., v.14, No. 1, 1966, p.21-43 for what follows.

9. For Launceston see Hobart Town Gazette 29 March 1853, p.245-6 and for Hobart see Hobart Town Gazette 11 October 1853, p.911-16. 
a City Surveyor and an Officer of Health. These Acts were later repealed by the more extensive Police Act 1865, which empowered municipal councils to control all matters concerning "the health and comfort" of their residents.

Although the depression experienced by the Tasmanian economy in the period 1858-72 probably circumscribed what could be achieved by the two Councils some improvements were made. 10 In Launceston, where the population reached 10,668 in 1870 , the Corporation's record was more noteworthy. By 1857 a magnificent new town waterworks had been completed. $^{11}$ In 1860 the sewering of the town was commenced and gradually extended. ${ }^{12}$ The growing importance of sanitation was indicated by the formation of a Health committee of three aldermen in December 1868. ${ }^{13}$ In June 1869 aldermen were perturbed by the increasing incidence of typhoid. ${ }^{14}$ After seeking the views of doctors, who blamed typhoid on the filth of the town, aldermen decided to replace the part-time officer who inspected nuisances with a full-time Inspector of Nuisances. ${ }^{15}$ In August Robert Ure was appointed with power to clean up the town. ${ }^{16}$ Also in 1869 a more stringent Building Act was passed: in 1874 the Launceston Noxious Trades Act regulated "such unwholesome occupations as soap-making, bone-boiling, fell-mongering etc."17

10. W.A. Townsley, "Tasmania and the Great Economic Depression, 1858-72", T.H.R.A., v.4, 1960, p.35-46.

11. Cyclopedia of Tasmania, (Hobart, 1900), v.2, p.26-9.

12. Ex. 1 January 1861; Launceston Sewerage Act No. 31875.

13. Ex. 15 December 1868.

14. Ibid 15 June 1869 .

15. Ibid 20, 27 July 1869.

16. Ibid 17,31 August 1869.

17. K.R. von Stieglitz, A History of Local Government in Tasmania, (Launceston, 1958), Chapter 15; M. 12 September 1874. 
In Hobart, where the population had crept to just over 19,000 by 1870 , the city waterworks was not opened until 1861.18 Sewering the city was considered but not attempted, mainly because of the cost. ${ }^{19}$ A City Inspector was first appointed in 1853 and from 1858 was assisted by the police: the longest serving City Inspector before 1900 was William Mason, who began work in $1868 .{ }^{20}$ A Health committee was appointed in January 1867.21 It gave early attention to the Hobart Rivulet, which being "a common sewer and depository of rubbish etc.... must in hot, dry weather be the source of deleterious exhalations conducive to sickness", but met with little success in improving its terrible state. ${ }^{22}$ A limited Hobart Building Act was passed in $1858 .^{23}$ Parliament also assisted in improving sanitary conditions by passing the Cemeteries Amendment Act 1870, whereby once the Hobart Town Public Cemetery was opened at Cornelian Bay, about three miles from the Hobart Post Office, as it was in October 1872, other burial grounds of various religious denominations within the city were closed. 24 Thus some of the evils to which Officer had referred were tackled. According to Dr. Edward Swarbreck Hall the measures taken by the two Councils had a beneficial affect on the public health.

18. Townsley, op.cit., p.36; Cyclopedia of Tasmania, op.cit., v.1, p.185-7.

19. MCC $16 / 129 / \mathrm{p} \cdot 587-97$.

20. Ibid 16/129/1 and 3; Walch's Tasmanian Almanac 1868, p.140.

21. M. 15 January 1867.

22. Ibid 11, 25 June, 20 August, 8 October 1867.

23. von Stieglitz, op.cit., Chapter 14.

24. L.C.P. $1876 / 30$. 


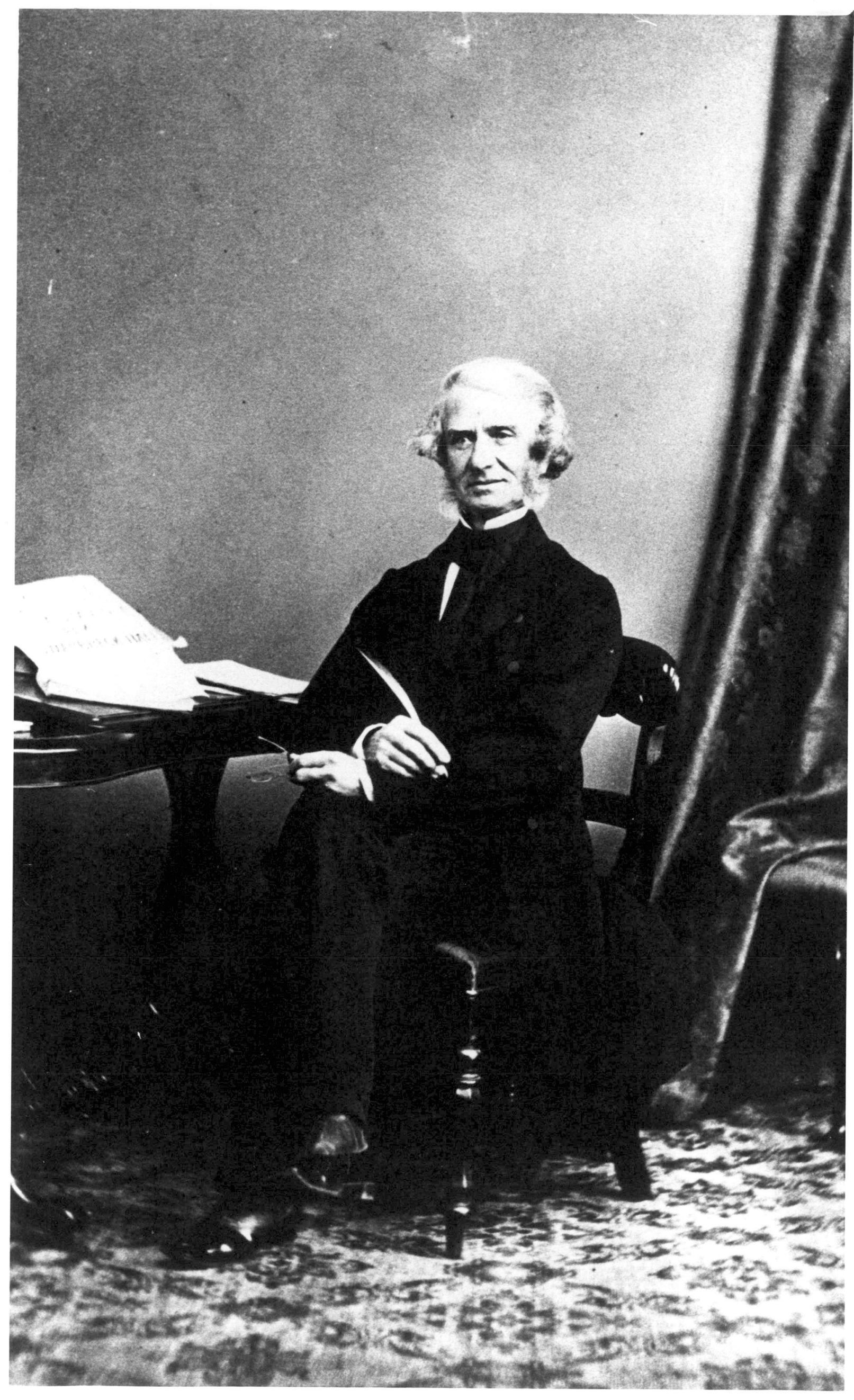

DR. EDWARD SWARBRECK HALL 
Born in England in 1805, Hall trained as a doctor in Dublin and London and was a member of the Royal College of Surgeons. ${ }^{25}$ After arriving in Tasmania in 1832, he held various medical positions in public institutions throughout the island before settling in Hobart in 1853. From the mid-1850s he was the loudest and most persistent advocate of public health reform, writing articles in the Tasmanian Daily News and later the Mercury. From $1856 \mathrm{Ha} 11$, who was a member of the Epidemiology Society of London, provided monthly reports on the health of Hobart giving the types of diseases that had occurred, the causes and the number of deaths. In 1872, from statistical tables he had compiled between 1857-71, Hall concluded that there was "undoubted statistical evidence that the deaths in Tasmania have been undergoing a great reduction of late years, ...."26 The trend was evident in Hobart and Launceston and Hall believed that the improved water supply "contributed considerably to this gratifying diminuition of the death-rate" by reducing in particular the incidence of bowel disease. 'Important too was the increasing proportion of the native born population over that of immigrants and "the dying off, and emigration from the Island, of imported adults of originally depraved constitutions". But, referring mainly to Hobart, the failure to to remove decomposed animal and vegetable refuse, rarely emptied

25. E.F. Haynes, "Edward Swarbreck Ha1l: Medical Scientist and Social Reformer in Colonial Tasmania", unpublished M.A. Thesis, University of Tasmania, 1976, p.119ff.

26. E.S. Hall, "Climate and Vital Statistics in Tasmania", in E.S. Hall and F. Abbott, Results of Five Years' Meteorological Observations for Hobart Town; .... And Completing a Period of Thirty Years, (Hobart Town, 1872), p.9-37. Hall first observed a trend towards a reduction in the death rate in 1865 see E.S. Hall, "Summary of Weather and Health in 1865", P.P.R.S.T., 1865, p.132-4. 
privy cesspools and poorly constructed drains showed, wrote Hall, that "man's care has so far done little to obviate those hygienic drawbacks which the concentration of a city population will always produce, whatever may be the climatic and local advantages, unless special care be taken".

The force of Hall's words was alarmingly driven home in early 1875 with the appearance of epidemics of measles and typhoid, which acted as a spur to reform. Concerned at the deaths caused by the epidemics the Colonial Secretary Thomas Chapman asked the port health officers of Hobart, Dr. George Turnley, and of Launceston, Dr. John Miller, to report on the sanitary conditions of their respective cities. 27 Chapman wanted to know whether the conditions were "such as to account in any measure for the increased amount of sickness lately prevalent" and what remedial steps were required "to more effectually protect the public health". This looked to be a breakthrough for public health reformers - a Government commissioned report on the sanitary condition of the two main urban centres by well-qualified and respected doctors. 28

Turnley replied on 23 June. At the time he was preoccupied with the large number of admissions, occasioned by the epidemics, to the Hobart General Hospital, of which he was Surgeon Superintendent. To provide a reliable and thorough report, Turnley wrote, would require a more lengthy investigation than he had time to undertake and also the power to enter dwellings, which he did not have. He pointed out that Tasmania stood "almost alone as a British Colony in having no legislative enactments nor any

27. H.A.P. $1875 / 93$.

28. For the careers of Turnley and Miller see C. Craig, Launceston General Hospital - First Hundred Years, 1863-1963, (Launceston, 1963), p.25-6. 
organization for the protection of the Public Health"; except for quarantine regulations. There was a need, he urged, for a Department of Public Health to be established and to carry out constant investigations of the sanitary condition of Tasmanian towns. Miller's report was more specifically related to Launceston. He observed that from 1870 to 1874 there had been an increase of 20 percent in Launceston's death rate, which, by 1874 , had reached 24.10 per 1000. This increase, he thought, was mainly due to a greater incidence of zymotic diseases, particularly typhoid, diphtheria and erysipelas. Miller believed that

Were a complete system of underground drainage carried out in Launceston, and were the emptying of cesspools and dung-pits - where such existed and the cleansing of cowyards and other places enforced under strict official inspection, much would be done towards improving the public health.

These reports and the general sickness convinced Chapman that reform was needed. On 23 July he wrote to the Mayors of Hobart and Launceston pointing out the recent increased mortality and asking them to follow the sanitary precautions set down in the Police Act 1865. They should immediately implement sanitary improvements such as "a better system of drainage and a more frequent inspection of premises likely from their situation and condition to propagate infectious or contagious disease". In Par1iament there was call by Dr. William Crowther that Health Officers be appointed for Hobart and Launceston. ${ }^{29}$ Thus the epidemics had triggered new interest in public health. How did the two Councils respond?

29. M. 27 August 1875 . 


\section{Launceston}

The Launceston Corporation's response to Miller's report was negligible. Aldermen cursorily discussed it and the appointment of a Health Officer was raised but no attempt was made to extend sanitary arrangements. 30 The Examiner, however, began to push for sanitary reform and highlighted abuses and neglect. 31 In January 1879 it argued that reliance on an Inspector of Nuisances to search out sources of disease, after "many years experience", had proved to be "utterly useless". 32 It was time for a Health Officer with "a practical and thorough knowledge of chemistry and medicine" to be appointed." In February 1879 Alderman John Drysdale moved that the Council appoint a Health officer. ${ }^{33}$ He referred to offensive smells emanating from defective drainage, especially in Margaret Street, of which the Council had received many complaints. Opponents of the motion argued that Launceston was too small to warrant the appointment of a Health Officer and the Council could not afford to pay his salary. The Examiner and from 1882 the Daily Telegraph kept sanitary issues before the public in editorials and articles.

In early 1883 the increased incidence of typhoid forced the Council to review its sanitary administration. On 9 April Alderman Henry Button, co-proprietor of the Examiner, who had a special interest in public health, moved that "a Health Officer be appointed to promote the sanitary condition of the town". 34

30. Ex. 16 November 1875 .

31. Ibid 11, 25 May, 5, 9 September 1876.

32. Ibid 18 January 1879.

33. Ibid 18 February 1879.

34. Ibid 10 April 1883; H. Button, Flotsam and Jetsam: Floating Fragments of Life in England and Tasmania, an Autobiographical Sketch, (Launceston, 1909), p.329 for his interest in health. 
Aldermen agreed that some action was necessary. Adye Douglas thought some parts of Launceston were "in a disgraceful condition" and moved as an amendment that "the Council, without at present binding itself to the appointment of a health officer, is of opinion that enquiries should be made by the Sewerage committee as to the health of the town and the propriety of appointing such an officer". Button withdrew his motion and the amendment was passed. The Examiner contended that the enquiry was timely because typhoid was

due to foul drains and sewers, filthy gutters, heaps of rotting rubbish, dirty backyards, and disregard of sanitary precautions, all these things sweltering and festering in the warm sun day after day, and month after month, becoming so many hotbeds of disease and disseminators of fever germs. 35

The Council had been "repeatedly warned" by doctors and others that sanitary reform was required but nothing was done. The Examiner continued: "As buildings increase and open spaces become less, as grass and trees give place to bricks and mortar, the danger arising from the evils we have referred to must also increase rapidly". The Daily Telegraph thought that "In few towns of similar size .... are the rudimentary laws of hygiene more absolutely disregarded than in Launceston". 36 At present "no insurmountable difficulties" were in the way of sanitary reform but further delay would make it "terribly arduous".

By October the report of the Sewerage committee had been completed. ${ }^{37}$ It was a remarkable document. Seven doctors and John

35. Ex, 7 May 1883.

36. D.T. 27 June 1883.

37. Ex. 2, 13 October 1883 . 
Bushman, a veterinary surgeon with experience in sanitation, were sent a printed copy of 18 questions: nine questions were directly related to the outbreak of typhoid and the other nine broached subjects such as housing of workers; the need for a Health Officer and the condition of lodging houses. (Appendix A) Evidence was also obtained from heads of Corporation departments and the City Missionary. The Sewerage committee concluded that all the Australian colonies were experiencing a wave of typhoid and

in the first instance the germs of the disease were introduced here; but their subsequent continuance, multiplication and spread are unhesitatingly ascribed to imperfect drainage and disregard of the laws of health. Accumulations of ordinary house rubbish and filth of various kinds appear to be common, while stagnant pools are of frequent occurrence.

By removing filth, disease "might be greatly diminished, if not completely eradicated". This would be achieved by appointing "a properly qualified officer" to inspect houses "and insist upon proper drainage and the removal of all objectionable matter". The appointment of a doctor was not necessary. A doctor would require a salary beyond the means of the Council. The report also opposed a part-time Health Officer on a reduced salary because "it would not be desirable, even if it should be found practicable, to combine the duties of public Health Officer with those of private practice". All that was needed, recommended the Sewerage committee, was "An intelligent and energetic man, possessing firmness and forebearance", who should be immediately appointed. 
The report recommended the "immediate suppression" of cesspits, which were hardly ever emptied: in one case a witness stated a pit had not been emptied for over 20 years. Opinions on the use of dry earth closets diverged but the weight of evidence was against their use. Confining dry earth closets to the low-1ying parts of the town, particularly the Swamp, under the management of the Council was suggested because of the difficulty of draining these areas. Provision for refuse removal by the Council was imperative. Evidence concerning the housing of industrial classes was "somewhat meagre". Instances of overcrowding were cited and it was claimed that houses often lacked a sufficient number of bedrooms. Common lodging houses required "much closer supervision than at present exists". Witnesses were unanimous that the Swamp. area, to the north of Launceston, was the source of much of the typhoid and diphtheria. Originally land alienated by the Crown, the area had been "subdivided again and again" leading to "the erection of cheap cottages by labouring men, the result being that a locality quite unfit for human dwellings is being rapidly covered with them". It was "strongly" recommended that "application be made to the Government to prevent the possibility of any further part being alienated and so aggravating the evil that now exists". Sewage discharge into the river was described as "highly objectionable" and would be exacerbated as the use of water closets increased but until an alternative was found, the Sewerage committee was "unable to see how it may be prevented". Cemeteries should be closed and a public cemetery established "a few miles from the town on the line of the Launceston and Western Railway". The water supply was "as pure as it is copious", only requiring filtering beds at Distillery Creek dam. Finally it was though that 
the carrying on of noxious trades within two miles of the town boundary should be prohibited after $\quad 31$ December 1888.

Although aldermen had minor objections to parts of the report, it was adopted on 8 October and it was decided to call for applications for the position of Sanitary Officer at a salary of $£ 250$ per annum. 38 From the 36 applicants John George Bushman was appointed. 39 Born in Germany in about 1834, Bushman trained as a veterinary surgeon before entering the army and served in India. Retiring from the army on half pay in late 1879, Bushman arrived in Tasmania with his family in early 1883. He was a tireless and dedicated worker and by April 1884 had inspected 600 premises, noting particularly accumulations of sewage and refuse, and issued 71 notices. 40 He recommended that the Council removeall sewage and refuse and that five acres of land be rented at Newstead at $£ 20$ per year for two years on which to deposit it. The cost of removal, including carts and horses, would be $\$ 445 .^{41}$ Aldermen were divided on the recommendations. ${ }^{42}$ Adye Douglas pointed out that the sewerage system was slowly being extended over the city but until it was completed the Council had to provide for those areas of the town not yet served. Accumulations of nightsoil and refuse were threats to health and it was cheaper to pay a $4 d$. rate than for each individual to have the rubbish removed, as was shown by the Corporations of London and Glasgow. To those with sewers who objected to paying rates for services that would not benefit them Henry Button argued that "If fever originated in the lowest parts of town, in a few days they heard of it being on the tops of the hills.

38. Ex. 9 October 1883.

39. Ibid 13 November 1883, 17 March 1904.

40. Ibid 2 April 1884.

41. D.T. 20 May 1884.

42. Ex. 27 May 1884. 
Looking at it from that point of view, everyone was on the same platform". Alderman Robert Carter added that "as the health of the town increased, so would the value of property increase". Other aldermen opposed the expense of Bushman's proposals and decision was postponed.

Ratepayers also opposed the proposals. On 30 June 160 ratepayers petitioned the Council against the "impolitic" scheme because the increase in rates "would be ruinous to the owners of property and ratepayers" and would "cause disaffection between them and your worshipful Council". 43 Further, "the health of the town of Launceston does not require the services of the socalled Sanitary Officer, neither has it improved under his management". The Inspector of Nuisances had kept the town in a cleaner condition than Bushman and "at a less cost". A report by the Sewerage committee stated that the removal of nightsoil and refuse could be done "most efficiently and economically by workmen directly responsible to the Council". 44 It was recommended that the cost of emptying cesspools be 20s. and the removal of . rubbish 3s. per load. The use of cesspits should be prohibited and replaced by water closets: where land was less than one foot above high water mark the pan system would be allowed, with pans provided by the Council and emptied at least twice weekly by the scavenging staff. The report was adopted, thereby vindicating Bushman. 45

In his first half yearly report Bushman pointed out further sanitary deficıencies. ${ }^{46}$ Ventilation of main sewers was entirely

43. Ibid 1 July 1884 .

44. Ibid 8 July 1884 .

45. Ibid $15 \mathrm{July} 1884$.

46. Ibid 22 July 1884. 
neglected, "although it is of great sanitary importance, and all intelligent sanitarians know that any system of sewerage without thorough ventilation is a fruitful source of disease". The cost of water closets hindered their wider use. Most homes had waterwashed pits, that is "pits flushed with water and connected with the sewers by untrapped and badly laid drains. This is, to my mind, the greatest prevailing evil and should be abolished without delay with the cesspits". Refuse was placed in holes in the ground "to do away with the necessity of having it removed": Bushman insisted upon the use of small refuse receptacles "so as to necessitate frequency of removal". Bushman's inspection of cowkeepers, dairymen and purveyors of milk, bakehouses, butchers, common lodging houses and schools exposed widespread neglect of sanitary principles that could be corrected by closer supervision. In general, Bushman wrote, the health of the town depended "to a very great extent on systematic inspection".

Bushman's ubiquity was not appreciated by an increasing number of ratepayers. In September 500 freeholders and householders sought his dismissal. 47 Alderman Ellis continued the attack by asking the Council to give Bushman three months notice from the end of 1884 . $^{48}$ Ellis claimed that "nine-tenths of the burgesses of Launceston" thought that the Council could not afford a Sanitary officer and that the money would be better spent on streets and paths. Alderman B.P. Farrelly seconded the motion. He had received an unsigned letter saying that his election would be jeopardised if he did not support the motion but, after much thought, he had decided to vote against it. Farrelly had read

47. Ibid 16 September 1884.

48. Ibid. 
"some of the very highest" authorities on sanitary reform and was convinced that Bushman was ridding Launceston of the sources of typhoid: as a newcomer Bushman made "no distinction of persons, no difference between rich and poor". Alderman S.J. Sutton claimed Bushman's "manner and mode of doing things was very objectionable" and gave the Council "a very large amount of difficulty in carrying out sanitary reform". Henry Button held ambivalent views. He acknowledged Bushman's success in exposing "a large amount of filth" and his work was of "a very practical character". Half the names on the June petition critical of Bushman were those against whom he had been "compelled to take action, or had threatened to summons". The main objection to Bushman seemed to be, continued Button, that he wore gloves and carried a cane. A Sanitary Officer needed "a large degree of suavity of manner, tact and patience", qualities that Bushman lacked. Button had voted against Bushman at every ballot, feeling that his training at a military school in India did not fit him for the job. The motion was defeated, only Ellis and Sutton voting for it. In December, at a public meeting of aldermanic candidates, the majority announced opposition to Bushman and said only an Inspector of Nuisances was required. 49 Newspapers were replete with letters which "unsparingly heaped their abuse" on Bushman. 50 This was the first election that Bushman came under attack but it was not the last. The reservoir of abuse remained full in subsequent years. Two candidates who were critical of Bushman, Peter Barrett and H.J. Dean, were elected: Dean tried to have Bushman dismissed but failed. 51

49. Ibid 2 December 1884.

50. D.T. 22 December 1884 letter by Justice.

51. Ex. 12, 23 December 1884. 
In 1885 the Launceston Corporation assumed greater responsibility for public health than ever before mainly because Button was Mayor and other aldermen, including Carter, Farrelly and David Scott, regarded sanitation as the most important function of the Council. In March it was decided to prohibit the use of cesspits from 1 July 1885 and allow nothing except water closets and pans approved by the Corporation. 52 In 1883, using powers granted by the Police Amendment Act 1881 and with the appointment of a new City Surveyor, Edward Fitzherbert, the Council started to give attention to insanitary housing and in 1885 even more decisive steps were taken. 53 In his valedictory address Button wrote that "After repeated but ineffectual warnings to the owners for two or three years past" the Council demolished 27 "dilapidated buildings which have so long disfigured and jeopardised the health of the town". 54 Some demolished houses had been "immediately replaced by a new one and this will ultimately follow in every instance": other houses "in bad condition have been thoroughly repaired and renovated to avert an order of demolition". By December 1885 the Corporation emptied 980 cesspits and collected 2543 tons of excreta. 55 Also 1275 premises were cleaned. Button claimed that the collection "of such a mass of pestilential matter" resulted in the decrease of deaths from diphtheria and typhoid, "those fell diseases which have their origin exclusively in filth". He noticed that

52. Ibid 17 February, 4 March 1885.

53. Ibid 9 January, 22, 29 May 1883, 26 August 1884.

54. Ibid 8 December 1885.

55. Ibid. 
an air of cleanliness and comfort now pervades the lowliest homes which has an elevating social tendency. Vegetables, and even flowers, may now be found occupying corners where before heaps of filth and pools of stagnant water polluted the air.

Finally "the irritation which immediately followed the appointment of the Sanitary Officer has greatly diminished and that instead of being looked upon with aversion he is now willing1y aided in the discharge of his duties". That this was not quite true will be shown in later chapters but it was clear that sanitary administration in Launceston had improved by 1885 .

\section{Hobart}

Measures to improve the public health were discussed by the Hobart Corporation on 13 September $1875 .^{56}$ Alderman Walch, chairman of the previously dormant Health committee, pointed out that there had been no necessity for a Health Officer in the past but now that Hobart was "getting a good old age" and there were "many accumulations of sewage", the position had changed. Alder- . men agreed in principle that Hobart needed a Health Officer but that the details of, for example, payment had to be worked out in conjunction with the Colonial Secretary. The Mercury seized upon this opportunity and pushed for the appointment of Dr. E.S. Hall, whose devotion to the study of vital statistics and the sanitary condition of the city, "in the face of much discouragement and public ingratitude", deserved to be rewarded. 57 Con-

56 M. 14 September 1875 .

57. Ibid 8 November 1875; see also T.T. 9 November 1875. 
tinued indifference to the public health by the Council, the paper argued, would not only result in more deaths but "the loss to the city of that character for salubrity, which has done so much to attract strangers and to add to the trade of the city". The Mercury questioned the past reliance on the city's climate. Hobart was the healthiest city "under the sun" but

$$
\begin{aligned}
& \text { instead of private individuals and public bodies } \\
& \text { exercising ordinary care so as to preserve our } \\
& \text { blessings, and not taint our otherwise pure atmos- } \\
& \text { phere, there has been a general disregard for all } \\
& \text { precautionary practices; and like a young man pre- } \\
& \text { suming on the strength of his constitution till } \\
& \text { excess leaves him a wreck, the people of Hobart } \\
& \text { Town have gone on defying all sanitary laws, over- } \\
& \text { straining the purity of the atmosphere, and leaving } \\
& \text { the streets of the city and places out of sight a } \\
& \text { putrefying mass of animal, vegetable and aqueous } \\
& \text { matter. }
\end{aligned}
$$

The editors of the paper carried out their own survey of the city and found numerous sources of disease in rich as well as poor localities. There was, they concluded, an indisputable need for a Health Officer. On 9 November Chapman notified the Hobart Corporation that the Government was prepared to contribute $£ 100$ per annum towards the salary of a Health Officer for Hobart and adjoining towns and favoured the appointment of Hall. ${ }^{59}$ The proposal was referred to the Health committee, which, on 15 November, recommended that Hall be appointed Health Officer at a salary of $£ 150$ per

58. Ibid 15 November 1875.

59. Ibid 10 November 1875. 
annum, subject to "such rules and regulations" as the Council might deem necessary. 60 There was no opposition to Hall's appointment but a motion by Alderman Brownell to reduce his salary to $\$ 100$ was passed.

The appointment of a Health Officer was an important milestone in the sanitary management of Hobart and Hall soon started work. He carried out a comprehensive examination of the city, giving particular attention to the area in Lower Collins Street known as Wapping where about 600 poor people lived. 61 He spent six to nine hours a day making house to house visits, which he believed was the only way to ferret out "the numerous seed-beds of disease which exist throughout the city". He described the drains and sewers of the city as "elongated cesspools, incessantly giving off noxious gases to the vitiation of public health and the incubation of disease". There were too few scavengers to keep gutters and drains clean. He found cesspools were hardly ever emptied and advised their abolition. They should be replaced by the dry-earth system with moveable pails or boxes: the deposits should be covered with dry-earth or ashes and frequently emptied. Hall admitted that the dry-earth system was not the best but it was the easiest to implement promptly and the least expensive. He preferred a sewerage system and continually advocated that one be built. The reaction of the Council was disappointing. Alderman Walch said there was "no necessity to take any action on the report" and it was ordered to lie on the table. In December a motion was passed to prevent Hall's reports from being read public1y before they were vetted by the Health committee because "they might frequently be injurious to the best interests of the city"

60. Ibid 16 November 1875 .

61 Ibid 30 November 1875; Haynes, op.cit., p.321-2. 
by driving away tourists. ${ }^{62}$ This motion did not augur we11 for the future of sanitary reform. In February 1876, after considering the failure to implement Hall's recommendations and the censorship of his reports, the Mercury bluntly asked:

If this was not part of a systematic attempt to defeat the purpose of the appointment of a Health Officer; if it did not spring from a desire to avoid giving offence to ratepayers who might retaliate at election time, why have the City Council kept to themselves all knowledge of the Health Officer's reports? 63

Throughout his period as Health Officer, Hall received little support from aldermen and realised that he lacked the legal power to carry out effective sanitary reform without this support. In October 1876 he pointed out that his powers were "much below" those of Health Officers in England and wanted "speedy action" taken to have them enlarged but they were not. ${ }^{64}$ Hall never ceased pointing out the need to abolish cesspits and to replace them with earth-closets or a sewerage system for Hobart and the surrounding suburbs but without success. ${ }^{65}$ His modest achievements should not be ignored. In 1877 he succeeded in securing the appointment of more scavengers to clean the streets but the following year the scavenging staff was cut back. ${ }^{66}$ In 1880 the Council was empowered to borrow money to improve the storage capacity of the water supply and to clean up and permanently improve the Hobart Rivulet, which Hall had advocated. 67 He also brought

62. M. 7 December 1875 .

63. Ibid 12 February 1876.

64. Ibid 14 November 1876; H.A.P. 1878/33.

65. H.A.P. $1878 / 33$.

66. M. $_{\text {. }}, 4,17$ January 1877. T.T. 23 April 1878.

67. L.C.P. 1881/112; H.A.P. 1880/35. 
the milk supply under closer supervision by sending milk samples to the Government Analyst and regularly inspecting dairies and milkshops. 68 In 1880 Hall was thrown from his gig and, being 76 years old, never regained full strength: he died on $30 \mathrm{July}$ 1881.69

In July, during Hall's incapacity, a temporary replacement had to be found, but this was not achieved without opposition. On $18 \mathrm{July}$, at a special meeting to discuss the matter, Alderman Belbin remarked that Hall was only appointed "to a great extent, in recognition of the many services he had rendered and .... it could not be considered as a precedent to follow in the election of another officer even temporarily". 70 This, however, was an isolated view. Applications were called for the position and three were received: Drs. G.H. Butler, E.J. Crouch and E.0. Giblin. 71 Giblin was appointed. A cousin of the Premier, W.R. Giblin, Edward Owen Giblin was born at Claremont, Tasmania in 1849 and received his medical training at the University of Aberdeen. ${ }^{72}$ After graduating in 1878 , he entered private practice in Hobart, and then became an honorary surgeon at the Hobart General Hospital. On 29 August his temporary appointment as Health Officer was made permanent. 73 Like Hall, Giblin stressed in his reports the urgent need to replace cesspits with the pail system and to provide a sewerage system for Hobart and suburbs. ${ }^{74}$ No action was taken

68. M. 11 June 1878, 10 June 1880 .

69. Haynes, op.cit., p.324-6.

70. M. 19 July 1881 .

71. Ibid 26 July 1881 .

72. S. Bennett and B. Bennett, Biographical Register of the Tasmanian Parliament 1851-1960, (Canberra, 1980), p.65.

73. M. 30 August 1881 .

74. H.A.P. $1882 / 30,1883 / 31$. 


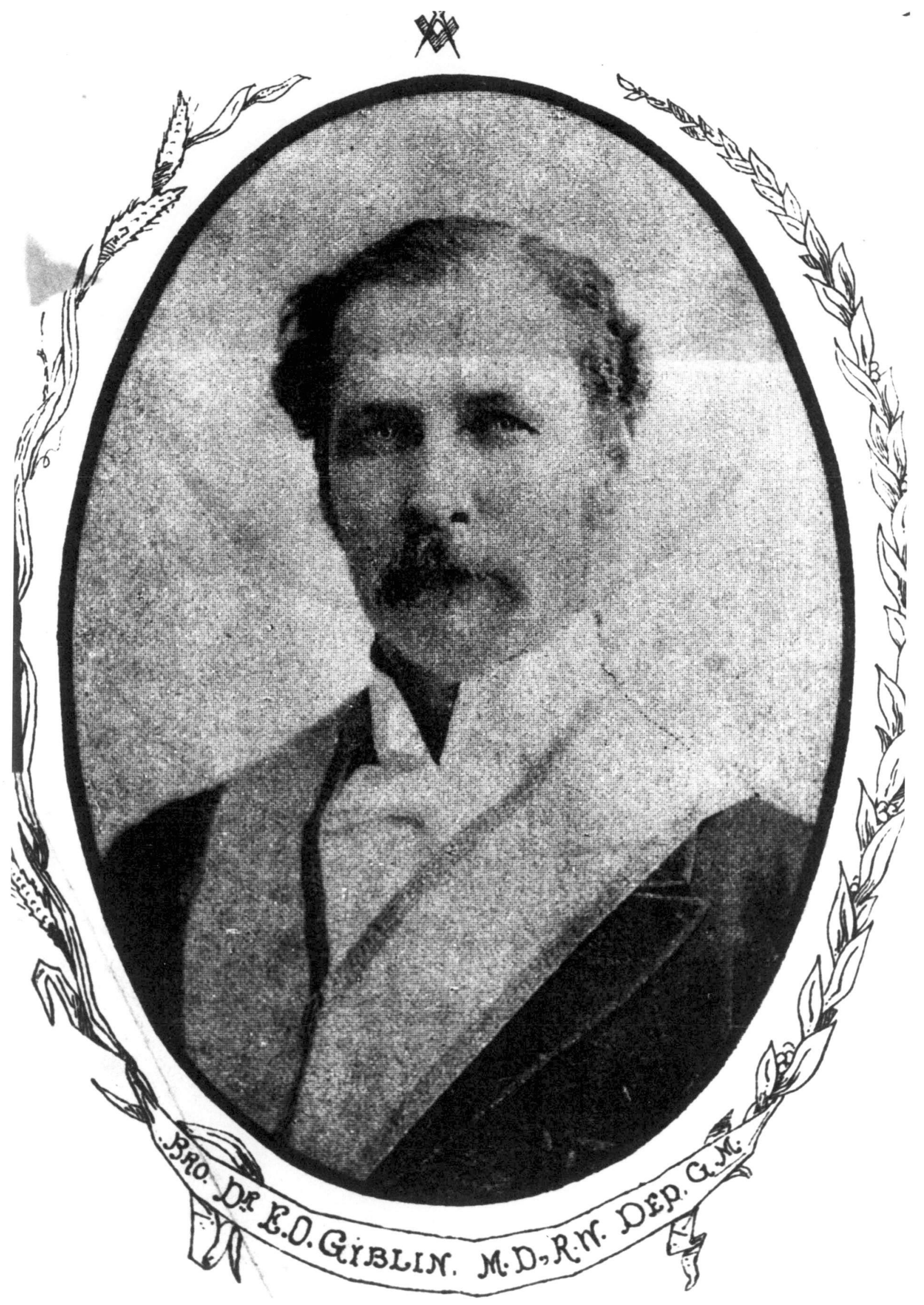


until 1883 when there was an "unusual1y large" number of deaths from zymotic diseases. 75 Giblin feared that deaths from these diseases, especially diarrhoea and typhoid, would climb unless cesspits were abolished. On 5 November 1883, after receiving a special report from Giblin, the Health committee told the Council that "the time had arrived when some active steps should be taken to remedy the insanitary condition of the city, a condition brought about by the large number of cesspits which exist, in a more or less offensive condition". 76 It recommended that the Council undertake the removal of nightsoil, as was done by the Melbourne City Council. In Hobart sewage could be disposed of either by using water closets that emptied into drains or rivulets or by the periodic emptying of pails or boxes but in the large majority of cases, leaking and abominable cesspits are used, whose contents are only removed every few years, the fluid portions percolating the surrounding subsoil for many yards.

Cesspits should be filled in and replaced with galvanised pails. Two sanitary carts should be purchased to assist in "a thorough and periodical" emptying of the pails. Finally the Health committee recommended that two by-laws be passed: one to forbid the construction of new cesspits and the other to empower the Council to levy a rate for emptying pails. Desiring to prevent further outbreaks of zymotic diseasès, aldermen unanimously approved of the proposals and by mid-1884 the new sanitary system had been implemented.

75. Ibid $1884 / 29$.

76. M. 6, 13 November 1883 . 
- Giblin had argued that legislation was needed to make the use of cesspits illegal. On $14 \mathrm{July} 1884$ the Health committee drafted a Bill, which would prohibit the construction of further cesspits; empower the Corporation to close immediately neglected cesspits liable to foster disease and make compulsory the closure of all cesspits by 1 January 1887.77 As insanitary conditions and pigs went hand in hand the Bill would also empower the Council to regulate the keeping of pigs. Receiving no opposition in Parliament the Public Health (Hobart) Bill became law on 24 November 1884.78

By the end of 1884 Giblin claimed that already "many houses, which previously were unwholesome to live in owing to the near presence of a noisome cesspit, are now sweet and healthy". 79 Later Giblin told of one yard where 10 cesspits had been used by about 15 nearby tenements and typhoid appeared regularly: when the cesspits were closed, typhoid was "banished". 80 By 1886 the keeping of pigs was "almost unknown in the city". 81 Giblin also attended to insanitary housing. Under the Police Amendment Act 1881, he wrote in his annual report of 1882, "much good work" was done in improving the state of some dwellings and demolishing others. $^{82}$ However he predicted that the task would occupy much time because

In many houses, ..., there is much room for improvement, and landlords in Hobart are as unwilling as elsewhere to remedy such evils as dampness, bad drains and want of ventilation.

77. Ibid $15 \mathrm{July} 1884$.

78. Ibid 15, 23, 24 October 1884.

79. T.P.P. $1885 / 27$.

80. Ibid $1886 / 28$.

81. Ibid.

82. H.A.P. $1883 / 31$. 
The paving of the Hobart Rivulet and the construction of retaining walls was likewise progressing slowly. ${ }^{83}$ The city slaughteryard, built on land fronting the foreshore of the Derwent, just to the north-east of the Rivulet, also received attention. 84 In June an article published in the Southern Star alleged that the insanitary condition of the slaughteryard would soon cause "some fearful epidemic". 85 The Chief Secretary wrote to the Council asking for a report because if the allegations were true they revealed "a condition of things .... so revolting and unhealthy as to demand immediate and vigorous action". 86 Giblin's report substantially confirmed the allegations and the Chief Secretary demanded that the Council bring the slaughteryard into conformity with those of other cities. The Slaughterhouse committee agreed that the article contained "some truths" but that it had exaggerated. 87 The major problem was defective drainage due to the low level of the yards: the level would have to be raised about four feet to ensure proper drainage. As the site had been chosen and the buildings erected by a previous Government, aldermen argued that the present Government should finance the improvements. The Government predictably refused. Instead minor Improvements, such as enlarging the pigsties and cattle pens and making the water supply more efficient, were carried out by the Council. 88 On the whole, then, the Hobart Corporation, like the Launceston Corpor-

83. TPP 1886728 .

84. The Hobart Corporation took over the slaughteryard from the Government by the Hobart Town Slaughter. Act 1858 TPP $1893 / 75$.

85. S.S. 28 June 1883 the article was written by a reporter from the Federal Australian.

86. M. 31 July 1883; G.S.D. 13/66/1136.

87. M. 31 July 1883.

88. Ibid 25 September 1883. 


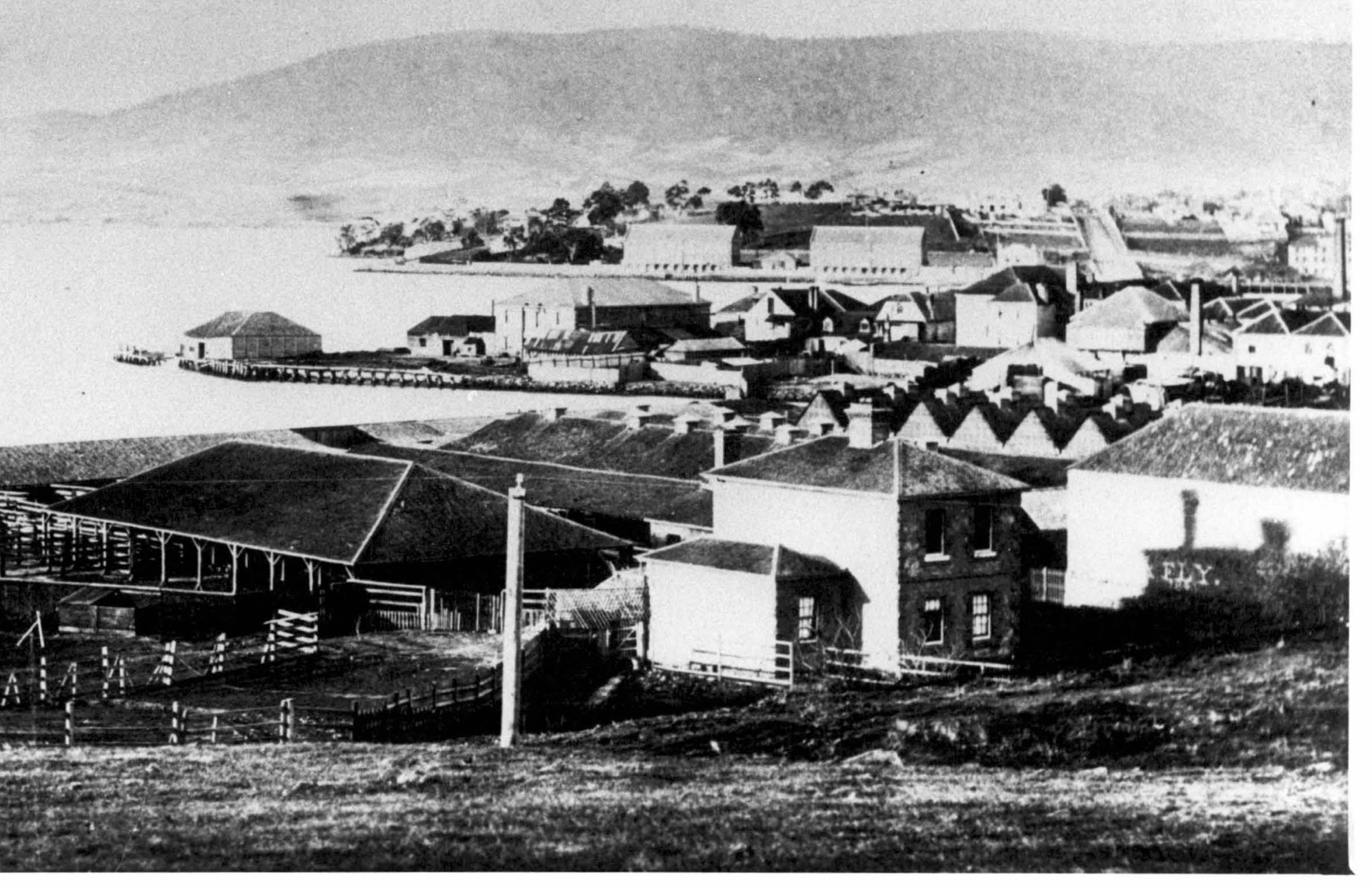


ation, gradually assumed greater responsibility for sanitary administration.

$* * * * * * * * * * *$

Complementing the work of the two Corporations was the progressive social programme formulated by the government of W.R. Giblin. 89 Under Giblin three important statutes relating to public health were enacted. In 1880 the Sale of Food and Drugs Act was passed. 90 It attempted to deal with adulterated food by leaving it to the discretion of municipal councils to either appoint analysts to examine food or, for a fixed fee, to send samples to the Government Analyst. Impure water could spread zymotic diseases and the Rivers Pollution Prevention Act 1881, based on the 1876 British Act, aimed to prevent the pollution of water courses by sawdust, sewers, factories and mining wastes. 91 Finally working conditions were regulated by the Women and Children Employment Act 1884 to ensure sanitary provisions, such as proper ventilation, obtained in factories where women and children were employed. 92 The Superintendent of Police, who was under municipal control, was responsible for its enforcement.

In line with this awakening to the importance of public health was, on 5 August 1885, the introduction of a new Public Health Bill into the Legislative Council by Giblin's successor as Premier Adye Douglas. 93 The Bill was, to a great extent, a consolidation

89. For the Giblin government's achievements see H. Reynolds "The Island Colony, Tasmania: Society and Politics 1880-1900", unpublished M.A. Thesis, Unıversity of Tasmania, 1963, p.I01ff.

90. M. 20, 21 August 1880 .

91. Ibid $28 \mathrm{July}, 12$ October 1881; for British experience of river pollution see Wohl, op.cit., chapter 9.

92. The Bill was originally introduced in 1883 but defeated. M. 9, 16 July, 9, 25 October 1884 .

93. Ibid 6 August 1885. 
of previous Acts and parts of Acts concerning public health.

It was also based on the findings of a Royal Commission in Melbourne and legislation passed in Queensland and New South Wales. It might appear, said Douglas, that particular clauses were "a restriction of public liberty" but they "all knew that it was the duty of all Governments to protect as far as possible the public health". The Bill established a Central Board of Health because it was essential to have "an independent body, apart from the municipal body, who, perhaps, were prevented from taking action br dread of their constituents" as often the interests of ratepayers were "prejudicial to public health". 94 It was imperative, Douglas thought, that sanitary provisions were enforced throughout the colony because many cases of zymotic diseases originated in rural districts where sanitary arrangements were primitive and threatened the advances being made in the two urban centres.

Although Douglas's speech indicated that the new legislation would assist the Hobart and Launceston Corporations, they provided the most serious opposition to it and overreacted to a startling degree. The Launceston Corporation protested against the establishment of a Central Board of Health with power to override local authorities and exercise their functions. 95 To subordinate "a body duly elected by the people to a Board nominated by the Crown" was "a retrograde step subversive of the spirit which animates every British Constitution" and threatened "popular liberty". There was no evidence to suppose that "any Local Board would be

94. Tasmania was the only colony without a Central Board of Health. The other Central Boards were established for Victoria in 1855, Queensland and South Australia 1873, New South Wales 1881 and Western Australia 1884. J.H.L. Cumpston, The Health of the People: A Study in Federation, (Canberra, 1978), p.7.

95. T.P.P. 1885/99. 
less qualified for, or less diligent in, the discharge of the functions assigned to it by law than the Central Board". Thus the Launceston Corporation held the common Victorian attitude of regarding nomineeism and centralisation as anathema. ${ }^{96}$ The Hobart Corporation also opposed the formation of a Central Board. 97

It pointed out that Hobart had a well qualified Health Officer and that the Public Health (Hobart) Act 1884 and the Police Act 1865 "in every way" met the sanitary requirements of the city. This legislation was "faithfully administered" and it was "a great slight" to have a paid Board direct the proceedings of aldermen, who served gratuitously. Municipal opposition was unsuccessful. The Public Health Bill was passed and a Central Board of Health established to supervise all matters connected with public health and to conduct special enquiries where necessary. Municipal councils and Town Boards became Local Boards of Health. If a Local Board failed to enforce the provisions of the Act, the Central Board could order it to do so within a specified period. Further refusal could result in the Central Board appointing a person to carry out the defaulted provision but the reaction of the Hobart and Launceston Corporations was unnecessary. As long as they continued to deal with sanitary problems they did not have to worry about interference by the Central Board. The Public Health Act 1885, and subsequent amendments, strengthened their powers to prevent the sale of adulterated and unwholesome food; to protect infants; to control the spread of infectious diseases by, for Instance, isolating houses; to regulate noxious trades; to

96. For a convenient discussion of the issues surrounding the growth of centralisation see 0 . MacDonagh, Early Victorian Government 1830-1870, (London, 1977), Chapter 1.

97. TPP 1885/99. 
condemn houses unfit for human habitation and to eliminate overcrowding; and to generally rid the environment of disease causing impurities. 98 Centralisation had been introduced but it was at the local level that the success or failure of sanitary legislation would be determined. ${ }^{99}$ Running parallel with the tendency to accumulate power at the centre was a strong desire to further enlarge the scope of municipal government in general and sanitary administration in particular, as the laissez-fair philosophy, dominant at a11 tiers of government in the nineteenth century, was gradually being eroded. 100 This desire first manifested itself in practical terms in Launceston and it is to the Launceston Corporation that we now turn.

98. Amending legislation included Public Health Acts 1887, 1889 and 1896. The Public Health Act 1903 was the most significant amending statute, not so much in the new powers it embodied, but in replacing the Central Board of Health with a Chief Health Officer.

99. See Wohl, op.cit., Chapter 7 for a neat account of local sanitary administration in Britain.

100. See Reynolds, "The Island Colony", op.cit., p.72 who writes of liberals who "committed themselves to an unprecedented use of state power to ameliorate social conditions". 


\title{
PART 2
}

\section{LAUNCESTON $1886-1914$}

"future historians would have to give a prominent place to Launceston when writing up the progress of the Commonwealth".

\author{
Alderman R.J. Sadler \\ D.T. 20 February 1906.
}

Should a gentleman desire to reside in Launceston and to build, the Corporation will supply the building stone, execute the sewering and sanitary work, cement the pathways, asphalt the tennis court, lay on and supply the house with water, instal and supply it with electric current to light the rooms, heat the radiators and clothes iron, and work the sewing machine and lift. His children can be educated at the State Schools, of which the members of the Council form the Board of Advice. They can learn to swim in the Corporation Baths, while those desiring it may enjoy a Turkish Bath in the same building. The Corporation Museum and Art Gallery are open for their education and pleasure. In the Corporation Reserves, Parks, and Cliff Grounds they can take part in games, and enjoy excellent music supplied by Bands subsidised by the Corporation. They can attend Literary and Musical Competitions, and participate in Tourist Drives organised by the Tourist Association, both similarly assisted. They can travel about the City in the Corporation's up-to-date Electric Tramways. He will have the satisfaction of knowing that the Public Health and Sale of Food and Drugs Acts are administered by the Council, and that the Corporation owns and controls the only Abattoirs and Fish Market in the City. If unfortunately his house catches fire a municipally subsidised Fire Brigade, in whose management. the Council participates, will hasten to stay the conflagration: Should illness overtake him he can be treated at the General Hospital, on whose Board of Management the Council is represented, and finally when he "rests with the blest", he will have the solace of knowing that his body will be interred in the Corporation Cemetery.

Launceston's brand of 'cradle to grave' municipal socialism City of Launceston Tasmania 1915 (Launceston, 1915), p.67. 


\section{CHAPTER 2}

\section{"THE BEST GOVERNED CITY" IN AUSTRALIA}

In the nineteenth century rapid industrialization and large concentrations of people in cities created severe strains for municipal government in Britain. Services provided by Corporations were reassessed. Civic reformers sought to make existing services more efficient and to extend municipal involvement into other spheres of activity. This could result in Corporations taking over private enterprises or establishing amenities where private companies had failed to do so. Municipal intervention began in the 1840s and by the 1880 s, financed by large borrowing, a coherent programme had emerged. ${ }^{1}$

The nature of municipal ownership was debated by contemporaries and Kellett has discerned three descriptions: municipal socialism, municipal enterprise and municipal trading. ${ }^{2}$ Municipal socialism, "the most emotionally loaded of the three terms", was first used in the 1880s and by 1902 had been "fully elaborated and publicized" due to the enthusiasm of Fabian socialists, such as John Burns and Sidney Webb. ${ }^{3}$ Municipal socialism included charging rates in such a way that wealthier suburbs subsidised public works in poorer suburbs; the municipalisation of water, gas, trams and markets; municipal housing schemes; and municipal control of the docks. Much of what the Fabians advocated had already been

1. M.E. Falkus, "The Development of Municipal Trading in the Nineteenth Century", Business History, v.19, 1977, p.137.

2. J.R. Kellett, "Municipal Socialism, Enterprise and Trading in the Victorian City", Urban History Yearbook, 1978, p.3645.

3. Ibid, p.38. 
achieved by Corporations throughout Britain and they were influenced by Radical Liberal theoreticians like J.B. Firth and Joseph Chamberlain. ${ }^{4}$ Municipal socialism was a captivating phrase that could win votes at municipal elections but, because of its ideological overtones, opponents could claim that it was the beginning of serious threat to the existing social order. It is true, however, that Fabians differed from other municipal enthusiasts only by their "ultimate objectives" and not their "practical proposals" or "immediate demands."

Municipal enterprise was a "politically neutral" term. 5 In essence it referred to any task that it was essential for Corporations to take on to ensure the comfort, security and especially the health of city residents. Environmental deterioration resulting in epidemics demanded attention. Private bodies were not suited or saw themselves as having no role to play in this area. Municipal councils were given the responsibility or sought the task of fighting the epidemics and, by various sanitary and improvement schemes, ensuring they did not recur. ${ }^{6}$ People gradually grew accustomed to municipal intervention, although not always without a struggle, and this paved the way for other kinds of intervention. ${ }^{7}$ Three phases of municipal enterprise

4. A.M. McBriar, Fabian Socialism and English Politics 1884-1918, (Cambridge, 1966), p.191-4.

5. Kellett, op.cit., p.40.

6. Ibid; A. Sutcliffe, "The Growth of Public Intervention in the British Urban Environment During the Nineteenth Century: A Structural Approach" in J.H. Johnson and C.G. Pooley (eds.), The Structure of Nineteenth Century Cities, (London, 1982), p.107-21.

7. D. Fraser, Power and Authority in the Victorian City, (Oxford, 1979), p. 168 writes that "It was in the very nature of the environmental problems that the attempt at their solution would draw councils further along the collectivist road". 
have been suggested. The first included tasks that were indisputably part of a Corporation's work, including control of the poor, the police, roads, lighting, drainage, scavenging, asylums and infectious diseases hospitals. The second, also fairly noncontroversial, included control of education, libraries, art galleries and parks. The third was controversial, where municipal ownership was not considered to be essential but desirable: water, gas, markets, trams, electricity, piers and harbours were taken over. To a large extent local circumstances (civic pride, expediency, the inefficiency of private companies, or the expectations of ratepayers) determined how many of these functions were absorbed by Corporations. Kellett argues that municipal enterprise was "basically a search for efficiency and economy, unfettered by doctrinaire convictions". 8 The view of Joseph Chamberlain of Birmingham, "the successful businessman, who turned from private enterprise to local and later national politics", became very influential in Britain and overseas. ${ }^{9}$ Chamberlain regarded municipal government as similar to a joint stock company with aldermen as the directors and ratepayers as the shareholders: the dividends were "the improved health and the increase in the comfort and happiness of the community".

Municipal trading developed as a more gradual process than municipal enterprise, which often oscillated between vigorous periods of expansion and economy. Municipal trading, writes Falkus, "grew

8. Kellett, op.cit., p.41.

9. Ibid, p.42; for an example of Chamberlain's influence in Australia see C.T. Stannage, The People of Perth: A Social History of Western Australia's Capital City, (Perth, 1979), p.294; see also an article by H. Button Ex. 22 July 1913. 
haphazardly, largely ungoverned by principle and varied in practice". 10 Kellett thinks that municipal trading developed "its sphere of action by stages which follow an internal logic of their own". 11 Corporations took over public utilities, usually beginning with the water supply, in the belief that collective action would be more efficient and less costly than private action. Success with the water supply not only stimulated confidence in municipalisation but provided the basic element of electric light schemes when this technology was developed and it seemed logical for Councils to provide electric lighting. Whether to either keep the cost of the service low, thereby benefiting consumers, or to charge a high price and use the money for the benefit of ratepayers often created divisions amongst municipal enthusiasts. Kellett placed municipal intervention "against a background of almost constant technology" and Corporations had "the local tax base, borrowing powers and civic bureaucracy" to quickly utilise technological advance. ${ }^{12}$ He concluded that the evolution of municipalisation "was pragmatic and gradual rather than doctrinaire in inspiration". Whatever its dynamic municipalisation did invite a conservative non-interventionist backlash from about 1900 onwards, when it was seen as the thin end of a more fundamental collectivist wedge. 13

10. Falkus, op.cit., p.137.

11. Kellett, op.cit., p.42; also Fraser, op.cit., p.172.

12. Ibid, p.43-4; see Sutcliffe, op.cit., p.110-14 for a discussion of the technological explanation in relation to what he calls the structural explanation.

13. For a good account of this backlash in London see $\mathrm{K}$. Young, Local Politics and the Rise of Party: The London Municipal Society and the Conservative Intervention in Local Elections 1894-1963, (Leicester, 1975), Chapter 3; Fraser, op.cit., p.170-1. 
The growth of municipalisation in Britain engaged the attention of the Australian colonies. The extent of municipal intervention in Australia varied from city to city but nowhere was it more pronounced than in Launceston. ${ }^{14}$ To explain why this was so and to explore aspects of municipal reform in Launceston is the aim of this chapter in order to provide the context in which sanitary measures were considered. First the factors leading to Launceston's rise to prominence as a city rivalling Hobart in importance will be noted. Launceston benefited more than Hobart from the boom period of the Tasmanian economy, which began about 1870.15 In 1885, speaking in the House of Assembly to a Launceston Loans Bill, the Attorney-General John Dodds remarked on the increased trade of the town and added that "altogether the town, during the last ten years, had materially improved" and he congratulated his "enterprising fellow-colonists". 16 Crucial to Launceston's economic growth was its geographical position. It was closer to the mining centres than Hobart and many new mining companies "were floated and directed in Launceston and a large proportion" of shareholders were Launcestonians or resided in the district. 17 Launceston was "a major supply base for the mines" and "a social.

14. For a useful survey of the functions carried out by municipal governments in Australian capital citıes see T.G. Ellery, "Municipal Government in Australasia", Municipal Affairs (New York), v.6, 1902, p.44-67. For factual data see G.H. Knibbs, Local Government in Australia, (Melbourne, 1919); for the Perth experience see Stannage, op.cit., p.269-300.

15. E.A. Beever, Launceston Bank for Savings 1835-1970: A History of Australia's 01dest Savings Bank, (Melbourne, 1972), p.86-9. Beever provides helpful summaries of Launceston's economic development.

16. M. 18 November 1885.

17. Beever, op.cit., p.87. H. Reynolds, "The Island Colony Tasmania: Society and Politics 1880-1900", unpublished M.A. Thesis, University of Tasmania, 1963, p.44-5. 
centre for miners in search of congenial surroundings to spend their wages". Launceston gained from the railway construction of the 1880s and manufacturing flourished. Population increase was one indication of growth, rising from 10,668 in 1870 to 17,906 by 1891. (Table 1) In the same period building was steady, the annual rateable value of property increasing from $£ 63,078$ to $£ 135,168 .^{18}$ Parliament recognised Launceston's importance when legislation was passed declaring Launceston a city from 1 January 1889. Launceston, where Australia's first Chamber of Commerce was formed in 1849, became known as the commercial capital, if not the actual capital, of Tasmania. 19

TABLE 1 : ESTIMATED POPULATION OF LAUNCESTON

\begin{tabular}{|c|c|c|c|}
\hline Year & City & Suburbs & Tota1 \\
\hline 1881 & 12,752 & - & - \\
1891 & 17,906 & 4,275 & 22,181 \\
1901 & 18,077 & 3,217 & 21,294 \\
1911 & 20,937 & 2,789 & 23,726 \\
1914 & 21,399 & 3,279 & 24,678 \\
\hline
\end{tabular}

Source: Statistics of Tasmania.

Launceston's continued prosperity, halted only briefly by the depression of the $1890 \mathrm{~s}$, was an essential pre-condition to the extension of municipal powers. By 1900 Launceston had established it self as a city with probably the most progressive Corporation in Australia. The Corporation provided an abundant water supply

18. Knibbs, op.cit., p.144-5.

19. Cyclopedia of Tasmania, (Hobart, 1900), v.2, p.16.

20. Ibid, p.82 for what follows; see also survey of the period 1870 to 1895 by the City Treasurer Ex. 11 March 1895 and Ellery, op.cit., p. 55. 
for the city and suburbs, and had built a serviceable drainage system. Miles of well made streets had been constructed and "from its quarries and works supplies stone and metal, and also executes private cementing and asphalting work". It administered the Public Health Act and owned the only slaughteryard in the city. It managed a museum and art gallery; swimming, plunge and Turkish baths; parks and reserves; and had built the Albert Hall, which could seat 3,600 people. 21 In 1895 it was the first Australian Corporation to establish an electric light works. ${ }^{22}$ Corporation employees had a provident fund, which encouraged thrift and "practically establish [ed] the old age pension system": 1oans were provided for employees to build their own homes. The Council controlled the police of the city until centralization was introduced in 1899 and aldermen were members of the Fire Brigade and Hospital Boards: seven aldermen formed the local Board of Advice, under the Education Act. In 1897 the Launceston City and Suburban Improvement Association, which since 1889 had transformed the Cataract Gorge into Launceston's main tourist attraction, became Indebted to the extent that it could not continue. $^{23}$ Negotiations with the Launceston Corporation to take over the Gorge area and to pay off the debt were successful and in March 1898 the Corporation formally assumed control, charging a small fee for admission. Thus even tourism was assisted.

21. The Albert Hall was "claimed to be the eleventh largest hall of its kind in the world" Beever, op.cit., p.88-9.

22. The first British Corporation to do so was that of Bradford, just six years before Launceston Falkus, op.cit., p.157.

23. H. Button, Flotsam and Jetsam: Floating Fragments of Life in England and Tasmania, an Autobiographical Sketch, (Launceston, 1909), p.345-49. 
Two other examples of municipalisation should be mentioned, one a failure and the other a success. Moves were made in 1889 and 1897 to hand over the functions of the Marine Board to the Corporation because, as Alderman S.J. Sutton remarked, "the welfare of the city is bound up more and more in the condition of the port". 24 Although the Marine Board has a low public esteem, the campaign seeking amalgamation was not well organised and in October 1897, when the issue was submitted to a poll of ratepayers, was defeated by 430 votes to $170 .^{25}$ Federation raised the importance of a thriving port and the Launceston Harbour League, with the motto of ONE CITY. ONE PORT. ONE CONTROL., was formed. ${ }^{26}$ It was very soundly organized and published an "excellent" manifesto, which was "concise and easily intelligible" on the advantages of amalgamation. $^{27}$ At another poll in August 1901 the vote was 1767 for and 485 against the change. ${ }^{28}$ A Bill to legalize the amalgamation was passed by the House of Assembly but received little support in the Legislative Council. ${ }^{29}$ The Harbour League continued to urge amalgamation and port improvement. Amalgamation was not secured but in 1914 the Marine Board began major port improvements. 30

Apart from the electric light works, the provision of trams was the other major example of municipalisation. In both cases

24. D.T. 17 October 1889; Ex. 12 January, 19 August 1897. For the early growth of the port see B. Dyster, "The Port of Launceston before 1851", The Great Circle, v.3, No. 2, 1981, p.103-24. For a basic account see R.A. Ferra11, The Story of the Port of Launceston, (Launceston 1983).

25. Ex. 19 October 1897.

26. Ibid 14 June 1901; D.T. 7 August 1901.

27. D.T. 8 August 1901 .

28. Ex. 21 August 1901.

29. D.T. 5 December 1901.

30. Ferrall, op.cit., chapter 10. 
private enterprise was first given the chance to provide these services but failed to raise enough capital. ${ }^{31}$ Reports by experts were prepared and fully debated. Ratepayers were then asked to vote at a poll first to see if they were in favour of embarking on the scheme and second whether the Council or private enterprise should conduct it. In the case of trams a poll held in 1906 was heavily in favour of a private company, to be strictly controlled by the Council. 32 After three years no start had been made. Another poll in July 1909 sanctioned municipal control of the trams. - In August 1911 the trams officially began running and by 1915 nine miles and 21 chains of tram line had been built. Voters were swayed by the failure of private enterprise to raise the capital, by the publicity of the Launceston Tramway League for municipalisation and, above all, by the promise that municipal trams would result in cheaper fares than a private company would charge. 33 In 1906 the electric light scheme had not yet started to show a clear profit and was just covering running costs but by 1909 a six percent return on total capital investment was achieved. 34 This success gave voters the confidence to vote for municipal trams. 35

31. For the lighting scheme see Cyclopedia of Tasmania, op.cit., v.2, p.31-2 and for the trams see Corporation of Launceston, City of Launceston Tasmania 1915, (Launceston, 1915), p.41-6.

32. Ex. 15, 29 September 1906.

33. For a poster published by the Daily Telegraph outlining the League's programme see D.T. 12 July 1909; see also an article by Henry Button relating municipalisation and low costs Ex. 19 May 1909.

34. Ex. 26 September 1906; D.T. 16 June 1909.

35. D.T. 16 July 1909 gave the best account of why the vote was in the affirmative, including "the lucid and convincing statement by Alderman Oldham of the facts and figures which reveal the success of the City Council's large electric light, heat and power enterprise". 
Thus in terms of the range of services provided, it is clear that municipalisation had a strong hold in Launceston. How did contemporaries view the growth of municipal intervention? In December 1895 the Mayor, W.H. Ferral1, a prosperous butcher, brimming with civic pride, claimed in his valedictory address that there was no other city "of the same size and population in the colonies enjoying any greater beneficial results from municipal government, and at such a limited and economical outlay by the citizens" of 3 shillings in the pound. 36 Thus efficient services cheaply supplied was emphasised and this was the dominant view of the advantages of municipal control. A more interesting manifestation of the same view was stated by Mayor J.W. Pepper, a leading businessman, in 1904. Showlng the influence of Joseph Chamberlain, Pepper described the Council as "a large commercial concern": the aldermen were "the directors" and the ratepayers were "shareholders". 37 The aim of the municipal business was to provide services "as cheaply as possible" in the interests of the shareholders.

At times an ideological element surfaced. In 1906 Charles Russen, the new Mayor and "a working Christian", talking at a St. Patrick's Day Anniversary celebration, described the services offered by the Corporation, stressing the low costs, and added: "I was called a socialist the other night .... Well if that is socialism, I am glad to practice it". 38 Linking socialism with municipal intervention was an alarmist cry by opponents of

36. Ex. 3 December 1895.

37. Ibid 1, 2 December 1904.

38. D.T. 16 March 1906; Ex. 14 December 1914 for Russen's obituary. 


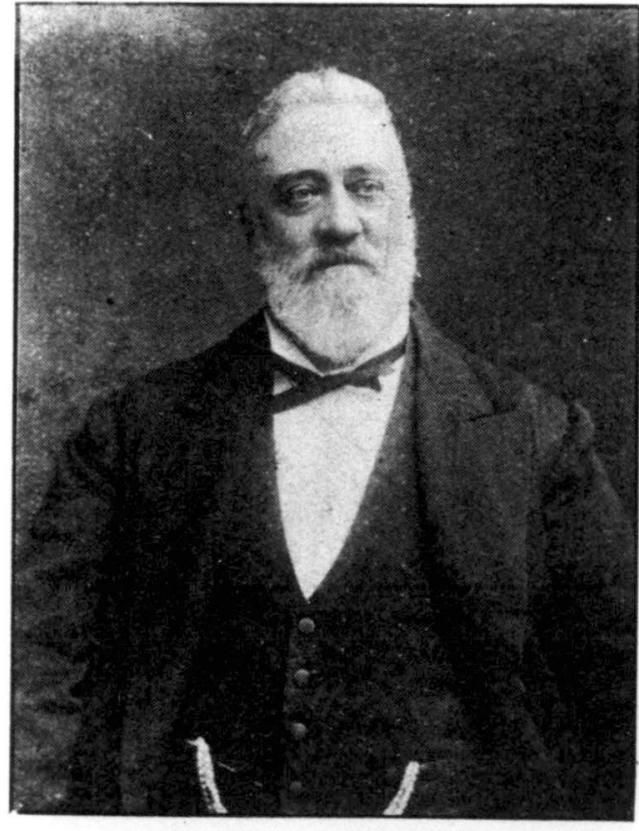

R. MCGUfFIE $C O$.

Mr. S. J. Suttox.

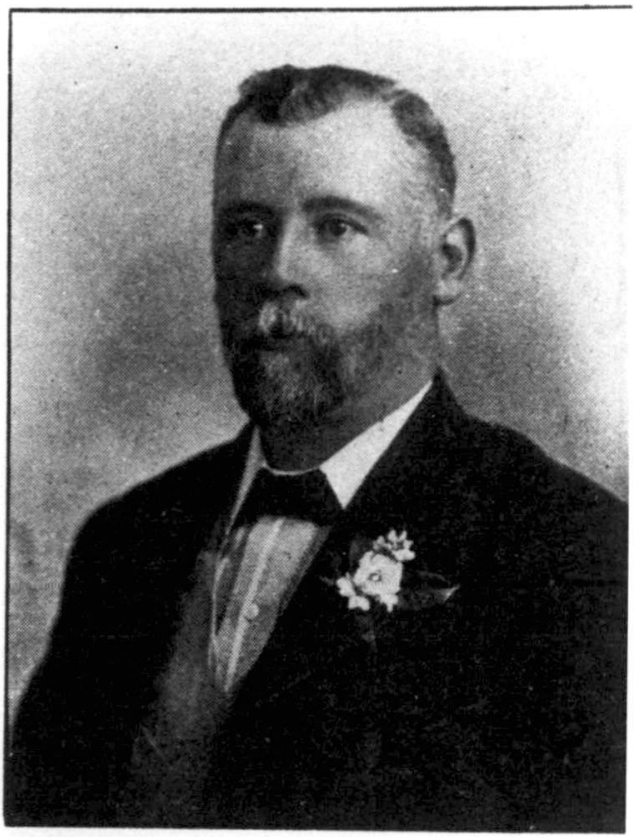

WHITELAW

Mr. C. Ricasen.

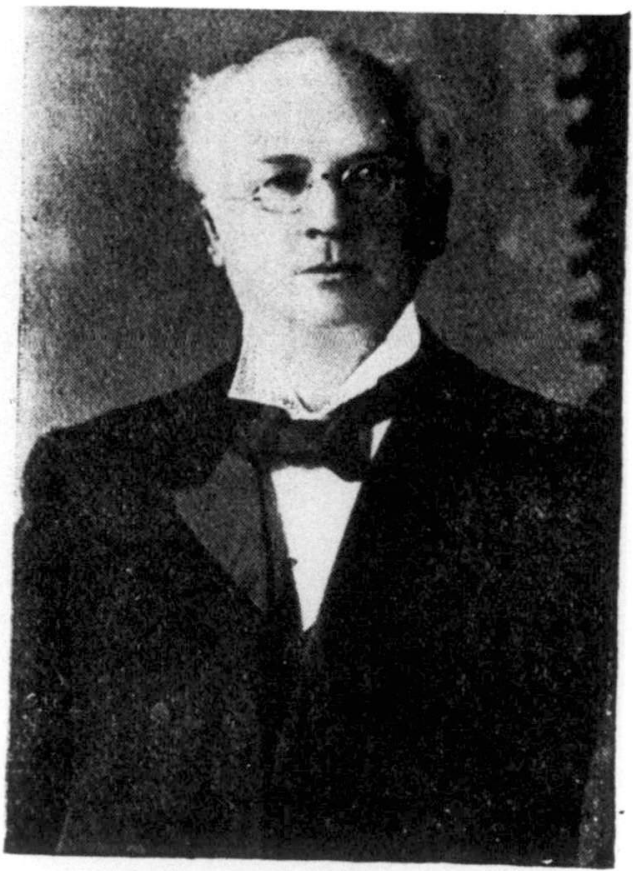

ALDERMAN PEPPER,

Re-elected Mayor of Launceston. 
municipalisation but, as Kellett argued, and as the Launceston experience showed, there was little that was doctrinaire about municipal intervention. The Examiner, for example, while enthusiastically in favour of municipal government, but of politically conservative tendencies, could write in March 1906 that

we see Launceston as a model municipality and recognised as such throughout Australia. Water, light, power and sewerage are all provided by the municipality. Soon, probably, will be addied trams. What next? What in the direction of municipal socialism will follow that? Housing, possibly, for the poor? ${ }^{39}$

Civic pride could be as potent a motive to municipalisation as ideological conviction. The Examiner's view of municipal government was similar to that of Pepper in regarding it as "nothing more or less than a huge co-operative business concern, in which the citizens are the shareholders!" ${ }^{40}$ By 1913 its view of municipalisation had slightly changed. There was "ample . illustration" in Launceston, wrote the Examiner, "of profitable municipalisation of enterprise, but we are not prepared to say that the results are better than could have been achieved by private action under proper control, in which the balance was fairly held between the public and the individual or company". 41 The role of the Corporation should thus be one of regulation but the Examiner saw no argument against the expansion of municipal enterprise "in those matters which constitute natural monopolies, and where ordinary competition does not enter".

39. Ex. 21 March 1906.

40. Ibid 6 December 1905.

41. Ibid 28 July 1913. 
The Daily Telegraph, which espoused liberal views, was a more explicitly consistent exponent of municipal intervention than the Examiner and was aware of the work of British Corporations. In November 1899 the Daily Telegraph believed that Launceston "ranks in municipal affairs in Australia much as the cities of Birmingham and Glasgow do in those of Great Britain". 42 The Launceston Corporation pursued the policy of "the most successfully organized and managed cities in the world" by providing services so that "those who make use of it pay for it but they are served at the lowest possible charges, are not called upon to provide dividends for capitalists, and the municipal rates are not permanently increased; on the contrary, the profits are available for effecting reductions in rates or charges, or for use in other ways for the benefit of the citizens". 43 The Corporation afforded "a luminous example of sound municipal enterprise and management" and its achievements were "the outcome of municipal socialism applied in the rendering of common and necessary public services". 44 The Daily Telegraph used terms like municipal enterprise and municipal socialism interchangeably but always stressed the economic benefits of municipalisation. It also thought that the Corporation was a business, providing services that were "cheaper and more efficient than those obtainable in any other way". 45

The Tasmanian Democrat, Tasmania's first avowedly labour weekly, also closely followed British developments in municipalisation and placed great faith in the power for good of local

\footnotetext{
42. D.T. 28 November 1899

43. Ibid 10 December 1901.

44. Ibid 12 December 1900, 4 December 1906.

45. Ibid 5 December 1905.
} 
bodies. In 1895 the paper quoted Joseph Chamberlain that "Municipal government is the most potent agent of social reform". 46 The Tasmanian Democrat's successor, the Federalist expressed similar sentiments, enthusing, in 1898, that

Great Britain, with her County Councils, has set a lesson to the world by giving free scope for the exercise of that municipal socialism which has effected such marvellous reforms in Glasgow, Manchester, Birmingham and other great cities of the motherland. 47

The Federalist thought that "of all Australian centres, Launceston has attested the most earnest desire for progressive Municipal government". The only obstacle to "civic fraternity" was plural voting at elections.

The Launceston Corporation's management of the city also impressed those not resident in Launceston. In Hobart the Clipper and the Tasmanian News often wrote rapturously of the Launceston Corporation, which also inspired the municipal reform movement there. 48 In 1898 Ben Tillett, the English trade unionist and a Fabian Socialist alderman on the London County Council, visited Launceston as part of an Australian lecture tour. ${ }^{49}$ At a Mayoral reception Tillett said that in Launceston there was "very little for a municipal reformer to suggest - it was a veritable heaven to him - and he was only sorry that other colonial cities

46. T.D. 1 November 1895.

47. Federalist 12 November 1898.

48. see Cl. 13 February 1897; T.N. 8, 11, 17 December 1902; also a speech by the Minister of Lands Edward Mulcahy M. 16 July 1902 .

49. J. Schneer, Ben Tillett: Portrait of a Labour Leader, (London, 1982). This biography perhaps understates Tillett's view of the importance of municipal government. 
were not so advanced". 50 Compared with Hobart Launceston was "a fairy-tale" and he praised its "excellent municipal spirit". In 1901 Senator George Pearce, founder of the Labor Party in Western Australia, came to Launceston as a member of the Select Committee on steamship services between Tasmania and the mainland. 51 Pearce believed that "those engaged in municipal work on the mainland .... [should] 1 look at this city and learn what the Corporation here is doing. I never saw a better managed city". 52 In 1902 George Ellery, Town Clerk of Adelaide, writing of municipal government in Australia for the New York journal Municipal Affairs, described Launceston as "far in advance of most Australian cities in the development of municipal functions". 53 Finally in 1909 W.G. Spence, a pioneer of the Australian labour movement, immortalised Launceston's achievements in a chapter on "Socialistic Enterprises" in his book Australia's Awakening. 54

These impressions of the Launceston Corporation stand in sharp contrast to the opinions held of the Hobart Corporation, as we will see in Part Three. On first appearances both Corporations operated under similar conditions. As we know they were incorporated at the same time and under the same legislation. Each city was a seaport and were "commercial centres for considerable areas of territory". 55 Yet in Launceston civic services

50. Ex. 5 March 1898.

51. P. Heydon, Quiet Decision: A Study of George Foster Pearce, (Melbourne, 1965).

52. D.T. 22 October 1901.

53. Ellery, op.cit., p.46; For Ellery see F. Johns, Johns' Notable Australians, (Melbourne, 1906), p.65.

54. W.G. Spence, Australia's Awakening: Thirty Years In the Life of an Australian Agitator, (Brisbane, 1942), p.388.

55. D.T. 15 August 1901. 
were manifold and praised for efficiency, while in Hobart civic services were criticised for being inefficient or non-existent, being run by private companies. A basic "difference of standpoint", wrote a special correspondent of the Tasmanian News, who visited Launceston in 1902, was:

Suggest 'a rational improvement to any average body of Launceston citizens, and, if it is reasonably within their means they'll clamour for it with enthusiasm: suggest a rational improvement to an average body of Hobart ratepayers and they' 11 decide that this means a penny rate and is Anathema, or at best is something to be longed for as a remote and abstract good. 56

The special correspondent interviewed an unmạed "Launceston citizen of repute" who stressed that the reason for Launceston's "progressiveness" was "that we take, in due proportion, as active an interest in our civic as in our private concerns". He added "that almost every reputable citizen is absolute and sincere in his desire to push the city to the front, or, at any rate, to keep it abreast of the times". The Hobart aldermen, according to another "prominent" Launcestonian, "don't say so, but they have an ineradicable idea that any notable extension of municipal enterprise is a reckless perversion of the ancient order, and as such ungodly in essence. They have made Monopoly, marked as Private Enterprise, their fetish". Hence the Tramway Company could use the streets of Hobart in any way it liked and a private company was likely to introduce electric lighting to the city.

56. T.N. 8, 17 December 1902 . 
In Launceston, believed G.T. Collins, an influential politician, there was "a bond of union between the people and .... they were proud to have the city to live in". 57 The Hobart Mercury also noted in 1906, Launceston's centenary year, "the public spirit and pride in their city which is a characteristic of so many of its citizens" and which was lacking so obviously in the citizens of Hobart. 58 The Mercury confidently asserted that it was this spirit which has made Launceston what it is and has resulted in the building up of a city of which its inhabitants can be proud. Its municipal government is notably good, and the strong civic patriotism for which the citizens are known has helped the Corporation to make it, in some respects, a model city.

In England municipalisation was stronger in the North than the South, where private interests were more "entrenched": also urban growth was more rapid in the North and put greater pressure on existing services. 59 It is doubtful that the difference between Hobart and Launceston can be explained in this way. Both cities were settled at about the same time, although Launceston did not become the major town of northern Tasmania until $1824 .^{60}$ Capitalism was as equally "entrenched" in Launceston as in Hobart. 61 The relationship of the two cities to the central Government had a greater bearing on the development of municipalisation than any

57. D.T. 20 February 1906.

58. M. 21 March 1906.

59. Falkus, op.cit., p.138.

60. Beever, op.cit., p.3.

61. "New Chum" in A Ramble in Launceston, (Launcestion, 1879), p.26 described Launceston as "essentially a tradıng community" with "a trading aristocracy" and "Most of the Launcestonians buy shares". 
other factor. Launceston had always felt a sense of isolation and neglect by the Government, centred at Hobart, and this fostered community consciousness. Launceston also lacked the natural advantages of site that Hobart enjoyed and municipalisation was partly a pragmatic response engendered by a difficult environment. 62 Incorporation was seen by citizens as a way of mastering their own destiny in the face of an uncaring Government. As the capital of the colony, the Government, claimed the Examiner, had always bestowed much attention and money on Hobart. ${ }^{63}$ After incorporation, the Hobart Corporation taxed ratepayers "lightly and looked to the Government to assist them out of all difficulties into which their own extravagance or negligence led them". Governments were predisposed to subsidise those who made "the most clamour, or could bring most political influence to bear", which the Hobart Corporation, because of its proximity to Parliament, could do. According to the Daily Telegraph the expenditure of "so much State money .... had the effect of drugging munıcipal enterprise and resource" in Hobart while "the lack of that advantage has been the means of developing a spirıt of progress and selfreliance" in Launceston. 64

This picture of progress and general satisfaction with the work of the Launceston Corporation predominated for most of the period 1885 to 1914 but there were issues that caused public discontent with the Corporation. In particular the period 1890 to 1897 saw an attempt to introduce reform, when some of the angels

62. See the comments on Launceston's site by Governor Macquarie, quoted in Button, op.cit., p.401-2.

63. Ex. 25 January 1884.

64. D.T. 15 August 1901. 
in Tillett's municipal "heaven" expressed dissent. In England public health became the focus of municipal reform. 65 This was also true of Hobart, as we will see, but less true of Launceston, where the Corporation reacted quickly to overcome the causes of typhoid epidemics that occurred from 1887. However in Launceston it was the case that the unanimity and decorum that generally characterised municipal life was undermined by public debate over the administration of the Sanitary department by the Sanitary Officer John Bushman. At first opposition was aroused by the Corporation's increasing intervention in public health but this was short-lived and was confined to a small group of ratepayers. Most Launcestonians did not deny the Corporation this right but many were critical of Bushman's manner and methods. As we have seen Bushman provoked opposition soon after his appointment in 1883 and this was intensified in the period 1887 to 1896 , when he was replaced by $\mathrm{Dr}$. John Wilson. Aldermen were elected with the specific aim of achieving Bushman's dismissal and these same aldermen often advocated municipal reform. The administratıon of the Sanitary department by Bushman and his successors and Launceston's sanitary problems form the subjects of the next three chapters. The rest of this chapter will consider aspects of municipal reform in Launceston.

In England for much of the nineteenth century the overriding function of municipal governments was to act "as trustees of public funds". 66 Councils were judged by how well they ad-

65. Fraser, op.cit., p.167.

66. B. Keith-Lucas, The English Local Government Franchise: A Short History, (Oxford, 1952), p.9-10; see also D.E. Ashford, "A Victorian Drama: The Fiscal Subordination of British Local Government" in D.E. Ashford (ed.), Financing Urban Government In the Welfare State, (London, 1980), p.71-96. 
ministered the rates. As the Examiner wrote: "Municipal, even more than State, government is principally a question of pounds, shillings and pence. The citizens are .... directly interested in the careful and economical administration of money". 67 In genera1, at least until 1893, the management of the Launceston Corporation's finances received little criticism as no Australian Corporation had "a better record .... of careful management and consistent economy". 68 By 1893 total rates were 3s. 5d. in the pound and the general rate was $1 \mathrm{~s}$. $3 \mathrm{~d}$. (Table 2) The stability of the Launceston Corporation's finances was disrupted by the depression of the early 1890s. In 1893-4 the Government stopped grants-in-aid for streets. 69 To save money minor amalgamation of positions were made but reductions in salaries did not receive much public or aldermanic support. ${ }^{70}$ The work of city officials was widely appreciated and, as workloads were likely to increase, salary cuts were considered not to be justified.

Attempts by the Corporation to save money failed to satisfy a section of ratepayers. Demands for more savings and lower rates were made at municipal' elections. In December 1893 Abraham Barrett announced his candidature in an advertisement, promising that if elected he would "endeavour to work for the advancement and welfare" of the city "with a11 due regard to efficiency and a just economy". 71 Barrett was the first of a number of aldermen who undertook to replace "the reign of expenditure" with "a reign of economy". 72 Apart from the depression, public controversy over

67. Ex. 3 December 1895.

68. Ibid 29 October 1892.

69. Ibid 16 October 1894.

70. Ibid 28 November 1893; D.T. 29 November 1893.

71. D.T. 5 December 1893.

72. Ex. $10 \mathrm{July,} 4$ September 1894. 
TABLE 2 : LAUNCESTON CORPORATION RATES LEVIED IN THE POUND

\begin{tabular}{|c|c|c|c|c|c|c|c|}
\hline Year & Genera1 & Police & Water & Sanitary & Lighting & Special Sinking Fund & Total \\
\hline 1885 & 1s. $5 d$. & $9 \mathrm{~d}$. & 1s. $2 \mathrm{~d}$. & - & - & - & 3s. $4 d$. \\
\hline $1886-7$ & 1s. $5 \mathrm{~d}$ & 9d. & ls. $3 d$. & - & - & - & $3 s .5 d$. \\
\hline $1888-93$ & 1s. $3 \mathrm{~d}$. & $9 \mathrm{~d}$. & 1s. 3d. & $2 d$. & - & - & 3s. $5 d$. \\
\hline 1894 & 1s. $3 \mathrm{~d}$ & $9 \mathrm{~d}$. & $1 \mathrm{~s}$. & $2 d$. & - & - & 3s. $2 \mathrm{~d}$. \\
\hline 1895 & $8 \mathrm{~d}$ & $9 \mathrm{~d}$. & $9 \mathrm{~d}$. & $2 \mathrm{~d}$. & - & $2 \mathrm{~d}$. & $2 s .6 \mathrm{~d}$ \\
\hline 1896 & JOd. & $8 \mathrm{~d}$. & $8 \mathrm{~d}$. & $2 \mathrm{~d}$. & - & $8 \mathrm{~d}$. & $3 s$. \\
\hline $1897-8$ & $10 \mathrm{~d}$ & $8 d$. & $7 \mathrm{~d}$. & $2 \mathrm{~d}$. & $4 d$. & $8 \mathrm{~d}$. & 3s. $3 d$. \\
\hline 1899-1901 & 1s. & - & $7 \mathrm{~d}$. & $2 \mathrm{~d}$. & $4 d$. & $8 \mathrm{~d}$. & $2 \mathrm{~s} .9 \mathrm{~d}$ \\
\hline 1902-1905 & ls. & - & $8 d$. & $2 \mathrm{~d}$. & $4 d$. & $8 \mathrm{~d}$. & $2 \mathrm{s.10d}$ \\
\hline $1906-14$ & 1s. $2 \mathrm{~d}$ & - & $8 \mathrm{~d}$. & $2 \mathrm{~d}$. & $4 d$. & $8 d$. & $3 s$. \\
\hline
\end{tabular}

Source: Hobart Gazette, Tasmanian Government Gazette. 
the electric light scheme led to the rise of the economy aldermen. In June 1892 a pol1 taken on the electric light scheme resulted in a vote of 2173 votes for and 690 against the scheme. ${ }^{73}$ The large affirmative vote was based on an estimate of a rate of $6 \mathrm{~d}$. in the pound but in September 1893 the Launceston Water and Light Bill, drafted by the Corporation, increased the rate to $2 \mathrm{~s}$. in the pound. ${ }^{74}$ Ratepayers were outraged and 1400 signed a petition against the Bill: the Gas Company, from self-interest, also protested. $^{75}$ Alan McDonald, soon to be elected to the House of Assembly and regarded by some as Tasmania's first Labor member, claimed that if ratepayers had known that electric light would cost more than gas the result of the poll would have been reversed. 76 The Bill was withdrawn. The electric light controversy undermined the "respect and confidence" of the citizens in the Corporation and exposed aldermen and their management of finances to penetrating examination. 77 The rate eventually paid for electric lighting was $4 \mathrm{~d}$. in the pound.

A pre-occupation of the economy aldermen was to force adherence to strict accounting procedures, especially to ensure that money raised and spent by a particular municipal department was plainly set out. This was illustrated by the arguments used in the reduction of the water rate. The water rate, claimed the Examiner,

73. Ibid 1 July 1892 .

74. Ibid 16 September 1893.

75. Ibid 28 September, 17 October 1893.

76. for McDonald see R.P. Davis, "Tasmania" in D.J. Murphy (ed.), Labor in Politics: The State Labor Parties in Australia 1880-1920, (St. Lucia, 1975), p.394.

77. Ex. 21 September 1894; T.D. 5 July 1895. 
was much higher than necessary because there was "less hostility" to paying a high rate for water than other services and the extra money raised was used to pay for work "that should be borne by other branches of the municipal service". 78 It believed that "whatever is essential to the life and health of every individual, if it is a monopoly held by the Corporation, should be supplied at cost price". 79 The Examiner criticised the use of money raised from the excessive water rate to build the Albert Hall at a cost of $£ 12,000 .^{80}$ Barrett regarded using money from the water account for other purposes as "very like obtaining money under false pretences". 81 The Daily Telegraph agreed that water used for domestic purposes should be rated as low as possible but the Corporation could make "a fair profit" from water used for "commercial purposes or luxuries". 82 Aldermen could justify their actions by referring to the practice of British Corporations. Alderman G. Croșby Gilmore, for instance, quoted from Frederick Dolman's book Municipalities at Work, to show how the Corporations of Birmingham, Glasgow and Manchester used profits from water and gas rates to subsidise other works. 83 The economy aldermen succeeded in re-organising accounting procedures. Apart from lowering the general and water rates, a special sinking fund rate of $8 \mathrm{~d}$. in the pound was charged to pay off loans. The Launceston

78. Ex. 19 February 1895.

79. Ibid 6 May 1895.

80. Ibid 12 December 1894.

81. Ibid 8 April 1895.

82. D.T. 25 April 1895.

83. Ex. 30 April 1895; see also Ashford, op.cit. and E.P. Hennock, Fit and Proper Persons: Ideal and Reality In Nineteenth-Century Urban Government, (London, 1973), p.276-7. 
Corporation Act 1895 provided for the Auditor-General to audit municipal accounts. By 1897 the upshot was that, including the new rate charged for lighting, total rates levied amounted to 3s. 3d., just 2d. less than in 1893. While some economy was thus achieved the emphasis was also on tightening accounting methods. 84 In 1899, after centralisation of the police removed the necessity to charge a police rate, total rates amounted to $2 \mathrm{~s}$. $9 \mathrm{~d}$.

By 1900 demands for economy had subsided. Mayor Panton criticised the economy aldermen for their "policy of freely carrying out public works, using the reserve funds, lowering the assessments and reducing the rates", which forced the Corporation to seek "Parliamentary sanction .... to wipe off its debit balances and start with a fresh sheet". 85 Panton called for a return to the policy initiated when municipal government was established: "to keep up the assessment and the rates, especially the water, and provide good reserve funds for emergencies and to execute such public works as were very necessary". Rates were increased by 1d. in 1902 and by 2d. in 1906. The press supported these increases and even justified further increases. 86 Natural increases in the rateable value of property, and later profits derived from lighting and tram utilities, helped aldermen avoid adding to the rates. 87 However money for street building and repair was required and the City Engineer never ceased pointing this out to aldermen. 88

84. The economy aldermen were criticised for not going far enough see for example let $t \in \mathbf{r}$ by "Disgusted One" Ex. 10 February 1896.

85. Ex. 11 December 1900.

86. D.T. 2 February 1904, 19 February 1913; Ex. 6 December $1905,6,7$ February 1906, 10 December 1912 .

87. see the report of the Finance committee Ex. 20 February 1912.

88. The City Engineer noted in his 1911 annual report that he had asked for increased allocations for streets since 1892. Ex. 23 January 1912. 
In England the dependence on rates from real property, according to Hennock, limited the activities of municipal councils because "it did not adequately reflect the enormous growth of wealth due to commercial and industrial activities". 89 Notwithstanding the revenue gained from the electric light and tram services, the Launceston Corporation was also dependent on rates from real property and this meant that finance would always arouse passionate debate. Only major increases in rateable value would make possible significant advances in "social conditions".90 As we have seen during the boom period of the Tasmanian economy, from 1870 to 1891 , annual rateable value more than doubled, reaching $£ 135,168$; by 1901 it had dropped to $\$ 128,434$; and due to the return to prosperity in the years to 1914 annual rateable value in Launceston had reached $£ 182,148$. $^{91}$ This steady increase provided the Corporation with adequate funds but did not reflect the profits accumulated by mining or manufacturing interests. The need for alternative sources of revenue was discussed at annual conferences of the Launceston and Hobart Corporations in the 1890s. Alternative sources included the payment of all licence fees collected in a municipality to the local authority, the assessment of Government buildings on the same basis as private lands and houses and assessing the capital value on unimproved property but apparently the two Corporations failed to secure Government support. ${ }^{92}$ To sub-

89. E.P. Hennock, "Finance and Politics in Urban Local Government in England 1835-1900", Historical Journal, v.6, 1963, p.215.

90. N. McCord, "Ratepayers and Social Policy" in P. Thane (ed.), The Origins of Britush Social Policy, (London, 1978), p.33.

91. Knibbs, op.cit., p.144-5. The drop was part1y due to the new methods of assessment introduced by the economy aldermen.

92. Ex. 13 March 1893, 23 January 1894. 
sidise essential large public works, such as drainage, water supply and the electric light scheme, the Launceston and Hobart Corporations had no choice but to borrow money, mainly from the London money market. In 1875 the Launceston Corporation's outstanding loans stood at $£ 51,796$; in $1901 £ 283,936$; and in $1914 £ 453,758.93$ Parliament offered little opposition when power to borrow this money was sought. These loans, said Samuel Sutton in 1905, were "expended in securing reproductive advantages. Therein was the whole genius of municipal borrowing". 94

While the citizens of Launceston might have been grateful to aldermen for their sound management, the press often claimed that even greater progress would be achieved if other men became aldermen. In November 1889 the Examiner, acknowledging that since the first elections "every alderman has worked honestly and conscientiously, so far as his abilities would permit, for the benefit of the town", perceived "a marked reluctance on the part of leading representative citizens to come forward for a seat in the Council Chamber". 95 Men who possessed "clear business abilities" were wanted as aldermen because it was "the businessmen generally who have the largest stake in the community". 96 Such men were approached at every election but refused to stand and gave priority to their business interests. The Daily Telegraph also noted that "Instead of the most respected and successful businessmen of the community striving with earnest emulation to enter the aldermanic ranks, the best men generally stand aloof". 97

93. Knibbs, op.cit., p.144-5.

94. Ex. 23 December 1905.

95. Ibid 28 November 1889.

96. Ibid 5 December 1893, 22 January 1901.

97. D.T. 24 November 1894. 
One theory why the best businessmen did not contest municipal elections was that they would only stand if victory was highly likely. In November 1905 the Examiner held its own poll and asked ratepayers to nominate six men who they considered to be suitable aldermanic candidates. 98 This show of public support might give the men chosen confidence to stand at the approaching elections. As an incentive to ratepayers, the person who picked the first six men would win two guineas. The result of the poll indicated that there was a wide range of opinion as to who were regarded as the most suitable candidates. Votes were received for 120 names. 99 The first eight were "well known in business circles": Charles Russen, E.M. Law, Jas. Barclay, Tas Shields, C. Dempster, A. Munnew, George Harrap and Thomas Bourke. Russen was already an alderman and of the others only Munnew successfully contested the municipal elections before 1914. 100

This emphasis on the quality of aldermen neglects the important role of the civic bureaucracy, which, with various reports, would shape the views of aldermen and would administer the money borrowed or raised once aldermen had decided to embark on a particular scheme. ${ }^{101}$ More pertinent is to consider whether the best

98. Ex. 7 November 1905.

99. Ibid 20 November 1905.

100. Ibid 8 December 1905.

101. D. Fraser, "Introduction: Municipal Reform in Historical Perspective" in D. Fraser (ed.), Municipal Reform and the Industrial City, (Leicester, 1982), p.11 regards "the growth of the English municipal bureaucracy" as "a much neglected topic of study" and this is true also of Australia. An impression of the crucial role of the heads of the Launceston Corporation departments can be gained from reading the evidence they gave to the Royal Commission on the Municipal Government of Hobart and Suburbs T.P.P. 1901/5, p.151-69. 
businessmen would view election to the Corporation as relevant to their interests. ${ }^{102}$ That municipal revenue was derived from rates levied on real property made it more likely that men with property interests, especially those deriving most of their income from rent, wanting to keep rates low, would see election to the Corporation of more direct interest than large merchants, manufacturers or mining investors, who would constitute Launceston's economic elite. This elite would be more likely to become involved with the Marine Board, Chamber of Commerce or Stock Exchange than the Corporation. Although it is hard to determine whether aldermen were the best businessmen, a significant number were active members of these bodies. Most aldermen owned or were partners in a business and most had diverse economic interests, being directors of banks or building societies. (Table 3 ) A number of aldermen appear to have gained in wealth by investing in the mining boom. Some aldermen were very prominent in the business 1ife of Launceston. Samuel Sutton, for example, who was responsible for Tasmania's first International Exhibition in 1891, was an alderman from 1885 to 1905 and Mayor four times. 103 He was largely responsible for the Albert Hall and the electric lighting scheme and was President of the Chamber of Commerce. By occupation Sutton was in turn a baker, confectioner and proprietor of the Metropole Coffee Palace, "the largest house of its kind in Tasmania". ${ }^{104}$ Also active in the Benevolent Society,

102. For an instructive analysis of why particular kinds of men would want to become aldermen see M.J. Daunton, Coal Metropolis: Cardiff 1870-1914, (Leicester, 1977), Chapter 9.

103. S. and B. Bennett, Biographical Register of the Tasmanian Parliament 1851-1960, (Canberra, 1980), p. 157; Button, op. cit., p.342, 355.

104. Cyclopedia of Tasmania, op.cit., v.2, p.86. 
table 3 : occupations of Launceston aldermen

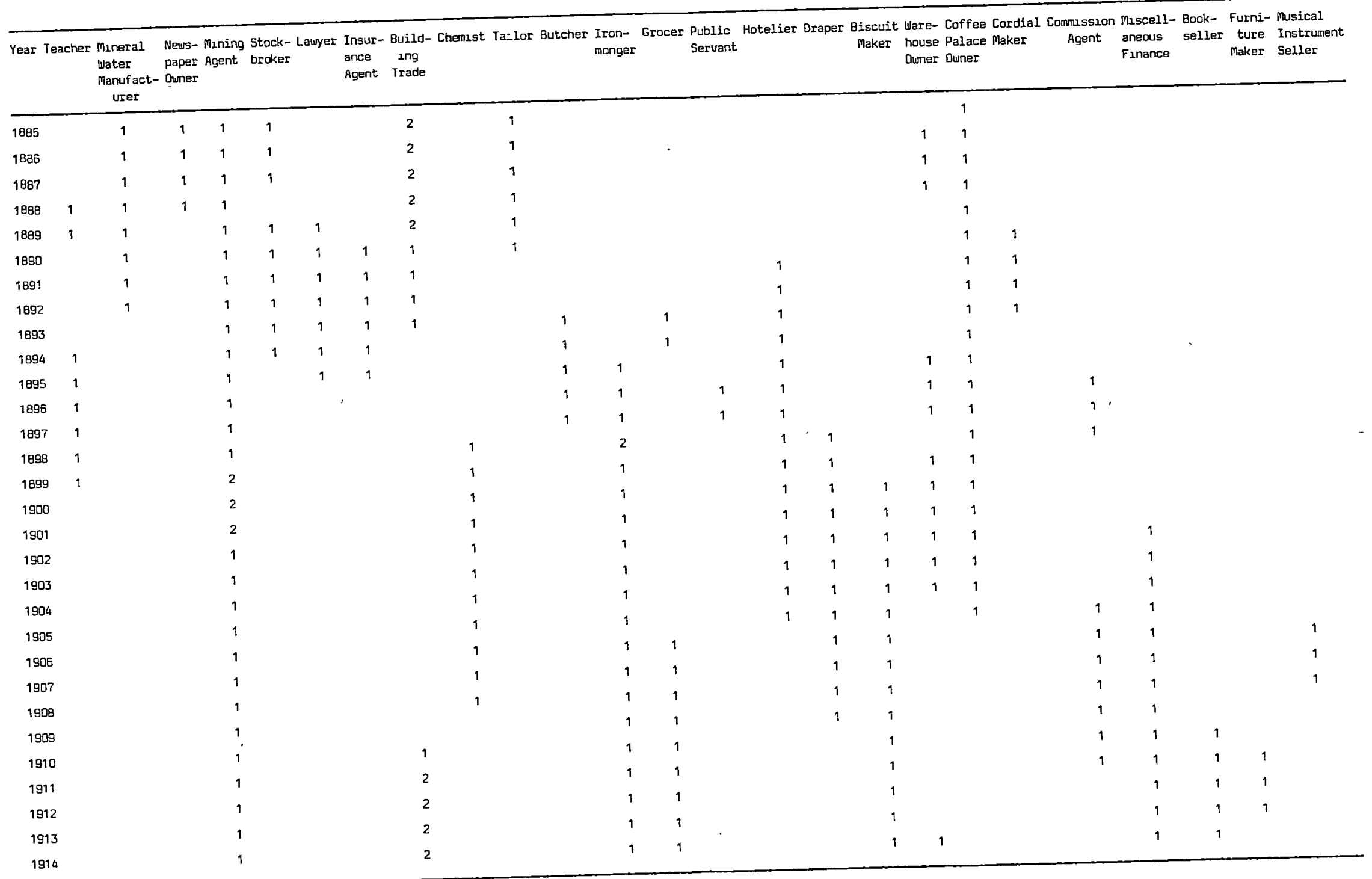

Source: Dbituaries

Directories
Cyclogedia of Tasmania. v.2 
Sutton was the epitome of the public spirited businessman and, wrote the Examiner, " a type to whom British local governing institutions owe a large amount of their success". 105 As the commercial capital of Tasmania, Launceston had plenty of successful businessmen like Sutton whose talents could be used and it was the combination of business acumen and social responsibility that was characteristic of most Launceston aldermen from 1885 to 1914.

From about 1890 an important development for municipal reform was the organization of ratepayer bodies as electoral pressure groups. Prior to 1890 , elections were mainly fought on the liquor question. In 1889 the Examiner claimed that "for very many years the Municipal Elections in Launceston have been decided on this question .... The all-important subjects of sanitation, streetmaking, the health and prosperity of the city, have been set aside while the battle raged round the standard of the liquor traffic". 106 The Daily Telegraph felt that while "the Mayor and Aldermen have absolute control of the police .... Municipal-elections [will] be fought on the ticket - Temperance versus the liquor traffic interests". 107 Ratepayer organizations changed this orientation to some extent. Residents of particular areas of Launceston alleged that the Corporation had disregarded their interests. The low lying suburb of Inveresk, built on the Launceston Swamp, was the first, to agltate for improvements. The growth of Inveresk as a suburb had occurred, as we know, when the Government alienated land

105. Ex. 24 November 1905.

106. Ibid 30 November 1889.

107. D.T. 18 December 1888. 


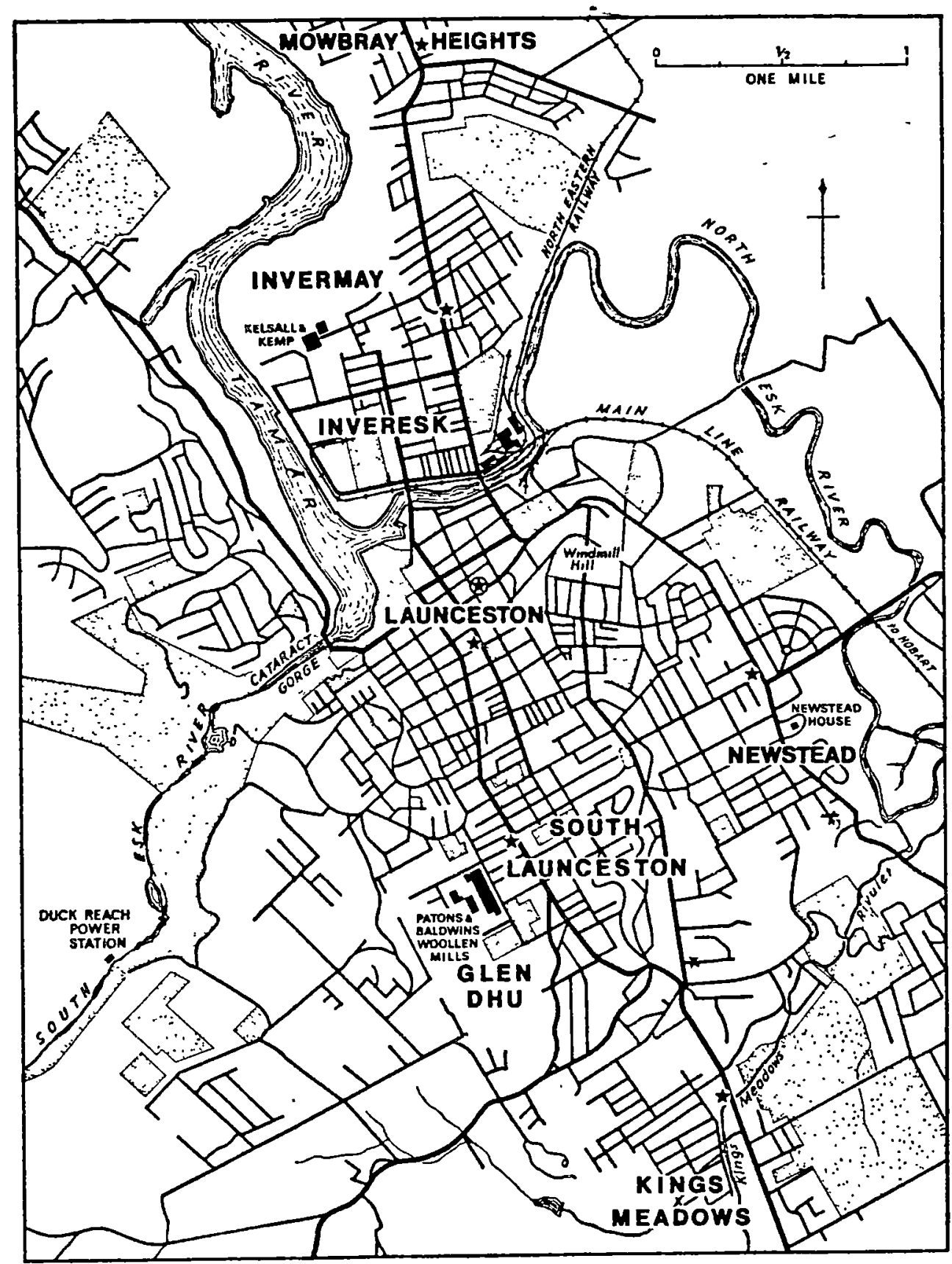

Launceston and suburbs 
there. 108 Only a few houses were included in the Launceston drainage scheme and the Corporation was reluctant to drain the area because it required a large investment of money, which could not be justified by the rates raised from the population of $1150 .{ }^{109}$ Typhoid fever tormented residents of Inveresk and the Gleadow Street ditch running nearby was described as "the birth-place of typhoid" in Launceston but it was a popular suburb for workers because it was close to the city, their place of work and land was cheap. 110 In November 1890 the residents of Inveresk translated their simmering grievances into political action by forming the Inveresk Improvement Association. 111 It demanded that the Corporation drain the suburb and that more money be spent on streets. The Inveresk Improvement Association was an ephemeral organization, achieving little, and the grumbling of residents in Inveresk continued for a long time. ${ }^{112}$ As the suburbs grew other associations were formed. In February 1903 the South Launceston Improvement Association and in August 1914, after a period of rapid growth, the Invermay Improvement Association appeared. 113 Their impact appears not to have been great.

108. H.A.P. $1881 / 40$ from 1866 to 1880 the Crown received $£ 13,778$ 11s. 7 d. from the sale and $£ 4,2219 \mathrm{~s}$. 5d. from the rent of land at Inveresk; J. Reynolds, Launceston: History of an Australian City, (South Melbourne, 1969), p.131-2.

109. Ex. 13 July, 3 August 1886.

110. D.T. 30 April 1889.

111. Ex. 6 June 1891. Ratepayer associations were a common feature of the late nineteenth century but have not received much attention from historians see A. Offer, Property and Politıcs 1870-1914, (Cambridge, 1981), p.297-301.

112. Inveresk was the site of Tasmania's "first formal urban renewal project" in 1975 see R. Giblin, Urban Renewal in Inveresk, (Canberra, 1980), p.7.

113. Ex. 5 February 1903; D.T. 15 August 1914. 
Many disgruntled residents of suburbs were involved in associations that were concerned with the broader sweep of municipal reform. In late 1890 the Launceston Political and Municipal Reform Association emerged. ${ }^{114}$ The major reforms it sought were the ward system and the reduction of plural voting. In part the aim of these changes was to improve the sanitary condition of Launceston in areas like Inveresk but a stronger motive was to make the Corporation more representative. The 1890 s in Launceston, as in Hobart, saw a strengthening of liberal ideas and the democratisation of the Corporation was regarded as desirable in itself rather than for the effect democratisation would have on the policies of the Launceston Corporation. 115 on the other hand in Hobart, as we will see, the reduction of plural voting was seen as the means of making the Corporation more socially responsible.

The ward system was the initial focus of reformers. It had been periodically advocated since incorporation. ${ }^{116}$ By 1890 it had gained currency, wrote the Daily Telegraph, because 'Those living in the suburbs and outer circle of the city proper complain not only that the streets in those portions of the municipality do not receive attention from the Corporation, but that the evil is perpetuated and accentuated by the fact that the totally abnormal representation of property throws the key of the position into the centre of the city. 117

114. D.T. 10 December 1890.

115. Davis, op.cit., p.393 for the strength of liberalism in Launceston.

116. Ex. 25 November 1890.

117. D.T. 13 November 1890. 


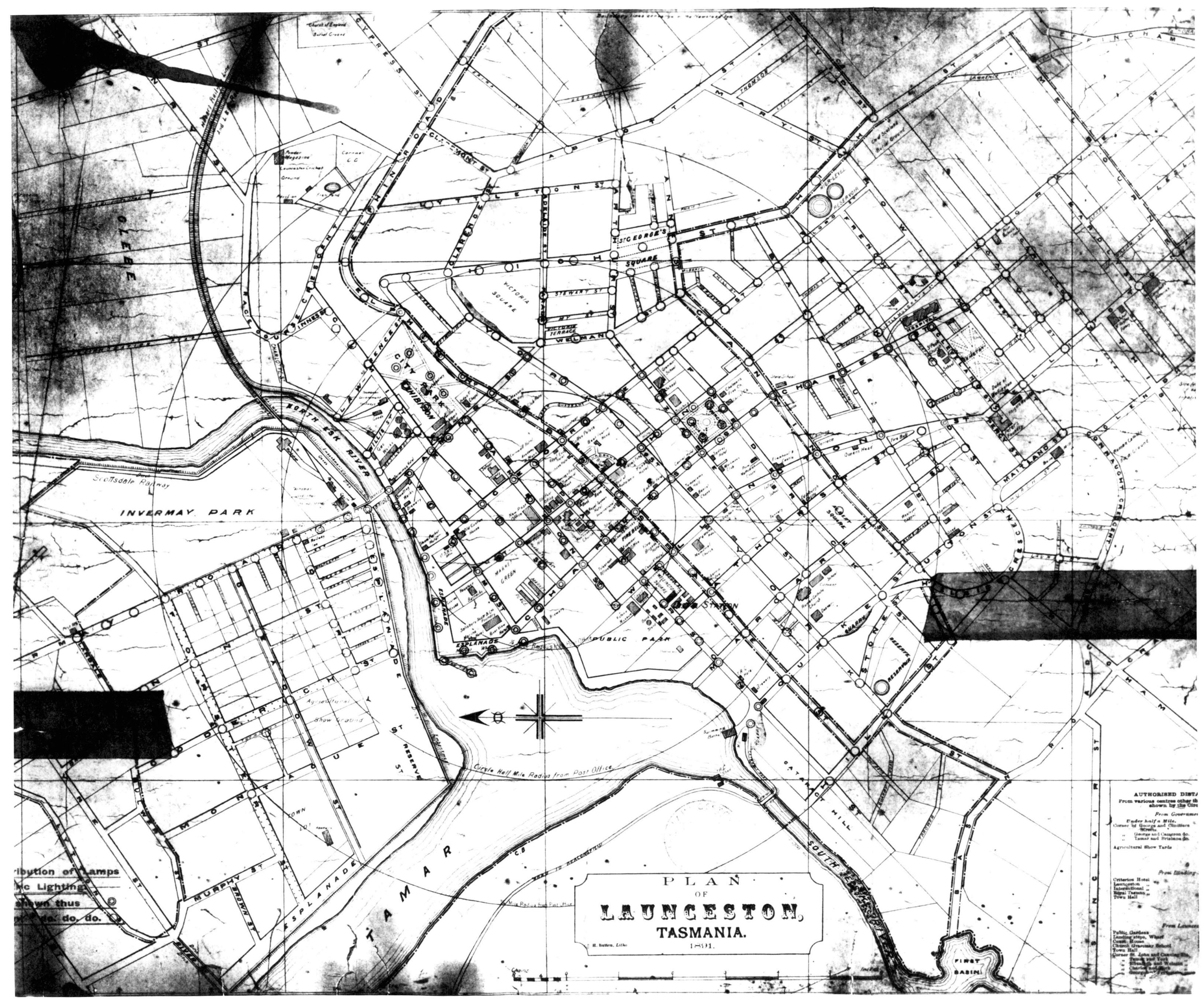


According to one reformer the ward system would "check the influence of plurality of votes, as men could only vote where they paid their rates". 118 The Examiner applauded the appearance of the Launceston Political and Municipal Reform Association because it would bring to prominence important issues at elections instead of the temperance versus liquor question. ${ }^{119}$ It was not enthusiastic, however, about the benefits of the ward system and was not sympathetic towards the claims of the suburbs. The Examiner stressed the large geographical area, three times larger than Hobart, under the control of the Launceston Corporation. Launceston's smaller population was spread all over this large area and "the number of unmade streets is constantly increasing through the cutting up of paddocks into building allotments". The Corporation lacked the money to keep pace with these developments and "only the gradual formation and improvement of outlying streets" was possible. The ward system was suitable for a city with a large population but not for Launceston. The ward system, continued the Examiner, would "parochralise the Council .... secure the return of men fettered by narrow sectional aims, .... whose chief aim is to clutch as much money as possible for their particular district". 120 Aldermen would be forced to place the interests of a section of the city ahead of "the interests of the whole municipality". A seat on the Corporation would thus become even less attractive to "men of a high class either socially or intellectually": the scope of the Council should be broadened and not restricted.

118. Ex. 4 December 1890.

119. Ibid 24 November 1890.

120. Ibid 25 November 1890. These views were similar to those made in America against the ward system see S.P. Hays, "The Changing Political Structure of the City in Industrial America" in A.B. Callow (ed.), American Urban History: An Interpretive Reader with Commentaries, 3rd ed., (New York, 1982), p.241 where he considers urban development in part as "a constant tension between forces making for decentralization and forces making for centralization in human relationships and institutions". 
The Launceston Political and Municipal Reform Association, which appears to have had only a small number of members, held public meetings to popularize the ward system. ${ }^{121}$ On 3 December 1890 a meeting attended by 60 people in the Temperance Hall declared in favour of the ward system. 122 The Association supported two candidates at the municipal election of December 1890: W.I. Thrower, owner of a cordial factory, was returned but David Storrer, owner of a furniture warehouse and undertaking business, was not. ${ }^{123}$ Another candidate E.H. Panton, hotelier and mining agent, who was sympathetic towards the ward system, topped the poll. In January 1891 Thrower moved that the Corporation write to every city in Australia which employed the ward system for details of the way it worked. ${ }^{124}$ The motion was defeated as was a motion by Alderman Price to hold a poll of ratepayers.

In May 1891, after 81 burgesses petitioned the Corporation to consider dividing the city into wards, the Parliamentary committee was ordered to report on the matter. ${ }^{125}$ In August it reported that, under the existing system, "the interests of the whole city are duly conserved, and all expenditure on public works based on a fair and equitable principle". ${ }^{126}$ To test the opinion of ratepayers, the report recommended that a poll be held. The Examiner continued to argue that the ward system lacked general support but the agitation showed "the influence which is sometimes secured for the moment by a small but compact party, assuming the role of reformers,

121. Ex. 2, 3 December 1890.

122. Ibid 4 December 1890.

123. Ibıd 12 December 1890.

124. Ibid 21 January 1891.

125. Ibid 27 May 1891.

126. Ibid 4 August 1891. 
adopting a high sounding and plausible programme, concentrating their efforts on definite objects...."127 Quoting from John Stuart Mill's book Representative Government against the ward system, the Examiner challenged its proponents "to point to any city in the Australian colonies which, in proportion to its size and means, has made greater strides in permanent street improvements, in efficient drainage, abundant and wholesome water supply, ornamentation, and all that contributes to comfort and refinement". 128 In September the report was discussed by aldermen. ${ }^{129}$ Most aldermen agreed with Peter Barrett, an alderman for seventeen years, who denied that favouritism was exercised in the allocation of expenditure and asserted that "strict justice had been done to every part of the city". The report was adopted but it appeared that no poll would be held. This decision failed to stifle further demands for the ward system. In September 1891 the Tasmanian Democrat was published and it soon came out strongly in favour of the ward system. 130 Wards, it wrote, would result in "local representation as opposed to the domination of the city by the centre of the town as at present, so that each ward will be independent of outsiders to decide if that partıcular representative does in reality voice the will of his constituents". ${ }^{131}$ Change was needed because "the central influences have always dominated the Council to the detriment of the City as a whole". ${ }^{132}$ Most aldermen came "from the very small section whose commercial ventures are situated in

127. Ibid 14 August 1891.
128. Ibid 18 August 1891.
129. Ibid 15 September 1891.
130. T.D. 5 December 1891.
131. Ibid 14 January 1893.
132. $\underline{\text { Ibid }} 2 \angle$ April 1893.


the centre of the City" and no alderman was "acquainted with the whole of the names and geographical position of Its streets - the area is altogether too large to expect any ordinary man to look after". The ward system had little to do with the allocation of money, argued the Tasmanian Democrat, because money from rates should be spent "on the most urgent works wherever needed within the bounds of the municipality". Wards were desired "for representative purposes and for representative purposes only".

In August 1892 the newly formed Launceston Municipal Reform League, which also seems to have had a low membership, pressed for the ward system. ${ }^{133}$ Dr. L.S.Holmes was President and the committee included W.F. Wathen, Alex Fowler, G.C. Gilmore and Alan McDonald. When the Launceston Political and Municipal Reform Association disbanded is unclear but the new body probably grew out of it and certainly sought many of the same reforms. Apart from the ward system, the Launcêston Municipal Reform League wanted a reduction in plural voting, the vote for female ratepayers and to ensure that tenants assessed at $₹ 20$ and under, who had paid their rent, should not be disenfranchised by the non-payment of rates, for which the landlord was liable, or if the rates for the previous half-year had been paid. Two of the reforms were acceptable to the Corporation and were adopted, all aldermen voting for the enfranchisement of female ratepayers and only two voting against allowing ratepayers, who had paid rates for the half-year prior to an election, to vote. ${ }^{134}$ Fowler and Gilmore were defeated at the December election but in January 1893, at an extra-ordinary election, Gilmore was successful. 135

133. Ex. 17 August 1892.

134. Ibid 27 September 1892.

135. Ibid 10 January 1893. 
Also in January 1893 aldermen decided to hold a poll on the ward system, to put an end to speculation that it was or was not desired. 136 The Daily Telegraph was relieved because the ward system had been "trotted out at every municipal election for the last five or six years, used for all it was worth to influence votes, and then allowed to slumber peacefully till the next election came round."137 The poll would put the matter to rest. The Tasmanian Democrat was disappointed that the poll was not to be decided by one man one vote. ${ }^{138}$ The poll would be lost unless citizens living in allegedly deprived suburbs like Inveresk, Hampden, Windmill Hill and Cataract Hill voted "solidly in favour of change" as plural voters would vote against the ward system. The Examiner believed wards could only be justified if the Corporation's powers were enlarged to encompass the towns of Invermay, Trevallyn and St. Leonards and if the public works of this larger district were taken over from the Government. 139 Once the Corporation "undertakes the work now done by the Marine Board and becomes the central governing authority for a widely enlarged district the subdivision into wards will follow as a natural sequence".

On 27 April the poll was held. Only a small number of ratepayers voted and a clear majority of 268 votes were cast against wards : popular support was as meagre as the Examiner clalmed. 140 Over the next five years, however, continued agitation by suburban ratepayers succeeded in ensurıng a fair proportion of money was spent on their suburbs. In June 1898, when the suburbs again complained loudly, the City Surveyor Charles St. John David produced an impressive array of statistics to prove that they were

136. Ibid IO January 1893.

137. D.T. 17 April 1893.

138. T.D. 15 April 1893.

139. Ex. 24 April 1893.

140. Ibid 28 April 1893. 
not disadvantaged. ${ }^{141}$ (Table 4) David divided the city into four wards and, for the years 1893 to 1897, showed how much money had been spent in each ward on streets and sewerage, the assessed rateable value of each ward and the proportion of rates raised to money spent. The figures clearly illustrated that the North and South wards, considered by some to be deprived of funds, received "very much more than their due" and East ward, accused of soaking up most of the Corporation's funds, received "but little over one half of its proper share". The inequitable distribution of municipal funds was the main reason cited for the necessity of wards but David's report, wrote the Examiner, "completely cuts the ground from under this contention". 142 Thus the wealthier suburbs subsidised poorer suburbs, as advocated by municipal socialists in England.

In 1906 the Local Government Act created a Boundaries Commission to redraw municipal boundaries with the aim of reducing the excessive number of local authorities in Tasmania. ${ }^{143}$ It was proposed that the Town Boards of Invermay and Trevallyn amalgamate with Launceston. Reservations were expressed that, as the outlying suburbs had been allegedly neglected by the Launceston Corporation, the needs of the residents of Invermay and Trevallyn would also be disregarded. ${ }^{144}$ Amalgamation was further jeopardised by the intention of the Launceston Corporation to charge higher rates than would have been charged by the individual Town Boards. ${ }^{145}$ As the Corporation was

141. Ibid 14 June 1898.

142. Ibid 17 June 1898.

143. see V.G. William "Local Government Reform 1906-07: A Permanent Panacea?" unpublished B.A. Hons. Thesis, University of Tasmania, 1969.

144. Ex. 10 July 1906.

145. Ibid 24, 25, 27 April 1907. 
TABLE 4 : MONEY ALLOCATED TO PARTICULAR SECTIONS OF LAUNCESTON 1893-7.

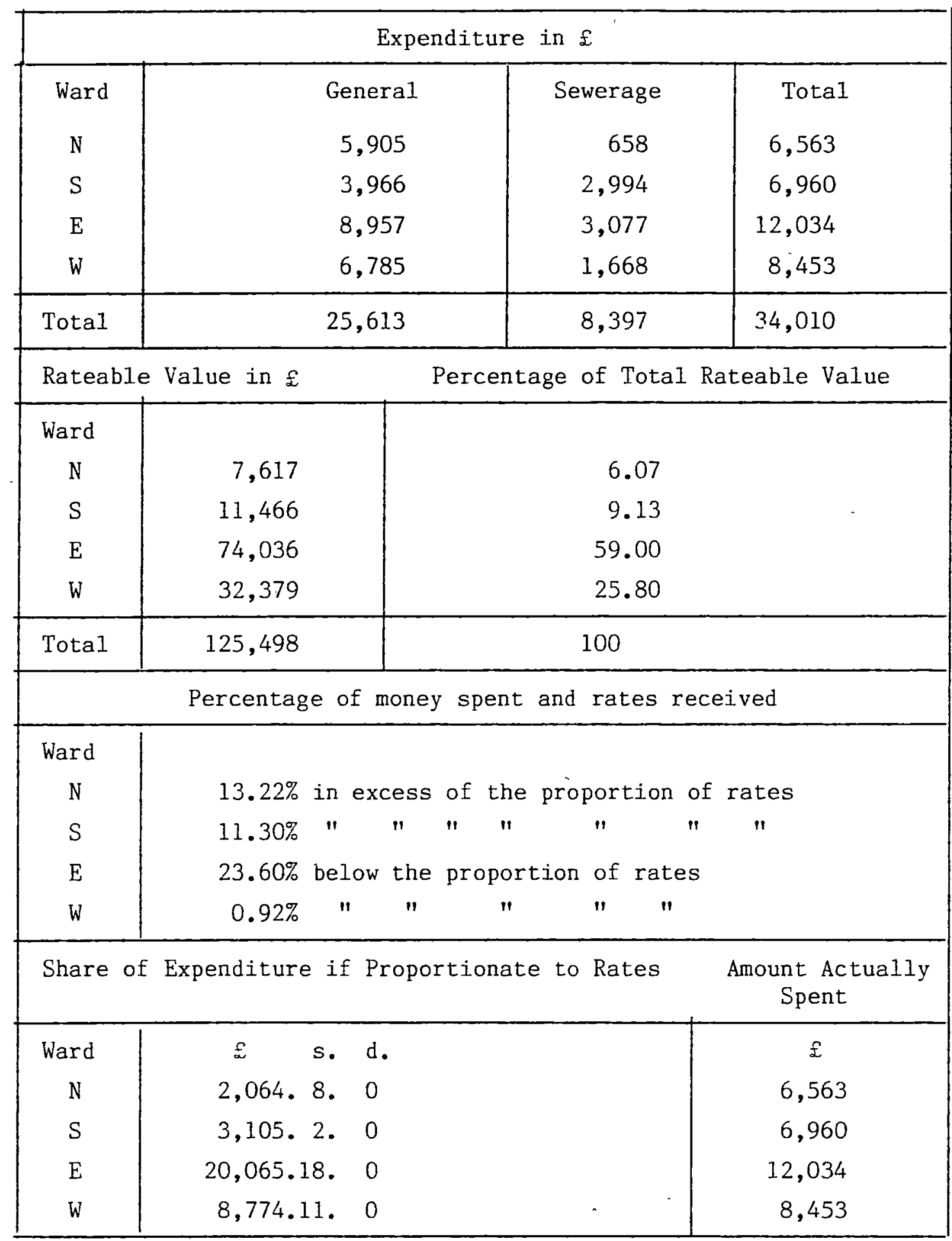

Source: Ex. 14 June 1898. 
in favour of amalgamation, it was forced to reduce the rates and pacified the Town Boards. 146 Supporters of amalgamation, such as the Examiner, stressed the services already provided by the Corporation to residents in Invermay and Trevallyn, such as the water supply, and the services that would be gained, such as the sewerage scheme and the trams, at a lower cost than the Town Boards could provide. 147 Mayor Charles Russen made similar points and thought that the Health Act "could be better complied with by having unanimity of action". 148 To the Daily Telegraph Greater Launceston was justified on grounds of efficiency, economy and physical proximity. 149 Polls held in Invermay and Trevallyn supported amalgamation and it was made formal by the Greater Launceston Act 1907. Strangely the extension of the area under the Launceston Corporation's control from 3343 acres to 5700 acres did not revive demands for the ward system. In 1911 the City Progress Association was set up to oppose the decision of the Corporation to augment electric power by a steam plant and it advocated wards during the municipal elections. 150 The convincing defeat of the City Progress Association candidates David Storrer, T. Searell and W.E. Sadleir ended further agitation for wards. 151

Although municipal reformers had failed to secure the ward system for Launceston, their attack on plural voting brought some success. The municipal franchise and restrictive property

146. Ibid 30 April, 28 May, 5 June 1907.

147. Ibid $10 \mathrm{July} 1906$.

148. Ibid $10 \mathrm{July} 1906$.

149. D.T. 3, 12 July 1906.

150. Ex. 21 November 1911; D.T. 6 December 1911.

151. Ex. 8 December 1911. The three retiring aldermen polled 5793 votes to the three challengers 2279 votes. 
qualifications for aldermen were, as was the case in Hobart, the chief targets of municipal reformers. In Launceston persons owning property rated at $£ 240$ and over were eligible for seven votes at municipal elections. (Table 5) To become an alderman a male ratepayer had to possess real estate valued at not less than $£ 500$ or be assessed at an annual value of $£ 100 .^{152}$ In 1888 the Daily Telegraph wrote that the maximum of seven votes was "much too high and places far too great a power in the hands of Capital". 153 Plural voters in particular streets could outvote whole sections of the city: "Take the voting power .... of St. John Street and see how it swamps Inveresk; of Charles Street and see how it overpowers the Sandhill. In a word the existing system means the representation of Property to the ignoring of the privileges of Man". The Daily Telegraph regarded "the abnormal preponderance of property" on the Launceston Corporation as out of touch with the democratic tendencies of the period. ${ }^{154}$

Municipal reformers could not reach a consensus on how far to reduce plural voting. In August 1892, at a meeting of the Launceston Municipal Reform League, a lively discussion brought out the differences. 155 Some members demanded one man one vote in each ward but others thought that such an extreme stand would imperil any reform at all and the meeting voted for a maximum of three votes. The Daily Telegraph felt that a reduction to three votes was too ambitious and preferred a more moderate reduction to five votes. ${ }^{156}$ The Tasmanian Democrat advocated one man one vote at municipal and Parliamentary elections. ${ }^{157}$ The justification

152. Launceston Corporation Act 1858.

153. D.T. 18 December 1888.

154. Ibid 6 November 1890.

155. Ex. 17 August 1892.

156. D.T. 13 June 1895.

157. T.D. 6 February 1892. 
$76 a$.

TABLE 5 : SCALE OF VOTING AT LAUNCESTON MUNICIPAL ELECTIONS

1) Hobart Town and Launceston Municipal Councils Act 1852

1 vote for an annual value of $\$ 10$ and under $\$ 50$

\begin{tabular}{|c|c|c|c|c|c|c|c|}
\hline votes & $"$ & $"$ & $"$ & $"$ & $" £ 50$ & $"$ & $"$ \\
\hline$"$ & $"$ & $"$ & $"$ & $"$ & " £100 & $"$ & $"$ \\
\hline$"$ & $"$ & $"$ & $"$ & $"$ & $" £ 20$ & d & er \\
\hline
\end{tabular}

2) Launceston Corporation Act 1858

1 vote for an annual value of $£ 10$ and under $£ 50$

2 votes " " " " $\quad$ " " " £ 100

3 " " " " "

4 " " " " " 1150 " "

5 " " " " "

6 " " " " " $£ 250 "$ " " $£ 300$

7 " " " " $£ 300$ and over.

3) Launceston Corporation Act 1869

1 vote for an annual value of $£ 8$ and under $£ 40$

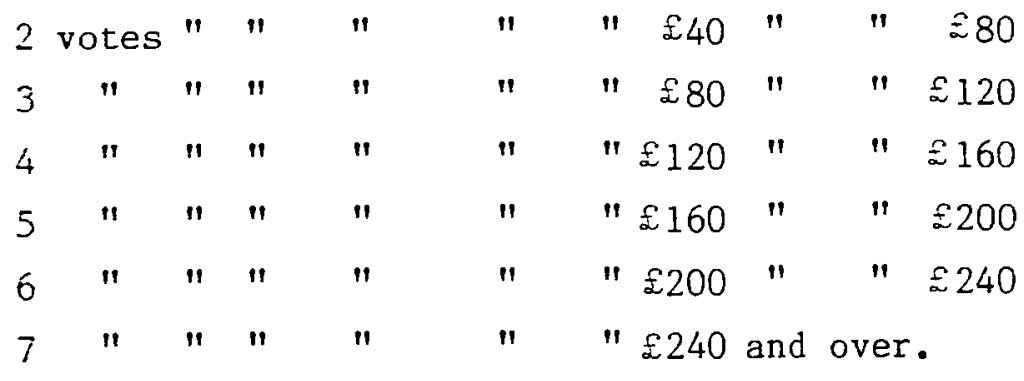

4) Launceston Corporation Act 1900

1 vote for an annual value of $£ 8$ and under $\_30$

\begin{tabular}{|c|c|c|c|c|c|c|c|c|}
\hline 2 votes & $"$ & $"$ & " & $"$ & $"$ & $£ 30$ & $"$ & " \\
\hline$"$ & $"$ & $"$ & $"$ & $"$ & $"$ & $£ 60$ & $"$ & $"$ \\
\hline$"$ & $"$ & $"$ & $"$ & $"$ & $"$ & $£ 100$ & $"$ & $"$ \\
\hline$"$ & $"$ & $"$ & $"$ & $"$ & $"$ & $£ 150$ & and & over \\
\hline
\end{tabular}

Source: G.H. Knibbs, Local Government in Australia, (Melbourne, 1919), p.136-7, 143. 
for one man one vote at municipal elections was that

Modern legislation all tends towards ratepayers having only one vote, because the poorest citizens own health, and the health of his wife and family are as dear to him and his as it is to the wealthiest ratepayer .... as good sanitation is, or should be, the chief care of our city fathers, it should follow that those who are most deeply interested should have at least an equal say in the election of those whose principal duty will be the care of the city sanitation. 158

Thus a reduction in plural voting might result in greater attention being given to public health. The Tasmanian Democrat also accused landlords of deliberately failing to pay rates for the houses they owned and thus tenants, even though they had paid their rent, were disenfranchised: "scores of working men" lost the right to vote. ${ }^{159}$ Workers were unable to stand for alderman under the present law and the Tasmanian Democrat demanded an end to "this monstrous embargo". 160

Reformers made no gains until 1894 when the Launceston Corporation Act was passed: its most notable provision was to reduce the qualification for alderman from $£ 100$ to $£ 50$ assessment on annual value. In 1894 the cause of reform was aided by the election of three liberal aldermen. In September Peter McCrackan, a public servant who later built up an ironmongery business, beat Alex Fowler at an extraordinary election. ${ }^{161}$ McCrackan wanted reform in municipal finances and was well-known as a democrat, believing

158. Ibid 16 July 1892.

159. Ibid 19 December 1891.

160. Ibid 28 January 1893.

161: Ex. 25 September 1894. 
that the essence of local government was "government of the people by the people". 162 In December 1894 R.J. Sadler and David Storrer, both advocating economy and receiving support from the Progressive Liberal Association, were elected. ${ }^{163}$ Sadler and Storrer assisted Abraham Barrett and McCrackan in re-organizing the Corporation's finances: they also helped McCrackan and subsequent liberalminded aldermen make the Corporation more representative. The attempts at liberal reform exposed the fragility of the unity that had emerged on attitudes towards economy. The conservative Examiner supported Barrett, McCrackan, Storrer and Sadler for lowering rates and particularly for tightening accounting procedures but opposed the attempts of the last three at democratic reform. The Daily Telegraph criticised the same aldermen for their policies on finance but supported their efforts at reducing plural voting. The Tasmanian Democrat encouraged the liberal aldermen "In the hard fight for pure, efficient, economical'government" and to liberalise the Corporation. ${ }^{164}$ Political differences tended to be blurred by attitudes towards financlal management but were manifest when democratic reform of municipal government was attempted.

In January 1895 Storrer was successful in having Corporation meetings held at night to allow the public to attend. 165 In May Sadler unsuccessfully tried to open eligibility to election as alderman to all ratepayers and to secure one man one vote at municipal elections. ${ }^{166}$ In July Peter McCrackan, as Acting Mayor, convened a public meeting to canvass amendments to the Launceston

162. Ibid- 19 November 1895; T.D. 9 November 1895; Cl. 7 May 1904 called McCrackan "an advanced Democrat".

163. Ex. 8 December 1894; Reynolds, "The Island Colony ....", op.cit., p.238 described the leaders of the Progressive Liberal Association as "middle class liberals" whose moderate aims secured electoral success.

164. T.D. 13, 21 December 1894, 29 November 1895.

165. Ex. 15 January 1895.

166. Ibid 7 May 1895. 


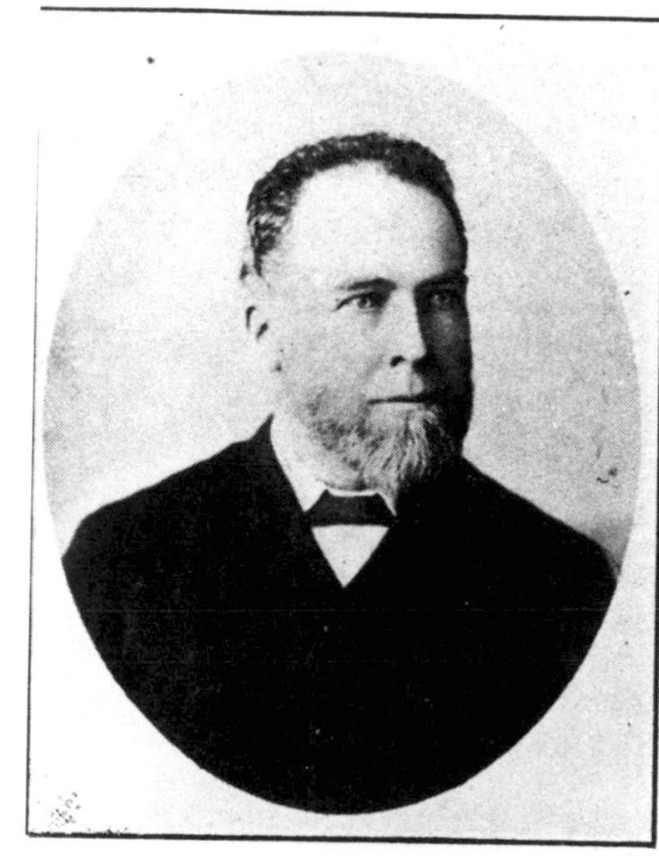

W. H CARL BURROWS CO. LAUNCESTON Mr. P'. McCracken.

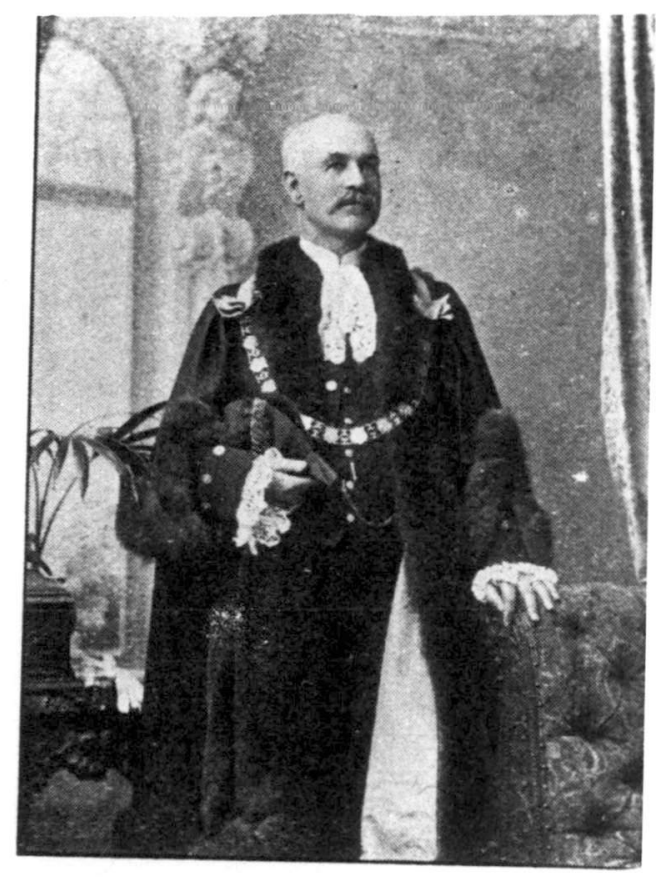

LOUIS KONRAD

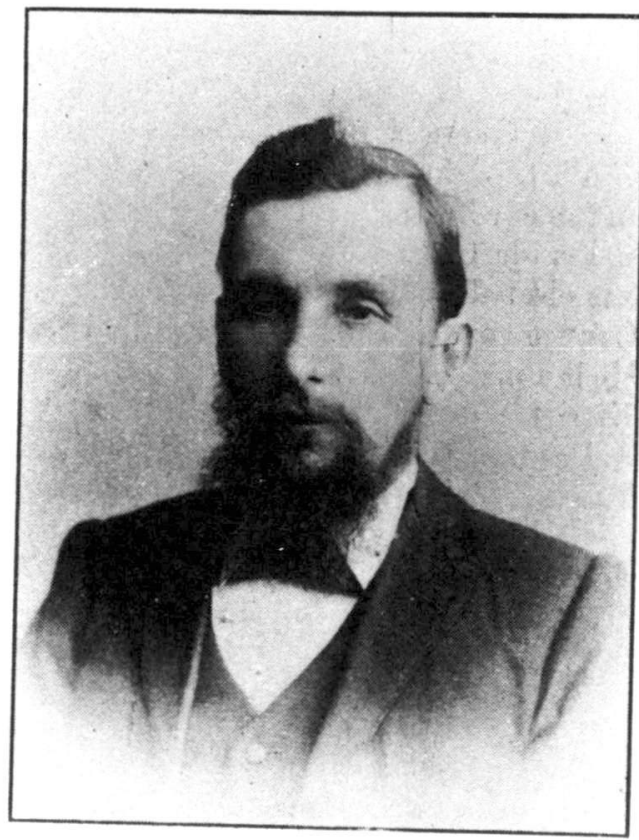

EDEN

SOCIETY STUDIOS

Mr. I). Stomber 
Corporation Act. ${ }^{167}$ John Shepherd, a leading light of the Progressive Liberal Association, acknowledged the concession made in 1894 but claimed that "the cardinal principle of municipal institutions was that all classes should be equally represented, that the social privileges of citizenship should be spread over all, and that every respectable ratepayer should claim an aldermanic qualification". The meeting voted for the right of every ratepayer to be eligible for aldermanic honours and the reduction of plural votes to three. The Examiner was sceptical of altering the franchise. 168 As "all rates are levied on a property basis", large property owners were entitled to have strong voting power and, it asserted, at present the single and double voters "if there was unity .... could return almost any Alderman they like". In theory, assuming that the interests of these voters differed from larger property owners, this was true. In the 1894 election 357 voters with between three and seven votes could muster a total of 1508 votes compared with 2831 single and double voters with a total of 3295 votes. That men like McCrackan, Sadler and Storrer were elected under the existıng restrictive franchise added weight to the Examiner's contention. Thus the Examiner believed that "the balance of power is very equally maintained... and any attempt to greatly disturb it is likely to lead to serious consequences". What the "serious consequences" would be was left to the imagination of readers but it did not deter the now liberal Launceston Corporation from seeking a reduction in plural voting. In September it sponsored the Launceston Corporation Amendment Bill 1895, clause eight of which limited plural votes to four. 169 While

167. Ibid 30 July 1895.

168. Ibid 31 July, 13 August 1895.

169. Ibid 13 September 1895. 
sympathetic, the House of Assembly altered the clause to give owners of property rated at $£ 200$ and over five votes. Despite this mild alteration the Bill was decimated in the Legislative Council, the graveyard of so much liberal legislation: the House of Assembly's amended plural voting clause and seven other clauses were struck out without discussion. ${ }^{170}$ This response disheartened reformers: it appeared an insuperable task to liberalise the Corporation while the Legislative Council held "sway and has power to insist. upon the supreme rule of purse and pocket"..$^{171}$ It was not lintil 1899 that a determined assault was made on plural voting. In January, at the annual conference of the Hobart and Launceston Corporations, a motion by Storrer to limit plural voting to five was passed. 172 A clause based on the motion was embodied in the Launceston Corporation Amendment Bill 1899 and, passed by the Assembly, was again rejected by the Legislative Council by eight votes to four, on a motion by Adye Douglas, a stalwart of the Launceston Corporation for about 30 years. ${ }^{173}$ The Daily Telegraph likened the Legislatıve Council to President Kruger of South Africa because of the way it turned "a deaf ear to all proposals for reform". 174

The pallid excuse used by the Legislative Council to discard the clause was that only four aldermen from Launceston attended the conference, which was held in Hobart. In 1900 the municipal conference was held in Launceston and the five vote maximum was reaffirmed. ${ }^{175}$ In November a Bill almost identical to the one defeated in 1899 was resubmitted toParliament. ${ }^{176}$ The reduction

170. Ibid 9 October 1895.

171. T.D. 9 November 1895 .

172. D.T. 26 January 1899.

173. M. 23 September, 23 November 1899.

174. D.T. 24 November 1899.

175. Ex. 20 February 1900.

176. Ibid 13 November 1900. 
to five votes was received enthusiastically by the House of Assembly, which four months earlier had accepted manhood suffrage to elect its own members, and some members, Edward Braddon being the most prominent, sought a further reduction. Braddon argued that, as the principle of one man one vote had been introduced for Parliamentary elections, a reduction to three votes was justified. McCrackan, elected to the Assembly in March 1900, supported Braddon but wanted one man one vote, as applied in the London County Council elections. Finally three votes for owners of property assessed at $£ 160$ and over was endorsed by the Assembly, now strongly democratic in tendency, on the motion of Premier Elliott Lews. ${ }^{177}$ The keen support given to the reduction by members of the House of Assembly influenced debate in the Legislative Council. The action of Lewis particularly affected the Chief Secretary George Collins, member for Tamar and Adye Douglas's legal partner, who had consistently opposed alteration of the municipal franchise. Collins could not entirely oppose Lewis's motion but he did succeed in raising the minimum number of votes to five. ${ }^{178}$ (Table 5) The Examiner claimed that no plausible arguments had been advanced in favour of the change: it was "one of the manias of this democratic age to reduce everything to a dead level". ${ }^{179}$ The Launceston Corporation Act 1900 also ensured that occupiers of properties were not disenfranchised by the owner's failure to pay rates. The municipal franchise aroused little concern between 1901 and 1914. In late 1905 the Launceston branch of the Workers'

177. M. 17, 19 November 1900; Reynolds, "The Island Colony ...", op.cit., p.112-13 noted that federation greatly influenced the House of Assembly to vote for manhood suffrage.

178. M. 6 December 1900.

179. Ex. 15 November 1900. 
Political League drew up a municipal platform containing 17 planks. 180 The abolition of plural voting was the first plank. Three candidates were supported by the Workers' Political League at the municipal elections in December. ${ }^{181}$ Tas Shields and L.J. Bryant were defeated: Charles Russen topped the poll and became Mayor in 1906 but he appears not to have used his position to secure the abolition of plural voting. ${ }^{182}$ The interest shown by the Launceston Corporation in the welfare of the city left little scope for the Workers' Political League and its influence in municipal life was negligible.

Apart from efforts to reduce plural voting, the attack on property owners never approached the ferocity that it did in Hobart. In 1893, during the depression, the Iasmanian Democrat accused some landlords of being "Shylock, in his worst aspect" for callously ejecting tenants who could not pay rent. 183 "Men and women", fulminated the Tasmanian Democrat, "deny themselves the necessaries of life in order that the rent may be paid. Failing this, the .... owner disposes of their few belongıngs, and turns them, houseless and possessionless into the street". This was one of few such attacks. In 1901 the Hobart and Suburban Property Owners' Association was formed. In March 1902 the President of this Association, George Seabrook, addressed a meeting of Launceston property owners and urged "a united feeling in all matters appertaining to property". ${ }^{184}$ At the meeting the Launceston City and Suburban Property Owners' Association was set up, with Samuel Sutton

180. Cl. 11 November 1905.

181. Ex. 5 December 1905.

182. At least one of these candidates Tas Shields denied that he favoured the abolition of plural votung see his letter in D.T. 7 December 1905.

183. T.D. 4 November 1893.

184. Ex. 11 March 1902. 
as President, but it appears to have only lasted just over a year. ${ }^{185}$ As property interests were rarely under threat in Launceston, and as tenants rarely caused trouble, there was little need for property owners to combine.

There is little doubt that the Launceston Corporation played a leading role in the city. It was responsive to the needs of citizens and judiciously invested money, borrowed or derived from rates, for their benefit. Without a progressive Corporation Laun ceston would not have gained the electric light scheme or the trams when it did. A desire to make Launceston a pleasant place in which to live, combined with civic pride, were key impulses to the extension of municipal powers. Those seeking municipal reform did not dispute the Corporation's right to provide a range of services: most reformers wanted the Corporation to provide more services. Swept along by the liberal tide of the 1890s, they sought to democratise municipal government, not to reduce its functions. An absolutely crucial function was to safeguard the public health and we are about to see how well it was discharged.

185. Ibid 25 April 1903 records the last meeting that has been found. A deputation of members did surface in September 1905 to protest to the Treasurer against the Legal Process Restriction Policy Bill. Ex. 19 September 1905; for Property Owners' Associations in Britain see D. Englander, Landlord and Tenant in Urban Bratain 1838-1918, (Oxford, 1983), Chapter 4. 


\section{CHAPTER THREE}

\section{THE CITY HEALTH DEPARTMENT}

Rivalry between Launceston and Hobart was keen in the nineteenth century and dominated many aspects of inter-city relations. The appearance of epidemic diseases in the 1880s and 1890 s fostered and accentuated this rivalry: each city claimed to be healthier and less affected by disease than the other. Editorials in northern and southern newspapers portrayed their respective cities in a favourable light and exchanged criticisms of the sanitary condition of their respective cities. In November 1892 the Examiner wrote that

$$
\begin{aligned}
& \text { With the return of the summer season and the } \\
& \text { advent of visitors from the mainland has come } \\
& \text { the old, old story from the south lauding the } \\
& \text { savoury city on the Derwent and detracting from } \\
& \text { the healthfulness of the northern capital. }
\end{aligned}
$$

The southern critic, the Mercury, pointed out that in the last four years 673 cases of typhoid fever had occurred in Launceston but in Hobart, with a larger population, only 616 cases were recorded. (Table 6) The Examiner's rejoinder was that all typhoid cases in Northern Tasmania were attributed to the city of Launceston, while the various towns around Hobart had typhoid notifications separately recorded. Specifically, the statistics for Launceston were taken from an area 50 miles long and 20 miles wide: the city proper was only 3,400 acres in area. ${ }^{2}$ In Hobart the area did not extend further than 5 miles in any direction. The Examiner concluded that "The mere distortion of facts relating to the northern capital will

1. Ex. 19 November 1892 .

2. Ibid 25 September 1891. 
TABLE 6 : CASES OF INFECTIOUS DISEASES NOTIFIED IN HOBART (H) AND LAUNCESTON (L).

\begin{tabular}{|c|c|c|c|c|c|c|c|c|}
\hline \multirow[b]{2}{*}{ Year } & \multicolumn{2}{|c|}{ Typhoid } & \multicolumn{2}{|c|}{ Diphtheria } & \multicolumn{2}{|c|}{ Scarlet Fever } & \multicolumn{2}{|c|}{ Total } \\
\hline & $\mathrm{H}$ & $\mathrm{L}$ & $\mathrm{H}$ & $\mathrm{L}$ & $\mathrm{H}$ & $\mathrm{L}$ & $\mathrm{H}$ & $\mathrm{L}$ \\
\hline 1888 & 149 & 190 & 18 & 31 & 60 & 144 & 227 & 365 \\
\hline 1889 & 184 & 291 & 12 & 43 & 16 & 47 & 212 & 381 \\
\hline 1890 & 86 & 105 & 6 & 33 & 1 & 8 & 93 & 146 \\
\hline 1891 & 197 & 87 & 5 & 18 & 2 & 3 & 204 & 108 \\
\hline 1892 & 78 & 54 & 82 & 12 & 7 & 19 & 167 & 85 \\
\hline 1893 & 62 & 44 & 49 & 21 & 4 & 7 & 115 & 72 \\
\hline 1894 & 95 & 47 & 36 & 8 & 2 & 7 & 133 & 64 \\
\hline 1895 & 116 & 101 & 20 & 9 & 1 & - & 137 & 110 \\
\hline 1896 & 80 & 46 & 45 & 3 & 4 & 1 & 129 & 50 \\
\hline 1897 & 116 & 55 & 30 & 4 & 20 & 32 & 166 & 91 \\
\hline 1898 & 293 & 65 & 8 & 13 & 49 & 56 & 350 & 134 \\
\hline 1899 & 64 & 14 & 12 & 1 & 312 & 23 & 388 & 38 \\
\hline 1900 & 63 & 34 & 4 & 29 & 67 & 7 & 134 & 70 \\
\hline 1901 & 69 & 33 & 10 & 8 & 59 & - & 138 & 41 \\
\hline
\end{tabular}

Source: Central Board of Health Annual Reports.

TABLE 7 : CASES OF INFECTIOUS DISEASES IN PARTS OF LAUNCESTON

\begin{tabular}{|l|r|r|r|r|r|r|r|c|}
\hline Localities & \multicolumn{7}{|c|}{ Rates Per 1000} \\
\hline & 1888 & 1889 & 1890 & 1891 & 1892 & 1893 & 1894 & 1895 \\
Inveresk & 12.5 & 42.0 & 11.0 & 6.6 & 13.2 & 10.1 & 7.0 & 19.1 \\
Galvin Town & 17.1 & 12.8 & 9.2 & 5.6 & 2.8 & 0 & 1.0 & 2.0 \\
Windmill Hill & 41.3 & 13.1 & 6.8 & 6.5 & 4.7 & 4.7 & 1.7 & 1.7 \\
*Block & 20.7 & 19.5 & 4.2 & 1.2 & 2.4 & 3.6 & 3.6 & 1.7 \\
\hline
\end{tabular}

* Bounded North by Brisbane Street; South by Elizabeth Street; East by Charles Street; West by Margaret Street.

Source: Ex. 3 December 1895. 
not improve the condition of affairs at the southern one and it needs no reference to statistics to prove that they are capable of very considerable improvement". ${ }^{3} \quad$ Launceston's healthy state was due, claimed the Examiner, to sanitary improvements as "simultaneously with the extension of our sewerage system and enforcement of sanitary regulations there has been a steady decline in typhoid and other zymotic diseases". 4 From 1888 to 1895 of the localities such as Inveresk, Galvin Town, Windmill Hill and the Block, "the most unhealthy in the city", all except Inveresk had experienced major reductions in the incidence of zymotic diseases. ${ }^{5}$ (Table 7) The Launceston Corporation had achieved these results by its own efforts while in Hobart there was a Municipal Council, Central Board of Health, Metropolitan Drainage Board, Komen's Sanitary Association "and sundry other associations, and yet between them all they are not able to keep the city drains and sewers in a decent condition". 6

The Daily Telegraph was less prone to praise the sanitary work of the Corporation, particularly in the 1880 s when it blamed the appearance of typhoid on the neglect of drains and streets in outlying suburbs. ${ }^{7}$ As sanitary improvements lowered the death rate, the Daily Telegraph came to uphold the salubrity of Launceston, "one of the sanitoriums (sic) of the Southern Hemisphere". 8 In

3. Ibid 19 November 1892.

4. Ibid 25 September 1891.

5. Ibid 3 December 1895.

6. Ibid 19 February 1896.

7. D.T. 11 March 1889.

8. Ibid 8 April 1889. 
1898 it noted that since 1889 the general death rate of Launceston had decreased each year and in 1897 it was 12.37 per 1000: Hobart's death rate was 16.95 per $1000 .^{9}$ 'l'he tact, wrote the Daily Telegraph, that Launceston had "an unlimited supply of pure water and at least some kind of a sewage system, while Hobart has only half a water system and no sort of sewage system at all" helped "to explain why there is such a statistical difference in favour of Launceston from a health point of view". As we shall see, in Hobart statistics were produced to controvert claims that the death rate in Hobart was high and that Launceston was healthier, but however statistics were interpreted, it is true that the commitment of the Launceston Corporation to sanitary improvement was greater than the Hobart Corporation and that no sanitary movement, such as developed in Hobart, appeared in Launceston. The appointment of a Health Officer in 1875 was one initiative where the Hobart Corporation took the lead: in Launceston, while Bushman was appointed in 1883, a Health Officer was not appointed until 1896. However the support given by Launceston aldermen to their health officials resulted in the achievement of much practical sanitary work, while in Hobart aldermen obstructed rather than assisted the Health Officer, especially in the period 1875 to about 1903. This chapter will study the work of Bushman and the Health Officers of the Launceston Corporation.

Under the Public Health Act 1885 the aldermen of the Launceston Corporation were required to form a Local Board of Health. Bushman as Sanıtary Officer remained in charge of the Sanitary department on a full-time basis and had a degree of autonomy in

9. Ibid 10 March 1898. These figures are at odds with the figures in the Statistics of Tasmania, which gives the city of Launceston a death rate of 13.02 per 1000 and the city of Hobart 12.92 per 1000 . 
carrying out his daily work but major policy decisions were

ultimately made by aldermen. In his reports Bushman not only described what had been done but pointed to improvements that were required. According to Wohl, Health Officers in England "with their highly specialized education and increasing competence in preventive medicine, gave local government in the second half of the nineteenth century an authority and expertise hitherto lacking, and they supplied a lead in the agitation for, and administration of, sanitary legislation ...."10 Bushman did not have this training but he read widely and kept abreast of developments in sanitation, of ten quoting authorities in his reports. In June 1886 new by-laws were drawn up to regulate the removal of house refuse, drainage and plumbing, water and earth closets, the storage of offensive matter, dairies and cowkeepers, bakehouses, butchers and fishmongers. ${ }^{11}$ Bushman worked diligently under the powers provided by the Public Health Act and in the first 6 months issued 1123 notices for various improvements. ${ }^{12}$ House to house visits remained the foundation of Bushman's sanitary work but were more difficult in Launceston than in Hobart because Launceston embraced a larger area and houses were more scattered. Bushman, however, covered much territory with the help of his Inspector of Nuisances William Murnane. Raised in Longford, Murnane was an ex-policeman and an honest servant of the Corporation for over 40 years. ${ }^{13}$ His "tactfulness and quiet and unassuming disposition gained him many friends amongst all sections of the community". Bushman's half

10. A.S. Wohl, "Unfit for Human Habitation" in H.J. Dyos and M. Wolff (eds.), The Victorian City: Images and Realities, (London, 1973), v.2, p.603; for the work of Health Officers in Sydney see A.J.C. Mayne, Fever, Squalor and Vice: Sanitation and Social Policy In Sydney, (St. Lucia, 1982), Part 2, and in Milwaukee see J.W. Leavitt, The Healthiest City: Milwaukee and the Politics of Health Reform, (Princeton, 1982), Chapter 2.

11. Hobart Gazette 22 June 1886, p.987-8,

12. Ex. 2 November 1886.

13. Ibid 17 May 1924. 
yearly report was lauded by the Central Board of Health because it showed the "spirit and intelligence" with which he used the new legislation and the result was genuine sanitary improvements. ${ }^{14}$

Despite these improvements Bushman's unpopularity amongst ratepayers was not lessened. In May 1886600 burgesses petitioned the Council, complaining about Bushman. ${ }^{15}$ Alderman David Scott moved that the Sanitary department be dissolved and a Health Officer appointed. Samuel Sutton noted that there was not "good feeling between the Sanitary Officer and the burgesses", and as the Public Health Act required the Corporation to appoint a Health Officer, now was an opportune time to dismiss Bushman. Henry Button praised Bushman's work. When Bushman was appointed Launceston "was in as filthy a condition as any large town in Australasia" and he had carried out "as well as he possibly could the duties of a necessarily unpopular office". However, to comply with the Health Act, Button suggested that Bushman be given 12 months notice and that the Corporation secure from England "a man who has received a proper education on sanitary matters". 'Robert Carter, an influential alderman, stoutly defended Bushman who had come under attack because he discharged "the duties of his office fearlessly and independently and by so doing had trodden on the toes of some who did not like it", including some aldermen. The motion was defeated.

Bushman's position had been preserved but the Corporation had to address itself to the provisions of the Health Act. In June Carter proposed a compromise. ${ }^{16}$ He suggested that Dr. R.W. Murphy, who attended to the municipal police force, be asked to act as Health Officer until the Health Act could be amended to allow
14. T.P.P. $1886 / 92$.
15. Ex. 4 May 1886.
16. Ibid 15 June 1886 . 
Bushman to carry out the duties of Health Officer. To employ a doctor as a full-time Health Officer, argued Carter, would cost between $£ 400$ and $£ 500$, which the Corporation could not afford. Bushman was paid $£ 250$ per annum. Carter's argument held sway and Murphy accepted the post at a salary of $£ 25.17$ Thus Murphy was nominally Health Officer and was available to provide advice on public health issues but Bushman administered the Health department. The Public Health Amendment Act 1887 contained a clause that enabled Bushman to fulfil the duties of Health Officer and Murphy's appointment ended soon after.

Bushman's work was negatived to some extent by the failure of the towns surrounding Launceston to enforce sanitary regulations. In June 1887 a typhoid outbreak in St. Leonards highlighted the danger to Launceston. ${ }^{18}$ The Examiner thought one solution was for the Government to appoint a Health Officer for the North and the South: the salaries would be shared by the Government and the municipalities in each area. The 1887 smallpox epidemic gave weight to the arguments that full-time medical supervision was needed in Launceston and the North. ${ }^{19}$ Bushman was placed in a precarious position. His opponents argued that if a doctor had been Health Officer the detection of smallpox, if not its prevention, would have been much quicker. During the municipal elections of December 1887 feeling against Bushman was very high. Writing to the Examiner, "A Citizen" criticized past aldermanic candidates for failing to adhere to their electoral

17. Ibid 22,29 June 1886.

18. Ibid $1 \mathrm{July} 1887$.

19. M. Roe, "Smallpox in Launceston, 1887 and 1903", T.H.R.A., v.23, 4, 1976, P.111-48. 
90.

pledges and dismissing Bushman. 20 Bushman's personality was criticised. He was" "next to unapproachable", found "it the greatest effort to be commonly courteous", was "overbearing", "most offensive to others in the discharge of his duties" and, worst of all, the public were "afraid to express their real grievances for redress for fear of annihilation on the spot". Bushman's military experiences in India had left their mark but Bushman was unwise to treat the residents of Launceston in the supercilious and inflexible way he might have treated his subordinates or the natives of India.

On 5 December about a 1000 people attended a meeting to hear the views of aldermanic candidates. ${ }^{21}$ According to the Daily Telegraph Bushman was "the bête noir of the meeting", although the retiring aldermen defended his work. W.F. Wathen, to whom Bushman had sent notices, was the most outspoken voice against Bushman, asking for a properly trained doctor to replacethis "Indian cow doctor", and he became "the idol of the hour". The outcome of the election showed that "the public are smarting with dissatisfaction" with the existing sanitary management. 22 Wathen had tried four times to be elected but had dismally failed: in December 1887 he topped the poll. B.P. Farrelly, who supported Bushman and was well regarded, came third, just holding onto his seat. Apart from Bushman's manner, the vote was influenced by the smallpox epidemic which, wrote the Examiner, "demonstrated beyond al1 doubt" the necessity of a doctor as Health Officer. ${ }^{23}$ Early in January 1888 the Local Board of Health waited on Premier Fysh to discuss sanitary arrangements in the North. ${ }^{24}$ Robert Carter thought Laun-

20. Ex. 1 December 1887.

21. D.T. 6 December 1887; Ex. 17 April 1889.

22. Ex. 9 December 1887.

23. Ibid.

24. Ibid 9 January 1888. 
ceston was "a credit to the colony so far as cleanliness was concerned", but there was growing public support in Launceston for the appointment of a Health Officer. Interestingly he then argued that the administration of the Health Act should "not be in the hands of any municipal body or board, .... [but] a central board entirely separated from local influence". Peter Barrett said they wanted "a man who would give his whole time to the work; who would have no private practice; whose salary would be paid by the Government". Fysh replied that to appoint two suitably qualified men as Health Officers for the North and South would cost $£ 1600$ per annum and he doubted that Parliament would give its consent. Fysh was surprised that most members of the deputation advocated "centralisation" because resistance to the Health Act since its inception indicated that "public opinion was moving in an opposite direction". Carter and Barrett might have been motivated by a desire to save money and a realistic conception of effective sanitary administration but their request was a departure from the usual anti-centralisation stance of the Launceston Corporation. Fysh, who increasingly favoured strengthening central Government powers, changed direction and placed the onus on the Local Board of Health to make its own arrangements. Further attempts were made to change the Government's mind but they were met with arguments of economy and local responsibility.

In February 1888, to stifle public demands for a Health Officer, the Council appointed Dr. W.G. Maddox to replace Murphy at a nominal fee of 210.25 Maddox held "a leading position" in his profession. 26 His duties were confined to the isolation of

25. Ibid 21 February 1888; Hobart Gazette, 28 February 1888,p.443.

26. Cyclopedia of Tasmania, (Hobart, 1900), v.2, p.332. 
houses with infectious diseases and closing polluted wells; extra payments would be made for special reports on the sanitary condition of Launceston. 27 Attacks on Bushman continued to be made but, whatever his personal deficiencies, few could cavil at his success in diminishing the incidence of disease. In April 1889, after reviewing a report on his work since 1883, the Examiner believed that "a little more tact or suavity at times" might have made Bushman's "task smoother" but "the energy, ability and firmness he has exhibited ... have now won the respect and confidence not only of the aldermen but the majority of burgesses". ${ }^{28}$ His report "gave some striking figures of the practical benefits" of sanitary work but "conveyed no idea of the persistent opposition, misrepresentation and abuse that has been encountered from 1884 to the present time". Wathen had initiated or was involved in most of these attacks on Bushman. In May 1889 he tried once more to replace Bushman with a doctor but failed to receive support from other aldermen. 29 Resentment towards Bushman diminished somewhat in the following years. In April 1893 his duties were augmented when, because of his veterinary training, he was appointed to replace the retiring Inspector of Stock. 30

In its annual report of 1894 the Central Board of Health noted that the sanitary work of the Launceston Corporation was "quite unique in Tasmania, and, we believe, in the Australian colonies, so far as preventible diseases are concerned". 31 From 1889 to 1894 there was a "constant and uninterrupted diminuition" in the number of cases of preventible diseases from 381 to 64 .

27. Ex. 20 March 1888.

28. Ibid 17 April 1889.

29. Ibid 28 May 1889.

30. Ibid 6, 18 April 1893; Hobart Gazette, 25 April 1893, p.855.

31. T.P.P. 1895/20. 
This achievement was "almost entirely due to the unremitting zeal and determination of Mr. Bushman". Bushman's success should have secured his position as Sanitary officer but it did not. In 1895, as was noted in the last chapter, the economy aldermen were gaining control of the Corporation. In February 1895 a report of the Finance committee recommended that the Health department be abolished, that the provisions of the Health Act be enforced by the police or as the Corporation directed and that Bushman be dismissed. 32 These recommendations united those who were bitter opponents in the heated atmosphere that prevailed in 1895. The Examiner argued that the value of Bushman's services were "evident in the improved state of the health of the city and it would be a doubtful piece of economy to risk a lapse into former conditions for the sake of the amount paid for his services". 33 The Examiner's rival the Daily Telegraph also attested to. the improvements made under Bushman's regime. 34 The Tasmanian Democrat regarded the proposals as "detrimental to the fair fame of the city and dangerous to its people": the alderman were approaching economy from "a personal, partial and improper standpoint". 35 Each newspaper condemned the proposal to use the police as, in the words of the Daily Telegraph, it would sound "the death-knell" of sanitation in Launceston. 36

Support for Bushman came from other quarters. At Holy Trinity Church Archdeacon Hales made "an emphatic protest" against the Finance committee's report. ${ }^{37}$ A petition to the Corporation from 10 doctors, including Maddox and Murphy, described the recommendations as "fraught with danger to the health of the citizens" and paid tribute to Bushman's "vigilant inspection and

32. Ex. 26 February 1895.
33. Ibid 28 February 1895.
34. D.T. 1 March 1895.
35. T.D. 1, 8 March 1895.
36. D.T. 4 March 1895.
37. Ex. 4 March 1895.


expert knowledge". 38 Thus Bushman's lack of medical training was not a disadvantage as far as the doctors were concerned. Finally "one of the most numerously and influentially" signed petitions, containing 768 signatures, ever received by the Corporation characterised the recommendations as "disastrous". 39 This support showed that Bushman had consolidated his standing in the eyes of the public: aldermen must have been convinced of the egregious folly of implementing the recommendations. The aldermen who supported the report acknowledged that Bushman had achieved much but ingeniously argued that the Corporation could no longer afford his services and, now that the city had reached a high level of health, Bushman was no longer needed. 40 Health Officers have been dismissed for being inefficient but rarely for being too efficient. Aldermen were evenly divided and the casting vote of the Mayor Walter Ferrall had to settle the issue. Ferrall was not a weak man but he was indecisive. Forced to decide, he voted against the dismissal of Bushman but for the abolition of the Health department. This compromise satisfied no-one and on 25 March the future of the Health department was reconsidered. ${ }^{41}$ It was moved that, as Bushman's services were to be retained, the motion abolishing the Health department was "inopportune" and should be rescinded but on 6 May the motion was defeated. ${ }^{42}$ The Examiner openly charged that personal feeling, not economic considerations, were foremost as Bushman "in the execution of his duty has come into collision with several who are now sitting in judgement upon him". ${ }^{43}$

38. Ibid 5 March 1895.

39. Ibid; D.T. 6 March 1895.

40. Ex. 5 March 1895.

41. Ibid 26 March 1895.

42. Ibid 7 May 1895.

43. Ibid 10 May 1895. 
On 14 May, feeling that he would be likely to change his vote, a deputation waited on Ferral1. 44 It comprised most of the leading religious, business and medical men of the city and included four past Mayors of Launceston. Archdeacon Hales, in an emotional plea, said that in 40 years in Launceston he had eschewed involvement in "political matters" but the future of the Health department was a question of "life and death": Ferrall, Hales continued, should use his casting vote to retain the Health department and Bushman because if he did not "and by his action caused disease and misery in the city, he would regret it to the last hour of his life". On 20 May Alderman Storrer moved that a Health Officer be appointed at $£ 100$ per annum, with the services of an Inspector of Nuisances at his disposal, but the motion was postponed until a public meeting was held. 45 On 23 May 400 people assembled at the Albert Hal1. 46 John Shepherd, who was involved in the various municipal reform bodies, moved that "this meeting approves of the efforts of Aldermen seeking to effect retrenchment in the Sanitary Department". He did not discount Bushman's contribution to the improved health of the city but denied it was due "to a large extent to him and to him only": more important was, for example, skilled nursing. Other speakers stressed the contribution of sewerage extension during the last decade and were convinced that a part-time Health Officer could maintain the present high standard of health. Shepherd's motion was passed. The Examiner placed little importance in the vote. 47 Most of those who attended the meeting were not ratepayers and the motion was "cunningly-worded" to avoid direct reference to Bushman. It was adamant that a part-time Health Officer

44. Ibid 15 May 1895.
45. Ibid 21 May 1895.
46. Ibid 24 May 1895.
47. Ibid.


would be inadequate protection from disease.

Once again Bushman's supporters rallied. 908 ratepayers and 10 doctors separately petitioned the Council against any changes to the Health department. ${ }^{48}$ Realising that the city was polarised and emotions were running high, making a rational decision improbable, Alderman Gilmore moved that "the re-organization of the Sanitary Department be postponed until after the municipal elections". Ferrall used his casting vote in favour of the motion, welcoming a reprieve from the hectic events of the past four months. The battle for Bushman and the Health department had been won but the war had not yet ended, because in February 1896 Bushman became involved in another controversy that led to his dismissal. Rumours of diseased meat at the Corporation slaughteryard prompted Alderman W.C. Wilson, a rumbustious, combative man, to demand a report from Bushman on all cases of diseased animals and meat found during December and January, an assessment of the Assistant Inspector of Stock Michael Curtin's work, and ways to improve the efficiency of the slaughteryard. ${ }^{49}$ Bushman reported that from 3 December 1895 to 31 January 189662 organs, mainly livers and lungs, contained disease of some kind, hydatids, tuberculosis or cancer. 50 One of Curtin's duties was the inspection of carcases but, alleged Bushman, he was often negligent despite "frequent admonitions": Bushman doubted Curtin's ability to identify diseased meat. The Slaughterhouse committee investigated procedures at the slaughter-

48. Ibid 4 June 1895.
49. Ibid 4 February 1896.
50. Ibid 11 February 1896.


yard. 51 It concluded that Curtin could not distinguish diseased meat from safe meat, disobeyed Bushman's orders and could be charged with dereliction of duty. The Examiner, stressing the importance of food to health, wanted the Corporation to restore public confidence in the slaughteryard by ensuring greater precautions were taken to prevent "diseased meat from passing into the hands of consumers". 52 In effect this meant Curtin's dismissal.

On 11 May, after considering the charges against Curtin and other evidence, a committee of the whole Council judged that "the charges preferred against Mr. Curtin are not proven". 53 It was recommended that the Health Officer Dr. Maddox be placed in charge of the slaughteryard and that Curtin be resident officer. The Examiner thought justice had gone awry and that "the chief object of some members .... was evidently not to enquire into the charges made against the Assistant Inspector but to prove that the Inspector knew nothing about his business". ${ }^{54}$ 'The Daily Telegraph, criticising "the partisanship" displayed by the Council, objected to Curtin as resident officer at the slaughteryard because his own evidence proved "conclusively that he is totally unfitted for such a responsible position". 55 It was later reputed that a carcase Bushman had condemned, but passed as edible by Curtin, was partly owned by Alderman Ferrall and that Storrer's brother had a beast condemned by Bushman. 56 The vindictive element was again prominent.

51. Ibid $6,7,8,9$ May 1896.

52. Ibid 9 May 1896.

53. Ibid 12 May 1896.

54. Ibid 14 May 1896.

55. D.T. 15 May 1896.

56. Ex. 19 May 1896. 
Citizens who had supported Bushman in 1895 again sprang to his defence, with a deputation to the new Mayor Peter McCrackan and further petitions: the doctors once more emphasised the danger to health the proposed arrangements would present. 57 In 1895 consideration of the petitions had delayed Bushman's opponents long enough to force second thoughts: this time the petitions were blatantly disregarded. The Corporation was no longer evenly divided and Bushman's enemies were in the majority. They moved quickly. On 18 May aldermen decided that Bushman's services would be dispensed with, the City Surveyor or police would perform the duties of Sanitary Officer and the Health Officer would take over the duties of Inspector of Stock. Bushman was given leave of absence by the Mayor, which amounted to his dismissal, until re-arrangements were completed. 58 W.C. Wilson valiantly tried to save Bushman but without success. 59 The clique opposed to Bushman resisted attempts to force a reconsideration of his dismissal. In June Maddox, who had supported Bushman, resigned and applications were sought for the position of Health Officer. 60 Three applications were received: Doctors J.T. Wilson, L.S. Holmes and C.A. Hogg. 61 Holmes and Hogg were two of the doctors who had sided with Bushman and this jeopardised their chances. Wilson, who shared the political views of the liberal aldermen, was appointed.

That Wilson's appointment was decided quickly, with no debate on his merits, aroused the censure of the press. When the City

57. Ibid.

58. Ibid 21 May 1896.

59. Ibid 23 May 1896.

60. Hobart Gazette, 11 August 1896, p.1364.

61. Ex. 9 June 1896. 
Electrician was appointed, some aldermen now in power but then in the minority, wanted his duties clearly defined. The same aldermen, wrote the Examiner, appointed a Health Officer, at a yearly salary of $£ 150$, with "no conditions imposed, no duties laid down": he could do "practically as he likes". ${ }^{2}$ The Daily Telegraph noted how "by stifling discussion, refusing further consideration and in a most coercive manner, the Mayor and his followers appointed an Officer of Health, without the Council, the public, or the officer appointed, having any fixed basis of agreement to show what duties are to be performed ...."63 The public protested as they had in 1895 and a new ally appeared when the Central Board of Health intervened on Bushman's behalf: it asked why the management of the slaughteryard and Health department was being re-organized. 64 The Council was slow in sending detailed information and the Central Board refused to sanction Wilson's appointment until this was sent. 65 After receiving the details requested. some members of the Central Board of Health voiced displeasure with the circumstances leading to Bushman's dismissal but they did not have the legislative power to reinstate him. In August, with no other choice, it approved of Wilson's appointment, but felt "it to be its duty in the public interest to record its regret that the Sanitary Officer (Mr. Bushman), who had so faithfully and with such good results served your board, has been dismissed". 66 Disturbed that Curtin would be responsible for the inspection of meat, the Local Board was asked "to reconsider the position". This was a forlorn hope: the aldermen remained immovable.

62. Ibid 10 June 1896.

63. D.T. 10 June 1896.

64. Ex, 12 June 1896 for a public meeting in support of Bushman, $\underline{\underline{\mathrm{Ex}}} \mathbf{} 23$ June 1896.

65. M. 25 June 1896; Ex. 7 July 1896.

66. M. 5 August 1896; Ex. 18 August 1896. 
On 7 September, at a meeting of sympathizers, a presentation was made to Bushman containing 662 signatures and a purse of sovereigns, a common appreciation for men who had performed exceptional public services for the city. 67 Aldermen were criticized for their "highhanded action" in dismissing Bushman "without sufficient reason - ... without any complaint and in the face of a strong public protest" and "more on account of private than public grounds". The Central Board of Health had failed to save Bushman but it wanted to stop similar incidents of arbitrary dismissal in the future. The Public Health Amendment Bil1 1896 provided that no Sanitary Officer or Inspector of Slaughterhouses could be appointed or removed without the approval of the Central Board of Health. The clause received no support from the Launceston press. They argued that as local boards paid the salary of their officials, they should have the right to determine the conditions of service. ${ }^{68}$ Similar points were made during debate on the clause in the House of Assembly and it was rejected on the voices. 69

Bushman's reign as Sanitary Officer indicated the pressures and sensitivities of that office. It demonstrated the undesirability of locally appointed health officials, as they were too subject to the vagaries of the political process. Aldermen were too susceptible to the demands of electors, who might be alienated by the enforcement of unpopular and costly sanitary laws. If aldermen themselves trangressed these laws, a health official would be reticent to serve notices on them. As the Daily Telegraph wrote, the most important qualification of a Sanitary Officer,was to be "completely

67. Ex. 8 September 1896.

68. Ibid 30 September 1896; D.T. 2 October 1896. 69. M. 7 October 1896. 
independent of local control and influence, and not to be subservient to the whims of sisters, cousins and aunts of Aldermen and aspirants for municipal honours". 70 To Bushman's credit he never, or rarely, compromised his impartiality and even aldermen could not escape his vigilant eye. The surprising fact about Bushman was not that he was dismissed in the way he was but that he lasted for so long. His major achievement was to clean up the city and in 1895 the death rate was 14.09 per 1000 , probably the lowest yet recorded. (Table 8) Personal malice and economy were plausible explanations why aldermen sought Bushman's dismissal but the persistence with which he was attacked bespoke a deeper motivation, linked with the turmoil experienced by the Launceston Corporation in the mid 1890s. Bushman was associated with the "old order" of aldermen and his life and training, as an army officer in India, was tainted by an authoritarian outlook that might not have fitted in with the liberal tendencies of the "new order" of aldermen. Bushman adopted a haughty demeanour when dealing with the lower classes of Launceston: the liberal aldermen, most of whom later sought election to Parliament, saw themselves as defenders of the same classes. 71 Bushman's successor, John Wilson, not only had similar political views to the liberal aldermen, but was involved in various philanthropic bodies and was sympathetic to the plight of the have nots. 72 John Thomas Wilson, a Catholic, was born in Westbury in 1868. 73 Educated at the Launceston Church Grammar School, Wilson was a brilliant student, winning all the scholarships offered by the Council

70. D.T. 26 March 1889.

71. McCrackan and Sadler were elected to the House of Assemb1y in 1900 and Storrer in 1902.

72. Roe, op.cit., p.128.

73. Cyclopedia of Tasmania, op.cit., v.2, p.95. 


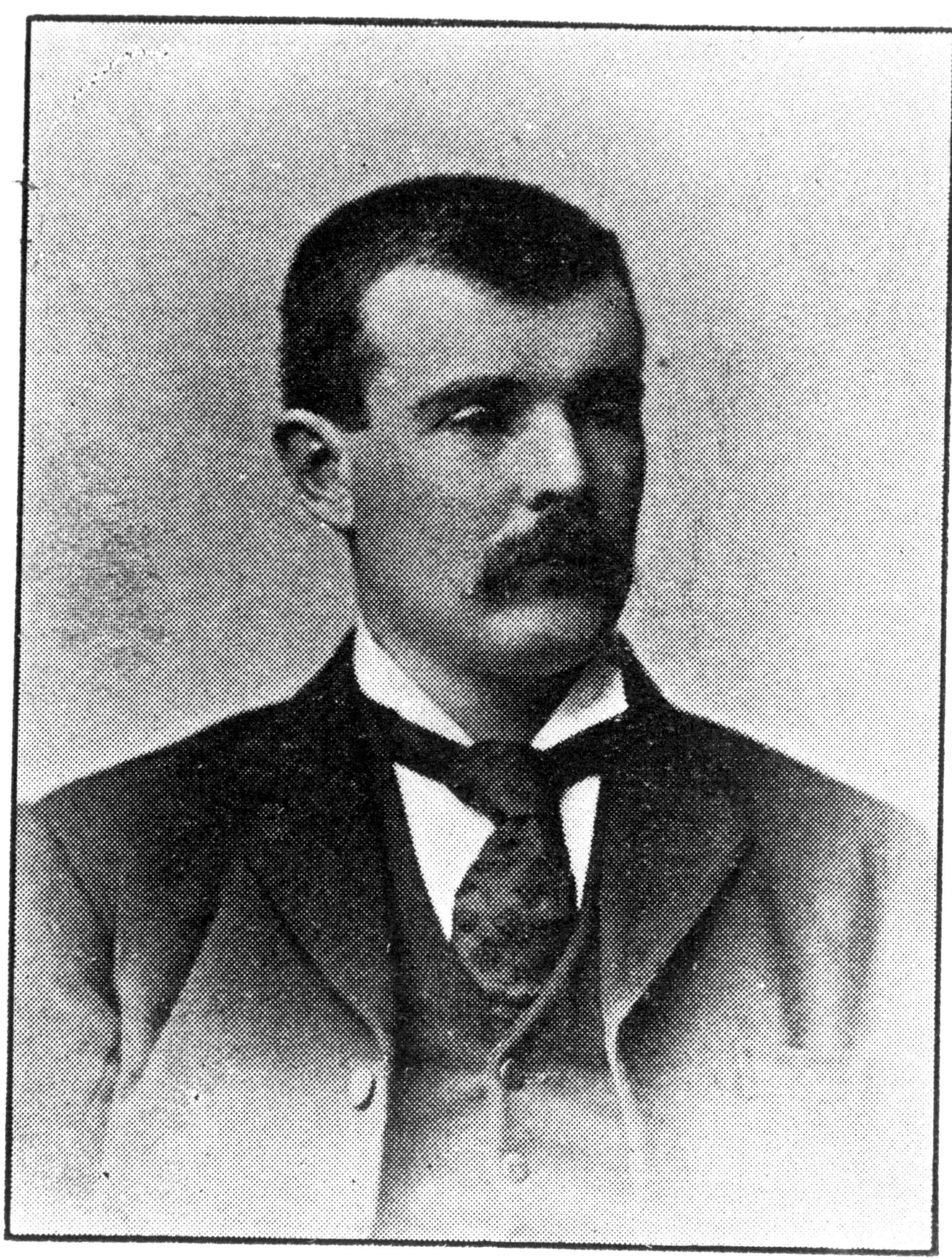

LOUIS KONRAD

LAUNCESTON

Mr. J. T. Wilson. 
of Education, including the prestigious Tasmanian scholarship. In 1887 he began medical studies at the University of Edinburgh and passed with honours. He received magnificent testimonials from teachers, who prophesised "an illustrious future". 74 Wilson practiced in Orkney for two years and in 1893 returned to Launceston where his private practice grew. The Tasmanian Democrat thought Wilson's qualifications were exemplary. ${ }^{75}$ He brought to the position "activity, the vigor of youth and the reputation of having been highly successful as an organiser and administrator". His abilities were displayed in his first half-yearly report presented to the Council in January 1897.76 He had begun an inspection of every house in the town and recorded details of its sanitary condition. Of the 2855 premises he had inspected refuse had accumulated in "many", a number of cesspits had not yet been filled in, and "the general condition of houses in Inveresk, Cataract Hill and Hampden in particular was not, as it should be". Only limited improvements could be made in these suburbs because of "the poverty of many houseowners" and the state of drainage in Inveresk. Wilson inspected many of the animals slaughtered at the Corporation yard and found only "a small amount of disease": he praised Curtin's "zeal and energy". Wilson's report, thought the Daily Telegraph, was "of a character calculated to inspire confidence". 77 The Examiner noted that Wilson had "devoted a fair amount of time to his duties" and would "doubtless give the citizens full value for their money" but, as he was part-time, he could not give Curtin

74. D.T. 8 August 1892 for the testimonials.

75. T.D. 12 June 1896.

76. Ex. 12 January 1897.

77. D.T. 12 January 1897. 
the close supervision he required. ${ }^{78}$ At the end of 1897 Wilson's duties were defined, his annual salary dropping from $£ 150$ to $£ 75.79$ Wilson was now responsible for supervising the work of the Inspector of Nuisances, who carried out daily inspections; preparing an annual report; and investigating the appearance of infectious diseases and advising how to stop their spread. He became therefore merely a nominal head and his annual reports were very short, not displaying that intimate knowledge of sanitary conditions that was a strong point of Bushman's reports.

Under Wilson's guardianship Launceston's death rate only gradually declined but at least his work was free of the controversy that had surrounded Bushman. In 1903 this quiet was dramatically undermined by Launceston's second smallpox epidemic. The impact of the epidemic on Launceston has been analyzed elsewhere. ${ }^{80}$ The Government appointed Dr. J.S.C. Elkington with full powers to halt the epidemic and he did, with characteristic energy. Wilson was embittered by Elkington's appointment, as it detracted from his professional standing, and relations between the two were not good. One clash resulted in Wilson's resignation as Health Officer but, on an appeal from the Local Board, he stayed on. To most Launcestonians Wilson was one of the heroes in the victory over smallpox but Elkington criticised his role during the epidemic., During Elkington's term as Chief Health Officer, in charge of the newly created Department of Public Health, the breach between the two men became patent. Wilson was required to send Elkington a halfyearly report to June 1904 but, despite frequent requests, did not. 81

78. Ex. 14 January 1897.

79. Hobart Gazette, 18 January 1898, p.283 passed by the Loca1 Board of Health 29 November 1897.

80. Roe, op.cit., p.126-45.

81. Ibid.; Ex. 25 October 1904. 
On 7 October Elkington instructed the Local Board of Health to dismiss Wilson, as provided by section 12 of the Public Health Act 1903, for his "neglect or refusal" to send the report. On 28 September Wilson had prepared a report for the Local Board, which had been sent to Elkington, but as it was too brief was asked to present a more "comprehensive" one. Wilson became ill and the report had not been completed. Elkington returned a copy of the first report saying it was "inadequate and incomplete", again demanded Wilson's removal and hinted at other more serious offences. On 17 October the Local Board asked for details of these offences but Elkington declined and argued that the original charge was sufficient justification for Wilson's dismissal. Another, but still slim, report by Wilson was sent to Elkington in which Wilson asserted that he was under the control of the Local Board of Health and no other. authority. Elkington's "innuendoes" had no substance and Wilson maintained that Launceston was "on the whole .... an extremely clean and healthy city". This report, which showed that the scars of 1903 had not healed, only served to strength Elkington's resolve. On 25 October Elkington dismissed Wilson.

The Launceston Local Board appealed to the Government. The Attorney-General, ex-alderman G.C. Gilmore, tried to mediate between the Local Board and Elkington with the aim of reinstating Wilson. 82 In November Elkington informed the Local Board that he was willing to allow Wilson's reinstatement if Wilson would accept that his future as Health Officer was subject to Elkington's approval and that he would carry out any directives laid down by Elkington. 83 If the proud Wilson had privately accepted these reasonable conditions his loss of face would have been negligible and the

82. Ex. 1 November 1904.

83. Ibid 22 November 1904. 
essentially petty dispute would have ended. Instead the Corporation published Elkington's letter in the press, to make it appear that he was being bloody-minded, and its arrogant, blustering tone enhanced Wilson's public support. The Local Board refused to endorse E1kington's conditions. 84 Elkington remained obstinate despite the Premier's intervention. 85

Until a resolution was reached Dr. Lavington Grey Thompson, who had described Elkington's action as "Caesarism", was appointed temporary Health Officer. ${ }^{86}$ Wilson did not relent. He instituted legal proceedings against Elkington for wrongful dismissal and sought $£ 1000$ damages. In April 1905 the case was heard before Justice A.I. Clark and a jury of seven. ${ }^{87}$ During the trial Elkington cited insanitary conditions in Launceston, particularly Youl's lane, as evidence of Wilson's negligence. Wilson's counsel had to prove there was malice in Elkington's actions but, in his summing up, Clark held that malice was not present and that Elkington was merely discharging the duties of Chief Health officer. 88 Clark stressed the importance of a centralized Health Department free from "all local influences". The jury's verdict was in favour of Elkington. Some aldermen refused to accept the verdict and sought the opinion of Henry Bourne Higgins, who questioned the legality of Wilson's dismissal: an opinion of Alfred Green, a leading Launceston lawyer, supported Clark. ${ }^{89}$ Despite

84. Ibid 6 December 1904.

85. Roe, op. cit., p.144.

86. Ex. 1, 24 December 1904.

87. Ibid 4, 5, 6 April 1905.

88. Ibid 7 April 1905.

89. Ibid 16, 23 May 1905. 
attempts by Wilson's friends, particularly Peter McCrackan, to retain his services, the majority of aldermen accepted the Court's decision. 90

The position of Health Officer was advertised. From the 10 applicants L.G. Thompson was chosen. 91 Thompson, a friend of Wilson, had a similar career and interests. He was born in Launceston in 1855 and educated at Launceston Church Grammar School. 92 After gaining his medical degree from Edinburgh University, he worked in England and Queensland. He was Surgeon-Superintendent of the Launceston General Hospital from 1881 to 1889 before commencing a private practice. Like Wilson he was well-known for his sporting interests. He also had extensive business interests. He was a friend of the poor of Launceston and often gave help "to many sick, suffering or indigent folk". ${ }^{93}$ Thompson remained Health Officer until his death in 1923. He was an ardent municipalist. In November 1904, when addressing a banquet of the St. Andrews Club, he eulogised the work of the Glasgow Corporation. 94 He referred to what "might be called Socialism, but which he nevertheless advocated most strongly and that was the inauguration [by the Corporation] of a tramway system for Launceston". He thought it preferable that the Corporation invest in land and use the profits to the advantage of the city rather than "the landbroker and land speculator".

90. Wilson died of an "apoplectic seizure" in July 1906 Ibid 25 July 1906.

91. Ibid 23 May, 20 June 1905.

92. C. Craig, Launceston General Hospital: The First Hundred Years 1863-1963, (Launceston, 1963), p.30.

93. D.T. 25 October 1923.

94. Ex. 1 December 1904. 


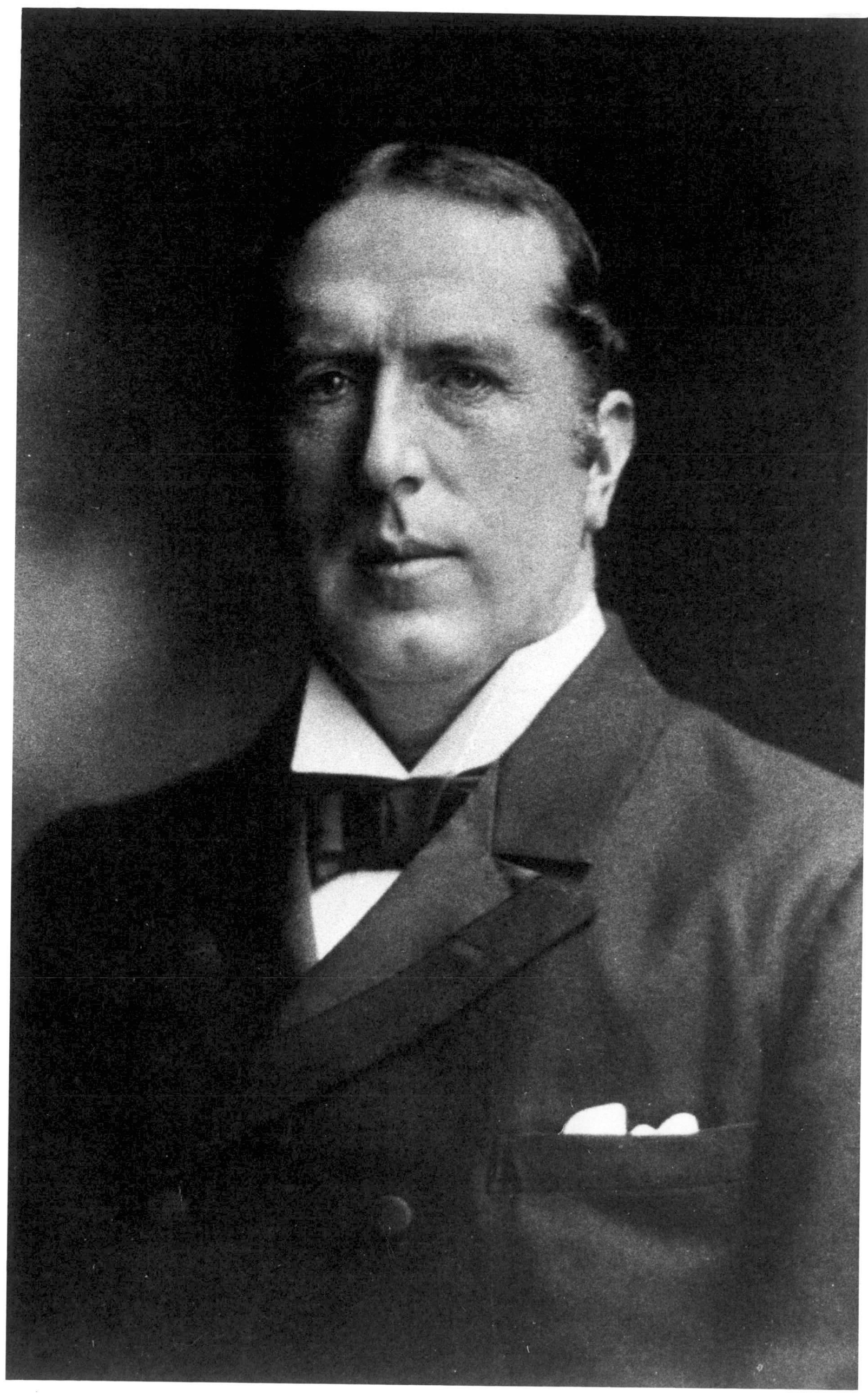

DR. L.G. THOMPSON 
As early as 1884, when he gave a public lecture, Thompson exhibited a keen and informed interest in public health. 95 He believed that a Health Officer should be "largely endowed with moral courage", have "strong perceptive faculties", and "must exhibit courtesy, tact and resolution when bringing his fellow citizens to book for an offence against the public health", all qualities that Thompson had in good measure. He was particularly concerned with lowering the infant mortality rate and assisted all philanthropic efforts to protect the health of children. Thompson paid greater attention to hairdressers, milk sellers and the condition of housing. His suggestions for sanitary improvements were always carefully formulated, practical and embraced all aspects of a problem. His reports often contained a touch of humour. Unpopular recommendations weré not avoided and legislation in operation in other parts of the world was cited as a precedent for change. Elkington noted with approval the "considerable activity" displayed by Thompson after he was appointed Health Officer. 96 Relations between the two were co-operative, if not friendly, and they respected each others opinions. In 1907 Elkington warned of the danger caused to Launceston's water supply by the increasing residential population near the catchment area "and of cesspools and defective closets in close proximity to tributary streams. No means of filtration before distribution is provided and the storage capacity is inadequate to secure reasonable purification of the supply". 97 Thompson did not feel slighted and investıgated the danger. 98

95. Ibid 26 April 1884.

96. T.P.P. 1905/6.

97. T.P.P. $1908 / 41$.

98. Ex. 11 February 1908. 
Thompson differed with Elkington by finding that the water could be used "without any deleterious results" but agreed that, as population increased, storage facilities would have to be expanded and filtration was desirable: he also informed residents likely to pollute the streams of the provisions of the Rivers Pollution Prevention Act. At first aldermen denied that the vaunted water supply was at risk but in December 1908, persuaded by the reports of Elkington and Thompson, agreed to measures to minimise the chances of pollution and that filter beds would be necessary in the future. 99 Thus the co-operation of the two health officials was fruitful. 100

The threat to the health of Launceston posed by the inadequate sanitary regulation of surrounding towns had long been recognised. In 1907 this threat was diminished when the towns of Invermay and Trevallyn were amalgamated with Launceston but no addition was made to the staff of the Health department for inspection purposes. In 1901 Murnane became City Inspector in addition to being an Inspector under the Public Health Act. ${ }^{101}$. Alderman Sadler warned that "too much was being expected of the inspector and the health of the city might be injuriously affected". Further strains were placed on Murnane in subsequent years: in August 1904 he was appointed Inspector of Common Lodging Houses, in May 1911 he became Food and Drugs Inspector and in July 1911 Factories Inspector. ${ }^{102}$ In July 1911 Thompson asked for the appointment of "an additional

99. Ibid 2, 15 December 1908.

100. In an interview with the Mercury Elkington stressed that he was not reflecting on Thompson's abilities and suggestions that he was making "a personal attack" on Thompson aimed to divert attention from the real issues M. 2 December 1908.

101. Ex. 5 June 1901.

102. Hobart Gazette, 23 August 1904, p.76; Tasmanian Government Gazette, 9 May 1911, p.1702 and 18 July 1911, p.2091. 
inspector without delay" but with no success: in his annual report he reiterated the request. ${ }^{103}$ By 1911 Launceston, with a population of over 21,000 had 67 miles of streets and 3000 houses. According to Thompson "In any well-administered city it is reckoned that one inspector is required for 10,000 inhabitants" and without another inspector for Launceston it was "physically impossible to do justice to the situation". He continued:

The department removes house and shop refuse and other matter; it attends to drainage, and serves notices for repairs and reconstruction, and manages all the consultations with owners and agents in respect to all businesses, nearly all of which work is carried out by other departments in other cities. The new legislation imposes extra duties on the officers, which must involve night work .... The department requires an additional inspector - one who has obtained. his credentials by actually passing examinations, and who can give particular attention to the drainage and plumbing throughout the city.

Thus it was recognised that sanitary inspectors required special training. During 1912 the appointment of an Inspector of Factories for the north, attached to the Central Board of Health, to some extent relieved the burden for Murnane. Still, Murnane remained "a sort of Jack of all trades, with enough duties piled on his shoulders as would keep half a dozen experts going, if effectively performed ...." 104 Financial considerations worked 
against the appointment of an extra inspector, as was the case with many public health matters. Another example was in the treatment of infectious diseases. The Public Health Amendment Act 1910 made each local authority responsible for the treatment of people with infectious diseases, within its jurisdiction, who were ordered into hospital by a doctor, the Chief Health Officer or local Health Officer: the cost of treatment could be recouped from the person receiving it or his family. In April 1914 the Launceston Corporation reached an agreement with the Launceston General hospital, whereby the Hospital would treat infectious diseases on payment of five shillings per patient per diem. ${ }^{105}$ This arrangement, wrote the Mayor, who was a member of the Hospital Board, saved the Corporation the expense "of erecting and maintaining a special hospital" for infectious diseases, but it was not cheap. ${ }^{106}$ It was found that "in the majority of cases" it was "impossible to recover the sums due without inflicting hardship". The Mayor estimated that the arrangement would cost "close on $\$ 300$ per annum". Part of the reason why the Launceston Corporation did not manage an infectious diseases hospital and the Hobart Corporation did was that in Hobart the General Hospital refused to accept infectious diseases cases; the Launceston General Hospital had no such objection. Tuberculosis or consumption, wrote the Daily Telegraph in 1904, "destroys more human lives .... than all .... [infectious diseases] put together" but "has .... been marked by much apathy and neglect". 107

105. Ibid 21 April 1914; D.T. 28 April 1914.

106. Ex'. 8 December 1914. In 1898 infectious diseases wards were built at the Ǵeneral Hospital, mainly with voluntary subscriptions Ex. 23 December 1898. According to Craig, op.cit., p.131 these wards were demolished in 1912 and an Infectious Diseases Hospital built in 1920.

107. D.T. 18 August 1904. 
By 1909 accommodation for consumptive patients at the General

Hospital, according to the Surgeon-Superintendent Dr. John Ramsay, was "inadequate" and a consumptive sanatorium, as was opened at New Town in 1906, was urgently needed. ${ }^{108}$ The Launceston Corporation appears not to have considered building a sanatorium, again probab1y because of the cost. 109

In his annual report of 1914 Thompson thought in the past decade "The health of the residents has been good .... and must prove satisfactory to the Local Authority". 110 Although fluctuations in the estimates of population statistics makes complete accuracy difficult, let us consider how healthy Launceston had become by looking at the general death rate. From 1888 to 1892 the average general death rate for the city was about 22.22 per 1000 and for the urban district, which included surrounding suburbs, about 20.27 per 1000. (Table 8) From 1910 to 1914 the average general death rate for the city was about 13.43 per 1000 and for the urban district about 13.44 per 1000 . Thus the general death rate fell by about a third. An even more striking success was the infant mortality decline. From 1888 to 1892 the average death rate of infants under one year was 149 per 1000 births. ${ }^{111}$ (Table 9) From 1910 to 1914, a period when, apart from generally improved sanitary conditions, registration of boarded-out infants was much tighter, it was about

108. Ex. 1 June 1909.

109. Friendly Societies in Northern Tasmania considered building a sanatorium in 1910 but decided against it. Ex. 27 August, 24 October 1910; D.T. 16 January 1911. The only consumptive sanatorium in the north was established at Campbell Town in about 1906 by Dr. W.H. Tofft, D.T. 4 May 1907.

110. Ex. 13 January 1915.

111. The source from which these statistics were derived does not make clear if they refer to the city or the urban district but it was probably the latter. 
TABLE 8 : LAUNCESTON'S DEATH RATE PER 1000

\begin{tabular}{|c|c|c|c|c|}
\hline Year & City & Suburbs & District & \\
\hline 1886 & - & - & 23.79 & \\
\hline 1887 & - & - & 24.87 & \\
\hline 1888 & 23.20 & 12.39 & 20.61 & \\
\hline 1889 & 25.61 & 14.73 & 23.00 & \\
\hline 1890 & 21.25 & 12.56 & 19.38 & \\
\hline 1891 & 20.71 & 13.18 & 19.26 & \\
\hline 1892 & 20.35 & 13.78 & 19.09 & \\
\hline 1893 & 20.12 & 12.07 & 18.57 & \\
\hline 1894 & 17.49 & 11.68 & 16.37 & \\
\hline 1895 & 14.09 & 9.43 & 13.19 & \\
\hline 1896 & 16.37 & 9.17 & 14.98 & \\
\hline 1897 & 13.02 & 9.91 & 12.42 & \\
\hline 1898 & 18.02 & 10.41 & 16.55 & \\
\hline 1899 & 13.93 & 8.53 & 12.89 & - \\
\hline 1900 & 15.31 & 10.97 & 14.66 & \\
\hline 1901 & 14.12 & 12.19 & 13.83 & \\
\hline 1902 & 17.55 & 12.28 & 16.74 & \\
\hline 1903 & 16.10 & 19.28 & 16.59 & .. \\
\hline 1904 & 13.94 & 12.86 & 13.77 & \\
\hline 1905 & 14.09 & 9.54 & 13.38 & \\
\hline 1906 & 15.75 & 6.22 & 14.25 & \\
\hline 1907 & 11.75 & 23.19 & 12.63 & \\
\hline 1908 & 12.41 & 21.08 & 13.09 & \\
\hline 1909 & 11.66 & 20.77 & 12.36 & \\
\hline 1910 & 1.157 & 38.42 & 13.65 & \\
\hline 1911 & 13.52 & 13.87 & 13.55 & \\
\hline 1912 & 14.10 & 10.66 & 13.71 & \\
\hline 1913 & 14.61 & 7.71 & 13.79 & \\
\hline 1914 & 13.36 & 6.55 & 12.51 & \\
\hline
\end{tabular}

Source: Statistics of Tasmania. 
TABLE 9 : LAUNCESTON'S INFANT MORTALITY RATE

\begin{tabular}{|c|c|}
\hline Year & Deaths Under 1 per 1000 Births \\
\hline 1885 & 180 \\
\hline 1886 & 177 \\
\hline 1887 & 136 \\
\hline 1888 & 130 \\
\hline 1889 & 173 \\
\hline 1890 & 145 \\
\hline 1891 & 129 \\
\hline 1892 & 170 \\
\hline 1893 & 149 \\
\hline 1894 & 121 \\
\hline 1895 & 102 \\
\hline 1896 & 158 \\
\hline 1897 & 114 \\
\hline 1898 & 207 \\
\hline 1899 & 136 \\
\hline 1900 & 104 \\
\hline 1901 & 104 \\
\hline 1902 & 124 \\
\hline 1903 & 155 \\
\hline 1904 & 95 \\
\hline 1905 & 109 \\
\hline 1906 & 113 \\
\hline 1907 & 100 \\
\hline 1908 & 89 \\
\hline 1909 & 108 \\
\hline 1910 & 136.42 \\
\hline 1911 & 100 \\
\hline 1912 & 74.66 \\
\hline 1913 & 77.37 \\
\hline 1914 & 61.50 \\
\hline
\end{tabular}

Source: Statistics of Tasmania, 1914, p.129. 
89.99,per 1000 births. ${ }^{112}$ Reasons for the decline of infectious diseases, particularly typhoid, will be examined in the next chapter. Although the factors affecting the incidence of disease are admittedly complex, it is fair to claim that the attention given to sanitation by the Launceston Corporation was a major contributing factor in lowering the death rate.

112. The failure of local authorities to register women who took in children for payment resulted in the Infant Life Protection Act 1907, which transferred this duty to the police. 


\section{CHAPTER FOUR}

\section{WASTES}

The nineteenth century city faced numerous problems affecting the public health. These problems differed in extent between cities depending upon factors such as the size of the population, the development of industry, the geographical and topographical characteristics and the level of poverty. ${ }^{1}$ Launceston had many advantages, being a relatively prosperous city with a small population inhabiting a large area of territory but it was not immune from threats to health. For most cities the most obvious cause of disease was an impure environment. ${ }^{2}$ Whether the miasma or germ theories of disease causation were in vogue a central aim was to get rid of filth in the form of decaying wastes generated by humans, particularly refuse and excrement. This chapter focuses on how the Launceston Corporation cleaned up the city.

The Removal of Refuse

The accumulation of garbage and other kinds of refuse was the most common form of pollution that beset cities in the nineteenth century. ${ }^{3}$ The amount of refuse generated by Launceston's small population was minute compared with cities like New York or Sydney but the widespread accumulation of refuse had prompted the Launceston Corporation to conduct its enquiry into the sanitary

1. G. Rosen, "Social Variables and Health in an Urban Environment: The Case of the Victorian City", Clio Medica, v.8, No. 1, 1973, p.1-17.

2. For general comments see A.S. Wohl, Endangered Lives: Public Health in Victorian Britain, (London, 1983), Chapter 4 and M.V. Melosi (ed.), Pollutlon and Reform in American Cities 1870-1930, (Austin, 1980).

3. American historians have pioneered the study of urban refuse problems. Pre-eminent is M.V. Melosi, Garbage in the Cities: Refuse Reform and the Environment 1880-1980, (Texas, 1981); see also J.W. Leavitt, "The Wasteland: Garbage and Sanitary Reform in the Nineteenth Century American City", Journal of the History of Medicine and Allied Sciences, v.35, 1980 , p.431-52. 
state of the town in 1883. By 1886 removal of refuse was confined to "the centre of the town [where] dust boxes, provided by the occupants of the houses, are daily emptied". 4 In his half yearly report of 1886 Bushman argued for the extension of refuse removal to the rest of the city. ${ }^{5}$ He believed scavenging was "the foundation of all sanitary science"; sewers, drains and a pure water supply were "all secondary considerations if scavenging be neglected". Refuse should be removed "from the premises of every individual, and every manufactory, and every place, at the cost of the general body, and the cost should be paid out of the general rate .... If you leave it to a private individual it is never done and becomes the source of serious evil". Also it was more "economical" for the Corporation to remove refuse than for individual ratepayers.

Refuse removal practices of residents underlined the need for municipal control. Ratepayers often complained to the Corporation and in the press that refuse was dumped indiscriminately on vacant land or in streets and they were worried that disease would be fostered. 6 A proper system of refuse removal was needed, wrote Bushman, because then rubbish would "only be deposited in such places as ordered, instead of as at present on outlying streets and vacant allotments, a practice which not only affects the present residents in the vicinity, but in the future will become a source of disease the extent of which no-one can form an estimate". 7 In April 1888, when typhoid was very prevalent, aldermen, influenced by the Mayor B.P. Farrelly, who had a special interest in.

4. T.P.P. $1886 / 139$.

5. Ex. 2 November 1886.

6. Ibid 18 May 1886 for a memorial of ratepayers.

7. Ibid 20 March 1888. 
sanitation, and Henry Button, decided to remove refuse from every house. 8 By taking $2 \mathrm{~d}$. from the general rate and adding it to the new sanitary rate, the new service did not result in an increase in rates. Street sweepings and ashes were deposited on a piece of ground adjoining the Launceston Cricket Ground: the rest was burnt. 9

As more residents in various parts of Launceston used the service the amount of refuse collected increased so much that towards the end of 1889 another cart was needed to ensure that refuse bins were not left full for too long. 10 The Daily Telegraph underscored the need for an extra cart by claiming that

Complaints loud and deep came from all parts of the city of the utter want of system obtaining in connection with removing rubbish from the premises of citizens .... In some cases the rubbish has not been removed for a month, the accumulations thus becoming a putrifying(sic) mass, breeding corruption and creating disease. 11

By December 188940 tons of garbage was removed week1y, which was, said Mayor David Scott, "an inestimable boon to the poorer class". 12 By 1895 one cart was employed daily to remove refuse and on three days of each week a second cart provided 2250 houses with a weekly serivce. ${ }^{13}$ About 60 tons of garbage was collected each week.' A bell warned citizens that the refuse cart was

8. Ibid 6, 17 April 1888.

9. Ibid 2, 16 October 1888:

10. Ibid 6 August 1889.

11. D.T. 7 August 1889 .

12. Ex. 11 December 1889.

13. Ibid 3 December 1895. 
approaching and they were required to place receptacles "in rightsof-way or yards, and not in streets, except where unavoidable". 14 Citizens were requested "that in the event of negligence on the part of the employee, complaint be made to the Officer of Health". If the success of the refuse removal system was measured by the number of complaints, then it was very successful because complaints were few and most residents enjoyed the benefits of regular removal. Bubonic plague was associated with filth and in 1900 the Launceston Corporation quickly responded to the appearance of bubonic plague on the mainland. ${ }^{15}$ Circulars listing precautions to take, such as cleaning yards and disinfecting water closets, were disseminated throughout the city. ${ }^{16}$ The task was not as large as it was in Hobart, wrote the Examiner, because of "the cleanliness for which.Launceston has ever been proverbial and the general excellence of its sanitary arrangements". 17 Rubbish was removed from "many of the less frequented thoroughfares and especially rights-of-way. Extra men and carts have been put on to ensure the prompt removal of all that was out of place and private premises have been carefully inspected, and a thorough cleansing of back yards etc. insisted üpon. The resultant rubbish has been carted away and buried". Disinfectant was poured down "every sewer and drain in the city".

14. Hobart Gazette, 18 January 1898, p.284.

15. For accounts of the plague in Australia see J.H.L. Cumpston and F. McCallum, The History of Plague in Australia 1900-25, (Melbourne, 1926) and B. Rosen, "Australia's Contribution to the Conquest of Plague", Roval Australian Historical Society Journal, v.63, 1977, p.60-71.

16. Ex. 16, 17, 29 March 1900.

17. Ibid 2 May 1900. 
As much vigour was put into rat extermination, as rats were the major carriers of the plague, but success was harder to achieve. At first, in co-operation with the Marine Board, poison was spread around the wharf area but few dead rats were found. Then a reward of $2 \mathrm{~s}$. per dozen rats caught was offered "but even this has failed to bring about any noticeable increase in the daily 'catch"'. A Rat Committee was formed with members of the Central Board of Health, the Launceston Corporation and the Marine Board: $6 \mathrm{~d}$. per rat was offered. 18 Rat extermination continued with some success from 1900 to 1914 as an annual precaution against bubonic plague. In the event of a bubonic plague outbreak bacteriological analysis of cases was necessary to distinguish real from other cases. Bacteriological apparatus had been purchased by the Launceston General Hospital in 1896 but not used. In March 1900 Dr. Hogg wrote to the Examiner and the Daily Telegraph that the major gap in the precautions taken against the plague was "the lack of means for proper bacteriological examination of suspicious cases". 19 He called for Government assistance to . enable the General Hospital to set up a baterıological laboratory and in 1901 this was done. 20

Burning or burying the rubbish that had been collected were the most common methods of disposal used by cities. ${ }^{21}$ Refuse destructors were considered by most sanitarians to be a safer alternative. In 1901 Launceston's City Engineer Charles St. John David told the Royal Commission on the Municipal Government of Hobart and Suburbs that the Launceston Corporation "had the question of

18. Ibid 15, 17 May 1900.

19. Ibid 15 March 1900; D.T. 15 March 1900.

20. C. Craig, Launceston General Hospital: First Hundred Years 1863-1963, (Launceston, 1963), p.59.

21. Melosi, Garbage in the Cities, op.cit., Chapter 6. 
procuring destructors before us; but the cartage is so short out to [ the tip at Invermay Park] .... that it is not worthwhile". 22 "Of course", David continued, "I have been studying the subject, and keep reading it up". He thought the purchase of a destructor was "just a matter of pounds, shillings and pence, .... Where the cost of getting rid of the stuff by cartage is so great that it is cheaper to get destructors and burn it near at hand, destructors are good". Thus David regarded the purchase of a destructor as an economic and not a health consideration. The Examiner did not share this view. In April 1907 it reproached the Council for allowing rubbish to be dumped "into festering, evil-smelling heaps", which threatened health and was not "worthy of a corporation claiming to be up-to-date". 23 This was the typical kind of complaint levelled at tips, particularly disliked because they attracted flies, but the Launceston Corporation rarely discussed the purchase of a destructor. On the whole the Launceston Corporation was very successful in keeping the city clean and thus keeping the incidence of infectious diseases low.

\section{Nightsoil}

a) The Pan System of Nightsoil Removal

In Hobart, as we shall see, the mismanagement of the pan system of nightsoil removal caused numerous headaches for aldermen and contributed to the low esteem in which the Corporation was held. In Launceston the existence of a sewerage scheme meant that water closets were more widely used than in Hobart and the use of the pan system was limited: cesspits and waterwashed pits were also in use. As the sewerage scheme was extended to embrace

22. T.P.P. $1901 / 5$, p.157.

23. Ex. 16 April 1907. 
all of Launceston, pans, cesspits and waterwashed pits would be phased out. Pans were removed by contract for the Corporation. 24 Nightsoil was deposited at the Sandhills on Hobart Road, in the district of the Breadalbane Road Trust and on land near the Racecourse, in Invermay and buried in three foot trenches.

The pan system was not completely free of problems. In March 1886 Henry Button described the tender system as "an utter failure" and wanted the Corporation staff to remove pans. ${ }^{25} \mathrm{He}$ favoured the duplicate pan system so that dirty pans could be replaced with clean ones. This would remove "all offensiveness and the disgust that the present mode caused". Waterwashed pits were even more offensive and dangerous to health. In his half yearly report of 1886 Bushman noted that fever was "frequent" and of "a most fatal and virulent nature" in localities such as Lower George, Cimitiere, Cameron and Tamar Streets, where waterwashed pits were used. $^{26}$ Waterwashed pits, Bushman warned, were "a standing menace .... They pollute not only the air and soil of the premises on which they are placed, but for a large area in their vicinity, and no doubt have in the past been the cause of more disease and death than any other existing evil". When first appointed Bushman had begun to abolish waterwashed pits as far as existing legislation allowed. The Public Health Act 1885 gave him full power and he hoped by 1888 that "there will not be one [waterwashed pit] remaining to disgrace the town". No-one was exempted by Bushman. In April 1888, for example, Alderman W.F. Wathen was forced to rid his premises of a waterwashed pit when, after an appeal, Bushman was supported by other aldermen. 27

24. T.P.P. $1886 / 136$.

25. Ex. 9 March 1886.

26. Ibid 2 November 1886.

27. Ibid 1 May 1888. 
By December 1888 much had been achieved. The Corporation had taken over the removal of pans and emptied cesspits and waterwashed pits: 6797 tons of nightsoil had been collected. ${ }^{28}$ The number of cesspits had been reduced to 165 and waterwashed pits to 54. (Table 10)

TABLE 10 : METHODS OF DEALING WITH NIGHTSOIL IN LAUNCESTON

\begin{tabular}{|l|r|r|}
\hline & 1884 & 1888 \\
\hline Cesspits & 1601 & 165 \\
Waterwashed pits & 543 & 54 \\
Pail Boxes & 436 & 1110 \\
Water closets & 458 & 1907 \\
\hline
\end{tabular}

Source: Ex. 16 April 1889.

Houses within 100 feet of a sewer were compelled by law to connect with the sewerage scheme. ${ }^{29}$ By June 1895 cesspits and waterwashed pits were virtually non-existent: 3180 water closets were in use, supplemented by 614 pails. ${ }^{30}$ Bushman had succeeded in abolishing cesspits and waterwashed pits and his successor John Wilson aimed to eradicate the night cart, wanting sewers to be rapidly extended to outlying suburbs. 31 The cost of connecting a house to a sewer was from $£ 7$ to $£ 8$ and, to assist those who found difficulty in paying this amount, the Corporation "in a great many instances allow [ed] payment by instalments". ${ }^{32}$ In 1908 the Launceston Corporation took over the pan system for Trevallyn and for Invermay, until it was sewered in 1910. Thus alternatives to water closets were only used as temporary expedients because

28. Ibid 16 April 1889.

29. Public Health Act 1887 clause 18.

30. Ex. 3 December 1895.

31. Ibid 21 February 1899.

32. T.P.P. 1901/5, p.154. 
they were regarded as insufficient safeguards against disease, although under municipal control their threat to health was minimised. Water closets, however, were not without their critics. b) Launceston's Sewerage Scheme

Of all the public health measures that were designed to prevent disease in the nineteenth century, none received as much publicity by sanitarians as sewerage systems. There appeared to be a direct connection between the lowering of infectious diseases, in particular typhoid, and the construction of sewers: water closets had fewer risks to health, were more efficient, less labour intensive and, in the long term, less expensive than other methods of dealing with human excreta. 33 Despite the advantages of a sewerage scheme, it was not always adopted without opposition, as we will see in the case of Hobart. One argument was that Launceston's sewerage system, started to be built in 1860, had not prevented the appearance of typhoid. This argument failed to acknowledge that only a relatively small number of residents in Launceston owned water closets by 1885 , as shown by Table 10. The argument also denied the contribution of other factors to the origin and spread of typhoid but it was true that the sewerage system in Launceston was not an unmixed blessing.

33. For Melbourne's sewerage scheme see W.A. Sinclair, "Economic Growth and We11-being: Melbourne 1870-1914", Economic Record, v.51, 1975, p.153-73, who stresses the health and economic considerations involved in its adoption. Some of Sinclair's calculations have been contested by D.T. Merrett, "Economic Growth and Wel1-being: Melbourne 1870-1914, A Comment", Economic Record, v.53, 1977, p.262-8, and for his rejoinder see W.A. Sinclair, "Economic Growth and Well-being: A Comment on a Comment", Economic Record, v.53, 1977, p.269-71. For the advantages of water closets see J.A. Tarr, J. McCurley and T.F. Yosie, "The Development and Impact of Urban Wastewater Technology: Changing Concepts of Water Quality Control 1850-1930" in Melosi, (ed.), Pollution and Reform, op.cit., p. 59-82. 
In his 1886 report on the sanitary condition of Launceston Alfred Mault, Engineering Inspector to the Central Board of Health and Tasmania's pre-eminent sanitarian, described the main features of Launceston's sewerage scheme. ${ }^{34}$ Outfall drains were built in Margaret Street, Charles Street, St. John Street, George Street and Tamar Street. The Margaret Street sewer was the largest outfall drain and took land drainage, house sewage and street drainage. The invert of the outlet of the Margaret Street sewer is below high-water level, and is not flapped; the tides consequently ordinarily flow two or three hundred yards up the sewer, and when the rivers are in flood sometimes inundate the lowlying part of the town in the neighbourhood of the crossings of Bathurst Street with York and Elizabeth Streets.

Much of this sewer required "repair or reconstruction". About $18 \frac{1}{2}$ miles of sewers had been built at a cost of approximately ¿40,000 but "to properly drain the whole urban area, including much that is at present hardly built upon, sixteen miles more of branch sewers will have to be constructed". This would cost about $£ 15,000$. All sewage was discharged into the River Tamar or into the North Esk "within half a mile of its junction with the Tamar". The tidal flow of the Tamar meant that "at low water about 140 acres of mud banks are exposed to the action of the sun and air within the limits of the town". The tide deposited much of the sewage on the mud-banks "and the effluvia raised from it in its periodical exposure to sun and air are carried over the town by the prevailing winds". The section of Launceston most affected

34. T.P.P. 1886/139. For Mau1t see A.D.B., v.5, p.229-30. 
by "this nuisance" was the "low-1ying marshy" section, which was "already insalubrious".

Mault recommended the removal of this nuisance, which would become worse as the population grew. The existing outfalls made it "impracticable .... to establish sewage purification and pumping works". Mault suggested that sewage be conveyed "by gravitation to some place where it could be purified or at least clarified by precipitation, and discharged into the river twice a day when the tide permitted". For the town Mault proposed marsh land on the North Esk, opposite the Soapworks, and for Inveresk swamp land at the end of Forster and River Streets. The cost of such a scheme, including intercepting sewers, would be $\$ 26,000$ and the annual cost, including lime for precipitation, about $£ 3,700$. Mault did not favour this scheme because "The necessity of having two sets of large tanks, two establishments and two outfalls, one at each side of the river, is very costly and otherwise undesirable". Also whenever the river was in flood "the tidal discharge would be interfered with and much inconvenience would be suffered and great damage might be done"'. Other solutions entailed "the raising of the sewage by mechanical means" and using one outfall at Inveresk, with clarifying tanks. Mault described the operation of Shone's pneumatic ejectors, which were used at Eastbourne and other towns in England. If they were used the cost, including intercepting sewers, would be about $£ 17,000$ and about $£ 2,490$ annual1y.

Inveresk, as we know, was largely undrained and Mault addressed himself to the problems associated with this area. 65 acres of a possible 378 acres had been used for streets and buildings by 1886. Overcrowding was high and in one 10 acre block there were 47 people to the acre, while in the urban part of Launceston the 
average was 11.4 per acre. Thus, wrote Mault, "in Launceston, as elsewhere, where the houses are the smallest, and where the means of ventilation, drainage, and other conditions of living are the worst, there the population is the most crowded". At Inveresk the need to dry the subsoil was "urgent". The Town Surveyor Edward Fitzherbert estimated that it would cost $£ 38,100$ "to properly make and sewer the streets, and drain the land" and he could not guarantee that "the healthiness of the Swamp would be increased in any very great measure". Fitzherbert thought that the Corporation should seek the power to repurchase the Swamp, other than the 65 acres already built on, and "prevent any further occupation of it for human habitation". Mault agreed and thought the Swamp an ideal site to treat sewage before it was discharged into the Tamar. The Glebe Swamp also needed attention. 35 To "increase the salubrity of the town" Inveresk and the Glebe Swamp had to be drained with the help of ejectors. This was urgent because patients from the low lying swamp areas, according to a return from the Launceston General Hospital, made up the majority of fever cases treated in the Hospital.

The response to Mault's report was not encouraging. The Daily Telegraph, at this time a proponent of running sewage into the Tamar, disagreed that the effluvia from the exposed mud-banks was "offensive": the air at the mud-banks and sewer outlets was "as sweet as in any parts of the town". 36 Mault's suggestions were too expensive and for the most part unnecessary. The Examiner thought the report brought no new facts to light and only described improvements that Bushman and Fitzherbert had already proposed over the last 3 years. ${ }^{37}$ Aldermen had

35. For a description of the Glebe Swamp see also D.T. 3 March 1886. 36. Ibid 29 October 1886.

37. Ex. 26 October 1886. 
done as much as they could with limited revenue. This was fair comment, but Mault had highlighted the major problems of Launceston's sewerage scheme and they would have to be tackled in the future. As Mault was writing his report one of these problems, the disposal of sewage into the Tamar, came under attack.

In August 1886 the Corporation decided to make the water closet system uniform throughout the town. ${ }^{38}$ However the powers under the Public Health Act were inadequate and the Attorney-General would be asked to make the necessary amendments to the law. Henry Button protested against this decision. ${ }^{39}$ He reminded aldermen that on three occasions, in 1859, 1874 and 1877, resolutions had been passed for the abolition of water closets and in favour of the Rochdale removable pan system. 40 Althought Button's protest was recorded, the report was adopted but Button was not deterred. In September Button, with Aldermen S.C. Sadler and John Ellis, listed 11 objections to the water closet system. ${ }^{41}$ The central objection was the pollution of the Tamar. They claimed that medical men were "unanimous in condemning the discharge of excrement into the river", and that "a large proportion of the inhabitants of Launceston" thought the use of water closets to be "both repulsive in its nature and pernicious in its consequences", with excrement settling on the mud flats close to the city. The widespread use of water closets " will be fraught with great and ever-increasing

38. Ibid 24 August 1886.

39. Ibid 31 August 1886.

40. For the Rochdale system see T.P.P. 1886/47, p. 10.

41. Ex. 7 September 1886. The objections were similar to those used in England against the pollution of the Thames see T.F. Glick, "Science, Technology and the Urban Environment: The Great Stink of 1858" in L. Bilsky (Ed.), Historical Ecology: Essays on Environment and Social Change, (New York, 1980), p.122-139. 
peril to the health of the community" and would be a "great expense" for the burgesses: the expense would be increased "when the disastrous character of the [water carriage] system had been fully realised and the public voice shall demand its abandonment". It was also a waste to discharge excreta into the harbour because it had "high fertilising qualities" and could be used, as it was by farmers in America, as manure. ${ }^{42}$ The Rochdale system was cheap and working well in Birmingham. Finally if infectious diseases broke out in the city, "the indiscriminate mingling and discharge into the river of faecal matter would be calculated to disperse the specific poison germs in all directions". When the Rochdale system was used an outbreak of infectious disease could be traced to a particular house and "the excreta from it could be collected separately and disinfected or destroyed".

The opinion of the majority of aldermen was not altered by these objections and the public seemed oblivious to the alleged danger. Button and his supporters were, however, accurate in stating that some doctor's were against discharging sewage into the Tamar. In March 1887 Doctors W.G. Maddox, C.J. Pike, L.G. Thompson, J.M. Pardey, H.C. Hallowes and W.R. Stewart wrote to the Examiner that they had consistently opposed the extension of water closets and their warnings had been borne out because, since the number of water closets draining into the river had grown, there had been "a steady increase in the number of cases of diphtheria, typhoid and other allied fevers and disorders". 43 In the past, they claimed, these diseases "were limited in number and lasted only

42. This was also done in England see N. Goddard, "19th-Century Recycling: The Victorians and the Agricultural Utilisation of Sewage", History Today, v.31, 1981, p.32-6.

43. Ex. 23 March 1887. 
during the two or three hottest months; but, latterly, during the major part of the year, the town has not been free from some or other of these diseases". The doctors firmly believed the diseases were "caused by the river pollution" and wanted to make their protest public. The expert view of the doctors commanded respect and Mayor Carter asked Bushman to investigate the connection between water closets and disease. On 28 March Bushman reported that in recent years Doctors Murphy and Maddox had commented on the decrease in fever cases, particularly in areas where waterwashed pits were replaced by water closets. 44 Thus he concluded that water closets were a protection against, and not a cause of, disease.

On 4 April the doctors' claims were debated by aldermen. ${ }^{45}$ Alderman Farrelly moved that "in the opinion of the Council, the statements made by the medical profession .... are not borne out by the facts". Alderman Sadler moved as an amendment that "the thanks of the burgesses are due to the medical men for the interest they taken in the drainage of the town". Some aldermen, like Peter Barrett, thought the doctors were "unwarrantably" interfering: others, like Button, praised the doctors' concern for "the welfare of the community". A more interesting response came from Carter, who said the doctors' claims were "illogical". Sewage, he pointed out, had been discharged into the Tamar for about 27 years while there had only recently been an increase in the number of pails used to 600. Thus Carter argued that "it would have been far more reasonable and logical for the medical men to have given that fact as the reason for the increase of the diseases", an increase which Bushman had proved to be "imaginary". Carter concluded by saying that

44. Ibid 29 March 1887.

45. Ibid 5 April 1887. 
Surely the medical men did not suppose that the large sum that had already been expended in sewerage would be wasted, and the system stopped, whilst thousands more were to be spent in providing a new system .... It would be better for the medical men to assist the Council by practical suggestions than to rush into print with letters that can do no good but might do much harm.

Carter's reassuring arguments were well made. Sadler's motion was defeated and Farrelly's passed. The Examiner criticised aldermen for making "a dispute with regard to the best method of disposal of our sewage a personal matter between themselves and the medical men of the town". 46 The Examiner claimed that "some 25 to 30 years ago fever was almost unknown in Launceston, but now it is almost perennial in the neighbourhood of the river and along the main lines of sewer". Fever was only disappearing now because of "recent heavy rains, which have swept away deposits that have been accumulating for months past in the sewers, drains and even "in the river". On 30 May, when Bushman's report was discussed, aldermen asserted the healthiness of Launceston. 47 Farrelly said that Launceston "was gradually becoming healthy to a marked degree". Sutton thought that typhoid was declining and would decline further when "fruitful sources of disease", such as the pail system and waterwashed pits, were abolished. The triumph of the proponents of water closets was secured when the Public Health Act 1887 gave the Corporation power to enforce their use. The pollution of the Tamar by water closets was an

46. Ibid 8 April 1887.

47. Ibid 31 May 1887 . 
important issue at the municipal elections in December 1887. W.F. Wathen, who, as we have seen, was elected on an anti-Bushman ticket, was also an opponent of water closets. In January 1888 he moved that "no more water closets be allowed to flow into the sewers and thence into the river, such being contrary to section 116 of the Public Health Act [1885] and section four of the River Pollution Act". 48 The motion evoked little response and was easily defeated. The Corporation was irrevocably committed to water closets. This was determined, as Carter had intimated, by economic considerations as much as the health of Launceston.

During 1888 the sewerage system received closer attention. The Corporation continued to expend money on maintaining and extending the system. By March 1888 repairs to the Margaret Street sewer were almost completed at a cost of $£ 3,300.49$ Ventilators and gas destructors were later installed and traps were placed on water closets, as Bushman advocated, to minimise the threat of sewer gas. 50 The Launceston Sewerage Act No. 61888 empowered the Corporation to borrow $£ 25,000$ for sewerage extensions. The disposal of sewage into the Tamar and how this sewage was treated remained an intractable problem. Whenever fever cases increased the disposal of sewage into the river was blamed. In May 1890, for example, Alderman Thrower remarked that "Public interest was aroused in the sewage question, and they had better look the matter straight in the face and do their best in regard to it". 51 He moved that the Health committee report "on the best practicable means of improving the present system of discharging the city sewage into the river".

48. Ibid 24 January 1888.

49. Ibid 20 March 1888.

50. Ibid 16 April 1889, 24 November 1891.

51. Ibid 20 May 1890. 
The motion did not commit the Council to a particular course of action and, as aldermen thought it desirable to obtain information on the subject, the motion was passed. The Daily Telegraph wanted the Health committee to take "a comprehensive and thoroughly practical standpoint": it must accept the fact that "a drastic improvement" was "absolutely necessary" and that it would require "heavy expenditure". 52 A solution to the sewage problem, wrote the Daily Telegraph, was inseparable from the question of harbour improvements and the Corporation must consult with the Marine Board. In June, at a public meeting to consider harbour improvements, a motion by Alderman Edgell that the Corporation confer with the Marine Board "on all questions where the disposal of sewage affects the improvement of the port of Launceston" was carried unanimously. 53 Despite these hopeful signs, nothing appears to have happened.

As Mault's report indicated the solution to Launceston's sewerage problems was complicated and involved the sewering of Inveresk. It required a high level of engineering skill. The City Surveyor Fitzherbert prepared preliminary reports of some value but his successor Charles St. John David, appointed in March 1892, adopted a more thoroughgoing approach. Municipal engineers, like Health Officers, were one of the few qualified civic officials and played an important part in shaping the urban environment. 54 David was City Surveyor, later renamed City Engineer, for 32 years and prepared many reports on the sewerage question. As his obituary

52. D.T. 21 May 1890 .

53. Ibid 13 June 1890.

54. S.K. Schultz and C. McShane, "To Engineer the Metrcpolis: Sewers, Sanitation and City Planning in Late NineteenthCentury America", Journal of American History, v.65, 1978, p.389-411. 


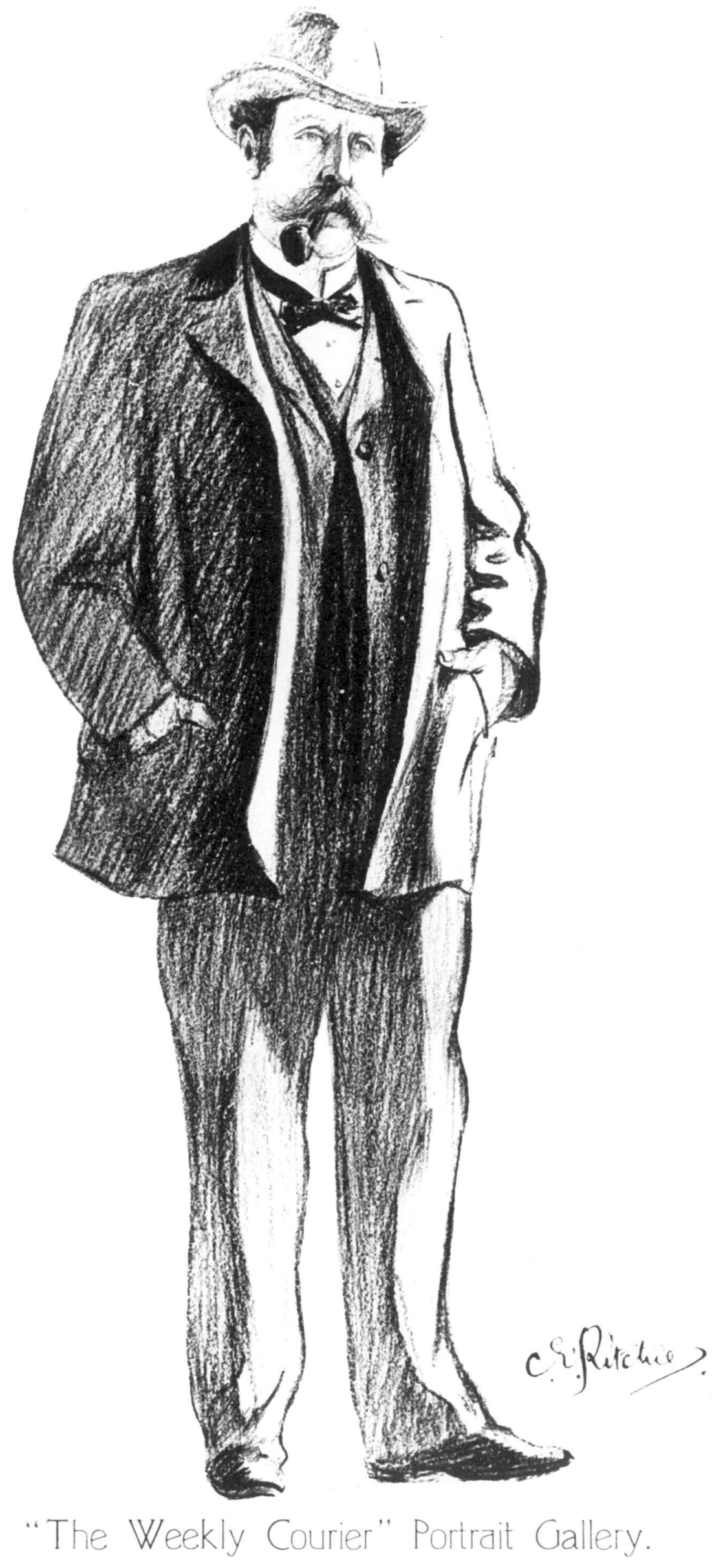


noted "That Mr. David was a professional man of wide knowledge and ability has been demonstrated by the numerous works of varied nature he has carried out successfully in Launceston". 55 A native of Chepstow in Wales, David was born in about 1856. In 1880 he arrived in Queensland, where he spent three years working for the Railway Department. He then entered a private practice as an engineer and architect. David was also consulting engineer to Booroodabin suburban municipality, "for whom extensive storm sewerage works were carried out". Thus David had the experience to recognise the problems inherent in Launceston's sewerage scheme. In September 1894 he reported on the drainage of Inveresk and followed "the general lines of Mault's suggestions". 56 He also included Invermay in the scheme because of its proximity to Launceston. No estimate of the cost of the scheme was made but with the economy aldermen in the ascendancy and the electric light scheme absorbing funds, there was little chance of it being implemented for some years. Controversy continued to surround the discharge of untreated sewage into the Tamar. In February 1898 complaints from the Captain of the bark Eden Holme that members of his crew became sick when the bark was moored near the sewer resulted in an investigation by Wilson. 57 Smells arising from sewage outlets, he wrote, were particularly offensive when the. wind blew in certain directions but "that the sewage discharge causes any increase of disease is not so certain". The evidence suggested that people living near the river and men working on the wharf were no more susceptible to diseases associated with sewage than people living elsewhere

55. Ex. $18 \mathrm{July} \mathrm{1924;} \mathrm{D.T.} 18 \mathrm{July} 1924$; A.D.B., v.8, p.217-18. 56. Ex. 18 September 1894.

57. Ibid 8 March 1898. 
in Launceston. Wilson diagnosed that only one of the four sick crewmen had a link, albeit slight, with sewage discharge. The decomposing sewage on the mud-banks might "cause a nuisance" but "This could be obviated by carrying the sewers down below high water mark". There was no agreement, Wilson concluded, on the best way to treat sewage and the septic tank system was still in the experimental stage. Thus he offered no alternative to discharging sewage into the Tamar. Later in 1898 Wilson investigated further complaints of sick sailors, but found no connection with river pollution. 58 Wilson and David continued to study developments in sewage treatment. In March 1900 Wilson noted three possibilities: sewage farms, chemical treatment or septic tanks. ${ }^{59}$ Sewage farms were "admirable" but suitable land could not always be found in cities. Chemical treatment was "expensive and in many ways cumbersome". Septic tanks appeared to be the most likely alternative and should be watched closely. For his part David was "most favourably impressed with the septic tank principle, which seems to follow natural laws".60 In May 1902 pressure from the Marine Board, which blamed the expense of dredging the Tamar on the accumulation of sewage, resulted in the Corporation reviewing sewage disposal. 61 ' Samuel Sutton persuaded his fellow aldermen that David should prepare a comprehensive report on Launceston's future drainage needs. He regarded the sewerage outlets as "the one tarnished spot in [the] municipal escutcheon" and "had heard serious complaints from people who would not murmur without cause".

58. Ibid 5 April 1898.

59. Ibid 21 March 1900.

60. T.P.P. 1901/5, p.155.

61. Ibid 3 June 1902. 
David's report was completed by October. ${ }^{62}$ He repeated in part the recommendations of Mault's report of 1886 and his own report of 1894. He believed that the quantity of sewage entering the Tamar was so small that it had "practically no deleterious effect" and "Unpleasant odours .... are not a menace to health", thereby disposing of the miasma theory of disease causation. However treatment was desirable and David recommended the construction of intercepting sewers and the use of ejectors to send sewage to a site either at River Street, near Dargan's, or, by tunneling underneath Invermay, at Stephenson's Bend. Sewage would be treated "either for clarification by means of chemicals, or purification by bacterial process". David was inclined to adopt bacterial process but as "this system has apparently not yet entirely emerged from its experimental stage", he could not make a recommendation. Plans for the drainage of Inveresk and Invermay were also included in the report. David concluded that "with the trend of modern ideas, if Launceston wishes to uphold its position of one of the foremost municipalities, some steps should be taken to bring its system more into line with accepted methods of sewage disposal". It was an appeal to civic pride and not to protect the public health. The Examiner contested David's claim that sewage disposal into the river was not dangerous because

While it may be reassuring to get another official statement as to the infinitesimal proportion of the solid matter deposited in the river in comparison to the flow of fresh water, still the City Engineer will have come difficulty in persuading many of the citizens that it is not injurious to health. 63

62. Ibid 8 October 1902 .

63. Ibid 8 October 1902. 
Even though there was "no pressing need" from the point of view of health, the Daily Telegraph favoured the proposals because the Tamar would become more "attractive as a recreation ground for the citizens and a pleasure resort for the visitors whom Launceston wants to be able to welcome in larger numbers every year". 64 Removing the outfall to further down the river would meet with general approval. However, as there was no immediate threat to health, aldermen apparently chose not to spend limited funds on sewage treatment until more conclusive proof of the success of various methods was available.

Despairing of the Council's inaction, in January 1903 the Marine Board obtained an opinion from Alfred Green on the legality of discharging sewage into the harbour. ${ }^{65}$ Green held that as the accumulation of sewage added "very considerably to the expense of cleaning and deepening the port ...." the Marine Board had grounds for complaint. According to the Rivers Pollution Prevention Act sewage could only be drained into the river if "the best practicable means for rendering the sewage harmless" was used. The" Corporation did not do this and, wrote Green, the Marine Board or any citizen could seek an injunction to stop further discharge until the sewage was purified. Informal discussions were held between the two bodies but nothing eventuated: no injunction was sought possibly because Aldermen R.J. Sadler and L.K. Fairthorne, who were also members of the Marine Board, advised against it in order to give the Corporation time to decide upon a method of purification.

64. D.T. 17 October 1902 .

65. Ex. 19 January 1903. 
It was not until October 1904 that Dr. Thomas Kenda11, a sanitary expert from the Sydney Metropolitan Board of Works, who had recently examined, the Hobart drainage scheme, was appointed to report on the Launceston sewerage scheme. 66 He described discharging raw sewage into the Tamar as "vandalism": it was "against all sanitary principles to make rivers the receptacles of the wastes of towns simply because they are adjacent and convenient ...." Sewage must be treated and Kendall favoured the use of covered septic tanks. Effluent from the septic tanks could be further broken down by passing it "on to continuous streaming filters which are constantly being aerated". This would achieve 85 percent purification. Kendall estimated the cost of installing the system at between $£ 9,000$ and $£ 10,000$ and, at an interest of five percent, the cost would be $£ 500$ per annum. Kendall then tried to estimate the economic cost of typhoid. In the first nine months of 1904 36 cases of typhoid were reported in Launceston, resulting in five deaths. Typhoid affected a patient for between six and eight weeks and the average weekly wage was $£ 1$; thus it resulted in a loss of $£ 252$. Kendall attributed $£ 150$ as the value of a life. The total cost of typhoid was thus $£ 1,022$ or "more than double the amount required to pay the interest on a properly conceived scheme of sewage disposal".

David "strongly" endorsed Kendall's recommendations, albeit differing with him on the position of the site for treatment and estimating the cost at $£ 8,000$ exclusive of sewers and ejectors. 67 To prevent "a false impression" David corrected Kendall's remarks on the number of typhoid cases: there were 21 cases, not 36 , and only one death, not five. By 1905 the finances of the Corporation

66. Ibid 4 October 1904.

67. Ibid 11 October 1904. 
were sound and the growth of Invermay and Inveresk demanded that major additions be made to the drainage scheme. ${ }^{68}$ In August 1905 David prepared a detailed report with categorical recommendations and costings. 69 Intercepting sewers would be built, and with the help of Shone's ejectors or electrically worked pumps sewage would be conveyed to Stephenson's Bend, near River Street Inveresk, where it would be treated in septic tanks. Three septic tanks, each about 120 feet by 60 feet and eight feet deep, and filtering beds about the same area, would be erected. The total cost would be about $£ 26,000$, the annual cost $£ 2,250$ and a $4 \mathrm{~d}$. rate would be required. Other necessary drainage work in Racecourse Crescent and Elphin Road would cost an additional £1,900. David's scheme for Inveresk involved reconstructing the sewer in Invermay Road to prevent rain water from entering it as "at periods of heavy rainfall .... [it was] liable to choke and flood low-lying lands adjoining". As "No system depending upon gravitation will suffice to keep Inveresk clear of flood matters during heavy rain at anything above half-tide, a pumping plant is imperative". This scheme, including pumps, would be $£ 5,000$ : an alternative proposal, to enlarge the Gleadow Street sewer to allow it to carry rain water and sewage, would cost $£ 6,500$. The drainage of Invermay would cost $£ 5,200$.

David provided aldermen with clear guidelines and any doubts he had about the use of septic tanks were now overcome. The Examiner was enthusiastic about the report. Aldermen, it wrote, were "naturally unwilling to add to the [economic'] burden of the citizens, but we fail to see how it is to be avoided if health is to be preserved and the reputation of Launceston is to be main-

68. M. 13, 20 October 1905 the views of Sadler, McCrackan and Russen when seeking power to borrow money for additions to the sewerage scheme.

69. Ex. 15 August 1905. 
tained .... It is some years since any large sum was spent on sewerage, and the growing importance of the place demands the adoption of some more healthful and up-to-date methods to deal with the problem". 70 This was also the inescapeable conclusion of aldermen. With remarkably little debate and no criticisms of note, aldermen sanctioned the work at Racecourse Crescent and Elphin Road; recommended that the Gleadow Street sewer alternative be adopted for Inveresk and that it be built to fit into the sewage treatment scheme when it was carried out; decided to approach the Town Board of Invermay to co-operate in the sewering of the area; and would seek power from Parliament to borrow $£ 25,000$ to carry out the work. 71

The borrowing powers were secured with little trouble. By December 1906 the Racecourse Crescent and Elphin Road work was completed. 72 Before constructing the septic tanks, David visited Hobart, Brisbane and Sydney to see at first hand the way septic tanks functions. ${ }^{73}$ The visits strengthened his view that septic tanks were a solution to Launceston's sewerage problems. His only reservation was that in Launceston "surface drainage runs into the sewers and that when there are heavy rains they carry a large quantity of sand and dust, which it will probably be found necessary to intercept prior to the stuff reaching the septic tank". Overflows for stormwater drainage would overcome most of the problems. The septic tank system was "an adaptation of nature's own methods of getting rid of putrefying or fermenting refuse and is now quite beyond the realms of experiment". Initially only sewage from Invermay and Inveresk would be treated in septic tanks but Thompson wanted sewage from the rest of the city to be treated. In 1909

$\begin{array}{ll}\text { 70. } & \text { Ibid } 18 \text { August } 1905 . \\ \text { 71. } & \text { Ibid } 4 \text { December } 1906 . \\ \text { 72. } & \text { Ibid } 4 \text { December } 1906 . \\ \text { 73. } & \text { Ibid } 20 \text { August } 1907 .\end{array}$


he urged in his annual report that "The treatment of the sewage of the city by bacteriolytic methods must engage the attention of the authorities in the near future, as the state of the foreshore in the neighbourhood of the Margaret Street sewer speaks for itself". 74 The Launceston Marine Board, as we have seen, had long been displeased with sewage discharge into the Tamar because it added to the cost of dredging the river. ${ }^{75}$ By 1910 the wardens were seriously contemplating port improvements and were seized with a vision of a pulsating, prosperous port. In 1911, to transform this vision into a reality, the wardens appointed a distinguished English engineer, W. Henry Hunter, to prepare detailed plans for port extensions. 76 In August 1912 Hunter completed his momentous report. The Examiner praised Hunter for his "masterly" grasp of Launceston's future needs and for the "gradual and evolutionary" character of the recommendations: if implemented the recommendations would open up "a new era" to Launceston. 77 The Daily Telegraph also gave unequivocal support. ${ }^{78}$ Public opposition was "slight". 79 In March 1913 a poll of ratepayers. of Launceston and the municipalities that would be affected by the improvements, Beaconsfield, St. Leonards, Lilydale and George Town, saw overwhelming public support for the report: 4458 voted. for going ahead with the recommendations and 606 against. 80

Not the least important recommendation made by Hunter was that the disposal of sewage into the harbour should stop. "The conditions which now obtain at some of the sewer outfalls", he

74. Ibid 29 January 1910.

75. R.A. Ferrall, The Story of the Port of Launceston, (Launceston, 1983), p.23, 41-43.

76. Ibid Chapter 10, Ex. 19 July 1911. For Hunter's career see Ex. 28 July 191 .

77. Ex. 3 August 1912.

78. D.T. 3 August 1912.

79. Ex. 22 November 1912.

80. Ibid 14 March 1913. 
wrote, "are intolerable and will become much worse from a sanitary point of view if the [Marine] board cease dredging above Town Point, as I recommend them to do, when the new harbour is completed". 81 Hunter calculated that the Marine Board dredged 14,000 tons of sewage sludge per annum from the Tamar. The Corporation should, insisted Hunter, build intercepting tanks, treat the sewage, and "arrange for the discharge of the purified effluent at some point below the new harbour and during the period covered by the first five hours of the ebb of each tide". According to the Examiner, the Corporation showed "no disposition" to follow Hunter's recommendations. 82 But as the Marine Board made it clear that future port improvements would be based on Hunter's report, collaboration was unavoidable.

Finally in April 1914 unprecedented signs of co-operation occurred. 83 David met with R.H. Garvie, the Marine Board's engineer, to prepare a combined report. Garvie had been appointed on Hunter's suggestion and had only recently arrived from England to start work on the port improvement scheme. ${ }^{84}$ In the light. of Hunter's report David revised his sewerage plans. Using intercepting sewers, all the sewage of the city would be pumped to one outfall at Home Reach "beyond the limits of the new harbour". Storm overflows, of a kind recommended by the English Local Government Board, would be used to help dilute the sewage. Both engineers agreed that "complete purification by bacteriological methods" was "altogether unnecessary" and that settling tanks would adequately dissolve the sewage. Such a system "cannot possibly have any injurious effect upon the river from the point of view of maintenance" and could not, claimed David,

81. $\quad$ Ibid 3 August 1912.
82. $\quad$ Ibid 2 May 1913.
83. Ibid 21,22 April 1914.
84. Ferrall, op.cit., p.42.


cause much objection from a sanitary standpoint, as they must be almost immediately oxidised and made harmless when mingled with the great volume of fresh and tidal waters carried by the Tamar.

David contested Hunter's estimate of 14,000 tons of sewage sludge dredged from the Tamar; it was more like 1000 tons of sewage and about 850 tons of street and animal refuse. David pointed out that the Chief Health Officer, Purdy, supported his view that objections to allowing sewage to flow into a tidal river like the Tamar were "purely sentimental" as proved by the fact that "those living near the wharves" were "particularly free" from zymotic diseases. The treatment of sewage was "not needed. If the discharge is sufficiently far from the habitable portion of the city as not to create a nuisance, I think the council is doing all that is necessary". Two septic tanks had been built to deal with sewage from Invermay and Inveresk but to treat all Launceston's sewage would require "others of larger dimensions, together with filters and other works, entailing a large expenditure, which in our case I consider unnecessary". As David had often argued

Sewage must be got rid of, as a matter of economy, in the cheapest method possible consistent with the safeguarding of the health of the community, and, .... the sewage of Launceston is in no case retained in the sewers long enough for decomposition or fermentation to take place, which change is necessary before sewer gas can be evolved or become inimical to health. 
Thompson also agreed with David. The Examiner and the Daily Telegraph, stern critics of untreated sewage disposal into the Tamar, were appeased by the reports. 85 No longer constrained by the financial requirements of the electric light and tram systems, which were working well, and faced with a proposal that was technologically feasible, acceptable to the Marine Board and that aroused no public resistance, aldermen confidently sought borrowing power from Parliament. This was granted. The Launceston Sewerage Act 1914 consolidated all sewerage loans and empowered the Corporation to borrow up to $£ 90,000$ to implement David's scheme. There were conditions. Intercepting sewers, storm overflows and storage tanks were to be built "to the reasonable satisfaction of the Marine Board". 86 Clause four was moré stringent: "The point or points of discharge of all sewage shall always be on the seaward side of Forster Street and of the wharves from time to time constructed by the Marine Board" and if the wharves were extended "further towards sea, or .... on the seaward side of Forster Street, the Corporation shall, in every such case, conduct such sewage further towards the sea" and remove storage tanks to "the seaward side of such wharves". The Marine Board had prevailed.

All was in readiness to begin work on the scheme when the First World War broke out and work was postponed indefinitely. 87 Thus the problem of untreated sewage flowing into the Tamar remained. The sewering of Greater Launceston, especially Invermay and Inveresk was the other long-standing aim of sanitary reformers: by

85. D.T. 22 April 1914; Ex. 8 May 1914.

86. Launceston Sewerage Act 1914 clauses 3 and 4.

87. As "costs were so high" it was not until 1924 that the scheme was taken up. Ex. 14 February, 4 March 1924. 
1915, "Except several outlying parts and Trevallyn", it was completed with about 32 miles of sewers laid, at a cost of $£ 86,477.88$ The extension of the sewerage system and the regular removal of refuse made important contributions to the reduced incidence of typhoid fever. Typhoid was very prevalent in the 1880 s but by the end of 1914, simultaneously with the greater attention given by the Launceston Corporation to sanitation, the death rate from it was low. (Table 11)

88. Corporation of Launceston, City of Launceston, Tasmania 1915, (Launceston, 1915), p.34 
TABLE 11 : DEATHS FROM TYPHOID FEVER IN LAUNCESTON AND RATE PER 100,000

\begin{tabular}{|c|c|c|c|c|}
\hline \multirow[t]{2}{*}{ Year } & \multirow{2}{*}{$\begin{array}{c}\text { Deaths in } \\
\text { Reg. District }\end{array}$} & \multicolumn{3}{|c|}{ Rate } \\
\hline & & City & Suburbs & Registration District \\
\hline 1886 & 25 & - & - & 131 \\
\hline 1887 & 27 & - & - & 138 \\
\hline 1888 & 30 & - & - & 144 \\
\hline 1889 & 40 & - & - & 186 \\
\hline 1890 & 14 & - & - & 65 \\
\hline 1891 & 11 & - & - & 51 \\
\hline 1892 & 13 & - & - & 59 \\
\hline 1893 & 8 & - & - & 36 \\
\hline 1894 & 7 & - & - & 31 \\
\hline 1895 & 10 & - & - & 43 \\
\hline 1896 & 9 & - & - & 38 \\
\hline 1897 & 11 & - & - & 45 \\
\hline 1898 & 9 & 44 & - & 36 \\
\hline 1899 & 1 & 5 & - & 4 \\
\hline 1900 & 2 & 6 & 31 & 10 \\
\hline 1901 & 4 & 17 & 31 & 19 \\
\hline 1902 & 3 & 17 & - & 14 \\
\hline 1903 & 5 & 22 & 30 & 23 \\
\hline 1904 & 2 & 6 & 30 & 9 \\
\hline 1905 & 2 & 5 & 30 & 9 \\
\hline 1906 & 11 & 60 & - & 51 \\
\hline 1907 & 5 & 16 & 6 & 23 \\
\hline 1908 & 8 & 35 & - & 33 \\
\hline 1909 & 13 & 48 & 10 & 53 \\
\hline 1910 & 19 & 42 & - & 84 \\
\hline 1911 & 6 & 19 & - & 26 \\
\hline 1912 & 4 & 14 & - & 17 \\
\hline 1913 & 2 & 5 & - & 8 \\
\hline 1914 & 7 & 14.1 & - & 29 \\
\hline
\end{tabular}

Source: J.H.L. Cumpston and F. MacCallum, The History of the Intestinal Infections (and Typhus Fever) In Australia 1788-1923, (Melbourne, 1927), p.729 and Statistics of Tasmania. 


\section{CHAPTER FIVE}

\section{VESTED INTERESTS}

Ridding the environment of wastes and their accompanying odours made city life much more pleasant and healthy. However for those residents living in an insanitary house, near a foulsmelling noxious trade or a defectively drained cemetery and working long hours in a poorly ventilated factory city life held few charms. The efforts of the Launceston Corporation to rectify these evils were beset with difficulties. Vested interests, accustomed by the laissez-faire climate of the nineteenth century to being able to do as they liked, resented and resisted municipal intervention in various ways. Even when aldermen showed a determination to overcome this resistance, they were sometimes hampered by inadequate legislation. Then vested interests used their influence to prevent Parliament from providing the Corporation with stronger powers. Thus, as we are about to see, achievement was at best halting.

a) Housing

The locus of much disease in the nineteenth century city was insanitary housing. Defective drainage, crumbling walls, an absence of plumbing, lack of ventilation, dampness and overcrowding contributed to sickness and death. Strict supervision of building standards was a central duty of local government but, according to Dyos and Reeder, in England, "the history of building

1. For England see A.S. Wohl, The Eternal Slum: Housing and Socia1 Policy in Victorian London, (London, 1977). For Sydney see A.J.C. Mayne, "City Back-Slums in the Land of Promise: Some Aspects of the 1876 Report on Overcrowding in Sydney", Labour History, No. 38, 1980, p.26-39 and S.H. Fisher, "An Accumulation of Misery?", Labour History, No. 40,1981, p. $16-28$. 
regulations is a tale of regulators never quite catching up with the builders...." ${ }^{2}$ This was also true in Launceston and Hobart. In 1892 Alfred Mault added another dimension when he wrote that "my experience of colonial life shows me that the great want is not provision of good laws and regulations [for buildings] but of a steady determination to enforce them". ${ }^{3}$

The enforcement by the Launceston Corporation of the Launceston Building Act 1869 fluctuated between periods of activity and dormancy. As we know from about 1883 the Corporation began to, apply the Act more consistently. In 1886, for example, 32 houses were condemned. ${ }^{4}$ The tension between safeguarding the health of the city and considering the impact demolition would have on the owners and inhabitants of dilapidated housing was ever present. In May 1887 the Town Surveyor Fitzherbert compiled a list of houses to be demolished and sought aldermanic assent to go ahead. 5 Alderman Sutton thought "for the health of the people and of the town at large .... they should be immediately dealt with". Henry Button knew that Fitzherbert took great care to be just when "dealing with buildings of this character" and Button did not want "old buildings to remain in Launceston to be nurseries of disease", but the Corporation "must be cautious .... so as to effect the improvements with as little harshness as possible and without invoking magisterial intervention". Aldermen gave Fitzherbert their assent.

2. H.J. Dyos and D.A. Reeder, "Slums and Suburbs" in H.J. Dyos and M. Wolff (eds.), The Victorian City: Images and Realities, (London, 1973), v. 1, p.364.

3. A. Mault, "Urban Sanitation", Australasian Association for the Advancementof Science. Report of 5th Meeting, v.5, 1893, p.188.

4. Ex. 7 December 1886.

5. Ibid 31 May 1887. 
In July 1887 G.T. Matthews appealed to the Mayor, Robert Carter, against a decision to demolish his house in Wellington Street. ${ }^{6}$ Carter stressed that demolition was only ordered "after long and careful consideration and the health, progress and wellbeing of the community demanded that to the determination so arrived at the Council should firmly adhere". The Daily Telegraph, which often advocated the demolition of unsightly buildings, praised aldermen for enforcing the legislation as it had resulted in "almost re-building and beautifying some portions of Launceston which, a few short years ago, were a disgrace to a Chinese back slum". 7 Aldermen were "at all times most lenient, equitable and considerate" in their approach. When the Town Surveyor brought dilapidated houses to the attention of the Corporation, members of the Health committee personally inspected each house before deciding in favour of demolition or repair. Demolition was "not very palatable" to the owners of decaying buildings "some of whom, beyond a few splashes of a whitewash brush, and a pane of glass, scorn the idea of repair" and cried "tyranny and despotism" when the law was applied. The Daily Telegraph hoped the Corporation would continue to support the Town Surveyor and get rid of "many of the shanties still in existence, witha view of not only beautifying the town, but of attending to the convenience, comfort and health of its inhabitants".

The Daily Telegraph hinted at a weakness of the legislation. The legislation was permissive and aldermen were not compelled to order demolition or repair. If aldermen lacked the conviction to enforce the law, then the reports of the Town Surveyor were

6. Ibid $26 \mathrm{July} 1887$.

7. D.T. 2 August 1887. 
useless: he could not take independent action to order demolition. Aldermen who were landlords or involved with the building trade might be reticent to act: self-interest would overrule health considerations. Decisions whether to demolish or not also entailed a moral consideration. In June 1887 "J.P.C.", writing to the Examiner about tine decision to pull down insanitary buildings, agreed "That thosehabitations are an eyesore and inimical to health ....; but the question arises and a serious one it is - Are these people to be thrown onto the street, are they to burrow in the ground like rats, or occupy the gaol, because their means do not allow them to occupy a better class of house?...." 8 Some of the "dog kennels about to be pulled down" were rented at $8 \mathrm{~s}$. weekly and rents for similar levels of housing were often much higher. Low wages in proportion to high rents forced many Launcestonians to live in insanitary housing. "J.P.C." remarked that, as speculators would not build houses at low rental for the working class and poor, it was "the duty of the State or the municipalities" to do so. "J.P.C." outlined a detailed scheme for the Launceston Corporation to build 100 cottages at a cost of $£ 20,000$. This was one of the few notable proposals for municipal housing before 1900 but aroused little interest. ${ }^{9}$ More serious proposals were floated after 1900 and will be considered later in this section.

Aldermen were also sensitive to the moral considerations of demolition. In November 1887 this was illustrated when Alderman Scott asked that four weatherboard houses in William Street, owned by a Mrs. Bryants, be repaired and not demolished. ${ }^{10}$ The

8. Ex. 16 June 1887.

9. In 1885 the Daily Telegraph exhorted the Corporation to build houses D.T. 11, 27 June 1885 .

10. Ex. 15 November 1887. 
houses were let "at a low rental, and tenanted by poor people who would have difficulty in procuring residences elsewhere". By pulling down decaying houses the Council would consign the poor to even worse circumstances, such as overcrowding. Carter refused to yield but pointed out that if owners presented the Council with a certificate from a recognised builder that the properties were not beyond repair, they had the right of appeal. Whether Mrs. Bryants was as philanthropic as Scott made her appear, her case did raise an important issue. It indicated that not all landlords were avaricious, relentlessly seeking a high return on housing investment. Some could play a socially responsible role by keeping rents low for sub-standard housing and aldermen had to take this into account. The appeal mechanism afforded property owners some protection. In August 1888, for instance, John Blackburn protested against a decision to demolish his cottage property in Lower St. John Street, presentıng aldermen with certificates from Doctors Stewart and Murphy stating that it was fit to inhabit. 11 Adye Douglas visited the cottage and thought that, "although not ornamental, it was dry and sound". Fitzherbert had provided aldermen with another long list of dwellings to be condemned but, said Douglas, "the effect of condemning houses in such a wholesale manner in a small community would be to induce the evil of overcrowding - a fruitful source of disease". Most aldermen agreed with Douglas and orders to demolish Blackburn's property, and two other properties, were revoked. ${ }^{12}$ The Examiner supported Douglas. It wanted all aldermen and not just members of the Health committee to inspect the Town Surveyor's 1ist of buildings to be condemned. 13 It averred that

11. Ibid 7 August 1888 .

12. Ibid 14 August 1888 .

13. Ibid 7 August 1888. 
Whilst the welfare of the community must be consistently studied in relation to the enforced removal of insanitary dwellings, this must be done only after painstaking and reliable investigation. Generally aldermen were careful, and at times timid, in the application of their powers. In his half yearly report of 1889 Bushman noted that in the past five years only 140 dilapidated houses were demolished but this was more than in any other period. ${ }^{14}$ From 1883 to 18901404 houses were "dealt" with, that is either repaired or demolished. ${ }^{15}$ Given Launceston's small population this was a solid achievement and showed that the interests of property owners were not always paramount.

Aldermen appeared to soften their approach with the onset of the depression and demolition was ordered only in extreme cases when health considerations demanded it. ${ }^{16}$ The Corporation demonstrated greater concern with ensuring that new housing reached an acceptable standard. In April 1889 a by-law was passed making compulsory the erection of damp-proof basements "so as to render the foundation of such building, and the ground over which such building is to be placed, dry, sound and well drained, so that no water soakage or damp shall lodge there". ${ }^{17}$ In 1891 this by-law was amended to make sure the damp-proof material was "well rammed and smoothed, and when finished not less than two inches in thickness."18 At annual conferences, on motions by Launceston aldermen,

14. Ibid 1 October 1889.

15. Ibid 3 February 1891.

16. For example see Ibid 19 September 1893.

17. Hobart Gazette, 28 May 1889, p.1033.

18. Ibid 23June 1891, p.1157. 
the Hobart and Launceston Corporations voted in favour of powers to compel builders to submit plans for roads and drains to local authorities for approval before building began, as provided in the Sydney Improvement Act 1879. ${ }^{19}$ The Examiner thought that such legislation was necessary because "the good government and health of the people are being menaced by subdivision and overlapping of properties now going on in some parts of the city", mainly in the outer suburbs, where drainage was often neglected. 20 The Public Health Act 1889 embodied the powers and in March 1890 the Launceston Corporation passed by-laws regulating the width of streets. $^{21}$ Finally the Launceston Building Act 1894 empowered the Corporation to prevent "dwelling-houses below the annual assessment to be fixed by the Council" from being built in certain areas of the city and included clauses relating to the size of rooms. Wilson rarely reported on the major structural defects of housing, realising that many house-owners could not afford the improvements. He aimed to keep houses clean and to remedy defective drainage. As many houses were drained in Launceston, seeking out defects consumed much time. One requirement was the ventilation of sewers by shafts on the outside of houses otherwise

they will ventilate themselves into the interior of such houses as have faults in their drains, and it is equally certain that sewer air is an important agent in the propagation of infectious dis-

19. At the 1888 conference the motion was moved by Sam Sutton M. 19 April 1888. For the Sydney Improvement Act see G. Gerathy, "Sydney Municipality in the 1880s", Royal Australian Historical Society Journal, v.58, 1972, p.23ff. and A.J.C. Mayne, Fever, Squalor and Vice: Sanitation and Social Policy in Victorian Sydney, (St. Lucia, 1982).

20. Ex. 18 March 1889.

21. Hobart Gazette, 20 May 1890, p.844-45. 


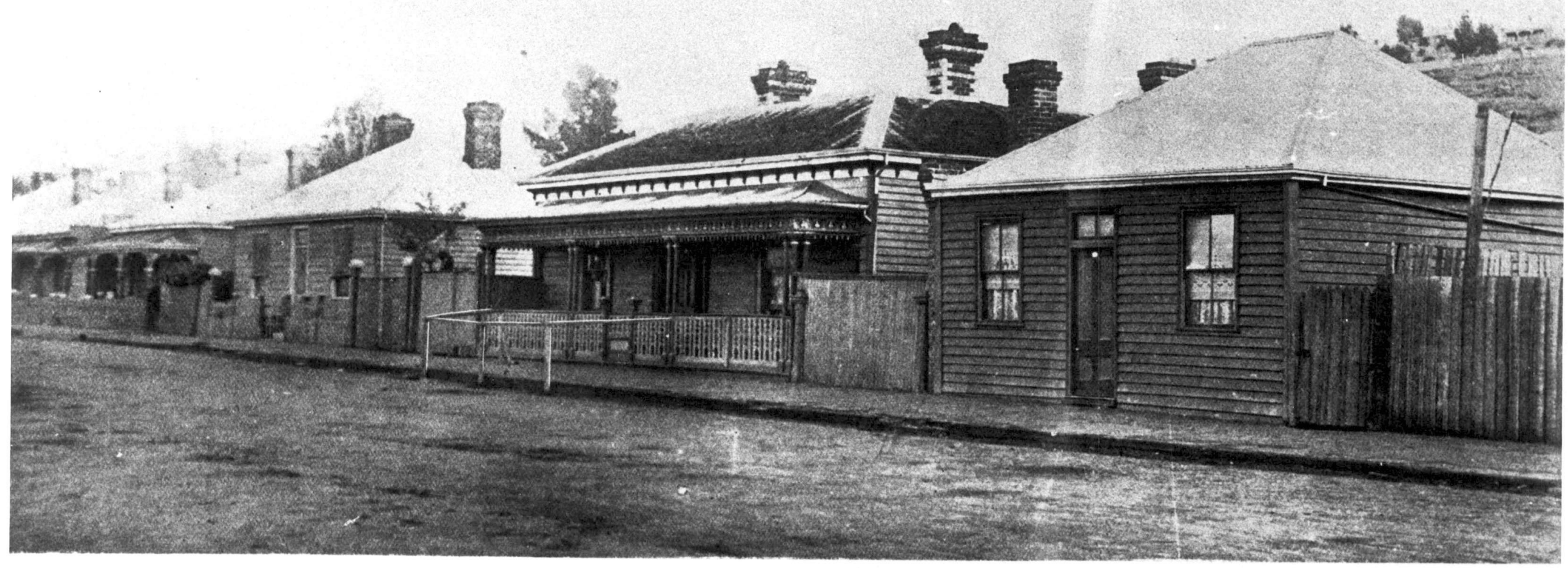

RE-IDENCE OF THE COA FAMILY, MARAIARET STREET, WHERE THREE CASES OCCURRED. (The houses indicated are those with temporary railings erected outside) SMALL POX OUTBREAK IN LAUNCESTON. 
eases, though whether it does so by conveying the germs directly or by merely weakening the constitution is still a debateable question. 22

In 1901 Wilson told the Royal Commission on the Municipal Government of Hobart and Suburbs that if, "in the case of .... [his] professional round", he found a house with faulty drainage I should regard it as my duty to serve a notice at once on the landlord of the property, and have it put right. We do things in a very summary way up here, I can assure you. If such a case is not put right in three days, the work is done by the Municipal Council, and charged to the landlord. We don't wait very Iong; we have not got time up here in Launceston, as a matter of fact. 23

This approach to insanitary housing was continued and extended by Thompson, who regarded "the defence of the home" as "a prime factor in the preservation of health". ${ }^{24}$ In his 1905 annual report he concluded that "many of the houses are insufficiently ventilated". 25 When doors and windows are closed, the houses were, "in the absence of a chimney", not fit to inhabit and were "sealed boxes". Thompson indicated the perils for tenants if owners were forced to obey the law. When infectious diseases cases were found in premises, landlords were ordered to make repairs or alterations "but the tenants have been made to suffer, as they have been expelled by the owners in more than one instance". In Thompson's first full year as Health Officer

22. Ex. 21 February 1899.

23. T.P.P. 1901/5. p.162.

24. Ex. 9 February 1909.

25. Ibid 6 February 1906. 
"Many improvements" were effected and "some" of the dilapidated houses were demolished. 2635 cases of enteric fever or 47 per cent of all cases occurred at Inveresk and 12 of these cases were located "in certain poorly ventilated crowded back-to-back houses at the South angle of the Gunn-Gleadow streets intersection". Dampness, which contributed to tuberculosis, was a common problem: the "severe" winter rains "proved that the making of a weatherproof building is practically a lost art" as "in numbers of modern structures water passed through the roofs and walls to the discomfort and annoyance of the inmates". Too little attention was given to the hygiene of the kitchen, "the source of all disease", and it was "lamentable to find the maid's or other bedroom communicating directly therewith". It was "filthy" to use "a combined wooden kitchen sink and laundry" and "when one finds the culinary apparatus exposed to the contamination of cast-off body linen, he' is never surprised to learn of the members of the household suffering from bacterial infection". 27 Thompson often warned residents of the dangers of such practices.

Thompson advocated a tough line against unscrupulous land1ords:

the owner of an insanitary house, with the full knowledge thereof, who postpones and delays alterations and repairs, deserves as little consideration as does the retailer of unsound or unwholesome food; the tenant or sufferer from any such negligence would have no difficulty in enlisting the sympathies of a jury. 28

26. Ibid 2 February 1907.
27. $\quad$ Ibid 10 January 1911.
28. Ibid 2 February 1913. 
Landlords avoided detectıon by making "trumpery repairs". In some cases bricks that were "tainted with saline matter", after being ordered to be removed from one house, were "used to build another of the same description". 29 Defective house drainage continued to make "very many occupiers" vulnerable to sewer gas, 30 Thompson estimated in 1910 that "Many of the older houses - probably 100 - must disappear within the next decade, and accommodation provided for three or four hundred people".

The Daily Telegraph did not deny that the Corporation intended to rid the city of dilapidated and insanitary housing but it was hamstrung by inadequate laws that could be easily evaded. 31 Property owners "kept just without the range of the regulations" and "a thick coat of paint covers a multitude of sıns". Parliament should "extend the scope of municipal supervision over dilapidated properties". The Examiner concurred that the law was inadequate, pointing out that "Most of the insanitary dwellings into which the poorer classes are crowded are the result of inefficient building regulations in past years". 32 It contended, however, that the Corporation was reluctant to apply the powers at its disposal: "vested interests evidently prevent our aldermen dealing with" insanitary housing. 33 The Examiner felt there was "too much mistaken sympathy for the owners of insanitary and dilapidated buildings", which generated so much disease. 34 These owners "should be more rigorously dealt with". The Building Act should also be strengthened to limit the overcrowding of "the greatest number of tenements into the least possible space" as

29. $\quad$ Ibid 21 January 1913.
30. $\quad$ Ibid 10 January 1911.
31. D.T. 12 May 1911.
32. Ex. 28 Ju1y 1913.
33. $\quad$ Ibid 23 May 1910.
34. $\quad$ Ibid 24 January 1912, 10 November 1913.


this resulted in "pocket-handkerchief backyards". 35 The Examiner regarded town planning as a panacea to stop "the growth of slum localities" in the future. Without doubt one of the first things that should be considered in the creation of a town is its planning .... Every town and city should have plans of future extensions drawn out, and landowners should be compelled to conform to them in cutting up areas. 36

Letchworth was cited as an example of the success of town planning: the Daily Telegraph, which was not yet as enthusiastic about town planning as the Examiner, was impressed by the Hampstead Garden Suburb. 37 However town planning seems not to have been discussed by aldermen. On the whole aldermen were circumspect in their approach to insanitary housing, in part not wishing to alienate property owners and also because of the absence of cheap and sanitary alternative accommodation. It is time now to consider the availability of housing.

In the years after federation Launceston, like Hobart, experienced a building boom. In 1911 the Daily Telegraph wrote that there was "no breach in the continuity of the boom in building launched more than five years ago". 38 All kinds of buildings were being built: "big roomy shops for the city, villas in the suburban radius, whilst cottages are springing up in the suburbs".

35. Ibid 23 May 1910, 28 July 1913.

36. Ibid 10 November, $28 \mathrm{July}$ 1913. For the impetus given by insanitary housing to the adoption of town planning see J.N. Tarn, "Housing Reform and the Emergence of Town Planning in Britain before 1914" in A. Sutcliffe (ed.) The Rise of Modern Urban Planning 1800-1914, (London, 1980), p.71-98.

37. D.T. 19 September 1914. For the influence of these two schemes in Australia see R. Freestone, "The Garden City Idea in Australia", Australian Geographical Studies, v.20, No. 1, 1981 , p. 24-48.

38. D.T. 16 March 1911. 
At the same time, observed the Daily Telegraph there existed "a great scarcity of dwelling houses of four or five rooms". 39 A leading house and land agent explained that "capitalists during the past three or four years have ceased speculating in house property" of that size, usually rented at between $10 \mathrm{~s}$. and $15 \mathrm{~s}$. per week. After interviewing other agents and those working in the building trade the Daily Telegraph confirmed that, despite the boom, "The provision of workmen's dwellings has not been and is not now regarded with much favour by people who have money to invest". 40 This was also true in Hobart, as we will see, and the same reason was given: the high cost of land in suitable locations, - of labour and of material. ${ }^{-}$Thus, to achieve a satisfactory return on investment, speculators had to charge high rents, which the average worker could not afford.

In Launceston charitable bodies and philanthropic citizens were not as active as in Hobart in attempts to solve the housing shortage. It was to the Launceston Corporation, because of the "spirit of enterprise and progress" shown by it "in matters affecting the welfare of the citizens", that most people turned. 42 In March 1903 "Congested Launceston", complaining to the Daily Telegraph of the dearth of housing, considered that the Corporation would be "justified in providing houses as they are in providing water, lighting etc.... There are also hygienic reasons why the Council should step in, for numbers of the dwellings of the poorer classes are unfit for habitation, being badly built, in bad positions, dirty, draughty and breeding

39. Ibid 2 August 1911

40. Ibid 3 August 1911.

41. Ibid; Ex. 9 December 1912, 7 January 1914.

42. Ex. 16 July 1904 
all manner of illnesses". 43 In April the Daily Telegraph interviewed the Mayor, David Storrer, for his views on the housing problem. ${ }^{4}$ " Storrer "frankly expressed himself as in some degree favourable to a sound system of municipal housing". He pointed out that the Corporation had built workmen's cottages at the electric power station for municipal employees and a house in Paterson Street "was yielding rent to the citizens". Some aldermen, aware of the housing shortage, favoured building cottages on land near the reservoir, recently purchased by the Corporation. Storrer was "strongly in favour of several municipally-owned residence sites being built upon, but was not sure .... that the prospect of the Council extending its sphere of usefulness as a landlord would meet with universal favour".

Further publicity was given to municipal housing in July 1904 when a reporter on the Examiner, "Ren", wrote a series of articles on how the poor lived in Launceston. ${ }^{45}$ While denying the existence of slums as existed in London or Sydney, "Ren" was shocked by the poor quality of housing, for which "exorbitant" ' rents were charged. People were living "under conditions little better than .... animals" and the houses were "a disgrace to civilisation". "Ren" believed that in Launceston "much of the intemperance is caused by .... wretched surroundings". "Ren" described the housing schemes of the London County Council and wondered if the Launceston Corporation could provide housing "for those who are dependent upon a small wage". 46 "Huts", writing to

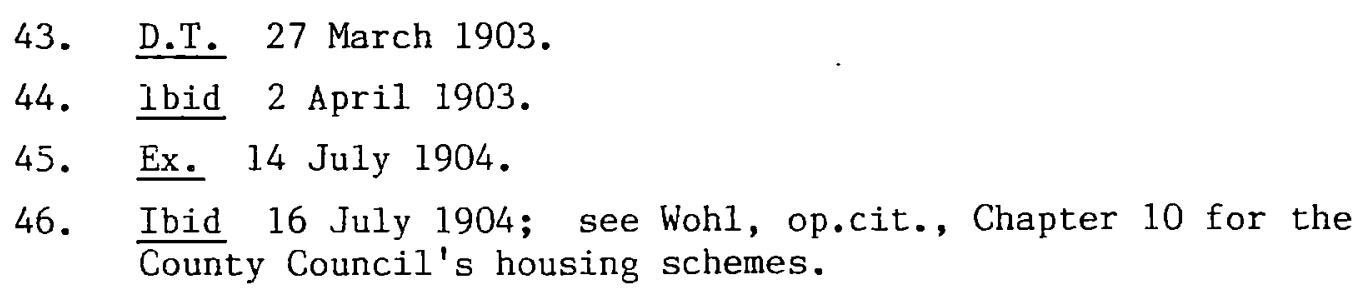
County Council's housing schemes. 
the Examiner, claimed that, after a decade of discussion, "the desirability of [municipal landlordism] .... is freely conceded", particularly for "the miserably housed poor". 47 On 18 July the housing problem was raised in the Council. 48 Alderman Sutton, who was also chairman of the BenevolentSociety, said "Ren's" articles accurately portrayed housing conditions in Launceston "as many of the so-called houses in which the poor of the city lived were the scenes of squalor and misery". Aldermen "touched upon" municipal housing; it was noted that the Corporation owned land in different parts of the city and with $£ 4,000$ could make some headway in relieving the housing shortage. The Examiner opposed "the suggestion that the corporation should enter into competition with the building trade" and favoured a more rigorous policy of removing the "disease-breeding hovels, which are a blot on the fair name of the city". ${ }^{49}$ Although some attempt was made to deal with insanitary housing, it was not accompanied by a rehousing programme. 50

The most fully developed scheme for municipal housing was proposed by Henry Button, no longer an alderman, in October 1905. 51 He noted the "sporadic interest" in the provision of "better and cheaper dwellings for workıng men and others in receipt of small incomes" but the interest had not be sustained to the point of practical action. The cost of construction stunted action, but if a scheme was begun "on an extensive scale", costs would be lowered and only the Council had the borrowing powers to build
47. Ex. $18 \mathrm{July} 1904$.
48. Ibid $19 \mathrm{July} 1904$.
49. Ibid 22 July 1904.
50. Ibid 28 March 1905.
51. Ibid 17 October 1905. 
on a large scale. Button proposed that the Corporation seek legislative authority to appropriate land on Windmill Hill as building sites. Allotments would be leased for 50 years or longer and plans would have to be approved by the Council. He went on:

During the currency of the leases the ground rents would go into the municipal exchequer; as the leases fell in the houses would become the property of the corporation, the full annual rentals then forming a magnificent addition to the municipal revenue of that day - and the best of it is, no-one would be a penny the worse. The charming and healthy position would ensure eager tenants.

A similar scheme could be employed on part of the Benevolent Asylum's grounds fronting on Paterson Street and running down to the Esplanade. The combined area of the two sites was about 2,000 feet. 24 allotments of 50 feet frontage and 20 allotments of 40 feet frontage could be carved out. If a ground rental of $£ 8$ each was charged the Council would receive $£ 352$ per annum. Houses should be "plain, neat but substantial cottages of different sızes, varying from at least three or four, to seven or eight rooms". They should be built of brick, stone or concrete and have a bathroom, pantry and laundry, which were "indispensable in the interests of morality and sanitation. Not more than two cottages should be conjoined and all should have enough ground for a small garden". Rent should not be more than from 5s. to 10s. a week. Whatever scheme was undertaken it must not take on "the character of almshouses": the cottages "must be erected on distinctly business principles" and "be absolutely self support- 
ing". Everyone admitted to "the importance of the housing of the poor" and Button urged that his, or some other scheme, be implemented.

Button's scheme appeared to be economically feasible and should have stimulated debate on municipal housing but it did not. In December 1905 Button lamented to the Examiner that his scheme had "not evoked the slightest discussion, or, more marvellous still, the faintest protest". 52 Apart from a thoughtful letter by E.L. Bailey, who noted that "the financial aspect" was "the most serious impediment", interest in municipal housing remained confined to sentimental theorising, while other housing reformers merely dwelt on the misery and immorality caused by overcrowding. 53 Odd letters to the press in subsequent years reminded the Corporation of its duty. In August 1911, for example, "Peter Simple" exhorted the Corporation to build working class housing, mainly because it could acquire land cheaply. ${ }^{54}$ It could not be argued, added "Peter Simple", that the Corporation. would be competing with private enterprise because the house famine showed that private enterprise was no longer attracted to this kind of housing. This was a seductive argument and if the Launceston Corporation had embarked on a scheme of municipal housing it would have been the high-water mark of municipal intervention. However, as the Examiner had intimated, direct competition with the building trade was stretching municipalisation further than aldermen were prepared to go or than vested interests would

52. Ibid 2 December 1905 .

53. Ibid 7 December 1905 and, for Button's rejoinder, 8 December 1905.

54. D.T. 8 August 1911. 
let them go. Doubts about the profitability of such an enterprise also worked against municipal action. One of the reasons why the municipal tram system was advocated was to open up cheaper land in the suburbs and stimulate building. There were signs that this was happening but by the First World War the housing shortage had not been overcome. 55

b) Noxious Trades

The environmental problems created by noxious trades were common in cities and were associated with the miasmatic theory of disease. 56 Stinks arising from noxious trades, such as tanneries or bone boiling works, assaulted the noses of city residents and industrial wastes polluted rivers and streams, prompting demands that noxious trades be regulated by City Councils or moved to another locality. Although noxious trades could present a real threat to health, it was the effect of smells or smoke on the aesthetic enjoyment of the environment and residential comfort that aroused most complainants. 57 In seeking to have these trades moved to specially designated areas, city residents were also exhibiting what Peterson has called a "townsite consciousness" that was one contribution made by sanitary reform

55, Ex. 3, 4 February 1914; D.T. 4 June 1914.

56. For noxious trades in British cities see C. F1ick, "The Movement for Smoke Abatement in 19th-Century Britain", Technology and Culture, v.21, No. 1, 1980, p.29-50 and A.E. Dingle, "The Monster Nuisance of Al1': Landowners, Alkali Manufacturers, and Air Pollution, 1828-64", Economic History Review, v.35, 1982, p.529-48. For Australia see S. Fisher, "The Pastoral Interest and Sydney's Public Health", Historical Studies, v.20, No. 78, 1982, p.73-89; B. Barrett, The Inner Suburbs: The Evolution of an Industrial Area, (Melbourne, 1971), Chapters 6 and 7; and T.G. Parsons, "Manufacturing on the Banks of the Yarra River, Melbourne: The Development of an Industrial Area", Journal of Australian Studies, no.11, 1982 , p.2l-35.

57. F.M. Jones, "The Aesthetic of the Nineteenth Century Industrial Town" in H.J. Dyos (ed.), The Study of Urban History, (London, 1976), p.173. 
to the town planning movement of the early twentieth century. 58 First the way the Corporation dealt with its own noxious trade, the city slaughteryard, will be briefly examined before moving on to its regulation of privately owned noxious trades.

The nuisance created by the Launceston slaughteryard did not offend public sensibilities to the extent that the Hobart slaughteryard did. When it was first built, at the corner of Balfour and Upton Streets, few people lived near it but, as the city grew and residences were built in the vicinity, complaints of smells from the slaughteryard became more frequent. A "townsite consciousness" developed that a slaughteryard, whatever the convenience for butchers, had no place in a modern city. In 1885800 burgesses requested that the Corporation move the slaughteryard to the reserve on the Swamp. 59 The Slaughterhouse committee. considered removal "desirable" but were too put off by the cost to recommend it. Persistent complaints by property owners that the existence of the slaughteryard prevented further residential growth resulted in a more thorough report in June 1886.60 The slaughteryard, claimed the report, was characterised by "the utmost cleanliness". There was "no effluvium from the establishment injurious or even unpleasant to the public" and "the great cost involved [in moving to a new site] would far outweigh any supposed advantages". Later in 1886 Alfred Mault, who had harsh words for the Hobart slaughteryard, visited Launceston and confirmed the clean character of the slaughteryard. ${ }^{61}$ Various improvements

58. J.A. Peterson, "The Impact of Sanitary Reform upon American Urban Planning 1840-1890", Journal of Social History, v.13, No. $1,1979, \mathrm{p} .91-4$.

59. Ex. 2, 9 June 1885.

60. Ibid 8, 15 June 1886 .

61. T.P.P. 1886/139. 
were made to the slaughteryard by Bushman and Wilson but neither considered removal to be urgent.

The slaughteryard received more attention when Thompson became Health Officer. In August 1905 he reported that its existence in the centre of the town was inconsistent with established sanitary principles and recommended that "a properly equipped abattoirs" be built "out of town, and .... in touch with a railway line". 62 Failing that he suggested alterations to the slaughteryard but aldermen were unresponsive. As a reporter to the Examiner later wrote: "What is the matter with the Launceston site, when there is no nuisance, no complaint and where any little defects can be remedied with a slight outlay". ${ }^{63}$ In 1913 the slaughteryard was "thoroughly"renovated, a new system of drainage was laid and a much needed new method of dealing with offal was introduced. 64 With measures such as these the Corporation was able to control nuisances arising from the slaughteryard and prevent residents in the vicinity from being inconvenienced to any great extent. Other noxious trades provided the Corporation with many more problems and raised more fundamental issues about its role in the city. The Corporation had to chart a difficult course between protecting the public health on the one hand and stimulating the growth of industry on the other.

As we have seen the Launceston Offensive Trade Act 1874 gave the Corporation power to regulate noxious trades. 65 This

62. Ex. 19 August 1905.

63. Ibid 23 June 1906.

64. Ibid 14 October, 9 December 1913.

65. see M. Morris-Nunn and C.B. Tasse11, Launceston's Industrial Heritage: A Survey, Part One, (Launceston, 1982), passim for information on noxious trades and other industries in. Launceston. 
was the only local Act specifically relating to such trades. The provisions of the Public Health Act 1885 applied to noxious trades throughout the colony. The provisions were more detailed and empowered private citizens to bring action against any trade that proved troublesome. By clause 98, for example, if two doctors or 10 residents complained about a noxious trade to a Local Board of Health, it was categorically stated that the Local Board "shall cause complaint to be made before a Justice". By clause 105 an individual could complain directly to "a Justice". Thus a defaulting or dilatory Local Board would be bypassed by aggrieved residents.

One of the earliest applications of the Public Health Act involved a noxious trade, Ditcham's Bone Mill. When the Bone Mill began operations in 1866 it was surrounded by a cemetery to the south, a church glebe to the north, iron manufactories to the east and rocky bush to the west. In subsequent years the glebe was cut up into small allotments and sold as building ground. 66 By 1886 houses had been built over much of the area. As was the case with the slaughteryard and other noxious trades, the Bone Mill became a nuisance as the number of people living near it increased. Residents joined "land speculators with eligible sites in the vicinity" to force their removal. ${ }^{67}$ Repeated complaints resulted, in May 1886, in the Corporation giving Ditcham one month's notice to abate the nuisance. ${ }^{68}$ The Corporation also intended taking action against a bark mill and a guano store. ${ }^{69}$

66. D.T. 15 December 1888.

67. Ex. 25 September 1889.

68. Ibid 1 June 1886.

69. D.T. 11 June 1886. 
Some attempt at regulation was made in August 1887 when a by-1aw was passed making it compulsory for every. noxious trade that discharged refuse to provide "a receptacle or reservoir for receiving and retaining such refuse". 70 The receptacle was to be kept "securely covered and in an inoffensive condition and .... periodically emptied": when emptied the contents were to be "deodorised and all precautions taken to prevent any effluvium".

The economic consequences of too stringent an enforcement of the noxious trades clauses of the Public Health Act did not go unnoticed. When noxious trades were first established, observed the Examiner, "they were hailed as benefactors to the community for introducing or extending local industries, giving increased employment to labour, turning waste products into marketable commodities and thereby increasing the commerce and the material wealth of the community". 71 Now people were prepared to close down trades, such as tanneries, because they emitted "unsavoury odours" but not "every unpleasant smell is necessarily injurious". 72 The Examiner conceded that "Conservation of the public health should be the first consideration but a community that is straining every nerve to get to the front in the commercial race must not be more fastidious than its rivals". Two defects in the legislation were noted. No provision was made for compensation to owners of noxious trades who were forced to close down, or for the establishment of a noxious trades area where businessmen could "invest their capital and pursue their business with confidence". 73 The Daily Telegraph also pondered on the effects the legislation would have on local industries. It regarded manu-

70. Hobart Gazette, 18 October 1887, p.1566.

71. Ex. 25 September 1889.

72. Ibid 28 May 1886.

73. Ibid 22 June 1886, 25 September 1889. 
facturing industries as essential for economic stability:

Manufactures when once established are usually

permanent, are less subject to vicissitudes than

the mining, pastoral or agricultural industries;

and consequently possess a stamina which is of

great value to the country in which they flourish. 74

Population growth was also fostered. People tended to concentrate in towns and "if they cannot find employment in the towns of one Colony, even though it be their native land, they will emigrate and take up abode in some of the continental centres of population". This was especially pertinent to Launceston because "beyond a few trades and professions - very limited in their requirements - there is practically nothing for the young men of Launceston to do but crowd into the inevitable clerkship or emigrate". 75 If too frequent use was made of the noxious trade clauses of the Public Health Act "the few manufacturers we have will be driven out of the Colony and others will take good care to keep clear of Tasmania". 76 The Daily Telegraph also bemoaned the absence of a compensation clause. 77

Subsequent amendments to the Public Health Act gave local bodies power to proclaim a noxious trades area and gave owners who were forced to close down the right to claim compensation. 78 How these changes created new pressures for Corporations in their efforts to minimise nuisances caused by noxious trades forms the

74. D.T. 27 November 1888.

75. Ibid 22 February 1890 .

76. Ibid 27 November 1888 .

77. Ibid 1 June 1886.

78. Public Health Act 1889. 
subject of the rest of this section. The case of Ditcham's Bone Mill is a good starting point. In 1886 Ditcham heeded the Corporation's notice to abate the nuisance arising from his business but it was not long before it started again. Despite continual grumbling by residents the Corporation was reluctant to force its closure. By October 1888 residents near the Bone Mill could take no more and in the Launceston Police Court Ditcham was forced to defend the way his trade was carried out. ${ }^{79}$ Residents stressed the danger to health: when the wind blew "in a certain direction", they claimed, it resulted in "nausea and a distaste for food and prevented sleep". 80 The defence presented medical testimony which indicated that the business was not a threat to health. Not surprisingly the manager of the Bone Mill said that his health was not affected by working there and the owner Ditcham senior added that when he was unwell or had a headache "a few whiffs of the ammoniacal deodoriser was an infallible cure". The action was brought under section four of the Launceston Offensive Trade Act 1874, which was not repealed by the Public Health Act. This clause prevented a noxious trade from being carried on within 40 feet of a public street. Thus the health implications were largely irrelevant: only a legal nuisance had to be proved. Ditcham was found guilty and ordered to pay court costs of £l 11s. 6d. and $7 \mathrm{~s}$. 6d. for every day the offence continued in contravention of the Act. 81

79. Ex. 20 October 1888. For a helpful article on the legal issues involved in nuisance cases see J.P.S. McLaren, "Nuisance Law and the Industrial Revolution - Some Lessons from Social History", Oxford Journal of Legal Studies, v. 3, No. 2., 1983, p.155-221.

80. Ex. 23 October 1888 .

81. Ibid 26 October 1888 . 
The Corporation refused to allow Ditcham to construct new buildings or to remove existing buildings outside the 40 feet limit and also were reluctant to close down the business because compensation would have to be paid. ${ }^{82}$ In December 1890 property holders and nearby residents brought another case against 'Ditcham, under section 236 of the Police Act $1865 .^{83}$ Again evidence was given that the Bone Mill affected the health of residents and John Bushman added that "the smell would interfere decidedly with the comforts and convenience of the neighbours in the vicinity". Ditcham's lawyer, Byron Miller said that Ditcham had done all he could to minimise the nuisance and remarked that

It was perfectly clear that the proceedings had been instituted by two land-grabbers who, being sharp speculators had bought the land cheap, owing to the neighbourhood of the mill, and now were moving Heaven and earth to get it moved so as to get a high price for their speculation, and out of no feeling of philanthropy towards the people in the neighbourhood.

This was a good point, cogently made and was true of many cases involving noxious trades, but Ditcham lost the case and was forced to close his business. ${ }^{84}$ Ditcham sought compensation from the Launceston Corporation, arguing that its failure to proclaim a noxious trades area was responsible for his financial 1oss. After seeking the opinion of the City Solicitor aldermen decided that compensation was not warranted. 85 Ditcham refused

82. Ibid 18 December 1888.

83. Ibid 31 December1890; D.T. 31 December 1890.

84. Ex. 14January 1891.

85. Ibid 10 February 1891. 
to give in and appealed to the Government. The Attorney-General A.I. Clark was sympathetic and was prepared to put $£ 1000$ on the estimates as compensation if the Corporation contributed $£ 500.86$ The Corporation opposed the proposal and Clark countered by introducing a Bill to allow Ditcham to carry on his business until he received compensation. 87 A public meeting protested loudly against the Bill. 88

Faced with pressure from the Government and ratepayers, aldermen began to realise that to resolve the impasse compensation would have to be paid. ${ }^{89}$ After long negotiations with the Government, the Launceston Corporation finally agreed to pay $£ 500.90$ Payment of compensation placed the Corporation in a dangerous position. The law relating to noxious trades enabled residents to elude appeal to the Corporation to stop nuisances: they could appeal directly to a Court, where their chance of success was high. Unless the Corporation proclaimed a noxious trades area, owners who were forced to close, following Ditcham's example, would seek compensation, which the Corporation would find difficult to pay. Launceston would also lose much needed industries and the economy of the city would be weakened. It was a scenario to be avoided.

The Corporation was aware of the implications but the proclamation of noxious trades area proved more difficult than it appeared. Finding a site brought the Corporation into conflict with other interests. In 1889 a number of sites were considered. The Daily Telegraph thought that Exeter, fronting on the Tamar,
86. Ibid 1 September 1891.
87. D.T. 25 September, 23 October 1891.
88. Ex. 24 October 1891.
89. Ibid 27 October 1891.
90. Hobart Gazette, 14 February 1893, p.370. 
near Swan Point was ideal but, being 20 miles down river from Launceston, the long distance from the city ruled it out. 91 As "Protectionist", writing to the Examiner, argued "the first consideration affecting .... [noxious trade] industries is to locate then where they are accessible to labour .... Any prescribed area for manufacturing sites must be within reach of a centre of population, so that employees can live at home...."92 Workers did not like travelling long distances to work. The Corporation would not consent to sites like Exeter because a town would probably grow up around the noxious trades area; population would be lost to the city and not attracted, as the Corporation aimed to do. Aldermen considered a site near the Rifle Range, much closer to the city than Exeter, but ratepayers and property owners petitioned against it because "it is too near the city, and the vitiated atmosphere arising therefrom must blow over and affect to a very considerable extent all thoseresiding in the east, which up to the present time has always been considered the healthiest part of Launceston".93 Thus aldermen discarded the site.

In 1890 aldermen enlisted the help of Alfred Mault to select a site for a noxious trades area "at a convenient distance from the city with good railway and road communications". 94 A site near Mowbray was selected. Surveys were completed: arrangements for the acquisition of land, laying on water from the Launceston Waterworks and a proper drainage system were in progress when petitions were presented to Parliament against the site. Petıtions came from the Tasmanian Turf Club, as the proposed area was near

91. D.T. 3 September 1889.

92. Ex. 21 September 1889.

93. Ibid 17, 18 September 1889.

94. T.P.P. $1891 / 70$. 
the Mowbray racecourse; from landowners, who wanted to sell their land in lots for the erection of "suburban residences"; and residents of Mowbray. 95 Work on the site was suspended. Disputes would continually arise, predicted the Central Board of Health, because the prerequisites for a noxious trades area of easy access, ample water supply and good drainage were also attractive to people desiring a pleasant area in which to live. Further consultation in 1890 resulted in a plan, suggested by the Launceston Corporation, to divide noxious trades into two categories. 96 One category, which included boiling-down works, manure works, fellmongeries, glue factories and piggeries were to be immediately excluded from towns. The other trades could stay in towns because they created less of a nuisance and appliances could be used to minimise nuisances even further. Thus compensation cases would be less likely to occur. The Central Board of Health approved of the plan but it was not implemented.

The conflict of competing interests that was characteristic of the urban environment demanded that groups organize to withstand intrusions by opponents. In May 1891 manufacturers responded to the buffeting they had received by establishing the Launceston Association of Trade and Manufacturers. ${ }^{97}$ The Association aimed to protect and advance "the general interest of manufacturing and kindred industries", to seek amendment to existing legislation that was "unnecessary, vexatious, or repressive" and to monitor proposed legislation. 98 An immediate objective was to ensure

$$
\begin{aligned}
& \text { 95. Ibid } 1890 / 152,-147, .153 . \\
& \text { 96. Ibid } 1891 / 70 . \\
& \text { 97. Ex. } 3 \text { July 1891. } \\
& \text { 98. Ibid } 30 \text { June, } 3 \text { July } 1891 .
\end{aligned}
$$


that by-laws were framed "so that manufacturing and other industries may be carried on under clearly defined conditions" in the hope that manufacturers would be protected "against capricious and unwarranted interference with the ordinary conduct of industry". A noxious trades area would also afford such protection but even with pressure from the Association one was not proclaimed. The future of noxious trades seemed uncertain. Every time an application was made to begin business there was, wrote the Examiner, "an outcry immediately. The machinery of law is set in motion, and every possible obstacle thrown in the way". 99 The Exmainer succinctly explained why:

It is not so much whether a trade is really unhealthy as that it is unpleasant, and those who hold property in the vicinity of these manufactories rightly affirm that its value is lowered by their presence .... It is useless for the health authorities to contend that they are perfectly harmless and innocuous, for all the demonstrating in the world, from a scientific point of view, will not reconcile those who have to live close by the infliction.

Aldermen gradually evolved a policy that did not sanction "the permanent establishment of offensive trades in the city" but at the same time did not curtail "the scope of industrial enterprise". 100 Applicants were asked to guarantee that business would be "inoffensively conducted", to stop business when directed by the Corporation without claiming compensation and to move to

99. Ibid 27 March 1896.

100. Ibid 31 March 1896. 
a noxious trades area when one was set up. Not all businessmen were prepared to accept these conditions, noted the Daily Telegraph, and only the long term security of tenure, made possible by a noxious trades area, would attract new trades. ${ }^{101}$ The Corporation implemented Its policy with "a wise discretion" but, the Daily Telegraph argued in 1899, it was "a debateable question whether in some cases the members do not err on the side of caution". 102 With the approach of federation, it stressed, Launceston's "great potential" as a centre of industry should be publicized and all obstacles to industrial development removed.

After federation further sites were considered, but, despite countless complaints, no noxious trades area was proclaimed. The inability of the Launceston Corporation, and other local bodies to establish a noxious trades area compelled the intervention of the Government, almost certainly at Elkington's request. The Noxious Trades Bill 1907 attempted to repeal existing legislation which enabled local bodies to prevent the Government from declaring a noxious trade area on Crown Land. 103 In effect it would give the Chief Health Officer the power to proclaim a noxious trades area wherever he liked. The Bill passed the House of Assembly but met with a frosty reception in the Legislative Council. On a motion by Peter McCrackan, who was opposed to enlarging the powers of the Corporation's old adversary, seconded by Charles Russen, both Launceston aldermen, the Bill was defeated. 104 The Government then tried to include a clause, giving it similar

101. D.T. 31 March 1896.

102. Ibid 20 July 1899.

103. M. 27 September, 16, 23 October 1907.

104. Ibid 1 November 1907. 
powers, in the Crown Lands Bill but the Legislative Council succeeded in having it struck out. 105 Anticipating another attempt by the Government to secure these powers in 1908, the Launceston Corporation made a serious effort to find a suitable noxious trades site. In March 1908 a report of the Public Works committee strongly recommended Dilston, a site about nine miles from Launceston. 106 Aldermen inspected Dilston and other sites but were unable to reach a consensus. 107

In July 1908 Alfred Wadsworth, sanitary inspector to the Department of Public Health, reacted to the various complaints he had received by bringing charges against Parsonage's boiling down works. 108 This was one of the first uses of the Public Health Act 1903: the Police Magistrate decided against Parsonage. No penalty was enforced and was not pressed for by the Department of Health, as the Police Magistrate wanted to give Parsonage an opportunity to negotiate a solution with the Council to overcome the smells arising from his business. With the spectre of compensation cases looming, the Council responded with yet another report, prepared by Thompson and David. ${ }^{109}$ This was the most complete and practical report yet produced. Three essential criteria for a noxious trades area were listed: easy and convenient access by road, good and abundant water supply and good drainage. Desirable qualities included access by water or rail, capability of being connected with city gas or electric supplies for power and light and being near the residences of workers, "otherwise population will be lost to the clty, and a township

105. Ibid 9 November 1907.

106. Ex. 4, 24 March, 1908.

107. Ibid 5, 2, 13 May 1908.

108. Ibid 14, 15, 20 July 1908; T.P.P. 1908/41.

109. Ex. 11 August 1908. 
will be formed at the site". Thompson and David rejected the sites considered by the aldermen, Rocher's Lane, Danbury Park, Cormiston and Dilston and ended the report by saying that We do not see any site which combines so many advantages as a portion of the Inveresk flats, near the Tea Tree bend; this would be near the city, yet isolated; the distance from the railway would be an ordinary cartage run; drainage could be easily installed; water supply, and electric light and gas could with ease be laid on and there is a river frontage.

Odours would not be a worry. Another site with similar advantages was at Glen Dhu.

Aldermen remained paralysed. The Examiner claimed that they were "too susceptible to local influences. They are dragged this way or pushed that way by the clashing interests of the burgesses and there is hardly a move which they can take without giving offence. If they grant a permit to anyone to start a noxious trade in the city, there is a section up in arms at once; if they refuse they are charged with obstructing the establishment of industries". 110 The only solution was to place the choice of site in the hands of the Chief Health Officer, who was free from these local influences. The Examiner also thought that the citizens of Launceston were too fastidious because in populous centres, such as London, offensive trades were widely conducted, after precautions were taken to minimise nuisances. This "minimum is borne for the sake of the advantages which the industries bring".

110. Ibid 25 August 1908. 
On 28 August 1908 the Launceston Chamber of Manufactures wrote to Premier Evans urging the Government to proclaim a noxious trades area because of the Corporation's demonstrated inability to do so. 111 Evans replied that the Government could only move on the advice of the Chief Health Officer "and in this particular case Dr. Elkington is not prepared to recommend State action". This was a curious excuse. It was uncharacteristic of Elkington not to support Government intervention. The Government itself must have feared the political implications of a unilateral decision. In September, in a conciliatory gesture, a committee of the whole Council agreed to consider any site outside the city boundary that the Government or Chief Health Officer felt was suitable. 112 Thus the Government and the Corporation could share the blame of an unpopular decision. Discussions were held with Elkington and subsequent Chief Health Officers, Doctors J.S. Purdy and S.A. McClintock, but without success. In his annual report of 1913-14 McClintock wrote that he could "see no prospect-of the subject [of a noxious trades area] being advanced any further than it did years ago", leaving Launceston "without what is an absolute necessity in any progressive municipal area where the health and comfort of the residents should be the first consideration". 113 OnIy eight noxious trades existed in Launceston; with a noxious trades area there would have been more. ${ }^{114}$ Property interests and residents had triumphed over the economic progress of the city.

c) Cemeteries

Cemeteries, like noxious trades, illustrated the connection between health concerns and townsite consciousness. The deteriorating state of neglected church cemeteries also threatened

111. C.S.D. $143 / 1 / 108$.

112. Ex. 8 September 1908.

113. T.P.P. 1914/22.

114. Ibid; in 1886 there were nine noxious trades T.P.P. 1887/78. 
the convenience and comfort of city residents as house building near them increased. Cemeteries were not just offensive: the disease creating potential of the putrefying body of a typhoid patient placed in a cemetery with defective drainage scared many people. This danger meant that public support for closing cemeteries was greater than for noxious trades. Attempts to close cemeteries brought the Corporation into conflict, not with economic interests, but religious interests as clergy opposed the Corporation tampering with the sanctity of graves. Relatives of the dead viewed graves as the last link with lost ones and their preservation was a psychologically important part of the "grief therapy" of "the Victorian celebration of death". 115

In November 1883, at the request of the Launceston Corporation, a Cemetery Commission was appointed by the Government to consider the closure of all private cemeteries and the establishment of a public cemetery on the outskirts of the city. ${ }^{116}$ In October 1884 a Bill was introduced into the House of Assembly giving the Governor-in-Council power to close existing cemeteries within three months of the establishment of a new public cemetery. However representations "by different religious bodies in Launceston" forced its withdrawa1. ${ }^{117}$ It was also suggested that the Government was reluctant to bear the cost of a new burial ground and the matter remained in limbo. 118

115. For a discussion of the Victorian and later pre-occupation with death see D. Cannadine, "War and Death, Grief and Mourning in Modern Britain" in J. Whaley (ed.), Mirrors of Mortality: Studies in the Social History of Death, (London, 1981), p.187ff.

116. Ex. 19 June, 24 July 1883; D.T. 14 November 1883.

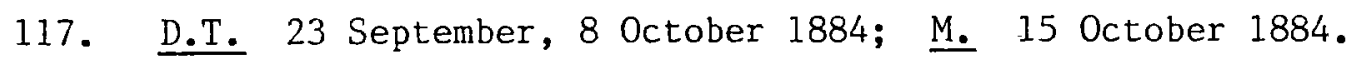
118. Ex. 17 April 1888. 
In July 1888 W.A. Wathen moved unsuccessfully to revive the cemetery question. 119 Responding to the wishes of residents near various cemeteries, in May 1889 the Corporation's Health committee recommended that all cemeteries in the city be closed, that a general public cemetery be established outside the city boundary, and that the approval of the Government to the proposals be sought. 120 The Government agreed to consider the matter if the Council "could suggest a suitable available site at a reasonable price". 121 The Examiner gave convincing reasons for the closure of cemeteries:

With the increase of population and recognising the fact that around our burial places dwellinghouses are becoming numerous their closing should not be long delayed. The sanitary interests of the city demand that a necropolis should be found away from the centre of population. 122

Sites at Mowbray and Kings Meadows were submitted to the Government, with a request that 100 acres of land be purchased. ${ }^{123}$ The Chief Secretary Philip Fysh replied that the cost of such a site would be at least $£ 5,000$ and the Government could not recommend to Parliament that such a large sum be granted, but he would meet the Mayor to discuss other sites and "if possible, utilising Government land on the Scottsdale line". 124 He added that closure

119. Ibid 10 July 1888.

120. Ibid 28 May 1889.

121. Ibid 9 July 1889.

122. Ibid 3 September 1889.

123. Ibid.

124. Ibid 29 October 1889. 
of existing burial grounds would require legislative enactment. Despite protests from private cemetery interests, the Public Health Amendment Bill 1889 was passed and gave Local Boards of Health the power to order the closure of cemeteries within six months if they were considered to be prejudicial to health. ${ }^{125}$

Negotiations with the Government dragged on until 1892 when the Launceston Corporation was offered Crown land at Carr Villa, about three miles from the city. ${ }^{126}$ The Corporation was disinclined to accept the offer, considering the site to be too far away and not near a railway line, thereby increasing the cost of burials. Aldermen gave little attention to cemeteries until 1896 when the public became more insistent. In July 1896 a writer with the initials "J.T.", the same Initials as the Health Officer Dr. Wilson, described the conditions of Launceston cemeteries for the Tasmanian Democrat. As the cemeteries were conveniently pitched on the sides of $\ldots$... hills in porous grounds, and contiguous to excavations for roads, streets and building sites, they have been aptly termed death-traps. The danger to the health of persons compelled by force of circumstances to dwell in the vicinity of those deathtraps is possibly greater than the general public dreams of. 127

J.T. advocated cremation and quoted various authorities in favour of it. In September 1896 pressure from citizens forced the Corporation to accept the Carr Villa site, comprisıng 150 acres:

125. T.P.P. 1889/page 293.

126. Ex. 21 June 1892.

127. T.D. 24,31 July, 7 August 1896. 
in January 1897 aldermen became trustees of the proposed public cemetery at Carr Villa. ${ }^{128}$ By 1899, however, work had not begun to transform the bushland into a cemetery. According to the Daily Telegraph the reason was the laxity of aldermen: no public resistance to the closure of existing cemeteries was exhibited and Carr Villa was "a highly suitable site". 129 In May 1899 a Corporation report reaffirmed its suitability. ${ }^{130}$ Finally in 1902 the Launceston Cemetery Act removed any obstacles in the way of the Corporation establishing a public cemetery at Carr Villa and the Government was persuaded to contribute $£ 3,000$ for public works on the site. ${ }^{131}$ On 1 August 1905 Carr Villa was officially opened for interments. 132 From 31 December 1905 the dead could only be buried at Carr Villa and not in the old burial-grounds: the exceptions were that, for the next 20 years, those people with immediate relatives buried in the private cemeteries were allowed to be buried in them. Thus the Launceston Corporation added the management of the cemetery to the list of functions it had acquired. By 1914 the Carr Villa cemetery had been "picturesquely" landscaped, with 30 acres being "prepared for use". 133 It provided a direct contrast to the ugly, insanitary private cemeteries. Instead of defacing the urban environment, Carr Villa enhanced its beauty, showing again how sanitary reform presaged town planning. 134

\footnotetext{
128. T.P.P. 1896/page 57; Ex. 1 September, 27 October 1896, 12 January 1897.

129. D.T. 22 March 1899.

130. Ibid 30 May 1899.

131. Ex. 13 August 1902, 28 March, 11 April 1905.

132. Ibid 2 August 1905.

133. City of Launceston Tasmania 1915, (Launceston, 1915), p.63.

134. This theme has been pursued by T. Bender, "The 'Rural' Cemetery Movement: Urban Travail and the Appeal of Nature", The New England Quarterly, v.47, 1974, p.196-211.
} 
The establishment of a public cemetery was a welcome reform but some Launcestonians wanted to go further and abolish, or at least limit, the use of cemeteries, regarding cremation as a much safer alternative. In 1912 a number of enthusiasts formed the Cremation Society of Tasmania so that "cleanliness, purity and sweetness may be associated with the sadness but grandeur of death". 135 In July 1912 a deputation from the Cremation Society, led by Dr. G.H. Hogg, waited on the Mayor to ask the Corporation to build a crematorium. 136 Hogg regarded cremation as essentially "a health question" and was "the best way for the disposal of the dead": he pointed to the popularity of cremation in Germany and England. The Reverend S.J. Baker thought that "A certain amount of noxious gases arose from a cemetery and this was detrimental to good health". The Corporation was asked to set aside part of the Carr Villa cemetery for a crematorium. In October 1912 aldermen agreed that half an acre of land "be reserved, conditional on those interested erecting a crematorium to the satisfaction of the Council within two years from January I next". ${ }^{137}$ By April 1913 Hogg bemoaned "the lack of interest on the part of the general public in the important subject of burial reform" and the chances of raising money to build a crematorium were slim. ${ }^{138}$ A crematorium was not built at Carr Villa until 1939. ${ }^{139}$

135. D.T. 13 January 1912 a letter by A.F. Purdy and an article by him D.T. 4 March 1912.

136. Ex. 25 July 1912.

137. Ibid 29 October 1912.

138. D.T. 4 April 1913.

139. A. Gellie, The Story of Launceston and its Surrounding Districts in Tasmania, (Launceston, 1952), p.97 
The emergence of the 'Dark Satanic Mills', the large unventilated factories packed with workers, employed for long hours with inadequate pay, was one of the less desirable products of England's rapid industrialization in the nineteenth century. ${ }^{140}$ The effect on the health of workers must have been devastating. Industrialization on a large scale was not an important element in nineteenth century Australian economic development. ${ }^{141}$ Various Acts were passed to regulate working conditions and included clauses on the sanitary and safety conditions of workers in all kinds of occupations. 142 Factory legislation in Tasmania was less comprehensive than in the other colonies and smaller scale industries were established. ${ }^{143}$ Sma11 industries was one reason for "the backwardness of Tasmanian unionism" and generated no "clear lines of division between workers and bosses". 144

In Tasmania inspection of factories was carried out, mainly by the police, under the Women and Children's Employment Act 1884. In Launceston Bushman also made periodic visits. In February 1888, for example, he reported that he had inspected 26 workshops

140. E.J. Hobsbawn, Labouring Men: Studies in the History of Labour, (London, 1968), Chapter 6; A.S. Wohl, Endangered Lives: Public Health in Victorian Britain, (London, 1983), Chapter 10.

141. N.G. Butlin, Investment in Australian Economic Development 1861-1900, (Canberra, 1976); R.V. Jackson, Australian Economic Development in the Nineteenth Century, (Canberra, 1977).

142. T.A. Coghlan, Labour and Industry in Australia, (South Melbourne, 1969), v.4, p.2087.

143. V.P.P. 1902-3/30 Findings of a Royal Commission on Victorian Shops and Factories.

144. R.P. Davis, "Tasmania" in D. Murphy (ed.), Labor in Politics: The State Labor Parties in Australia 1880-1920, (St. Lucia, 1975), P.392. 
and factories and found no case where the Women and Children's Employment Act was "contravened appertaining to the sanitary department". 145 It was not long before allegations of sweating were made. In December 1890 the Daily Telegraph wrote that women were working long hours in factories but the Corporation did nothing because they were "only women .... - they have no votes; they are political non-entities; and consequently find no hustings champions at either State or Municipal elections". 146 In January 1891 this changed when a deputation from the Launceston Municipal and Political Reform Association waited on the Mayor, claiming that women were forced to work 12 to 13 hours each day by "unscrupulous employers". ${ }^{147} \mathrm{~J}$. Piper said he knew of young girls working "long hours in badly ventilated rooms .... the health and wellbeing of these girls should be looked to or they would reap a sorry harvest in the future". The Daily Telegraph thought the allegations were true and they proved "the absurdity of expecting a locallygoverned police to carry out social laws". On 13 January Alderman Panton moved that the Police committee report on "the means that have been taken to carry out during the last twelve month" the provisions of the Women and Children Employment Act, what improvements to working conditions have been made and to what extent sweating existed in Launceston. ${ }^{148}$ Panton believed that ventilation was insufficient, seating was limited and the provision of water closets was inadequate. His motion was unanimously carried.

145. Ex. 21 February 1888.

146. D.T. 25 December 1890.

147. Ex. 13 January 1891.

148. Ibid 14 January 1891. 
In June the Police committee report was completed. ${ }^{149}$

25 people connected with workrooms "ranging from principals down to girls who have only been employed for a few months as beginners" were interviewed. The report concluded that sweating was not widespread in Launceston. Bushman spoke "very favourably as to the health conditions" of factories and proprietors were willing "to effect any improvements suggested by him". The Examiner also thought that sweating was not common; women did work long hours but were paid overtime. ${ }^{150}$ It was more disturbed that young girls walked "to their homes without proper escort at ten or eleven o'clock at night" as this moral danger was "the real injury of overtime". The Daily Telegraph contested the findings. It had "definite information" of sweating, particularly in the tailoring and boot trades. 151 It hoped that in the future "the question of female labour" would receive more attention from the Corporation, which would "carry out in its entirety the provisions of the Factory Act". "Parent", writing to the Daily Telegraph, also claimed that the report was not a true reflection of working conditions in Launceston. 152

In July, as a result of the agitation in Launceston, a Bill to amend the Women and Children Employment Act was introduced into the House of Assembly to replace police inspection of factories with special inspectors. The Bill was defeated but police in Launceston began to give more attention to factories. In October 1891 the Superintendent of Police reported on the amount of cubic

149. Ibid 23 June 1891.

150. Ibid.

151. D.T. 23 June 1891.

152. Ibid 2 July 1891. 
feet of air available to workers. ${ }^{153}$ Aldermen discussed what the minimum should be but could not agree on a standard. In November it was decided to ask the Chief Secretary to issue regulations defining the minimum cubic area of air to be allowed each worker and providing that "in each workroom the arrangements for ventilation and sanitation shall be such as the Board of Health may deem necessary and require". 154 Bushman inspected 35 factories and workrooms and thought that 350 cubic feet per worker was adequate, with 300 cubic feet as a minimum in the daytime and an extra 100 cubic feet necessary at night. 155 After further consultation with the Central Board of Health by-law eight was drawn up. It adopted Bushman's recommendations defining the cubic feet for each worker and ensured that factories were ventilated and heated "to the satisfaction of the Local Board of Health". ${ }^{156}$ Failure to adhere to the by-law would result in a penalty of $£ 10$ and $£ 5$ for each day the breach continued.

- Under closer supervision working conditions in factories steadily improved. Since February 1891, wrote Bushman in June' 1894, improvements had been made "from time to time" in drainage, plumbing, ventilation, rooms unfit for use were closed and work areas were 1imewashed. 157 Even the Tasmanian Democrat, the defender of the workers, praised the work of the Health department. In August 1896, in a series of articles on sweating in the clothing, building and tailoring trades, the Tasmanian Democrat referred to a clothing factory with a galvanised iron-roof, which transformed the factory into "an oven" in summer and "an ice-chest"

\footnotetext{
153. Ex. 27 October 1891 .

154. Ibid 11,24 November 1891.

155. Ibid 8 December 1891.

156. Ibid 8, 22 August 1893; Hobart Gazette, 28 November 1893,p.2361. 157. Ex. 12 June 1894.
} 
in winter, "But, thanks to the persistence of the Sanitary Department, this defect was remedied some time ago ...."158 Although factory conditions were improving, sweating was still a problem. Referring to the clothing trade, the Tasmanian Democrat estimated that "an average work-woman, one who has four or flve years at the trade, cannot earn, even with constant employment, more than sixteen shillings per week". As "constant employment" was not always available the average weekly wage, taken over a year, was more like 7s. 6d. The cost of board and lodging was "at least fifteen shillings weekly" and to survive women were often compelled to live with relatives or friends. To earn a decent wage women often took work home, which had repercussions for health because work could be done "in ill-ventilated lodgings, perhaps at the bedside of a brother or sister tossing in the agonies of a malignant fever", leaving the clothing "saturated with the germs of a contagious disease". This vivid, but overstated, example was one way of spreading disease that sanitary authorities would find difficult to detect.

After 1896 allegations of sweating and poor working conditions became less frequent. In 1902 Launceston witnesses to the Victorian Royal Commission on Factories, members of which had visited Tasmania, thought the Women and Children's Employment Act was administered judiciously, although inspections were not made very often. 159 Inspection once a year was deemed adequate by the Launceston Corporation as employers observed sanitary requirements. ${ }^{160}$ When Thompson became Health Officer he visited 49 factories and found conditions to be satisfactory in most cases. ${ }^{161}$

158. T... 21 August 1896.

159. V.P.P. 1902-3/31.

160. Ex. 30 August 1904; D.T. 13 September 1904.

161. Ex. 28 March 1905. 
In 1906, as we will see, James Long, Labor member for Lyell in the House of Assembly, made serious allegations of widespread sweating in Hobart and moved that an enquiry be held into the working conditions and wages of workers. ${ }^{162}$ Charles Howroyd, Labor member for North Launceston, told the Assembly that "From what he knew the sweating in Launceston was not nearl'y as bad as Mr. Long has made out that it was in Hobart", with the exception of "young girls engaged in draper's shops" but he supported an enquiry. A Royal Commission was appointed and in 1907 the report was completed. 163 It attacked the low wages paid to workers but said little of sanitary conditions in factories. All evidence, including that of the Health Officers of Hobart and Launceston, was suppressed by the Government, because fundamental inequalities in the industrial system had been exposed. The findings were not accepted uncritically, however, and initiated a debate that ultimately, after a number of Bills had been defeated, resulted in the Factories Act 1910. Although much of the debate centred on Hobart, it also had relevance for Launceston. The Examiner, for instance, argued that the Royal Commission had generalised "from extreme cases", thereby weakening its recommendations, but the essential point that change was needed could not be faulted. 164 The report showed, thought the Examiner, that local authorities were unable to enforce industrial legislation. Inspection of factories was "perfunctory and resolves itself principally into an odd visit now and then by a health officer". The Examiner regarded Tasmanian employers "as humane and considerate as the

162. M. 21 July 1906.

163. T.P.P. $1907 / 1$.

164. Ex. 29 July 1908. 
average, still they at times needed a little pressure to make them fully realise their responsibilities". Encapsulating the general view, the Examiner believed that it was

to the interest of the community that labour shall be carried on in healthy surroundings, that there should be proper accommodation for workers, that the lavatories should be clean and well kept, that hours of labour should not be excessive, and that where there is machinery in use it should be protected.

Only special inspectors, free of local influence, would achieve these conditions but the Factories Act 1910, the provisions of which were, wrote the Examiner, "largely hygienic" kept factory inspection in the hands of local authorities. ${ }^{165}$ If local authorities failed to discharge their duties, the Department of Public Health could intervene. The Act came into force in March 1911 and it was not long before the Launceston Corporatıon's administration came under attack. In September Charles Howroyd asked the Premier why the provisions of the Factories Act were "not being largely observed in Launceston?": he claimed that "not one-fourth of them are carried out". 166 Howroyd wanted special factory inspectors appointed by the Government "so that the working classes in Launceston may enjoy the benefits of this Act". Premier Elliott Lewis replied that he was not aware that the provisions were not being enforced by the Launceston Corporation. The Daily Telegraph, a keen advocate of industrial reform, had heard of no "opposition to the Act, or of breaches flagrant enough to cause prosecutions". 167

165. Ibid 6 September 1910.

166. M. 13 September 1911; T.P.P. 1911/page 33.

167. D.T. 10 November 1911. For the Daily Telegraph's view of the Royal Commission see D.T. 23 July 1906, 16 May, 6 November 1907. 
AIderman Sadler defended the Corporation's factory inspector William Murnane. ${ }^{168}$ Murnane had done his best to comply with the Act but, as we saw earlier, was burdened with too many duties and Sadler wondered if another inspector should be appointed. The Mayor replied that no complaints had reached the Corporation but the Health committee was considering the appointment of a new inspector who would be a trained mechanic.

As we know another inspector was not appointed. Murnane's workload prevented him from sending factory returns to Purdy, the Chief Factory Inspector, until 5 July 1912, a delay of 16 months. 169 As if this was not enough to evoke Purdy's ire, the returns were sent to the occupiers of factories to be filled out and were not filled out by Murnane. This, wrote Purdy, "was calculated to. hold the whole matter of inspection up to ridicule". Purdy arranged with the Launceston Corporation that an inspector "directly responsible to the central Department" be appointed to inspect Launceston factories. 170 Thus partly from a lack of staff and probably also from a desire not to estrange factory owners, factory inspection by the Launceston Corporation was on balance a failure.

In important areas of public health reform, then, the Launceston Corporation tended not to enforce its legislative powers to the fullest extent, thereby benefiting certain interest groups. Thus insanitary housing was rarely ordered to be demolished, municipal housing was not provided and a noxious trades area not proclaimed mainly because of the pressure of property interests.

168. Ibid 15 November 1911.

169. T.P.P. 1912/14.

170. T.P.P. 1914/22, p.16 by June 1914206 factories were registered in Launceston. 
Factory owners were apparently influential enough to avoid frequent factory inspection. Municipal action was also limited by an understaffed Health department, inadequate legislation and economic considerations, for example in paying compensation to owners of noxious trades ordered to close. Apart from overcoming the opposition of religious interests and securing the closure of cemeteries, the Launceston Corporation appeared to place the welfare of vested interests ahead of the welfare of urban residents. 
PART 3

HOBART $1886-1914$.

"Providence had been very good to Hobart. It remained for man to do his part and they were striving to do that"

Mayor R.J. Meagher

M. 3 February 1914.

"If some future historian were writing the history of Hobart he, would truly say that for the first hundred years of its existence it was a rather slow-and-go-easy place, but when it had attained its first century of life, and cut its wisdom teeth, so to speak, it began to go ahead .... It had gone ahead in the last few years more than it had gone ahead in any other thirty years that he could remember".

Edward Mulcahy

M. 12 December 1914. 


\section{CHAPTER SIX}

\section{THE POLITICS OF SANITARY IMPROVEMENT}

The Hobart City Council, as was noted in Chapter Two, was considered to be very backward in its approach to city government. It held a narrow view of its role in the city and saw its aim as keeping the rates as low as possible. In the 1880 s this was becoming no 1onger acceptable. One reason was a resurgence of growth in the Tasmanian economy after a long period of depression. ${ }^{1}$ Improved material conditions heightened expectations of what life could offer. Economic buoyancy also influenced political thought. Liberalism challenged conservatism as the leading political attitude and people were more willing to accept political and social change. ${ }^{2}$ As the seat of Parliament and capital of the colony, Hobart was deeply affected by the ferment of reform and became "a liberal stronghold". 3 Adding to the ferment was a population drift to the towns, which was "the outstanding feature" of the $1880 s .^{4}$ The population of Hobart and suburbs increased from 23,633 in 1881 to 34,807 in 1891. (Table 12) The larger population highlighted deficiencies in civic management, placing new pressures on civic amenities, and the way in which the city was governed came under closer and prolonged scrutiny. People did not approve of what they found. Hobart had been settled for

1. H. Reynolds, "The Island Colony, Tasmania: Society and Politics 1880-1900", unpublished M.A. Thesis, University of Tasmania, 1963, p.26ff.; T.A. Coghlan, Labour and Industry in Australia, (South Melbourne, 1969), v.4, p.1819 are useful accounts of this growth which began in the 1870s.

2. Reynolds, Ibid, p.55.

3. Ibid, p.83.

4. G. Blainey, "Population Movements in Tasmania 1870-1901", T.H.R.A., v.3, 1956, p.66. 
80 years but a general feeling emerged that the potential predicted when it was first settled had not and was not being realised. A common description was that nature had done everything for Hobart but man had done nothing. This chapter will consider in detail aspects of municipal reform in Hobart, stressing the contribution made by sanitary reformers to better urban government.

TABLE 12 : ESTIMATED POPULATION OF HOBART

\begin{tabular}{|c|c|c|c|}
\hline Year & City & Suburbs & Total \\
\hline 1881 & 21,118 & 2,515 & 23,633 \\
1891 & 25,916 & 8,891 & 34,807 \\
1901 & 24,655 & 10,027 & 34,682 \\
1911 & 27,709 & 10,682 & 38,391 \\
1914 & 31,943 & 7,971 & 39,914 \\
\hline
\end{tabular}

\section{Source: Statistics of Tasmania.}

Trenchant editorials and letters to the press were the most obvious manifestations of discontent with the Hobart Corporation. It was argued that a restrictive franchise led to the election of aldermen with a myopic view of the city's future. Rates were frittered away with little public benefit: expenditure exceeded revenue and excessive borrowing to cover up financial mismanagement put the Council into debt. Sanitary neglect in the face of serious epidemics of typhoid and other infectious diseases damaged Hobart's proud reputation as the sanatorium of the Australian colonies, and drove away tourists and their much desired money. The management of the city by the Corporation was well summed up thus: "a conspicuous looseness in money matters, stolid indifference to public health, and an utter disregard of popular opinion". 5 The press became a particularly powerful weapon in 
moulding popular opinion in the 1890s, when the labour weekly the Clipper and the liberal daily the Tasmanian News were at the forefront of concentrated attacks on the Hobart Corporation. They questioned whether the composition of the Corporation reflected the interests of the city or the interests of individual aldermen and their supporters and whether men with the right background and experience stood for election. Even the conservative daily, the Mercury, which was generally less critical than the other newspapers, thought, in 1889 , that aldermen were "mostly incapable and prefer their own ends too often to the welfare of the city". 6

In the 1890s municipal reform became a catchcry. Fraser has argued that in England "municipal reform came to define its pur-pose in public health". 7 This was the case in Hobart. The view that became dominant was well expressed by The Register and Property Investor's Guide, which wrote on "all questions affecting the interests of REAL ESTATE commercially and politically". 8 It thought Hobart was far behind in sanitary matters and believed that "a really good and comprehensive sanitary system is unquestionably the most important factor in the progress and well-being of a city ...." A proper sanitary system was the issue that brought together those calling for the reform of the Corporation. Men with business expertise were required who could manage the city's finances to ensure sufficient funds were allocated towards keeping

6. M. 8 October 1889.

7. D. Fraser, Power and Authority in the Victorian City, (Oxford, 1979), p.167; H. Meller, Leisure and the Changing City 1870-1914, (London, 1976), p.237 agrees.

8. R.P.I.G. 6 September 1895.

9. Ibiud 18 August 1896. 
all parts of the city clean and free of disease. 10 Well-made streets, a proper sewerage and drainage scheme, a pure and continuous water supply, removal of refuse and enforcement of building regulations were fundamental duties that the Council neglected. Sanitary reform, however, often conflicted with the interests of property owners and the municipal franchise was designed to protect those interests, as we shall see. When this basic fact. of the source of municipal power was recognised as being at the root of inequality demands for reform and democratisation of the Council strengthened. In the words of Fraser "issues of improvement, superficially non-political, could in practice generate enormous political heat as urban society faced up to the problems of environmental control and the public provision of social utilities". ${ }^{11}$

In Chapter Two it was noted that ratepayers expected aldermen to manage economically the finances of the Council: the Launceston Corporation generally did this very well while at the same time providing a range of services for ratepayers. On the other hand the Hobart Corporation provided a limited number of services and was often criticised for being extravagant or misusing available funds. To those who demanded more money for city improvements, the Mercury pointed out in 1886 that the city was growing, resulting in "a very large quantity of work to do with a comparatively

10. T.N. 2 February 1889.

11. D. Fraser, Urban Politics in Victorian England: The Structure of Politics in Victorian Cities, (London, 1979), p.10 An American study C.V. Harris, Polıtical Power in Birmingham 1871-1921, (Knoxville, 1977), p.181 states that generally improvement policy was "non-controversial" but at times "provoked bitter hostilities". For the role of improvement policies in the development of Sydney see A. Roberts, "City Improvement in Sydney: Public Policy 1880-1900" unpublished Ph.D. Thesis, University of Sydney, 1979. 
small amount of funds". 12 This forced the Council "to neglect some things which are admitted to be required and to be content with the principle of here a little and there a little". The struggle for scarce financial resources to improve the sanitary condition of parts of the city was one reason for the emergence of Ratepayers' Associations. Economy, however, was more popular and was preached by candidates at municipal elections and, especially when the effects of the 1890s depression began to be felt, all attempts to increase rates were strenuously opposed both inside and outside the Corporation. ${ }^{13}$ The usual strategy was to retrench employees or amalgamate jobs: this resulted in substantial savings in 1892 and $1895 .^{14}$ Reducing expenditure on public works also helped the Council to balance its budget from $1896 .^{15}$ Alderman George Davies was one of the apostles of economy, riding to victory in the municipal elections of December 1889 on an economy ticket. 16 His view, which prevailed throughout the 1890 s, was that ratepayers "would put up with some inconvenience rather than have their rates increased". 17 As the economy-minded aldermen in Launceston had done, Davies criticised the use of funds accumulated by one department being spent on another. In April 1895 he said: "They had no right to use rates for other purposes than those for which they

12. $\quad$. 8 December 1886 .

13. Ibid 3, 4 July 1889 for debates on a motion by Alderman Reynolds to add a penny to the municipal, sanitary and water rates.

14. Ibid 22 November 1892; 22 January, 26 February 1895.

15. The Statistics of Tasmania show that from about 1896 credit exceeded deficit. Figures are also given in G. Knibbs, Local Government in Australia, (Melbourne, 1919), p.14-12 but his details of expenditure were "approximate only" from 1882 to 1909 .

16. M. 11 December 1889.

17. Ibid 2 April 1895. 
were levied". 18 From 1896 the auditing of Corporation accounts by the Auditor-General resulted in tighter accounting procedures. ${ }^{19}$

The call for men with proven business experience and success to stand at aldermanic elections was justifiably louder in Hobart than in Launceston. In November 1886 the Tasmanian News emphasised the importance of civic life because aldermen had "a more direct bearing upon the comfort and prosperity" of citizens than members of the House of Assembly. ${ }^{20}$ However individuals elected to the Council were "morally and intellectually unworthy of the distinction". In 1887, after a serious typhoid epidemic, it urged men with "sufficient business like qualities", who would give more attention to sanitation, to seek election. 21 In December 1886 the Mercury entreated men "with the capacity for generalisation and the business facility which lies at the root of all commercial success" to stand. 22 In the 1890s, apart from Sanitary Association candidates John Bradley, a retired public servant and businessman, and George Seabrook, a builder and contractor, elected in December 1892, the newspapers' pleas were largely ignored: only Samuel Benjamin, a wealthy, retired boot and shoe manufacturer, and George Kerr, a draper, consistently supported municipal reforms introduced by Bradley and Seabrook. After trying for over ten years, the Tasmanian News wrote in 1897 that "the very men who could confer the greatest advantages on the citizens, businessmen of know integrity and tried capabilities, absolutely refuse to take part in the management

18. Ibid.

19. Ibid 3 December 1901 Davies' view on his retirement from the Council.

20. T.N. 5 November 1886 .

21. Ibid 26 November, 1 December 1887.

22. M. 8 December 1886 . 
of municipal affairs", such was the low esteem in which the Council was held. 23

The organization of citizen's groups to vent their dissatisfaction with urban government gave impetus to municipal reform. Prior to 1885 public involvement in municipal elections was relatively slight: the major protagonists appear to have been temperance bodies and licenced victuallers. ${ }^{24}$ As financial problems became more obvious and as epidemics stimulated concern for public health the interest of other groups became more intense. Public meetings, initially called by the Trades and Labour Council, were held before municipal elections to hear the views of candidates. ${ }^{25}$ A manifestation of the growing popular concern with disease and the quality of urban life was the formation of Ratepayers' Associations in Battery Point, West Hobart and North Hobart in 1887. Each association had a chairman, an executive, a secretary and a treasurer, to whom nominal membership fees were paid: they included past and present aldermen and were used by some men as stepping stones to aldermanic seats. Members of the associations were drawn together by residence or property ownership in a particular suburb: property owners represented the demand of the associations for lower rates. For example Thomas Paton, who with his brother owned property rated at over $£ 600$ and who later became President of the Hotart and Suburban Property Owners Association, during one meeting on sanitary improvements, said he "would be very sorry to offer a handle to the corporation to levy more rates upon property" as rates were too high already. 26

\footnotetext{
23. T.N. 6 December 1897.

24. M. 12 December 1889.

25. Reynolds, op.cit.p.203-4.

26. M. 20 October 1887. Paton's property ownership was calculated from the 1891 Assessment Roll.
} 


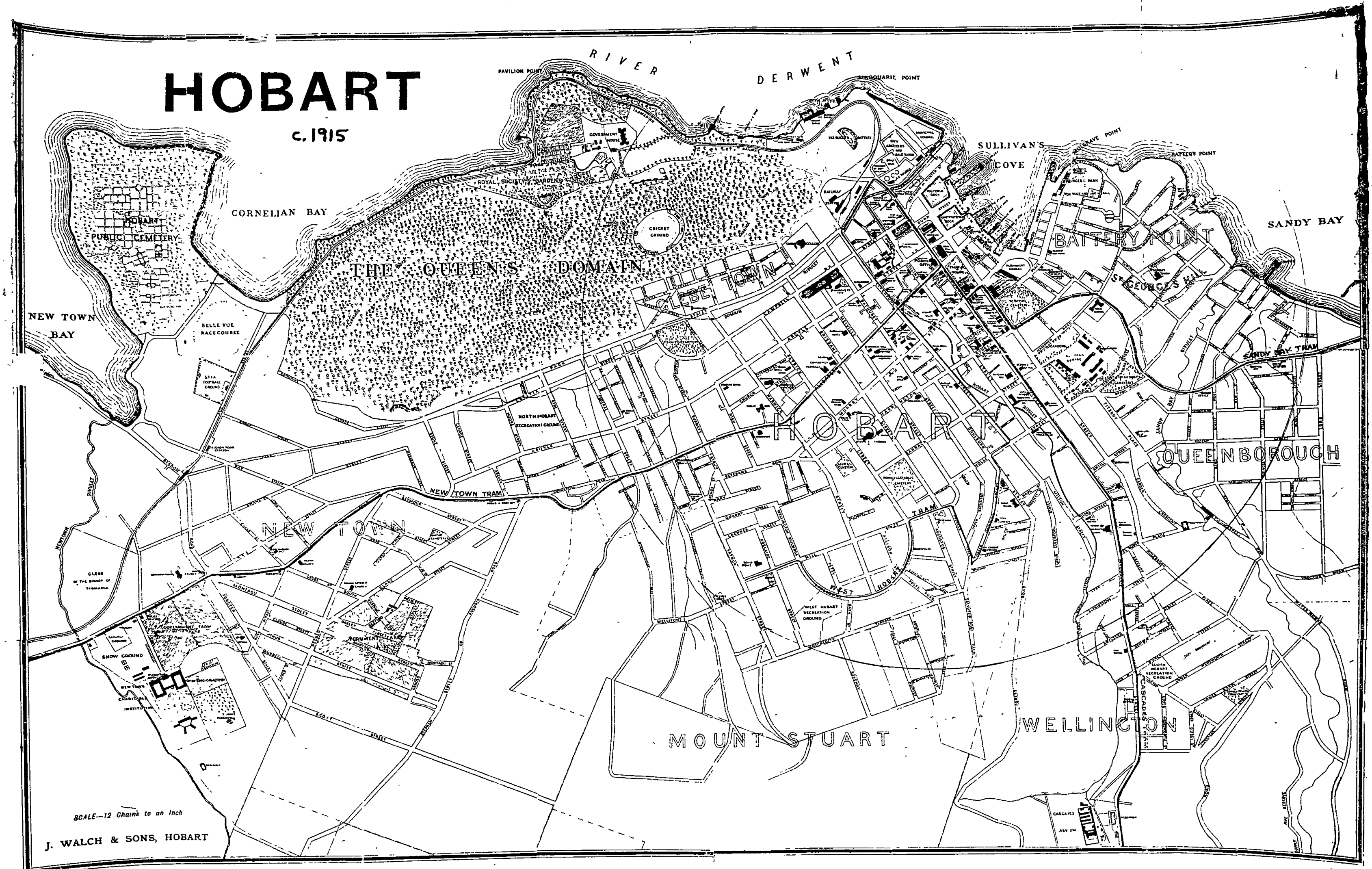


The associations sought various improvements to the local environment, including better police protection or lighting, but improved sanitation was the major objective. According to one member, H.T. Gould, writing in 1900, the associations were formed during the typhoid epidemic of early 1887 when "something like a panic was caused by the muddle into which the City Council had drifted, owing to the change from cesspit system to a pan system". 27 In October 1887 a conference of Ratepayers' Associations was held and compiled a set of questions on sanitary improvements to ask candidates at the municipal election. ${ }^{28}$ Opinions were wanted on the pan system, nightsoil disposal, refuse removal, drainage, water supply, street and gutter sweeping and the erection of public urinals. ${ }^{29}$ Interest in the associations soon waned and was only revived by annual typhoid epidemics: by 1890 only office bearers appeared at meetings and they were "merely associations in name". 30 Only the residents of West Hobart remained active after 1890 . A new body the Lansdowne Crescent Improvement Association appeared and was later subsumed by the West Hobart Sanitary and General Improvement Association, which covered the electorate of West Hobart in the House of Assemb1y. 31 In May 1897 the President of the West Hobart Sanitary Association summed up its role: it had not been "demonstrative in its actions [but] it had from time to time attended to the interests of the district". 32 In general the Ratepayers' Associations were only marginally successful. After five years of epidemics, wrote the Tasmanian News in July 1891,

27. T.N. 12 December 1900.

28. Ibid 11,20 October 1887.

29. M. 3 December 1887.

30. T.N. 28 November 1889.

31. M. 17 March 1893 for the Lansdowne Crescent Improvement Association and M. 29 August 1893, 24 January 1895 for the West Hobart Sanitary Association.

32. Ibid 20 May 1897. 
the City Council was "jogging along in old ruts indifferent to warning and, apparently, indifferent to consequences". 33

The Ratepayers' Associations were too parochial in their aims. Sanitation required a city wide perspective and found it when the Sanitary and General Improvement Association of Hobart and Suburbs was formed at a "large and representative meeting" in August 1891. 34 The convener, E.J. Rogers, a real estate agent, had wanted to form the association "for some time" but waited "for those in power to do something before he took any action". He had become "anxious" at the inertia of the Council and wanted to assist it to purify and improve the sanitary system of Hobart. Speakers outlined ways to overcome sanitary defects: the pan system received most criticism, particularly from Doctors R.S. Bright, E.J. Crouch and G.M. Butler. The Health Officer Dr. Edward Giblin was present. He said he would have become a member if he had not been employed by the Council. Instead, he entered Parliament to assist the movement for underground drainage. The Mercury thought the meeting was "a good sign" but some speakers were "needlessly alarmed, or, perhaps, excited in their desire to make out a strong case against the local authorities". 35 It placed the onus on the citizens of Hobart: if they were careful with their sanitary arrangements disease would be reduced. The Tasmanian News regarded the involvement of doctors as a "new departure" and gave the Sanitary Association a level of collective medical expertise that the Corporation could not match. 36

33. T.N. 20 July 1891.

34. M. 18 August 1891 .

35. Ibid 19 August 1891.

36: T.N. 1 September 1891. 
To assist the Sanitary Association in surmounting Corporation ineptitude, the Women's Sanitary Association was formed on 9 September 1891 when the Mayor's court-room was "overflowing" with women. 37 Lady Teresa Hamilton, wife of the Governor, was in the chair. She believed that for women it was "as health conservers that their highest calling lies. For on the good health of their mankind depends the power, the wisdom and the wealth of the nation". She blamed the Corporation for defective sanitation and the typhoid epidemics. Mrs. Maud Montgomery, wife of the Bishop of Tasmania, said that "The Angel of Death" was with them "sparing neither young nor old, rich nor poor - the young man in the full pride of his life, the fair young maiden, the little child, even the very doctors who went about striving to stem the torrent of Death - all had been his victims". She stressed personal responsibility for sanitation: "Let each keep his own doorstep clean, each attend to his own part and the village would be clean". Enily Dobson, wife of the next Premier Henry Dobson, was typıcally less charitable to the Corporation. She ferociously charged that "the loathsome sanitary conditions" of years past forced women "to protest against the inactivity and callousness which are declmating our homes and causing widespread grief and desolation". She spoke feelingly of "the voice of reproach from the graves of those lost through our apathy": al1 should unite to improve sanitation.

The two associations were equally committed to their cause, often meeting with the Council to present recommendations for

37. M. 10 September 1891. An idea of the work of the Women's Sanitary Association can be gained from A.R. Taylor, "Mrs. Henry Dobson: Victorian 'do-gooder' or Sincere Social Reformer: An Analysis of Her Charitable and Public Welfare Work in the 1890s", unpublished B.A. Hons. Thesis, University of Tasmania, 1973, Chapter 3; see also articles written by Teresa Hamilton in the Tasmanian Mail from 19 September 1891. 
sanitary reform, but they adopted different strategies. The Sanitary Association set up sub-committees to enquire into a particular aspect of sanitation, assessed how the Council carried out its duties and the threat to health and prepared a report with recommendations on how to eliminate or minimise the nuisance. Thus they based their arguments on first-hand, detailed, empirical research, in the tradition of the great sanitary reformer Edwin Chadwick. Standing sub-committees were established on street sweeping and the flushing of gutters; the Hobart, Park Street and Sandy Bay rivulets; the pan system; refuse destructors; and the burial and disposal of the dead. Temporary sub-committees were appointed to report on other nuisances as they arose. Each sub-committee usually included a doctor to give the reports professional credibility. The Tasmanian News described the reports as "reliable" guides to "the black spots of the city". 38 There was also a standing sub-committee on the conservation of beauty spots and advertising the colony's attractions: the removal of the slaughteryard, more recreation grounds, the landscaping of . old burlal grounds and planting trees and lawns in the city were among its concerns. 39 Beautification was considered to be outside the scope of the Sanitary Association's work and received less emphasis: it was taken up by the Tasmanian Tourist Association, established in 1893, which pressured the Council to do more for tourists and of which a number of sanitary and municipal reformers became members. 40

38. T.N. 16 October 1891.

39. Ibid 20 May 1892, 22 February 1893.

40. C.A. Morris, "In Pursuit of the Travelling Man: A Study of Tasmanian Tourism to 1905", unpublished B.A. Hons. Thesis, University of Tasmania, 1974. 
The emphasis on personal responsibility for health and cleanliness led members of the Women's Sanitary Association to adopt a different approach to the men. Members were allocated a street or group of streets and they visited "almost without exception, every house in the city" to give sanitary instruction to women. 41 Philip Fysh, head of the Central Board of Health, was persuaded to print cards with, on one side, 'Rules for Health', prepared by Giblin, and on the other instructions for nursing cases of infectious diseases: the cards were "widely distributed". 42 This "educational line of action", said Teresa Hamilton, was central to their work. She also gave lectures to the Y.W.C.A. on hygiene. The Mercury praised the association for its "excellent work" in teaching "women generally the importance and the practicability of sanitary reform". ${ }^{43}$ The Central Board of Health was certain that "the influence of women will be found to be the most potent means to incite the heads of households of all classes to pay proper attention to all health matters". 44 One correspondent to the Mercury claimed the role of women was unique because "Women have an innate love of cleanliness, have keen noses for unwholesome smells, have more leisure and are privileged to make house to house visitation". 45

Despite the evidence collected by the sanitary associations, aldermen remained deaf to their demands. Hence they decided to

41. M. 13 July 1892; see also S.M. Hay, "Municipal Housekeeping: The Role of Women in Improving Urban Sanitation Practices 1880-1917" in M.V. Melosi (ed.), Pollution and Reform in American Cities 1870-1930, (Austin, 1980), p.173-98.

42. M. 24 October 1891; T.P.P. 1892/41.

43. M. 23 November 1891 .

44. T.P.P. $1892 / 41$.

45. M. 20 September 1892 letter by M. Johnston. 
try direct political activity. In December 1892, as was mentioned earlier, two members, Bradley and Seabrook, contested the municipal elections. No doubt due to the publicity of the two associations, all candidates, wrote the Mercury, were "strong upon sanitary matters", which have "become popular, so that most of the candidates think that it is a good card to play ....": only Bradley and Seabrook, however, were genuine about sanitary reform. ${ }^{46}$ Bradley, Seabrook and John Duff were elected. According to the Tasmanian News, they were men of "personal respectability, intelligence and public spirit" and were "sound on the vital question of sanitation". 47 Bradley and Seabrook also received the support of the temperance party: Duff was supported by builders and butchers. ${ }^{48}$ This support and the decision of the retiring aldermen not to seek reelection secured their victory. That Bradley in particular was sincere in his efforts to achieve sanitary reform will be seen in later chapters. Bradley was the most progressive alderman of the 1890s. He was "a much-respected and esteemed citizen of Hobart", who was "ready to help [the poor] at all times" and had "a steady and unflinching hope for the ultimate betterment of this grey and sordid world". 49 The Sanitary Associations endorsed other candidates in subsequent elections but even when they were successful a majority of aldermen always seemed to be against reform. Some candidates simply espoused the views of the two associations to win votes: as the Tasmanian News wrote, "a hardening process sets in as soon as a candidate for municipal honours secures a seat" and no reform was tried. 50

\footnotetext{
46. Ibid 7 December 1892.

47. T.N. 9 December 1892.

48. M. 8, 9 December 1892.

49. Ibid 15 November 1900; Cl. 17 November 1900.

50. T.N. 23 October 1893.
} 
The Sanitary and General Improvement Association was fairly active from 1891 to 1896. No membership lists survive but 68 members were confirmed from newspaper reports. The professional middle class were the leading members and kept the association alive. In May 1897 the Tasmanian News wrote that nothing had been heard of the association for some months. ${ }^{51}$ It had apparently disbanded because members had "grown weary in the almost hopeless fight against official indolence and stagnation". In April 1900 the association made a transitory reappearance when bubonic plague became a potential threat to health. 52 It folded up in late 1900 and members concentrated solely on political involvement, as we will see. The Women's Sanitary Association also became less active after 1897, reappearing in about 1901 as the Women's Health Association and was still in existence in 1914. Sanitary education remained important and to it were added a wider range of concerns, including improved conditions for women factory workers, better housing for the poor and, above all, the health of children. Although attacked for being "extremists" and "hysterical shriekers", the members of the Men's and Women's Sanitary Associations held on doggedly to their ideals. 53 Success in prartical terms was negligible. They did succeed, however, in making sanitation a major issue in municipal life, forced aldermen "to take cognisance of evils and nuisances which had been permitted to exist without any attempt at removal for years" and alerted the public to the need for domestic cleanliness. 54 The 1890 s

51. Ibid 19 May 1897.

52. M. 10 April 1900.

53. George Davies attacked "the talk of the few extremists on sanitary matters who were dangerous to the community". M. 28 February 1896. The term "hysterical shriekers" was used by J.B. Walker, see P. Benson Walker, (ed.) Prelude to Federation (1884-1898): Extracts from the Journal of James Backhouse Walker, (Hobart, 1976), p.135.

54. T.N. 19 May 1897. 
was thus a key decade in community awareness of public health problems and laid the foundation for success in the next decade.

The election of new aldermen with fresh ideas was one way to alter the direction of Council policies and make it more sensitive to the citizen's needs. To many reformers, however, alteration to the constitution of the Council was the only way to achieve real change. In 1893 an opportunity arose when the various acts under which the Hobart Corporation operated were to be consolidated. On 5 October a deputation from the Hobart Sanitary and General Improvement Association presented aldermen with changes they wanted, including an increase in the number of aldermen from nine to twelve and the division of the city into wards. 55 Mayor Crouch was not violently opposed to the changes, although he had reservations about the divisive effects of the ward system. He advised the deputation to hold a public meeting to gauge the views of ratepayers.

On 6 October, during debate in the House of Assembly on the Hobart Corporation Bill 1893, some members supported changes to the constitution. 56 Edward Mulcahy was the most forthright. He claimed that "the citizens of Hobart were not satisfied with the Council and wanted a different body from that they now had". The first requirement was to "infuse new blood into the Council, and so tend to move the old members out of the groove in which they seemed to have been in for so many years". The AttorneyGeneral A.I. Clark referred to the English experience of wards with aldermen and councillors to represent the citizens: such a system had provided "men of greater variety of talent and capa-

55. M. 6 October 1893.

56. Ibid 7 October 1893. 
bilities". A well-known bookseller Charles Walch had suggested to Clark that Hobart should have 12 councillors and 6 aldermen: each ward, based on the electoral divisions of the city, would elect for councillors and the councillors would elect the aldermen. 57 Debate was postponed to give aldermen a chance to consider these proposals.

On 9 October Bradley moved that a poll be taken on increasing the number of aldermen to 12, the election of the Mayor by the citizens and the ward system. 58 Alderman Johnson described the motion as "very sweeping". Aldermen were capable of electing the Mayor and the ward system had little support in Hobart, said Johnson, because it was "calculated to excite jealousies and disputes between the claims of citizens in their respective wards". He opposed the plebiscite because of the cost. Alfred Crisp, something of a populist alderman, was not necessarily in favour of the changes but he thought that the citizens should be allowed to express their views. The majority of aldermen concurred and the motion was passed. At a subsequent meeting Seabrook moved that, for the changes to be adopted, a minimum of 3,000 voters and a two-thirds majority had to be gained. 59 These conditions were very restrictive. Bradley argued for a majority for or against the measures but Seabrook's motion was passed on the casting vote of Crouch.

57. These ideas were first floated in October 1890 in a pamphlet Walch circulated written by "An English Ex-Mayor" entitled How we Managed Our Municipality, (Hobart, 1890).

58. M. 10 October 1893 .

59. Ibid 17 October 1893. 
Ratepayers enunciated their views in letters to the press as new interest in municipal affairs seemed to have at last been stimulated. On 16 October at a "crowded" public meeting the Council came under heavy attack, with Mulcahy again conspicuous. 60 To rousing cheers he charged that "A lot of money had been spent [by the Council], but it could not be said that the pavements, roads or waterworks .... were what they should be, or that the Building Act had been properly carried out ....". Three more aldermen and the ward system, he went on, would result in "an increase of numbers, ideas and ability on the Council". The poll was held on 20 October. The press were unanimous that it was a "fiasco". 61 Despite wide publicity only 653 ratepayers voted. The vote was overwhelmingly for an increase in aldermen and, to a lesser extent, for the election of the Mayor by the citizens: the ward system was easily defeated. The poll proved, wrote the Mercury, that there was not "an effective spirit of reform in the community, such a spirit as would cause municipal matters to come right under almost any constitution". 62 No attempt was made to include any of the proposals in the Hobart Corporation Act 1893 and the ward system was not raised again before 1900. The most important new provision was to grant the vote to female ratepayers on the same scale as men: this gave eligible members of the Women's Sanitary Association more leverage at municipal elections, but women remained ineligible for an aldermanic seat up to 1915. As was indicated earlier the municipal franchise was considered by most reformers to be the greatest obstacle to change.

60. Ibid.

61. Ibid 21 October 1893; T.N. 23 October 1893. 62. M. 23 October 1893. 
TABLE 13 : SCALE OF VOTING AT HOBART MUNICIPAL ELECTIONS.

1) Hobart Town and Launceston Municipal Councils Act 1852

1 vote for an annual value of $£ 10$ and under $£ 50$

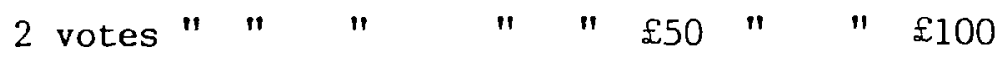

3 " " " " $£ 100 "$ " $£ 200$

4 " " " " $£ 200$ and over.

2) Hobart Town Corporation Act 1857

1 vote for an annual value of $£ 10$ and under $£ 50$

2 votes " " " " $£ 50$ " "

3 " " " " " $1100 "$ "

4 " " " " " $£ 150 "$ " $£ 200$

5 " " " " $£ 200 "$ "

6 " " " "

7 " " " " $\$ 300$ and over.

3) Hobart Town Corporation Act 1869

1 vote for an annual value of $£ 8$ and under $£ 40$

2 votes " " " " $\$ 40 " ~ " £ 80$

3 " " " " $£ 80 "$ " $£ 120$

4 " " " " $£ 120 " ~ " £ 160$

5 " " " " "£160" " $£ 200$

6 " " " " "

7 " " " " 240 and over.

4) Hobart Corporation Act 1913

1 vote for an annual value under £50

2 votes " " " of $£ 50$ and under $£ 100$

3 " " " " $£ 100 "$ "

4 " " " "£150 and over.

Source: G. Knibbs, Local Government in Australıa, (Melbourne, 1919), p.136-9. 
In Australia, whenever local government came under attack, the restrictive franchise was adduced as the reason for corruption or for the disregard of the needs of city residents in favour of property. 63 The struggle for a wider municipal franchise for Hobart was as intense as that for manhood suffrage in Parliamentary elections. As one critic put it: "every argument for a Democratic franchise in State legislation is equally applicable to Municipal Government. Government by the people for the people must hold good in National and Municipal politics ...."64 In Hobart large property owners, owning property rated at $£ 240$ and over, could have a maximum of seven votes in municipal elections. (Table 13) To become an alderman a man had to possess property to the value of $£ 500$ or be rated at an annual value of $£ 100.65$ Not unanimously acceptable when first introduced, there remained a smouldering discontent with these restrictive provisions: in the 1890s, as Iiberalism gained ascendancy, the restrictions became untenable.

In 1893, when municipal reform was in the offing, plural voting was attacked. During debate on the Hobart Corporation Bill 1893 Colonel Windle St. Hill, a member of the Progressive Liberal Association representing North Hobart in the House of Assembly, "objected" to seven votes and wanted a maximum of five. 66 On 16 October a public meeting went further and demanded one man one vote. 67 These efforts failed. In 1895, however, the House of

63. see for example A.J.C. Mayne, " 'A Most Pernicious Principle': The Local Government Franchise in Nineteenth Century Sydney", A.J.P.H., v.27, No. 2, 1981, p.160-71.

64. C1. 27 September 1902.

65. Hobart Corporation Act 1857.

66. M. 7 October 1893.

67. Ibid 17 October 1893. 
Assembly passed a motion by Mulcahy that plural voting be reduced to five for those rated at $£ 200$ and over. ${ }^{68}$ Mulcahy said he aimed for parity between single and plural voters. His motion received little opposition but was defeated in the Legislative Council. 69

These initial assaults on plural voting were mild compared with newspaper criticism. In particular the C1ipper provided a sustained critique of the political and social inequalities perpetuated by the dominance of property in the City Council made possible by the limited franchise and plural voting. 70 Every time the Council failed to adopt a progressive line of action the Clipper blamed plural voting. In 1895 it explained that "alderman is another name for property-holder or landlord". 71 Necessary work, like improving gutters in Wapping and other poor parts of the city, or improving the shocking housing of workers, was not done because the Hobart Corporation was run "in the interests of brick and mortar, which rules the roost by plurality of votes". 72 The property franchise results "in the dirt and disease and monopoly and poverty and pitiful wretchedness of what should be the prettiest and healthiest and most desirable city in Australasia". 73 The Clipper claimed that "plural voters generally reside in healthy localities and being well-fed and clothed and not overworked, their risk of disease is reduced to a minimum": workers lived in unhealthy

68. Ibid 18 September 1895.

69. Ibid 5 October 1895.

70. C1. 19 January, 6 March 1895. The Clipper had "a large circulation" and supported "the Liberals and Progressives" in Tasmanian politics. It was not yet the official labour paper but gained this reputation by espousing the cause of the working class see Cyclopedia of Tasmania, (Hobart, 1900), v.1., p.293.

71. C1. 21 September 1895.

72. Ibid 9 November 1895.

73. Ibid 3 July 1897. 
localities and being "underfed, underpaid and run-down .... feed the typhoid scourge and crowd the hospitals". 74 It held that "every man or woman who breathes the air of this city and is compelled to use its streets" had as much right to vote in municipal elections "as those who own terraces of houses and building sites": the poor were "forced to stay and work amidst possibly unhealthy surroundings while the property owners can clear out whenever they want ...."75 The crux of Hobart's sanitary plight was that "cleanliness means extra cost; dirtiness is cheap". 76 Property owners bore the cost of cleanliness through increased rates and therefore preferred dirt. Only the abolition of plural voting and the control of the City Council by the citizens would end "the ravages of preventible diseases". 77

Critics might argue that the polemical, muckraking style of the Clipper led it to exaggerate the environmental inequalities endured by the lower classes and smaller ratepayers in Hobart and painted too black a picture of landlords. 78 In part this accusation has validity but the liberal paper the Tasmanian News formulated a similar critique. In March 1900, for example, it depicted "the cleansing of the city and the adoption of proper sanitary arrangements" as "a fight between the interests of capital, of bricks and mortar on the one hand, and of the health and the very lives of the people on the other ..." 79 It saw in such inequalities

74. Ibid 10 September 1898.

75. Ibid 5 December 1896.

76. Ibid 26 March 1898.

77. Ibid 10 September 1898.

78. R.P.I.G. 5 July 1897 denied charges that landlords were "selfish, rapacious and arbitrary" and "being so alive to their own interest that common humanity is lost sight of ..." just because they derived rent from houses or land.

79. T.N. 30 March 1900. 
"no more complete and convincing object lesson of the viciousness of class ascendancy in Australia". 80 Visitors to the city, for instance Ben Tillett in 1898, observed that plural voters were "fast bringing the city into ruin and disrepute". 81

Many of the political reform groups of the 1890 s included municipal reform as an integral part of their platform. One example was the Democratic League, formed in November 1896 to achieve radical political and social change, which sought the reduction of plural voting, the election of the Mayor by the citizens, an improved water and sewerage system, municipal socialism and amendments to the Building Act to improve "the appearance and sanitation of the city". 82 One of its founders was James Paton, editor of the Clipper. On 8 December Paton convened "a mass meeting" of the Democratic League to discuss "the evil of plural voting". 83 Paton described the deplorable sanitary arrangements of the city and argued that as the Council "had always been controlled by the bricks and mortar vote, therefore it was landlordism that was responsible for the present state of affairs". Conservatives opposed the democratisation of the Council, crying "a stake in the country" but there was "no more responsible stake than the welfare and health of the individual voter and his family". Paton deprecated Parliament for, during the last session, passing a clause in the Hobart Corporation Act 1896 entitling owners to the same number of votes as occupiers of their property. This gave property owners extra votes and made it "extremely difficult to run a populist candidate". The meeting protested against "the large

80. Ibid 24 November 1899.
81. Cl. 3 September 1898.
82. Ibid 26 November 1896; Reynolds, op.cit., p.234-5.
83. $\quad$ Cl. 12 December 1896.


increase in plural voters" and demanded wholesale reform of the Council but this was not forthcoming before 1900. Thus it is clear that public health in Hobart was a political issue, involving questions of who had power over the city's environmental development and how that power was used. From 1901, as we will see, reform of the munzcipal franchise produced keen political debates in Parliament and at public meetings and alteration to the franchise was regarded as an essential pre-requisite to making the Council more socially responsible.

Despite the pressure exerted by those seeking sanitary and municipal reform in the 1890s, it was not until 1900 that some headway was made. In 1900 the Clipper and the Tasmanian News directed their attacks against George Davies, who was seen as a symbol of reaction. His father John Davies, a Jew, arrived in Hobart as a convict in 1831: by 1860, with luck and industry, he had established the Mercury as the city's largest newspaper. 84 In 1871, one year before his father's death, George, with his brother Charles, became owners of the paper. The Mercury was used by George Daries to consolidate his standing in public life. In 1884, at the age of 38 , he was an alderman and member for Fingal in the House of Assembly where, in 1892, he became chairman of committees. He maintaıned an independent political stance. Although joining the Liberal Party late in his career, he found the constraints of party politics uncomfortable. Davies' Jewish convict background must have prevented him from being accepted by the elite of Hobart society: his pursuit of the Mayoralty might have reflected a desire to confirm his social and economic status. From 1884 to 1901 Davies was Mayor a record six times. He was

84. A.D.B. v.4, p.27-8, v.8, p.233-4. For the Mercury's rise to prominence see Cyclopedia of Tasmania, op.cit., v.l., p. 292-3. 
able, wrote the Clipper, "by virtue of the influence of the daily press and .... plural voting power ...." to become Mayor whenever he wanted. 85 Davies favoured some sanitary improvements but had the conservative's congenital dislike of major change and resented the intrusion of outsiders into Council affairs. Davies and his circle had to go, the Clipper had decided, because "under their regime all unspeakable corruption flourishes". 86 The Tasmanian News wrote of an "inner circle" who felt they had "a supreme right to divide aldermanic honours between them". 87 There was "a general impression - so strong that it amounts to a belief - that al1 civic authority has passed into the hands of a coterie ...." 88 The Tasmanian News objected to Davies because he was "the leader of a party, which had defied public opinion" and intimated to deputations that "the Council intended to do as it liked ....": it protested against Davies' "claim to a monopoly of the position" of Mayor. 89

The newspaper campaign failed to prevent Davies being reelected Mayor for 1901, the third year in a row, by his fellow aldermen but all' was not lost. In November 1900 public controversy over the water supply laid the foundation for renewed attacks on Davies in 1901. Debates concerning the supply of water had occurred on and off for "the last seventeen years at least". 90 The Hobart Water Act 1860 vested the Hobart Corporation with

85. C1. 25 August 1900.

86. Ibid.

87. T.N. 26 November 1900.

88. Ibid 10 December 1900.

89. Ibid 17 December, 12 December 1900.

90. M. 2 November 1900 a comment by Herbert Nicholls during debate on the Hobart Water Bill in the House of Assembly. 
management of the water supply for city and suburbs. In 1893

the suburban bodies felt their districts were being neglected and petitioned Parliament to create a Water Trust. ${ }^{91}$ The suburbs were charged a higher water rate than the city to subsidise, claimed the Corporation, the construction of new mains. The mains were not built and the suburbs alleged that the Corporation used the money for other purposes. Also unfair, they argued, was that their views were not sought when decisions were made on the expenditure of money borrowed by the Council. A Select Committee found the complaints of inequity justified but a Water Trust was not formed. 92 In 1900 another Select Committee, under the chairmanship of William Perkins, a lawyer, member of the Sanıtary Association and long-time critic of the Council, also confirmed the financial inequities. 93 In addition it noted that the main water supply from Mt. Wellington and other sources were diminishing and it was "quite evident that the quantity obtainable in former years is not now available". Water was very scarce in summer and in recent years often had to be cut off for several hours. In the suburbs the construction of mains and pipes had not kept pace with the growing population: the suburbs were not permitted to use water for flushing gutters "or other public sanitary requirements". The Select Committee recommended the establishment of a Water Trust to construct a new water supply system, costing $£ 205,000$, to bring water from the River Styx.

91. T.P.P. $1893 / 98$.

92. T.P.P. 1893/102. For an instructive analysis of the concept of equity in the provision of water in a modern context see J. Rees, "Urban and Sewerage Services" in P.N. Troy (ed.), Equity in the City, (Sydney, 1981), p.85f.

93. T.P.P. 1900/51. 
A vigorous public debate ensued. The Clipper underlined the seriousness of the report by alleging that due to "the gross maladministration of a series of Municipal Councils" the water supply had reached "a critically bad state".94 One reservoir had "practically collapsed": mains and pipes were faulty and some were broken. At a tense public meeting aldermen argued that the approach of summer and the tourist season militated against a complex scheme: the salubrious reputation of Hobart required an immediate solution. 95 The meeting carried a motion for a permanent solution. Parliament reached a compromise. ${ }^{96}$ The Corporation was allowed to use water from the North West Bay River for two years: in the interim a permanent solution had to be found.

It was doubtful that the Corporation, given its past record, would come up with a proposal that was fair to the suburbs. Also the government of Hobart and suburbs, with the proliferation of local authorities, was due for review. After the elections of May 1900 the march of liberalism had resulted in the most progressive House of Assembly yet seen. The liberal members' of Hobart saw a chance to substantiate their accusations of wholesale Council neglect and persuaded Parliament that a major enquiry into municipal government was warranted. Hence, on a motion by Herbert Nicholls, a Royal Commission was appointed to enquire into the constitution of the Hobart Corporation and the local authorities of New Town, Glenorchy, Moonah, Queenborough, Glebe, Mt. Stuart, Bellerive and Beltana and the administration of their districts, with particular regard to the water supply: the members of the

94. Cl. 10 November 1900.

95. M. 24, 30 October 1900 .

96. Ibid 1, 2 November 1900. 
Royal Commission were not to be paid. 97

The appointment was we11-received. The Mercury wrote that there was "year after year a great cry about reform" of the Hobart Council and a Royal Commission was "the best means by which all the facts may be learned". 98 While critical of the "extravagant abuse" of some municipal reformers, the Mercury perceived a consensus that somețhing had to be done "to place the municipal government of Hobart and suburbs on a wider and more useful basis ....": It favoured a Greater Hobart scheme. The federation of the Australian colonies in 1901 made reform even more desirable. The Tasmanian News believed federation would result in "more and more attention .... [being] bestowed upon local government and the care of the cities - in view of the increased competition which will come about - must be assiduously attended to. Hobart must learn the art of 'dressing the window' .... to attract custom and the whole establishment should run upon up-to-date lines". 99 Some reformers hoped that the Royal Commission would lead to a policy of municipalısation carried out, as we have been, by British cities and, closer to home, Launceston. 100

Opinion differed then as to how municipal affairs should be re-organized: a Greater Hobart, thé creation of a Water Trust, a federal system similar to the London County Council or the Glasgow model of amalgamation were possibilities. ${ }^{101}$ The direction, if any, change would take would be substantially determined by the members of the Royal Commission. They included W.A. Guesdon,

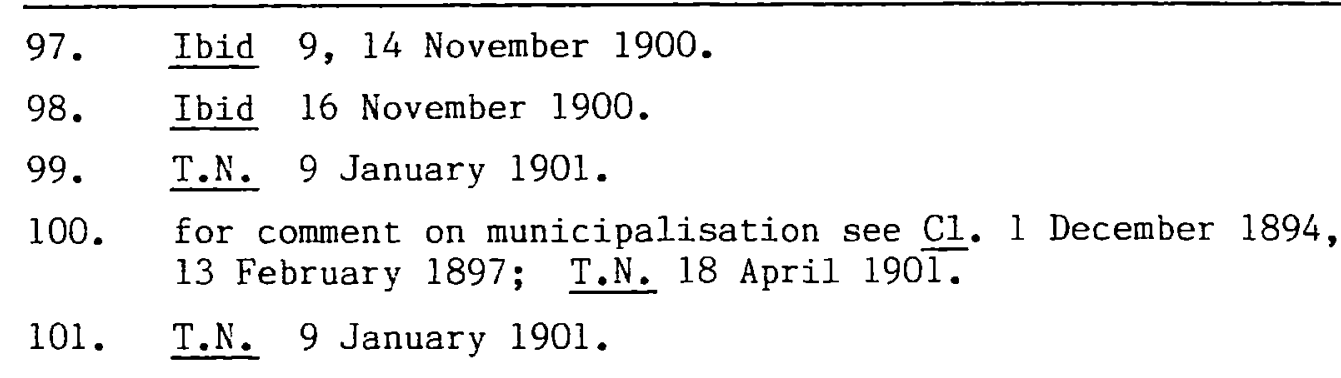


Herbert Nicholls and W.B. Propsting, all of whom had been members of the Hobart Sanitary and General Improvement Association and R.C. Patterson: they were of liberal democratic persuasion and dominated affairs. 102 George Davies, another member, could only attend two meetings but gave evidence before the Commission. Edward Mulcahy, the Minister of Lands, was too busy to attend any meetings. The remaining member was John Hamilton. The report, after evidence had been taken from over 40 witnesses, including officials of the Launceston Corporation, was very critical of the Hobart Corporation: "in many respects there is room for improvement in the administration of the affairs of Hobart". 103 The duties of the Town Clerk and City Accountant were not defined. The Mayor discharged "some of the proper duties" of the Town Clerk and "even upon occasion communicates (as do some of the aldermen) directly with the departments of the Corporation without the Town Clerk's knowledge". 104 Financial administration needed "some remodelling". It was hard to establish the financial state of the Corporation and the Statement of Accounts published in the Gazette was incomplete. The Health department was characterised by divided control between the City Surveyor and the Health Officer. Sanitary defects, to be discussed in later chapters, loomed very large. The City Council did not, as it was empowered, make "any serious attempt to compel" the Hobart Tram Company to upgrade its service: the tram system was "undoubtedly a discredit

102. M. 10 April 1900 for a meeting to re-establish the Sanitary Association.

103. T.P.P. 1901/5. What follows is a summary of the major findings and recommendations of the report.

104. This finding was derived from the evidence of George Steward who had acted as Town Clerk for five months in 1897 before resigning because the duties of the Town Clerk were "very largely" discharged by aldermen. Ibid, p.112. 


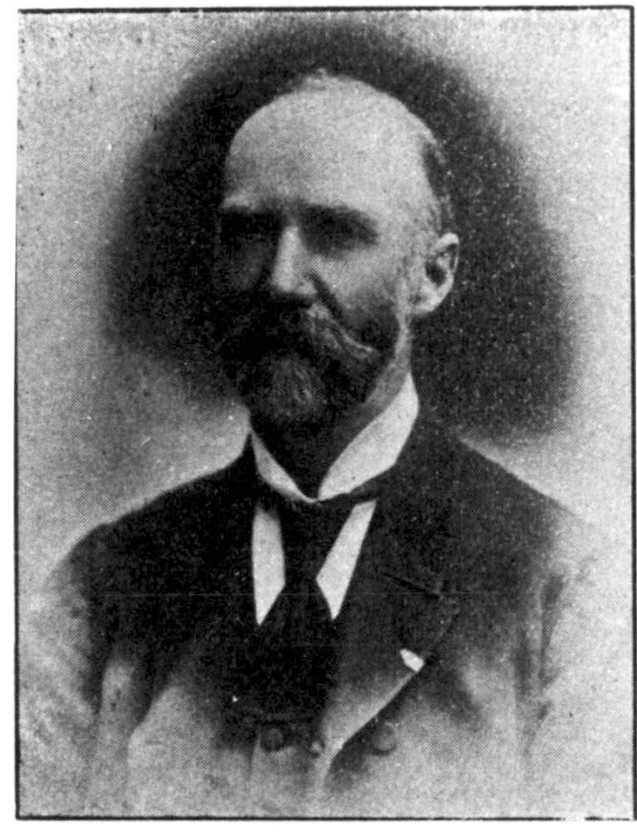

P. M GUFFIE \& CO.

Mli, J. Brantey.

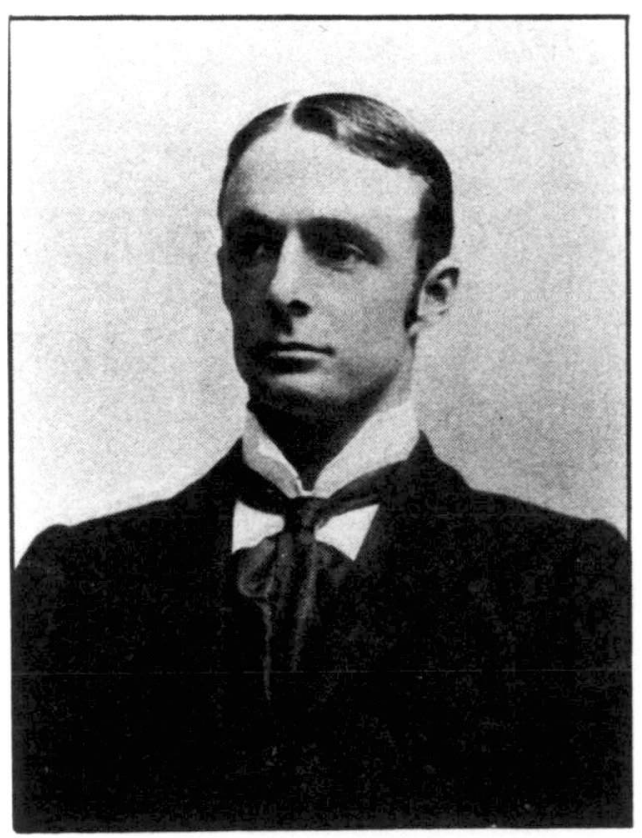

Discouffie aco.

HOBART IL. II Nicholds.

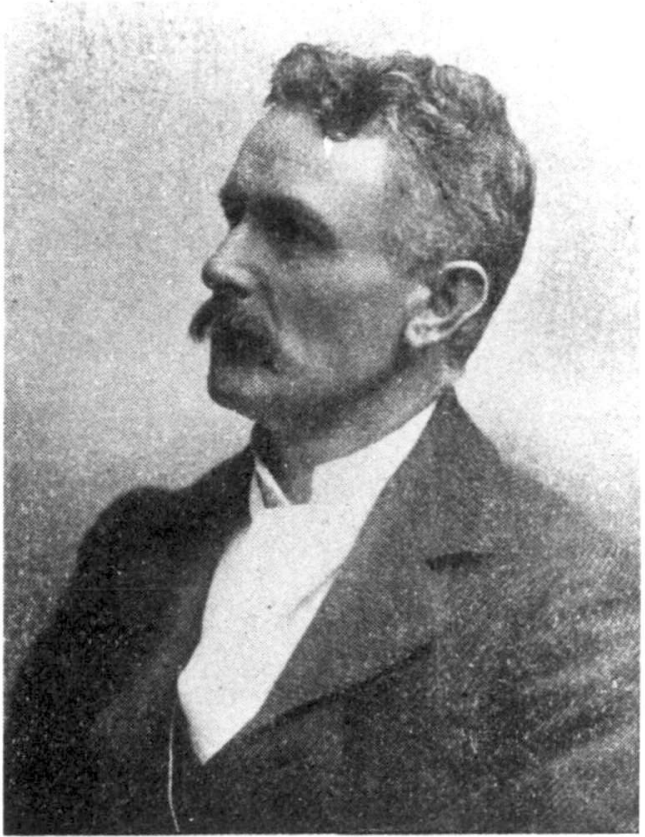

ค. MCGUFFIE \& CO.

Mr. E. Mon, Muly.

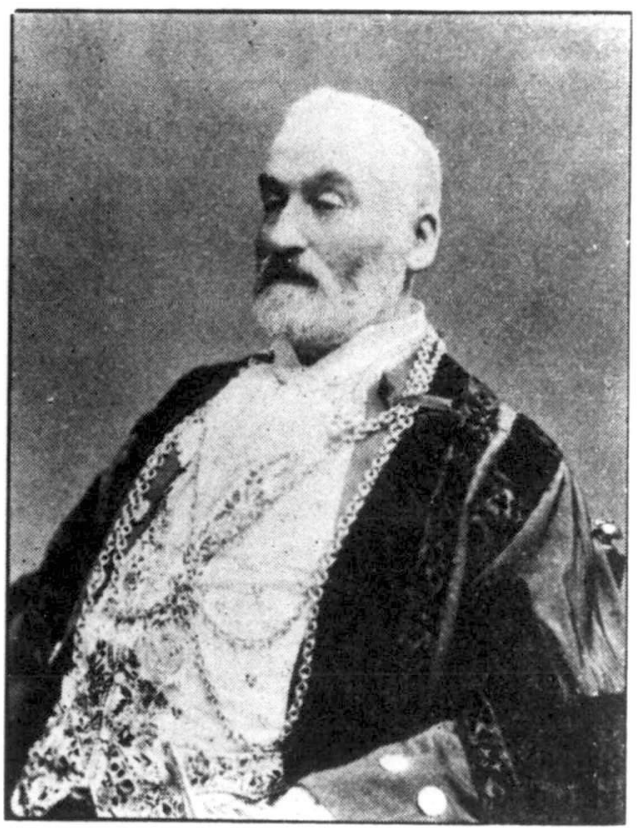

R. MCGUFFIE \& CO.

Mr. J. (;. D) Dres. 
to the community" and should be acquired by the Government.

The benefits, particularly of a sanitary nature, of a Greater Hobart were stressed. These included uniform systems of drainage and the collection and disposal of household refuse, including the purchase of a refuse destructor; the construction of a modern slaughteryard; and "the proper conduct and maintenance" of the trams. A contentious recommendation was that "one administrative body" should control and manage the water supply and an underground drainage scheme. In Melbourne the Metropolitan Board of Works administered the two departments, which were "so closely allied that they will not admit of any separate or divided responsibility in their administration, if proper regard is to be had to the interests of the public or to efficiency and economy in management and working". The report concluded with two planks of the democratic platform. It was "impossible to radically alter the condition of affairs under the present system of piecemeal retirement of aldermen": citizens would profit if all aldermen retired at the same time. Finally as the Mayor exercised "such large administrative powers .... it would be advisable in the public interest that he should be directly elected by the people".

The Royal Commissioners took six months to produce the report, an impressive document providing a blueprint for change. Most of the recommendations were not radical and if Implemented would merely bring the Hobart Corporation into line with its Launceston counterpart. The members, thought the Clipper, had performed their duty "with impartiality and skill": the reforms were "urgently required". 105 The Mercury perversely clalmed that the report did not "add greatly to the sum of human knowledge" but acknow- 
ledged that there was "room for and need of reform in some of the municipal arrangements", especially in sanitation. ${ }^{106}$ The

Mercury made a valid point when it argued that the report failed to discuss the limited funds at the Council's disposal: "unless some plan can be devised to provide further funds without further taxation" fundamental improvements were not possible. ${ }^{107}$

However the Council's finances were interpreted, the report incriminated the Davies' clique by implication if not by name and gave impetus to those seeking the clique's removal. ${ }^{108}$ In September 1901 a new anti-Davies paper, the Citizen, was published and was welcomed as an ally by the Clipper: it was printed at the Tasmanian News office and was edited by Ronald Smith, "a brilliant journalist" and one time classmate of Alfred Deakin. 109 Smith's reputation as a democratic reformer was established durıng his editorship of the Tasmanian Democrat. Successfully backed by the Democratic League in the 1897 elections to the House of Assembly, he was not re-elected in 1900. Under his guidance the Citizen had "a clearly defined and emphatic purpose": it was tó turn "the searchlight of public opinion full on the Municipal doings" of Hobart. 110 The Royal Commission disclosed "the existence of a regime of muddle and mystery, the operations of a clique dictatorship .... and it proves beyond all question that Civic affairs are ripe - and over-ripe. - for reform". Each issue of the

106. M. 15 August 1901 .

107. Ibid 31 October 1901.

108. Minor examples of corruption associated with Davies were exempting the Theatre Royal, owned by his brother Charles, from paying rates for long periods; all Corporation printing was done by the Mercury; Davies' son-in-law was manager of the Tram Company, which was left alone by the Corporation even though it destroyed sections of the streets. Citizen 7 September 1901.

109. Cyclopedia of Tasmania, op.cit., v.1, p.96-7.

110. Citizen 7 September 1901. 
Citizen contained a column entitled "Readings for Ratepayers" in which all aspects of municipal reform, particularly sanitary, were broached. Davies' deficiencies were accented and he was challenged to seek re-election. He did not. He was acutely aware that the winds of change were blowing his way. In 1901 he became a Companion of the Order of St. Michael and St. George and defeat at the election would be a dent to his prestige. He did not enter municipal life again. With its objective achieved the Citizen ceased publication in November 1901.

What other immediate results did the Royal Commission achieve? In October 1901 Patterson moved in the House of Assembly that the recommendations receive the early attention of the Government: the motion was carried by 13 votes to $12 .^{111}$ The Government took no action. In March 1902 J.C. Paton, H.T. Gould and George Moore, three progressive aldermen, initiated a report by the City Council on the recommendations. ${ }^{112}$ The Council was generally in accord with the sanitary recommendations but not those relating to executive and administrative reform. Financial limitations were emphasised: only if the Government provided money could major works, such as the River Styx scheme, be carried out. Public meet-. ings urged the Council to implement the recommendations. ${ }^{113}$ Some sanitary improvements were introduced but nothing else. It would be wrong, however, to judge the report on its immediate impact. Prepared by respected men, the report kindled the flames of municipal reform and the flames could not be extinguished. By the end of 1914 most of the recommendations had been adopted, as the

111. M. 31 October 1901 .

112. Ibld 18 March, 15 April 1902.

113. Ibid 23, 27 September 1902. 
Hobart Corporation launched its most progressive era. The Town Boards of Glebe Town, Wellington and Mt. Stuart in 1907, and the municipality of Queenborough in 1913 were amalgamated with Hobart, leaving only New Town out of a Greater Hobart. 114 An expensive new slaughteryard was completed in 1909. ${ }^{115}$ In January 1913 the Corporation took over management of the metropolitan drainage scheme from the Metropolitan Drainage Board: on 1 July 1913 the Corporation bought the trams for $£ 210,000 .^{116}$ Buying out the Gas Company was discussed but not attempted, although a contract was concluded with the Hydro Electric Power and Metallurgical Co. Ltd. to supply the city with electricity from 1913. ${ }^{117}$ The River Styx scheme was not started but the Corporation was given a permanent right to take water from North West Bay and construction of the new Ridgeway Reservoir was underway. ${ }^{118}$ Recreation grounds were gradually taken over and in 1914 a rate of 1d. was levied for their upkeep. 119 A large ha11, market and shops were under construction. ${ }^{120}$ Sanitary reforms, as we will see, were instituted. By 1915 the Council controlled "all public utilities with the exception of street lighting". 121

The extension of municipal services has to be seen against the background of post-federation properity. In 1911 C.E. Webster, a leading figure in the Chamber of Commerce, commented, at a meeting of the re-organised Builders and Contractors Association, that

114. Hobart Corporation Act 1907; Hobart Corporation Act 1913. 115. M. 25 February 1909.

116. Hobart Sewerage Act 1912; M. $_{1} 10$ December 1913.

117. M. 30 October 1906, 13 November 1907, 10 December 1913.

118. Hobart Water Act 1905; Walch's Tasmanian Almanac 1914, p.327-8.

119. Hobart Corporation Act 1913 Part II.

120. M. 8 December 1914.

121. Ibid. 
"When there was general prosperity it was always indexed in the building trade, as prosperity was a sort of medium which cultivated the building microbe". ${ }^{122}$ From 1906 to 1914 building was very rapid. (Table 14) In 1913 Mayor Alfred Crisp, who had a long involvement with the building trade, said Hobart "was never in a more prosperous and flourishing condition, with buildings going up in every direction". 123 General prosperity encouraged the Council to become more active and aldermen realized that in order to raise revenue money had to be spent and not guarded. Thus Crisp explained that the Corporation borrowed heavily "for the purpose of increasing the attractiveness, progress and prosperity of such a beautiful city. By such means the present City Council believed the number of visitors, tourists and residents would continually increase, and so thereby would the revenue of the Corporation". 124

TABLE 14 : VALUE OF PROPERTY BUILT IN HOBART

\begin{tabular}{|c|c|}
\hline Year & $\hat{\Sigma}$ \\
\hline 1906 & 42,000 \\
1907 & 47,000 \\
1908 & 51,000 \\
1909 & 48,000 \\
1910 & 71,000 \\
1911 & 98,000 \\
1912 & 82,000 \\
1913 & 73,000 \\
1914 & 120,305 \\
\hline
\end{tabular}

Source: D.P. 25 December 1914 .

122. Ibid 1 May 1911.

123. Ibid 25 August 1913.

124. Ibid. 
Civic pride also assumed a new importance. In 1911 Mayor Thomas Amott said aldermen were intent on making Hobart "a model municipal metropolitan centre". ${ }^{125}$ Aldermen were fortified in their endeavours, continued Amott, by "the general wish of the ratepayers that our city shall in every way be brought up-to-date, and kept in a condition befitting its importance as the capital of the State". Others remarked on this change. In 1913, for example, the Mercury was in no doubt that Hobart's residents had "recently awakened to a new civic consciousness", and had "developed a new civic patriotism". ${ }^{126}$ Consequently Hobart would soon become what it was destined to be "the Queen City of the Commonwealth". ${ }^{127}$ Related to the growth of civic consciousness was that, by the early 1900s, an informed assessment of the success of municipalisation in Great Britain and elsewhere could be made. Control of public utilities was no longer regarded as an experiment conducted by adventurous Corporations but was recognised to be an essential feature of urban government. The Clipper, always a proponent of municipalisation, noted in 1904 that "Municipal enterprise in most cities of the Empire is considered the success of the age". ${ }^{128}$ In 1906 it formulated a lengthy municipal platform in which municipalisation of utilitıes was promenent. ${ }^{129}$ A similar opinion was held by the Daily Post, begun in 1907 as a daily paper advocating the "democratic Liberalism" of Deakin but from

125. Ibid 5 December 1911 .

126. Ibid 29 November 1913; also Critic 14 January 1911; T.N. 17 November 1911.

127. M. 2 June 1914 .

128. $\mathrm{C1}$. 12 November 1904; see also Ashford, Infra, fcotnote 62. 129. Cl. 30 June 1906. 
late 1909 became increasingly orientated towards the Labor Party. ${ }^{130}$ In November 1909, when arguing for a municipal housing programme, the Daily Post wrote that "The modern tendency is wholly in the direction of making the functions of municipal government embrace all agencies connected with the interests of the town". ${ }^{131}$ It was accepted "the wor1d over", asserted the Tasmanian News, that local government "in its full sense" included "the control by the council of all services which may be designated communal benefits". 132 The Launceston Corporation illustrated this trend and the Tasmanian News looked forward to the Hobart Corporation "emulating the deeds of the Northern body".

The Mercury cautioned against a blind acceptance of a policy of municipalisation. It agreed that notable successes had been achieved in Glasgow and Birmingham but was less sure about London where the County Council's schemes were heavily criticised because of their cost and the large debt that had been amassed. ${ }^{133}$. Thus the Mercury believed that

$$
\begin{aligned}
& \text { No one can put down fixed limits to governmental } \\
& \text { or municipal action because what is possible and } \\
& \text { desirable in one set of circumstances is ruinous } \\
& \text { in another but we may safely conclude that any } \\
& \text { business not done in a business way is bound, } \\
& \text { sooner or later to come to grief. } 134
\end{aligned}
$$

130. D.P. 27 May 1908 and Reynolds, op.cit., p.283-4 for its philosophy; Cl. 9 October 1909 tells of Labor's takeover.

131. D.P. 20 November 1909.

132. T.N. 16 November 1911.

133. M. 11 February, 15, 27 March 1907 are examples of many editorials on municipal trading; D.E. Ashford, "A Victorian Drama: The Fiscal Subordination of British Local Government" in D.E. Ashford (ed.), Financing Urban Government in the Welfare State, (London, 1980), p.89.

134. M. 27 March 1907. 
The Mercury did not oppose the Council's acquisition of the trams: the keys to approval were improved and cheaper services. Aldermen were also smitten with the success of municipalisation. For example in 1904 Alderman George Moore, an engineer, proposed that the Council take over the trams and provide housing for the poor but he was, wrote the Tasmanian News, "incontinently sat upon". 135 Moore was defeated at the municipal elections of December 1904, "a warning" to those seeking municipal reform. ${ }^{136}$ But the warning was not heeded and later aldermen from all kinds of backgrounds advocated municipalisation of public utilities. In 1907 Mayor Charles Haywood, a biscuit manufacturer, supported the acquisition of the Gas Company, declaring that it was "in accord with munıcipal enterprise the world over". ${ }^{137}$ Earlier he had told his colleagues that "our positions as members of this Council are analagous (sic) to those of the directors of a company". 138 He wanted the Council's affairs to be managed "more effectively and economically" in the interests of "the comfort and safety of the citizens". Haywood was an early example of the businessman with a commitment to civic progress in the Joseph Chamberlain mould and the election of such men was becoming more common. Another exemplar was W.M. Williams, from 1911-13 President of the Chamber of Commerce and very successful businessman, who, as an alderman, had a special interest in public health and recreation grounds. 139 In 1914 Williams urged the Council to purchase the "electric undertaking" of the Gas Company

135. T.N. 18 February 1904.

136. Ibid 2 May 1905.

137. M. 8 January 1907.

138. Ibid 7 June 1905.

139. Ibid 12 August 1924 for William's obituary. 


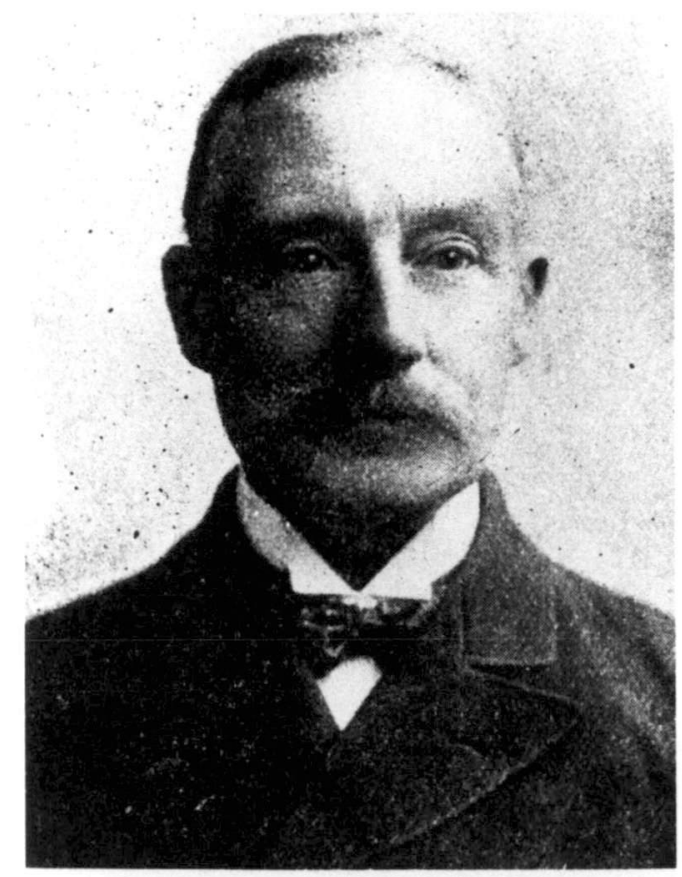

ALDERMAN T. BENNISON,

The Newly-elacted Mayor of Hobart.

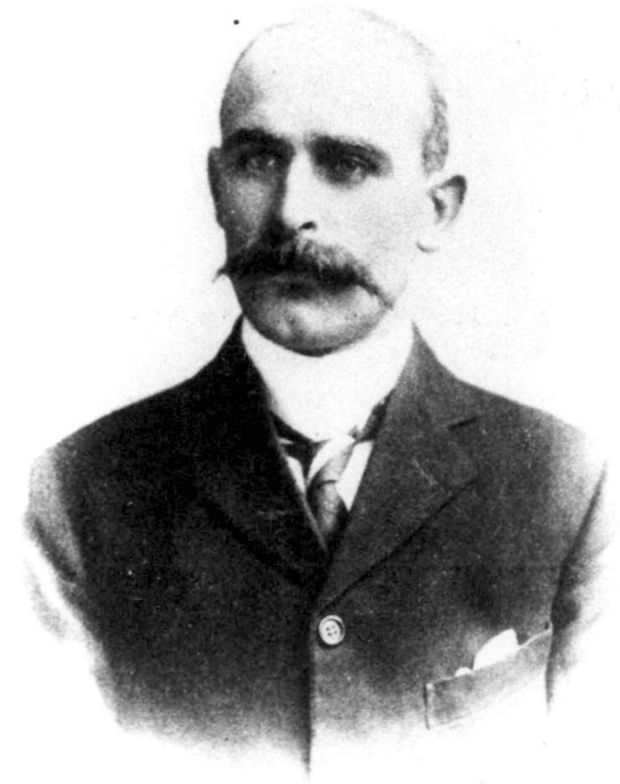

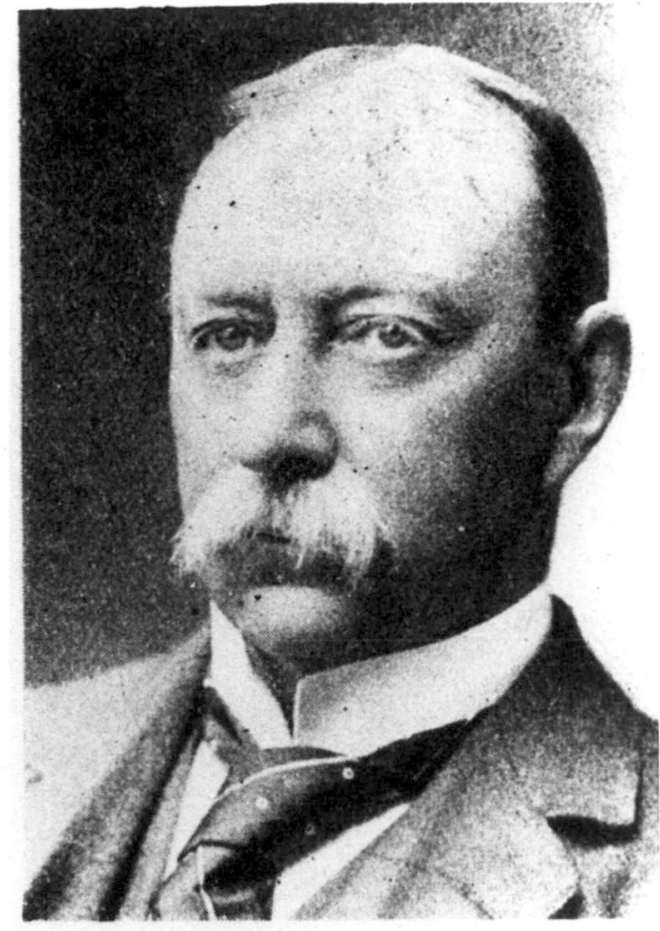

MR. G. E. MOORE, Wisi hoB. in'T

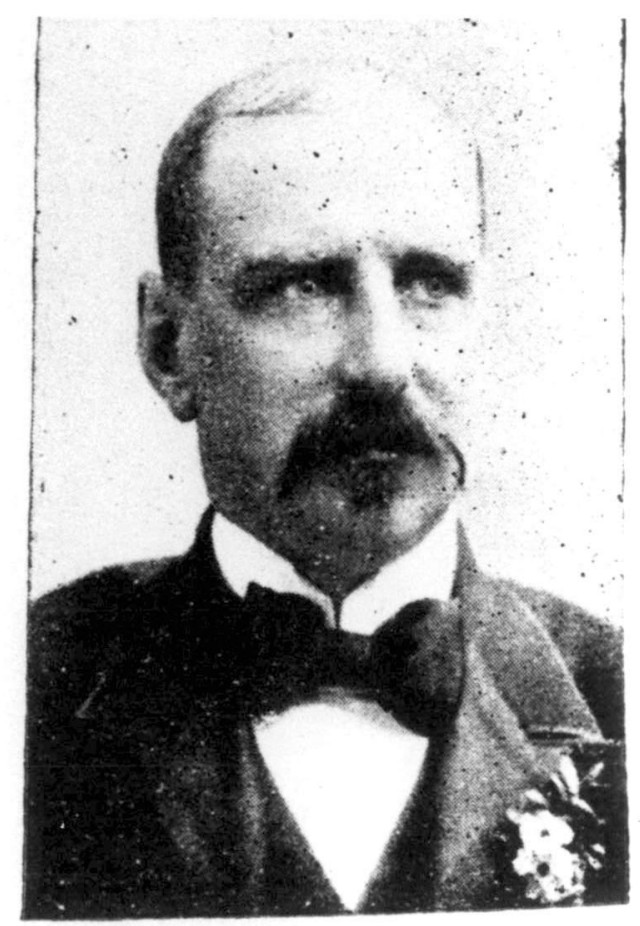

W. W. WIILIIJIS I,i\}. 
and pointed to 74 municipal bodies in Australasia supplying light and power. 140 If the Council managed this service, argued Williams, it could supply light and power to ratepayers at a lower cost and supplement the Council's revenue as the Launceston Corporation had done. R.J. Meagher expressed best the view of a growing number of aldermen. Meagher, who might have been associated with the Daily Post in its early years, was a member of the Public Service Board, a leader of the Australian Natives Association, and chief exponent of a Greater Hobart. ${ }^{141}$ In 1912 he said The work of civic government had got beyond the stage of roads, footpaths and bridges, and now embraced the control of all public utilities and everything that made for the betterment of the conditions of the people of the city. All work of that kind had been gradually coming to the City Council and as it had come along the aldermen had done their best to meet the obligations cast upon them. 142

Thus aldermen responded pragmatically to the needs of the city as they perceived them and as expressed by the ratepayers. The purchase of the trams illustrated this. Residents of West Hobart wanted a tram line: the Tramway Company seemed unwilling to build one. ${ }^{143}$ In 1911 the West Hobart Tramway Committee was established and persuaded the Council that a line was necessary. ${ }^{144}$

140. Ibid 20 January 1914.

141. The Tasmanian Cyclopedia, (Hobart, 1931), p.37-8; C1. 3 October 1908 refers to Meagher's association with the D.P.; R.W. Maning, "City Boundary Extension in Hobart", unpublished B.A. Hons Thesis, University of Tasmania, 1969, p.37.

142. M. 10 December 1912 .

143. Ibid 28 April 1911.

144. Ibid 9 May 1911. 
The only practical way for the Council to build a line was to take over the Tramway Company. The time was particularly opportune because the trams had begun to pay attractive dividends to shareholders and the cost of purchase, if left too much longer, would become very high. ${ }^{145}$ Public pressure eventually resulted in a poll of ratepayers in January 1913 to decide whether the Council should purchase the trams for $£ 210,000 .^{146}$ An overwhelming number of votes, 3439, were for the proposal and 905 were against: a large majority of those with seven votes voted for municipalisation. The favourable vote reflected a hope that the Council would extend the lines to neglected suburbs and provide "better and cheaper" services. ${ }^{147}$ Aldermen were not only sympathetic to the transport needs of ratepayers but saw defincte benefits to the Council. Mayor Amott, who was very influential in gaining aldermanic and public acceptance of municipalisation, saw a way to supplement municipal finances and in April 1911 bluntly told a public meeting that "We are after the profits". 148 Extending the trams, believed Alderman Freeman, "would enhance the value of the city property" and induce people to build and so increase the rates". 149

Men like Haywood, Amott and Meagher constituted what the Mercury claimed in November 1910 was "a municipal trading" party on the Council. 150 Municipal trading was a more accurate des-

145. T.P.P. $1911 / 48$, p. 3 and 10 .

146. M. 7 January 1913.

147. D.P. 13 July 1912, 17 January 1913.

148. M. 28 April 1911. In the first year of ownership from IJuly 1913 a clear profit of 4,230 was máde $\underline{M} .8$ December 1914.

149. Ibid 7 January 1913.

150. Ibid 17 November 1910. Freeman and Alderman G. Smith could be included. 
cription of their motıves than municipal socialism, with its ideological connections as defined in Chapter Two. As Fraser has written of Britain "The pragmatic rather than the ideological continued to spur municipal endeavour in both welfare and trading sectors". 151 Meagher denied an ideological motive. In 1913, when the shortage of housing was "acute", Meagher thought the Council should find out why and possibly provide housing for the needy. 152 Some might say, Meagher remarked, that this was "a socialistic idea, but he failed to see it": the Council represented "all sections of the community" and should help overcome the housing shortage if it could.

While the gradual enlargement of municipal functions brought to prominence issues like the acquisition of public utilities, sanitation remained the central issue of municipal politics from 1901 to 1914. The new civic consciousness, to a large extent growing out of the sanitary reform and tourist movements of the 1890s, demanded that the Corporation no longer evade its sanitary responsibilities. Thus a system of refuse removal was begun, a new slaughteryard built and a draınage scheme completed, albeit by the Metropolitan Drainage Board. Other responsibilities, such as more vigorously regulating noxious trades, inspecting factories, dealing with disused cemeteries, enforcıng building regulations and providing housing were more contentious, bringing the Council into conflict with important pressure groups and were not readily accepted, as we will see in Chapter Nine. Along with sanitation, other elements of municipal reform in the 1890 s were still to the fore.

151. Fraser, Power and Authorıty, op.cit., p.172.

152. M. 13 September 1913. 
After the Royal Commission report the Clipper and the Tasmanian News looked more closely at the Council's finances. The Clipper averred that Hobart was "one of the most heavily taxed cities in Australasia and its public utilities are the very worst". 153 It was not the lack of funds but the allocation and use of the funds raised that deserved criticism. The Tasmanian News had an alternative view. Referring to the incessant cry that the Council had no money for sanitary improvements, it thought that the level of rating was "too 1ow". 154 It 1isted the general rates levied by 17 Victorian towns of a similar size to Hobart and found the average was 1s. 11d. in the pound: Hobart's general rate was 1s. 4d. Samuel Sutton made a similar point. In Launceston, he said, residents were prepared to pay for city improvements but "the people of Hobart were in the habit of looking to the Government for support" and opposing rate increases. ${ }^{155}$ In 1885 Hobart's total municipal rates were $3 \mathrm{~s}$. 4d. In the pound: in 1901, although no longer controlling the police but now levying a sanitary rate, total rates were $3 \mathrm{~s} .3 \mathrm{~d} .$, as opposed to Launceston's total rate of $2 \mathrm{~s} .9 \mathrm{~d}$. and a general rate of $1 \mathrm{~s}$. (Table 15) It appears that the Clipper's claim was right: money levied from rates should have been adequate but was not used effectrvely. From 1901 the Corporation was constantly urged to spend more money on city improvement. In July 1902, for instance, in a public speech, Edward Mulcahy said there was supporting the Corporation "a sufficiently large majority of people [who] desired

153. C1. 23 November 1901 .

154. T.N. 18 August 1903.

155. M. 31 October 1901 in a speech on the Royal Commission in Parliament. 
TABLE 15 : HOBART CORPORATION RATES LEVIED IN THE POUND

\begin{tabular}{|c|c|c|c|c|c|c|}
\hline Year & General & Police & \multicolumn{2}{|r|}{ Sanitary } & M.D.B. & Recreation \\
\hline $1885-7$ & 1s. $3 \mathrm{~d}$ & $9 \mathrm{~d}$. & - & & - & - \\
\hline $1888-9$ & 1s. $3 \mathrm{~d}$ & $9 \mathrm{~d}$. & $4 \mathrm{~d}$. & & - & - \\
\hline $1890-1$ & 1s. $4 \mathrm{~d}$. & $9 \mathrm{~d}$ & $4 \mathrm{~d}$. & & - & - \\
\hline 1892 & 1s. $6 \mathrm{~d}$. & 9d. & $\begin{array}{l}\text { under } \\
12 \mathrm{~s} \text {. }\end{array}$ & $\begin{array}{c}£ 36 \text { over £36 } \\
6 \mathrm{~d} .\end{array}$ & - & - \\
\hline 1893 & 1s. $5 \mathrm{~d}$. & $9 \mathrm{~d}$ & $12 \mathrm{~s}$. & $5 \mathrm{~d}$. & $2 \mathrm{~d}$. & - \\
\hline 1894 & 1s. $5 \mathrm{~d}$ & 9d. & $12 \mathrm{~s}$. & $5 \mathrm{~d}$. & 3 farthings & - \\
\hline $1895-6$ & 1s. $5 \mathrm{~d}$. & $9 \mathrm{~d}$. & $12 \mathrm{~s}$. & $5 d$. & $\frac{1}{2} \mathrm{~d}$. & - \\
\hline 1897 & 1s. $4 \mathrm{~d}$. & $9 d$ & $12 s$. & $5 \mathrm{~d}$. & ld. & - \\
\hline 1898 & 1s. $4 \mathrm{~d}$. & 9d. & $\begin{array}{l}\text { under } \\
12 \mathrm{~s} \text {. }\end{array}$ & $\begin{array}{c}£ 30 \text { over } £ 30 \\
5 \mathrm{~d} .\end{array}$ & - & - \\
\hline 1899 & 1s. $4 \mathrm{~d}$ & - & $12 \mathrm{~s}$ & $5 \mathrm{~d}$. & - & - \\
\hline $1900-5$ & $154 \pi$ & - & under & $\$ 24$ over $£ 24$ & _- & - \\
\hline 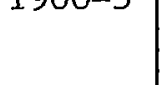 & $10 \bullet 40$ & s & $1200^{\circ}$ & & under $£ 20$ over $£ 20$ & \\
\hline 1906 & 1s. 6d. & - & $12 s$. & $6 \mathrm{~d}$. & 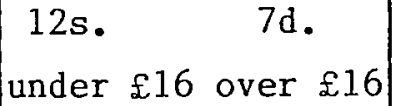 & - \\
\hline $1907-12$ & 1s. $6 \mathrm{~d}$. & - & $12 \mathrm{~s}$. & $6 \mathrm{~d}$ & 12s. $\quad 9 \mathrm{~d}$ & - \\
\hline 1913 & 1s. $6 \mathrm{~d}$ & - & $12 \mathrm{~s}$ & $6 \mathrm{~d}$. & $\begin{array}{cc}\text { under } £ 13 \text { over } £ 13 \\
12 \mathrm{~s} . & 11 \mathrm{~d} .\end{array}$ & - \\
\hline 1914 & 1s. $7 \mathrm{~d}$. & - & $6 s$. & 3d. & 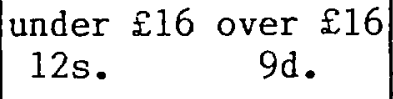 & ld. \\
\hline
\end{tabular}

TABLE 15 (continued)

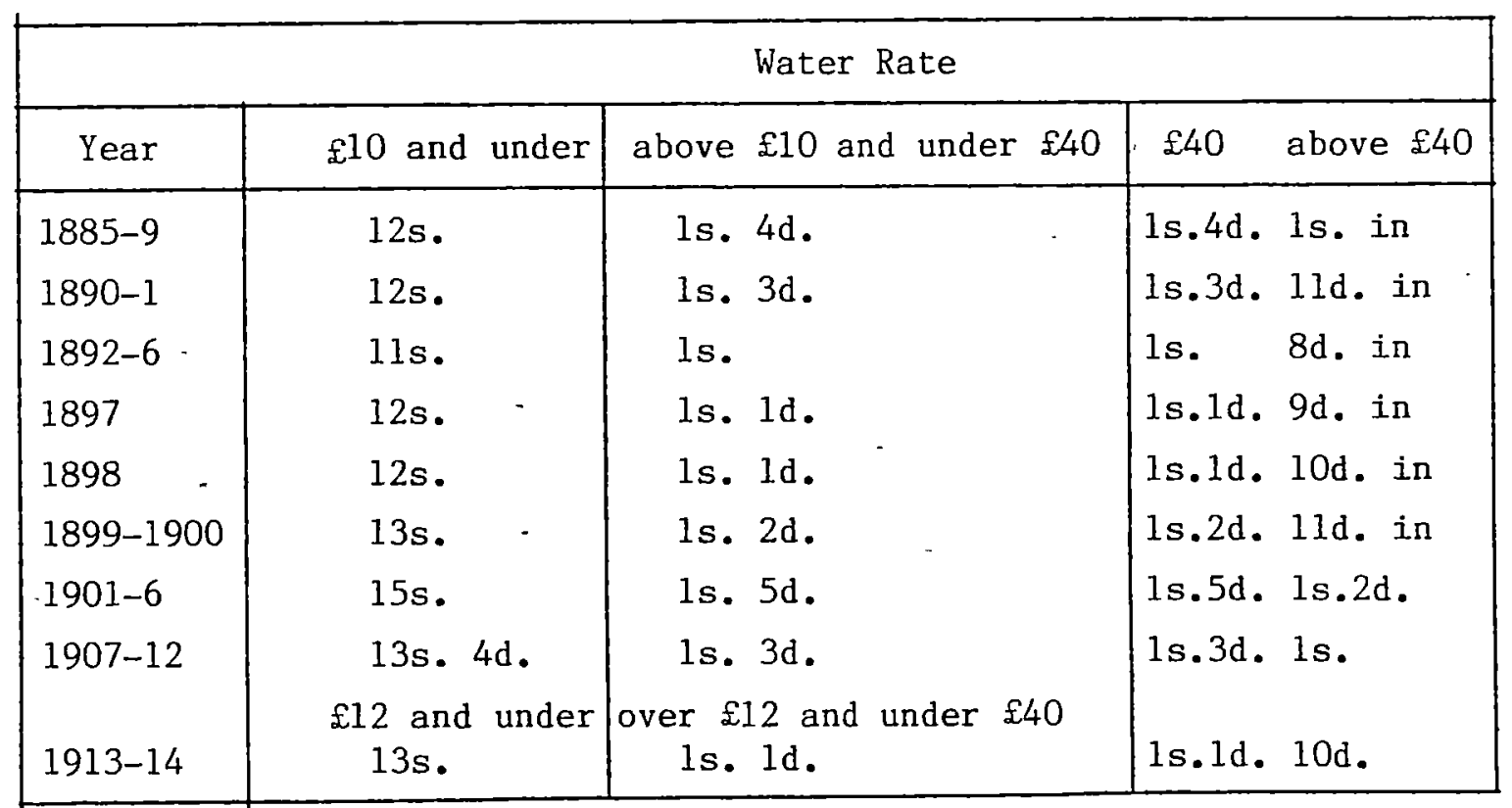


to avoid stagnation and would consider it wiser to spend a few pounds in improving the city, than not spending any at a11". 156 By 1906 even the Mercury thought the Corporation would be justified in increasing the rates because "with the erection of new buildings and the expansion of the city the duties of the Corporation will extend". 157 In 1906 2d. was taken off the water rate and added to the general rate: in 1914 2d. was taken off the sewerage rate, 1d. being allocated to recreation grounds and 1d. for the general rate to spend on city streets, which, the Mercury complained, had been deprived of funds for too long and were in a shocking state. ${ }^{158}$ Thus aldermen preferred to alter the proportion of rates levied for specific works rather than increase rates "and thereby running the risk of becoming unpopular". ${ }^{159}$ Aldermen were happy to fall back on the argument that annual rateable value was getting higher each year and there was no need to increase rates. 160

As was the case with the Launceston Corporation, the dependence on rates from real property caused most of the Hobart Corporation's financıal problems. In the prosperous decades from 1870 to 1891 annual rateable value increased from $£ 94,000$ to $£ 174,950$; fluctuations and different assessment procedures meant that by 1901 it was only $£ 173,813$; in the period of rapid building up to 1915 annual rateable value had reached a respectable $£ 308,112 .^{161}$

156. Ibid $16 \mathrm{July} 1902$.

157. Ibid 14 March 1906.

158. Ibid 14 March 1906, 31 March 1914.

159. Ibid 4 February 1910.

160. for example see Ibid 19 March 1912.

161. Knibbs, op.cit., p.139-40. In his review of the Council's financial position from 1885 to 1901, Davies emphasised the restrictions caused by the slow increase in annual rateable value. M. 3 December 1901. 
This outline seems to confirm the view that a major increase in annual rateable value was essential for improved "social conditions". 162 Such increases also gave the Council confidence to borrow large sums of money to subsidise expensive public works, most notably for the water supply and the purchase of the trams. In 1875 the Hobart Corporation's outstanding loans amounted to $£ 89,235$; in $1901 £ 249,900$; and in 1914 the amount had more than doubled to the£551,442. ${ }^{163}$ Parliamentary assent to secure these loans, usually on the London money market, was rarely withheld. Ratepayers sometimes expressed reservations about the increasing debt. In 1911 a section of residents in Queenborough used the large debt as an argument against amalgamation with Hobart, regarding the debt as "a burden". 164 This was, wrote the Tasmanian News, "a misnomer": it was "money invested in reproductive works and invested for the benefit of the citizens". 165 Without these loans urban life would have been much less attractive.

$$
\text { As we have seen it was often lamented that successful }
$$
businessmen did not become involved in municipal affairs but a turning point occurred in December 1900 with the election of Thomas Bennison, H.T. Gould and J.C. Paton. Their victory, wrote the Mercury, was "a very excellent one from a business point of view". 166 The Tasmanian News described the new aldermen "as thoroughly independent men" who would-conduct municipal affairs in a "business-

162. N. McCord, "Ratepayers and Social Policy", in P. Thane (ed.), The Origins of British Social Policy, (London, 1979), p.33.,

163. Knibbs, op.cit., p.139-40. Figures given by Meagher in December 1914 put outstanding loans at $\_799,841$ M. 8 December 1914.

164. T.N. 19 September 1911.

165. Ibid.

166. M. 14 December 1900. 
like way". 167 Gould, a chemist, and Bennison, an accountant and a member of the Central Board of Health, had both been prominent members of the Hobart Sanitary and General Improvement Association. Bennison was particularly well-regarded. Usually new aldermen had to gain experience on other committees before advancing to the influential Finance committee, but Bennison became a member in his first year because, as he said, finance "had been the study of his life". ${ }^{168}$ In 1903 Bennison was Mayor. He spoke of his "deep interest in sanitation" and noted "a determination on the part of aldermen", to remedy past sanitary defects and enlarge the Council's responsibilities. 169

Though the calibre of aldermen markedly improved after Bennison's election, the Mercury in 1907 still wondered why "those who have large interests in the city, and who, we might expect, would be very active in municipal affairs" did not seem interested and why "no proper steps" were taken to persuade them to enter municipal life. 170 No more than in Launceston, however, were there compelling economic reasons for businessmen to enter municipal politics. It is as difficult in Hobart as in Launceston to establish whether aldermen were the best businessmen. Like their Launceston counterparts, many Hobart aldermen had diverse financial interests. John Bradley, for example, a public servant until 1891, had interests in shipbuilding, local industries, mining and was a member of the Hobart Stock Exchange. ${ }^{171}$ The high property

167. T.N. 14 December 1900.

168. M. 18 December 1900; for brief details of Bennison's Iife see $\underline{\text { M. } 16}$ August 1921.

169. Ibid 25 February 1903.

170. Ibid 28 November 1907.

171. Cyclopedia of Tasmania, op.cit., v.1, p.85-6. 
qualification indicated that aldermen had substantial property holdings and a number, if not all, had seven votes, for instance W.M. Williams. 172

The complaint was not so much that aldermen were not businessmen, but that they did not employ the capacities that had made them successful in business when they became aldermen. ${ }^{173}$ After 1901 they did and it is noticeable that, almost without exception, those elected aldermen were described as successful businessmen. Although in terms of occupation they differed little from aldermen elected before 1901, there was a definite change in their outlook on the role of the Council in the city. (Table 16) Before 1901 men with progressive views were rare: after 1901 they became more common. Aldermen who espoused progressive views were usually associated with philanthropic bodies, such as the Benevolent Society, served on Hospital Boards and could be pillars of their church. 'More importantly, though political affiliations were hardly ever obvious from Council debates, progressive aldermen tended to support the liberalism of politicians like Herbert Nicholls: this was the case with Moore, Meagher, Williams, George Smith and Amott. 174 In short the mixture of business ability and social concern that was characteristic of Launceston aldermen, was also evident in Hobart aldermen between 1901 and 1914.

172. M. 6 December 1911 Williams said he had seven votes at a meeting to form a Progress Association.

173. T.N. 25 November 1896.

174. Moore's obituary says he "supported" the Nicholls-Propsting Government M. 13 August 1919; Meagher thought of contesting Denison as a Nicholls Liberal candidate $\mathrm{Cl} .3$ October 1908; Williams is listed as a Liberal in S. \& B. Bennett, Biographical Register of The Tasmanian Parliament 18511960, (Canberra, 1980), p.169; Smith contested the 1909 elections as a Liberal-Democrat, T.N. 30 April 1909, as did Amott in 1912 D.P. 22 April $1 \overline{912}$. 
TAELE 16 : OCCUPATIONG OF HOBART ALDERMEN

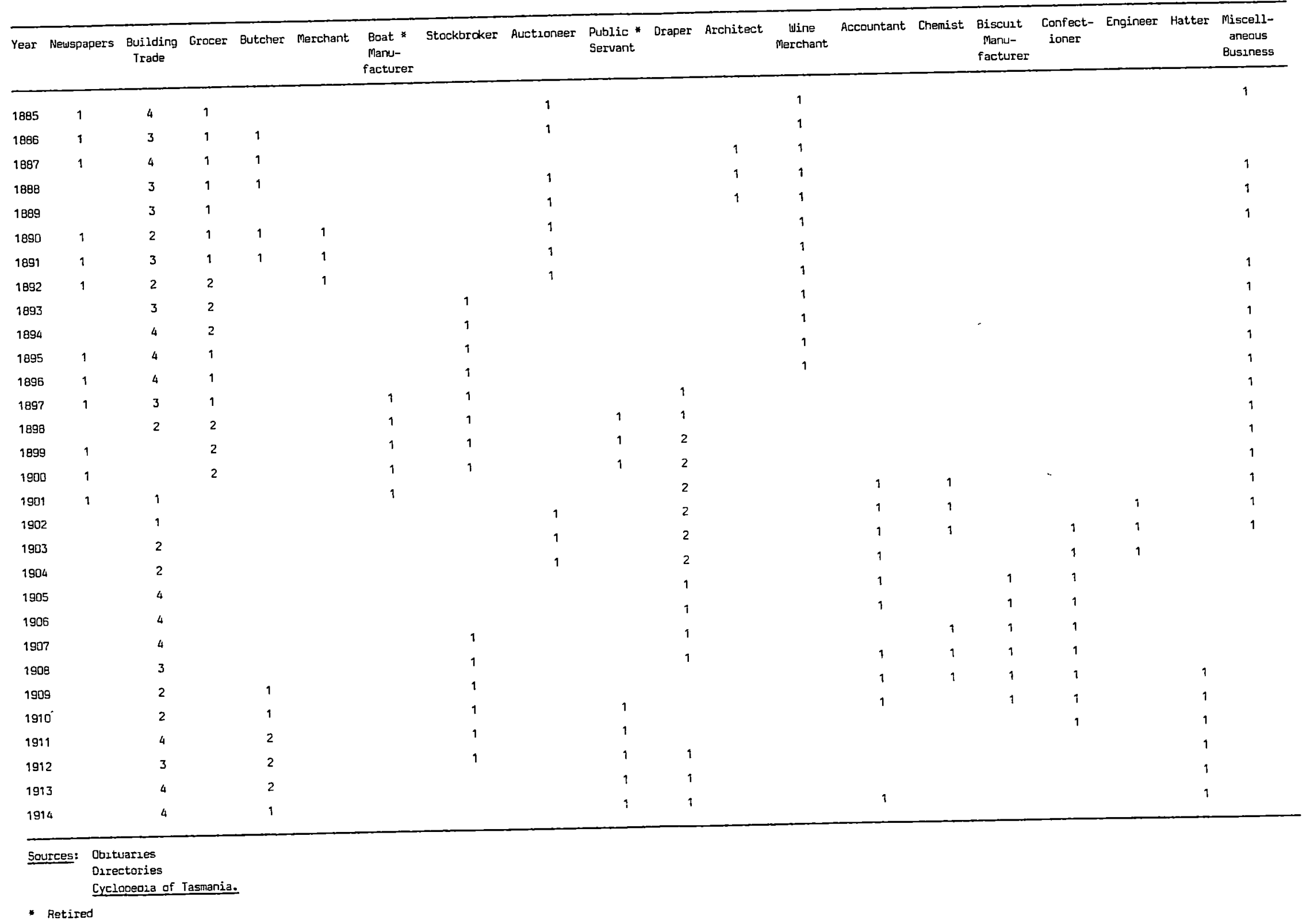


Alteration to the municipal constitution of Hobart was still desired. Defeat at the 1893 poll virtually ended agitation for the ward system. It was, however, momentarily raised when amalgamation of Glebe Town, Wellington and Mt. Stuart was considered in 1907 as they were worried that their interests would be neglected in a Greater Hobart and wanted separate representation on the Hobart Corporation. ${ }^{175}$ Finally they were satisfied with the inclusion of clauses in the Hobart Corporation Act 1907 that money raised in their districts would be spent on improvements there. 176 Each local authority, said Mayor Haywood, accepted assurances that they "would be fairly and justly treated". 177 A table prepared by the Town Clerk justified this claim. From January 1908 to 30 September $1913 £ 1,394$ was raised in Glebe Town and $£ 1,995$ spent; $£ 2,534$ was raised in Mt. Stuart and $£ 3,452$ spent; and in Wellington $£ 2,843$ was raised and $£ 6,548$ spent. ${ }^{178}$ The ward system was also briefly mooted during negotiations with Queenborough over amalgamation with the city but was dropped in return for financial assurances and the condition that for five years two extra aldermen would be elected by the ratepayers of Queenborough under the franchise of the Local Government Act 1906.179

A concerted attack on plural voting was inspired by the findings of the Royal Commission. So keen were the challenges to property interests, and not only in the municipal sphere, that

\footnotetext{
175. M. 24 July 1907.

176. Hobart Corporation Act 1907 clauses 6 to 8.

177. M. 3, 7 December 1907.

178. Ibid 14 October 1913.

179. Ibid 16 JuIy 1913; Hobart Corporation Act 1913 Parts IV and VI.
} 
in July 1901 the Hobart and Suburban Property Owners Association was formed, reaching 214 members in 1908 and acting as a political pressure group until August 1912. ${ }^{180}$ The Citizen argued for a broad franchise because until it was achieved "the process of reform must be slow .... and Hobart must continue to be branded as the most conservative of the world's municipalities". 181 In September 1902 a public meeting convened by Herbert Nicholls discussed amendments to the Council's constitution to bring it "into more direct agreement with the opinion of the ratepayers". 182 Suggested reforms were retirement of the majority of aldermen at one time, an increase in the number of aldermen, division of the city into wards, to abolish the provision allowing the owner and occupier a vote for the same property, and to alter the franchise to make the number of votes held by single voters equal to those held by plural voters. The imbalance between single and plural voters was obvious. According to Nicholls plural voters "hopelessly swamped" single voters: 1,700 plural voters had 6,500 votes and single voters had only 3,500 votes. The reforms were put as resolutions and carried "almost unanimously". The Clipper perceived "a serious lack of the genuine ring" about the reforms because plural voting should be abolished not modified. 183

A Bill embodying most of the reforms was introduced into the House of Assembly by Nicholls, as a private member, in November. 184

180. T.N. 16 July 1901; M. 6 August 1908, 2 August 1912 .

181. Citizen 28 September 1901.

182. M. 23, 27 September 1902.

183. $\mathrm{Cl} .27$ September 1902.

184. M. 4 November 1902 . 
In December, during the second reading debate, Nicholls explained that the proposed reforms were based on "the Corporation Constitution of English towns". ${ }^{185}$ He stressed the clause reducing the maximum number of votes for plural voters. Nicholls was strongly supported by the Hobart members. William Guesdon claimed that "the centre of the city could, and did, return any aldermen they chose": the large property owners "held all power in their hands". Thus "the people in the city suffered from the shortcomings of the City Council, not the wealthy people who lived in the suburbs". It seems that large property owners with business interests in the city centre, but who lived in the wealthier suburbs were the recipients of Council largesse. Edward Mulcahy believed that "such a magnificently situated city .... should be, and could be, made a model of cleanliness and good appearance". Instead streets "contained filthy, tumbled down homes and buildings, which would be counted a disgrace to a tenth-rate Chinese village". Aldermen represented not "the citizens as a whole but the property owners" who, "as a class", lacked public spirit "to make the mosit of the city". The views of the Hobart members were captured by Davenport Hoggins, a lawyer, who said: "Public right must stand superior to private rights, especially in a city which might be the sanatorium of the Commonwealth". In committee Propsting moved that the maximum number of plural votes be five, equal to that of Launceston and this was passed. Even the Mercury agreed with the reduction and admitted that in the past property had "the pull" and that "its power may be curtailed without much damage and with some possible gain". ${ }^{186}$ Another clause, however, abolishing all property qualifications for aldermen, was "open to

185. Ibid 5 December 1902.

186. Ibid 6 December 1902. 
the most serious objection". Municipal affairs were "mainly, if not entirely, concerned with questions, which in some way relate to property". People who run municipal affairs "should have something at stake themselves, as a guaranty that they will be cautious how they run into extravagance". In the Legıslative Council the bill was not debated. On the pretext that "not enough time" remained in the session to debate the Bill, it was ordered to be read in six months. 187

In November 1903 Alderman George Moore, now member for West Hobart in the House of Assembly, introduced, on behalf of the Corporation, a new Hobart Corporation Bill. ${ }^{188}$ It included various Improvement clauses but no clauses limiting plural voting. Moore said he would have liked to include such a clause but was not so advised by the Corporation. Nicholls, now the AttorneyGeneral in the new liberal-democratic Ministry of W.B. Propsting, was not deterred. ${ }^{189}$ In committee he moved that five votes be the maxımum for those owning property at $£ 150$ and over. The clause also overcame the system of double voting, which gave the owner and occupier of the same house a vote each, as only the occupier was given a vote. Acceptance of the clause would have been a signal advance. The vote was 12 for and 12 against. The Chairman of Committees had the castıng vote, He was George Davies. Davies voted against the clause.

187. Ibid 11 December 1902.

188. Ibid 14 November 1903.

189. F.C. Green (ed.) A Century of Responsible Government 18561956, (Hobart, 1956), p.211-12 for comment on the Propsting Ministry; also R.P. Davis, "Tasmania", in D.J. Murphy (ed.), Labor in Politics : The State Labor Parties in Australia 1880-1920, (St. Lucia, 1975), p.403. 
From 1904 to 1909 intermittent moves were made in Parliament to reduce plural voting but the press continued to be more demonstrative in its opposition. The Clipper, until it folded up in December 1909, the Daily Post, and the avowedly democratic and social reformist Critic, set up in 1905, which argued for a municipal franchise "as prevails in Great Britain and Canada", each published numerous editorials on the deadening effect of plural voting. ${ }^{190}$ An added stimulus to the campaign for an equitable municipal franchise was the involvement of the Labcr Party in municipal affairs. In 1910 the Denison Divisional Council of the Worker's Political League drew up a municipal platform, at the core of which was to give every occupier a vote. ${ }^{191}$ As the Daily Post wrote:

Every person who pays rates, whether much or little, should be given the municipal franchise .... That great benefits have followed democratic municipal government in Great Britain cannot be denied and it is reasonable to expect the same results here. The first step in that direction is the reduction of the franchise. 192

A wider franchise might result in, for example, the provision of housing by the Council but, the Daily Post asserted, the end of plural voting "can be advocated altogether apart from the benefits of the citizens which are sure to follow". This argument for the democratisation of the Council, apart from the social benefits that would accrue to residents from the abolition of

190. Critic 27 July 1907.

191. D.P. 12 October, 8 December 1910.

192. Ibid 12 October 1910. 
plural voting, began to be more frequently used. It reflected an awareness that the Council was taking on more functions: an equitable franchise would ensure that this trend continued and would speed up the process. 193

At the December 1910 municipal elections J.H. Cleary, a builder, was endorsed by the Labor Party. Although scoring the highest number of individual votes, Cleary only came fifth out of seven candidates. ${ }^{194}$ In January 1911 the retirement of an alderman gave Cleary another chance. The Anti-Labor forces must have been scared that Cleary would win as Alfred Crisp, a valued alderman, who had only recently retired after 25 years service, was arrayed against him. Cleary scored 64 more individual votes than Crisp, the only other candidate, but lost by over 1200 votes, mostly comprised of seven voters. 195 Cleary's defeat was a clear example of the strength of plural voting. By 1909, however, the Labor Party had emerged as the major opposition party in the House of Assembly, where it could seek legislative changes to plural voting. ${ }^{196}$ In December 1911 the leader of the Labor Party John Earle attempted to reduce plural voting to five, the same as in Launceston, where, he claimed, "a more liberal franchise had been instrumental .... in electing a more active Council". 197 Despite public support for the proposal, given by a short-lived Progress Association, it was unsuccessful. 198

193. As the Critic 16 October 1908 wrote "despite its absurd franchise" the Hobart Corporation was "slowly but surely" following a policy of municipalisation.

194. M. 9 December 1910; Bennett and Bennett, op.cit., p.34. 195. Ibid 20 January 1911.

196. Davis, op.cıt., p.412 for the rise of the Labor Party.

197. M. 1 December 1911.

198. Ibıd 6 December 1911. The Progress Association grew out of the Australian Natives Assoclation but little was heard of it in 1912. 
In 1913 the Labor Party's efforts were rewarded. During debate on the Greater Hobart Bill, L.F. Giblin, a Cambridge University trained economist and Labor member for Denison, moved that ratepayers only have one vote. ${ }^{199}$ Opponents of the Labor Party, for example Elliott Lewis, had no objection to a reduction in plural voting but were opposed to its abolition. Lewis pointed out that "Great progress was observable in the city and the work of the Corporation" and the Greater Hobart Bill contained many provisions that would assist the Corporation be more progressive. Edward Mulcahy, as we know a municipal reformer of long standing, also opposed "absolute equality of [the] franchise" but supported the adoption of the Launceston scale of voting. Mulcahy "congratulated the people of Launceston on their progressive public spirit, which existed side by side with plural voting, and it was hard to say whether the progress was due to the plural voting or not". Giblin's motion was defeated on the casting vote of the Chairman of Committees Robert Sadler. Giblin then moved that the maximum be three votes for those owning property valued at $\approx 100$ and over. As one of the opponents of his first motion had left the House, this motion was passed 14 votes to 13 . Other clauses moved by Giblin to make the Corporatıon more representative were defeated, except one making women eligible to become aldermen.

Municipal reformers, fearing alteration to the plural voting clause in the Legislative Council, requisitioned the Mayor to hold a public meeting. ${ }^{200}$ Giblin made a stirring speech in support of his motion. He cunningly argued that plural voting was introduced when Tasmania was "a penal settlement" and

199. Ibid 21, 27 November 1913.

200. Ibid 9 December 1913. 
To go on with plural voting was to admit that

the State was still a convict settlement and that was a slur on Tasmania. They should wipe out this stain on their past, by declaring that they were as fit to be entrusted with the principle of one man one vote as the cities of England. (Cheers)

A motion to that effect was carried. W.A. Woods, who had been a member of the House of Assembly for seven years but was ineligible to become an alderman because he did not own enough property, suggested that a copy of the resolution be sent to every member of the Legislative Council: this was agreed. The Legislative Council realised that a reduction was inevitable but considered three votes to be too low. ${ }^{201}$ On behalf of the Corporation W.B. Propsting moved that five votes be accepted and this was passed. When Propsting was first elected to the Legislative Council in 1905, wrote the Daily Post, he supported adult suffrage for municipal elections on sanitary grounds but the then "leader of Liberal Democracy in Tasmania" lost his fight and his liberalism on entering the Upper House. 202

The House of Assembly refused to accept the Council's amendment. 203 As the unwavering stand of the Labor and Liberal dominated House of Assembly jeopardised the passage of the much desired Greater Hobart provisions of the Bill, the Legislative Council gave way. It agreed to a four vote maximum for plural voters owning property at $£ 150$ and over and that ratepayers rated at $£ 50$ could become an alderman, but insisted that the clause allowing

201. Ibid 11 December 1913.

202. D.P. 13 December 1913.

203. M. 13 December 1913. 
female ratepayers to stand for alderman be deleted. 204 This was accepted by the House of Assembly on a motion by Elliott Lewis. The Mercury was not sorry to see plural voting reduced. Plural voting left the Corporation "open to attack" as it was a symbol that the city was managed in the interests of the few. 205 The city's progress over the last decade proved that this was no longer the case and at elections "had all the voters possessed single votes only", the outcome would have been much the same. - In any event, after over 20 years of agitation, the labours of municipal reformers had at last borne fruit and the constitution of the Hobart Corporation had been made more democratic.

In various ways, then, there developed in Hobart over this generation a real interest in the politıcal culture of municipal reform. The concern for health was an important part of this culture. The sanitary improvement of the city was held by Liberal and later Labor reformers to be impeded by the vested interests of the large property owners whose dominance on the Hobart Corporation was assured by restrictive property qualificatıons. Hence constitutional reform of the Council preoccupied the minds of reformers who were inspired by a vision of Hobart as a model city run efficiently in the interests of all residents, wealthy or poor. Committed to environmental control, and increasingly to the acquisition of public utilities, they wanted to ensure that human effort was properly directed towards overcoming the disease generating blots on nature's remarkable landscape. Assisted by a growth in clvic pride and post-federation prosperity they achieved much: in 1914 Hobart was, in many respects, a more pleasant and

204. Ibid; Hobart Corporatıon Act 1913 clauses 36 and 37. 205. Ibid 30 January 1914. 
healthy place in which to live than in 1885. It is time now to consider in detail the major public health problems and the obstacles that confronted attempts to conquer them. 


\section{CHAPTER SEVEN}

\section{THE CITY HEALTH DEPARTMENT}

The promotion of Australia in Great Britain as a continent with a healthy climate and pure environment free from disease was, argues Powell, "a vital component in the processes of migration and settlement". 1 The image of Hobart as the Sanatorium of the Australian colonies and a mecca for those in search of health originated soon after the city was settled. Faced with challenges from other colonial cities making similar claims the image had to be preserved at all costs either by denying their were public health problems or trying to overcome the problems that existed. The natural advantages of climate and topography were often used as an excuse that no sanitary reform was necessary: disease was a temporary aberration that nature would conquer. Suggestions that Hobart had a serious sanitary problem were quickly rejected and the accusers denounced for traducing the good name of the city. Municipal elections were the best time to seek promises from aldermanıc candidates but they were held at the beginning of the tourist season and, wrote the Tasmanian News, "if an honest attempt be made to point out the most serious failures of the Corporation - where connected with water supply, drainage and sanitary matters generally, the critic is immediately charged with defaming the City and injuring the season". 2

1. J.M. Powe11, "Medical Promotion and the Consumptive Immigrant to Australia", Geographıcal Reviex; v.63, 1973, p.449. For an overview of the relationship between environment and disease in Australia see B. Gandevia, "The Medico-Historical Significance of Young and Developing Countries, Illustrated by Australian Experience", in E. Clarke (ed.) Modern Methods in the History of Medicine, (London, 1971), p. $\overline{75-98 . ~}$

2. T.N. 6 December 1897. 
Defenders came from various sections of society. The Mercury, for example, was not blind to Hobart's sanitary deficiencies and often advocated sanitary measures but it was careful not to exaggerate. Exaggeration would affect immigration and stop the tourists, who Injected much needed money into the economy, from visiting the city in summer. ${ }^{3}$ Morris has shown the importance of tourism to Hobart from the late 1880 s and chartered the growth of a movement to develop and publicize Hobart's attractions but tended to overlook the movement's concern to curtail epıdemics. 4 The Mercury attempted to underplay the severity of epidemics. In 1891 it wrote:

The impression has been allowed to go abroad that Hobart is more unhealthy than other places, whereas the fact is that it is one of the healthiest cities in the world, as we have shown time after time from statistics which cannot be so much questioned. 5

Visitors, claimed the Mercury, preferred Launceston to Hobart In the mistaken belief that it was less troubled by disease but statistics proved "the comparative superiority" of Hobart. This myth had arisen because Launceston residents made less fuss of disease than Hobart residents and pushed their city forward as a model of sanitary perfection. Diseases, in particular typhoid, had aroused "unwarranted fears" but Hobart, despite "all its faults and all the neglect of its local authorities, .... may safely

\footnotetext{
3. M. 3 September 1891.

4. C.A. Morris, "In pursuit of the Travelling Man: A Study of Tasmanian Tourism to 1905" unpublished B.A. Hons. Thesis, University of Tasmania, 1974.

5. M. 3 September 1891 .
} 
be said to be a place whither those who desire a healthy and agreeable refuge from the sumer heat of Australia may come ...."6 Aldermen contributed to Hobart's image. John Watchorn regarded Hobart as "the best of cities in the best of climates" but he paid for his deception. ${ }^{7}$ In December 1896 Watchorn, after 21 years of aldermanic service, the last three as Mayor, was not re-elected: the sanitary movement united against him because of his refusal to admit to sanitary reform. ${ }^{8}$ Even men of science defended Hobart's reputation. Papers read to the Royal Society by the respected Government Statistician R.M. Johnston in 1887 and 1896 were pralsed for statistically proving that Hobart was "pre-eminently one of the most health cities in the world". 9 Johnston stressed the large number of old people in the city's population compared with other cities and argued that this was an Important indication of health. Enthusiasts for sanitary reform were, he said, "prone to exaggeration": he was inclined to attribute epidemics "to unknown or obscure cosmical influences" and underplayed, but did not discount, the benefits of sanitary measures. 10

Statistics indicating "the comparative superiority" of Hobart did not go uncontested. Discussion after Johnston's paper resulted

6. Ibid

7. Ibid 10 December 1895.

8. T.N. 11 December 1896.

9. R.M. Johnston, "The Health of Hobart", P.P.R.S.T., 1896, p.13; R.M. Johnston, "How far can the General Death Rate for all Ages be Relied Upon as a Comparative Index of the Health or Sanitary Condition of Any Community", P.P.R.S.T., 1887, p.13-25.

10. Johnston, "How Far Can", p.28; see also R.M. Johnston, "Remarks on the Observed Periodicity of Death-Rate, with Suggestions as to its Possible Relation with the Periodicity of Solar and Other Super-terrestial Phenomena", P.P.R.S.T., 1884, p. 236-39. 
in different statistics and interpretations being used to reveal Hobart's high death rate from preventable diseases, such as typhoid. Alfred Mault admitted that Johnston's figures on general death rates proved Hobart to be "one of the healthiest cities in the world" but was astonished by Johnston's implication that "better sanitary administration" had not reduced deaths in other Australian cities. ${ }^{11}$ Mault produced figures to show that typhoid was one disease that sanitary work could reduce and eliminate and Hobart, "though a very healthy place, may be made yet more healthy by the prevention of typhoid". The Tasmanian News agreed that tourists were "a considerable source of wealth" to the community but if Hobart was not to "Iose its character of being one of the best sanatoriums in the world" sanitary defects had to be overcome and not ignored. 12 It wrote: "Our population is increasing, our buildings are increasing and consequently there is greater need for urgent [sanitary] measures being adopted. Therefore it is an absolute necessity for the civic authorities to throw off their apathy". 13 Hobart had "splendid, almost unequalled natural advantages" but the death rate from typhoid was higher than in London with all its overcrowding and poverty. ${ }^{14}$ The Tasmanian News summed up the motivation of sanitary reformers: "the point to be considered is not, Does it compare favourably with .... [other cities] on the score of mortality? but, How much more healthy and pleasant can Hobart be made?"15 Thomas Bennison

11. Johnston, "The Health", op.cit., p.16-18.

12. T.N. 23 April 1887.

13. Ibid 17 January 1887.

14. Ibid 24 March 1898.

15. Ibid 11 February 1887. 
made a similar point when he said the aim of the Sanitary Association was to make Hobart "the sanatorium for all the colonies" and "a pattern city as regards cleanliness". 16

Of all sanitary reformers the Clipper was the most critical, calling the city "unsanitary Slobart" and blamed the lack of public interest in the City Council for allowing "the centre of the health resort of Australia .... to drift in the old smellful way". 17

It highlighted the form of censorship practiced by some newspapers. Every summer when disease was rife and tourists began to arrive "patriotism to the Almighty Dollar controls the lever of the great sup-Press" and talk of disease and sanitary reform was hushed up. ${ }^{18}$ Amidst this controversy, municipal government did play its role. The main instrument for so doing was the City Health officer.

Under the Public Health Act 1885 the aldermen of the Hobart Corporation became a Local Board of Health. The Health and Sanitary committee remained: it discussed sanitary problems and passed important subjects onto the whole Council as a Local Board of Health for decision. What was discussed was determined, to a large extent, by Dr. Edward Giblin, who continued to be parttime Health Officer for Hobart and suburbs. He was the only qualified member of the Sanitary department. In his reports to the Corporation Giblin recommended a particular remedy to sanitary problems but could not enforce it. Ultimate power, as in Launceston, rested with the aldermen to order the City Inspector

16. M. 9 February 1894.

17. C1. 5 December 1896.

18. Ibid 25 January 1896; 10 September, 26 March 1898. 
or the City Surveyor to carry out major recommendations. The. City Inspector William Mason, who also became Sanitary Inspector under the Health Act, did most of the house to house inspection and issued notices to abate nuisances. The creation of a Central Board of Health affected Giblin and Mason in the sense that cltizens had an alternative body to which complaints could be sent if the Corporation was lax in its work: this increasingly happened. In March 1887 new by-laws, prepared by the Local Board of Health were gazetted to regulate the removal of nightsoil and refuse, the drainage of buildings, the pollution of water and the condition of dairies. 19

Giblin's duties were curtailed in July 1887 when the Government decided, as an economy cut, to stop payıng him $\lesssim 100$ per annum to act as Health Officer for the suburbs of New Town, Wellington and Queenborough. 20 He protested because it would be useless to attain a satisfactory sanitary standard in the city if the suburbs were rampant with disease: the Government would not budge. As a part-time Health Officer Giblin could not properly supervise the work of his subordinates and Mason had a free hand. In July 1889 Mason accused the Assistant City Inspector George Smale of not doing enough work and recommended his dismıssal. 21 According to the l'asmanian News Smale was a very efficient worker and was pointing out sanitary defects that Mason should have dealt with long before: Mason saw Smale as a threat to his position. 22 An influential petition, including the signature of the Chief Justice, supported Smale, describing him as an able worker.

19. Hobart Gazette 8 March 1887, p.469-70.

20. M. 16 August 1887.

21. Ibid 4 July 1889.

22. T.N. 2 July 1889. 
Although some aldermen also spoke highly of Smale, the Council, asserting the right to determine the fate of its employees, backed up Mason and Smale was replaced. If Giblin had been a full-time Health Officer he could have assessed who was the more efficient worker of the two. Giblin had built up "one of the most extensive and best practices" in the city and was probably reluctant to give it up and in any event aldermen were unwilling to pay for the services of a full-time Health Officer. ${ }^{23}$ Later, in May 1891, Giblin was elected to the House of Assembly and this limited even more the time he had left for sanitary matters. ${ }^{24}$ Mason assumed more importance in these circumstances and the success of sanitary measures rested heavily on his shoulders.

The positions of Health Officer and City Inspector received greater probing soon after the formation of the Women's Sanitary Association. In July 1892 it advocated the appointment of an independent Health officer, who would devote all his time to the job, who held a diploma of the London Medical Board of Health, and who had "practical experience" in working under it. 25 The " Health Officer should have "full executive power with an adequate staff of inspectors working under him". Thus the Health Officer would be the head of his own department and not an isolated official. Reports were given to the Council describing the duties of Health Officers in London and New York. Giblin, as we know, was not full-time Health Officer, nor did he possess a diploma of public health. For the proposal to be accepted Giblin would have to

23. M. 30 December, 1895.

24. S. \& B. Bennett, Biographical Register of the Tasmanian Parliament 1851-1960, (Canberra, 1980), p.65

25. M. $13 \mathrm{July} 1892$. 
be replaced. If the Women's Sanitary Association's proposal was not a personal slight on Giblin, he regarded it as one. When the Council discussed the matter Giblin said it was generally thought that "the movement was a deliberate attempt to oust him from his position". 26 Aldermen defended Giblin. George Davies, a friend and fellow Freemason, praised Giblin's abilities and criticised the women for their "dictatorial spirit". Mayor Thomas Reynolds claimed the Council could not afford to adopt the proposal. There was no doubt that re-organisation of the Health department along the lines suggested by the Women's Sanitary Association was necessary but Giblin's contribution to public health reform should not be underestimated. It was "greatly in consequence of his endeavours" that the Public Health Act 1885 was passed and he was one of the leaders in the campaign for a metropolitan drainage scheme. 27 It was the parsimony of the Council that forced him to maintain a private practice and prevented him from giving proper attention to sanitary matters. The Sanitary Associations continued to complain of the way in which sanitary measures were administered but in December 1895 Giblin's sudden death from sunstroke gave aldermen an opportunity to review the organization of the Health department. 28

Davies, no longer bound by friendship to Giblin, led the debate and argued for a system identical to that advocated by the Women's Sanitary Association. 29 He wanted "an officer thoroughly competent to undertake the management of their sanitary affairs

26. Ibid $30 \mathrm{July} 1892$.

27. see the CentralBoard of Health Annual Report 1895 T.P.P. $1896 / 42$.

28. M. 30December 1895 .

29. Ibid 7 January 1896. 
in addition to the duties of Officer of Health": the person would work in a full-time capacity and should have sanitary and medical diplomas. Subsequently a report of the Health and Sanitary committee recommended the amalgamation of the positions of Sanitary Inspector and Health Officer and that the new officer devote "the whole of hıs time" to his duties at a salary of at least $£ 350$ a year. ${ }^{30}$ It was hoped to secure a doctor and bacteriologist with a sanitary diploma. As Bradley and Seabrook were two of the members of the Health and Sanitary committee the recommendation was not unexpected. In the past the Sanitary Inspector was paid 208 and Giblin, including expenses, £168. Thus the new position would save $\$ 26$, which appealed to the economy conscious aldermen and the report was adopted. Two doctors applied: Dr. E.P. Vines and Dr. Gregory Sprott. 31 Sprott was chosen. Born in 1863 In Scotland, Sprott was educated at the University of Glasgow, obtaining medical qualifications and a diploma of public health. 32 He was a Fellow of the Royal Institute of Public Health in London and practiced in India, America and England before settling in ' Ulverstone, in Northern Tasmania, in 1890 because of declining health. In December 1893 he arrived in Hobart to take up an appointment as House Surgeon at the General Hospital. Thus Sprott's qualificatıons and experience were impressive. His appointment was welcomed. The Mercury regarded Sprott as "a man in whom the citizens may have every confidence", particularly as he held a diploma of public health. 33 Sprott began work on 3 March and

30. Ibid 21 January 1896.

31. Ibid 18 February 1896.

32. Cyclopedia of Tasmania, (Hobart, 1900), v.1, p.193.

33. M. 12 March 1896. 


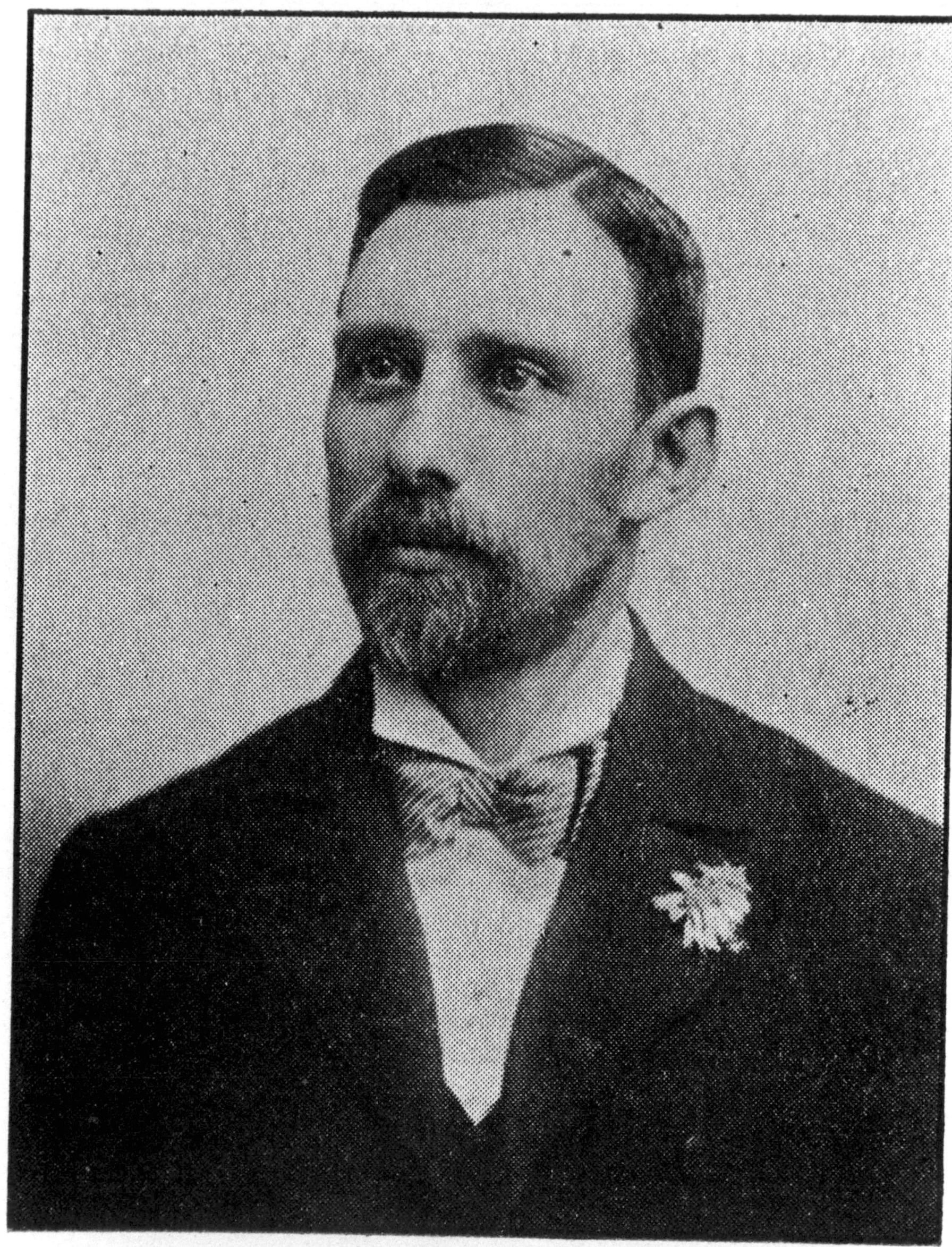

R. MCGUFFIE \& CO.,

HOBART.

Dr. G. SprotT. 
Mason, after 29 years service, was persuaded to retire. ${ }^{34}$ Thus sanitary work was elevated to a new level of importance and was in the hands of an expert, educated in the science of sanitation. 35 In November 1896 Sprott was one of the founders of the medical section of the Royal Society of Tasmania: leading doctors became members and the section occasionally offered views on public health matters. 36

Sprott's first annual report testified to his diligence and ability. 37 He very thoroughly discussed every aspect of public health and suggested numerous sanitary improvements. More atteniion was given to the inspection of milkshops, dairies, butchérshops, bakehouses and workrooms. He was "ably assisted" by Sergeant Edward Butterworth, the new City Inspector, who energetically employed the legal powers at his disposal to curb nuisances. Butterworth served 578 notices and orders compared with 332 in 1895. The Mercury, after perusing the report, concluded that there was "new life in what used to be a mere perfunctory piece of business and .... a more vigorous state of affairs has been inaugurated". 38 The report showed that there was "a great deal to do, a veritable Augean Stable yet to be cleaned", but the future looked bright. In 1896 revised by-laws were passed and in 1897 Sprott was appointed honorary bacteriologist and pathologist at the Hobart General Hospital, enabling him to diagnose suspicious cases of infectious diseases at an early stage and stop the disease spreading. 39

34. Ibid 10 March 1896.

35. see B.G. Rosenkrantz, "Cart Before Horse: Theory, Practice and Professional Image in American Public Health 1870-1920", Journal of the History of Medicine and Allied Sciences, v.29, 1974, p.55-73 for the rise of doctors to this pre-eminent position in American public health.

36. P.P.R.S.T., 1896, p.xxii.

37. M. 8 December 1896.

38. Ibid 9 December 1896.

39. Hobart Gazette 14 January 1896, p.223-6; MCC 16/48 12 January 1897; W.G. Rimmer, Portrait of a Hospital: The Royal Hobart, (Hobart, 1981), p.160. 
In May 1897 the Central Board 'of Health thought the suburbs surrounding Hobart and Launceston needed Health Officers. 40 Dr. E.J. Crouch described the suburbs as "outposts of the cities and were left unguarded". In August the Hobart Corporation was asked by the Local Boards of Health of Queenborough and Rural Queenborough to allow Sprott to act as Health Officer but the request was denied on the grounds that it would interfere with Sprott's work in the city. 41 Two months later James Gregory, chairman of the Queenborough Board, asked the Council to reconsider. ${ }^{42}$ The Queenborough Board, guided by Gregory, earnt a well-deserved name for attention to sanitary matters in the 1890s and securing Sprott's services would lead to further progress. The Health and Sanitary committee found many advantages to the city of Sprott inquiring into cases of infectious diseases and advising the Queenborough Board "on matters requiring the opinion of a medical expert" to assist the suburb's Sanitary Inspector. Hobart received milk and other dairy produce from the suburbs and dairies needed careful supervision by a medical expert: also children came from the suburbs to city schools and could spread infection. John Bradley grasped the essential point when he noted that "the city and suburbs was one, the drainage was intermixed, and the sanitary state of the metropolitan district was a matter of common concern to them all". This argument had undeniable force and Gregory's request was granted. Davies believed that already Sprott "had done more for the Health of Hobart than any other sanitary officer" during the 15 years Davies had been an alderman and Queen-

40. M. 19 May 1897.

41. Ibid 10 August 1897.

42. Ibid 12 October 1897. 
borough would benefit from Sprott's advice. 43

Despite the progress made in sanitary matters under Sprott, work was hampered by the failure or refusal of sanitary officials to follow his recommendations. In February 1898 Alderman Samue1 Benjamin asked if it was true that, of the 195 cases of nuisances reported on by Sprott in the 12 months to November 30, only 36 , or 18 percent, were attended to. ${ }^{44}$ The City Surveyor Robert Milles, who was also Director of Waterworks and city engineer, replied that "in one case only had written instructions been given by the Council to his office" to remove nuisances, although "many cases" were attended to by "verbal arrangement" with the Health department but he stressed that he could not cope with an increasing workload without additional assistance. ${ }^{45}$ This explanation indicated a serious gap in sanitary administration. Sprott could report on threats to health but, like his predecessor Giblin, did not have the power to ensure his recommendations were carried out. When a single house was involved and the work was "comparatively trivial", it was usually done. ${ }^{46}$ When a block of houses required drainage and involved "the responsibilities of various owners", levels had to be taken, the line of drainage defined and working plans prepared, all of which came under the jurisdiction of the City Surveyor, whose time was consumed with other duties and the work was postponed. The Mercury labelled this "criminal apathy" and called for the appointment of an Assistant City Surveyor

43. Ibid 10 August 1897 .

44. Ibid 8, 15February 1898.

45. MCC 16/56/5. For Milles see Cyclopedia of Tasmania, op.cit., v.1, p.192-3.

46. M. 25 March 1898. 
"specially deputed to attend to health matters". 47

Benjamin was astounded that Sprott's recommendations were treated in such a "cumbersome and slow" way, resulting in "much undesirable delay". 48 He moved that Sprott be empowered to dea1 with all sanitary matters "without reference to the Surveyor's Department" and to have urgent works carried out "without first consulting the Council". The motion was negatived with little debate. It was inconceivable to the majority of aldermen that a Corporation officer could act without their assent, but if advances were to be made in public health Sprott needed the power that Benjamin's motion would have given him. Benjamin pressed for the acceptance of his motion but to no avail. ${ }^{49}$ Later in 1898 some attempt was made to grapple with the growing workload of the City Surveyor's department. William Brain was transferred from the Rates Office to the staff of the City Surveyor, "thereby materially expediting works coming under that department" from the Health and Waterworks departments. 50

In June 1899 Sprott began a private practice but remained as Health Officer on a part-time basis at a salary of $\equiv 150$ a year. 51 Brain was relieved of his duties in the Waterworks department to become Engineering Inspector and Assistant Health Officer at a salary of $£ 200$. Edward Butterworth remained City Inspector, with one assistant. That the re-organization was a failure was exposed by the Royal Commission on the Municipal Government of Hobart and the Suburbs. 52 The re-organization had created "divided

47. Ibid.

48. Ibid 1, 24 March 1898.

49. Ibid 5 April 1898.

50. Ibid 6 December 1898.

51. Ibid 6 June, 5 December 1899.

52. T.P.P. $1901 / 5$. 
responsibility" within the Health department. Sprott, as Health Officer, was "the official head" but Brain, as Engineering Inspector, was "the actual head". Sprott had "no thorough or absolute authority in the administration of the department he nominally controls". Brain spent much of his time preparing and supervising plans for new buildings leaving "little leisure for other duties". He was in charge of Butterworth and his assistant. Butterworth, apart from his sanitary duties, was Bailiff, Inspector of Weights and Measures, Inspector under the Impounding Act, in charge of dog licences, milk licences, licences issued to cab-drivers, stagecoaches and drays. Butterworth admitted that he did not have enough time to "properly" carry out his sanitary duties. To assist with sanitary inspection constables on duty in different sections of Hobart made "a regular visitation of premises, the results of which is conveyed in a weekly report to the Town Clerk". Police inspection was adequate but, said Brain, the Health department lacked the staff "to cope with all the nuisances that are reported by the police". Defective gutters could be attended to by Brain or the City Surveyor, who was in charge of a different department. The constables were under the control of the Commissioner of Police, who was not a Corporation employee and who could withdraw constables for other purposes whenever he liked. The Royal Commission summed up sanitary administration: in Hobart, where there is no modern system of deep drainage, where the Corporation does not undertake the regular removal of house garbage on an effective system, and where the gutters, very infrequently flushed, are in many cases dangerous to public health, the duties of 
inspection, if properly fulfilled by the health

authorities, could not fail to be very heavy, and could not possibly be carried out by a small department under divided control and otherwise imperfectly administered. 53

Sanitary administration in the suburbs, found the Royal Commission, was more disorganised and undermanned than in Hobart: Queenborough was the only suburb with some kind of sanitary system. The strictures went unheeded. The only notable addition to the sanitary inspectorship was Ethel Keach's appointment as female inspector in May 1903. 54 The reason for her appointment will be examined in a later chapter.

In July 1903 Sprott resigned as Health Officer apparently because of his growing private practice. ${ }^{55}$ This resulted in another re-organization of the Health department. The Waterworks and City Surveyor's departments were amalgamated with the Health department. 56 Sprott's resignation re-opened the debate on whether a full-time Health Officer was required and until a decision was made Dr. Robert Willmot was made Acting Health Officer on 8 August. 57 "Health", writing in the Mercury, was in no doubt that the Health Officer should not maintain a private practice because if would cloud his judgement. 58 "Health" asked: "Can anyone look with fair eyes and impartial mind on an insanitary building that requires demolition if its owner, agent or trustee, is his patient?" The

53. Ibid, p.xii.

54. T.N. 21 May 1903.

55. M. 7 July 1903.

56. Ibid 8 December 1903.

57. Ibid 22 September 1903.

58. Ibid $15 \mathrm{July} 1903$. 
Mercury argued that there was plenty of work for a full-time Health Officer, who should be well-paid. 59 It attributed the spread of smallpox in Launceston in September 1903 to "the failure to recognize the disease at an early stage", which would not have happened if the Launceston Corporation had employed a full-time Health Officer. On 1 October Aldermen Gould and Moore moved for the appointment of a full-time Health Officer at a salary of $£ 250.60$ Gould emphasised the duty of a Health Officer to visit every house to see that it was properly ventilated and fit to live in. He pointed to Hobart's growing importance as a health resort and argued that the Council should assist "in every reasonable way to facilitate the development of that great natural resource". His argument fell on deaf ears. The Council decided to appoint a part-time Health Officer.

Of the three applicants for the job Dr. Gerard Smith was the best qualified and was appointed. 61 He had spent 25 years practicing in London, where he was also an assistant Health Officer at Hackney and actively helped to prevent epldemics from spreading. He wás a member of the sanitary aid committee connected with the Mansion House scheme for housing the poor and was a lecturer under the Oxford House scheme for instructing the working classes on matters of personal and public health. 62 Smith used this experience to good effect, as will be seen, and was very candid in his reports on the sanitary needs of Hobart.

59. Ibid 1 October 1903.

60. Ibid 2 October 1903.

61. Ibid 27 October, 12 November 1903; T.N. 29 October 1903.

62. For references to the Mansion House scheme see G. Stedman Jones, Outcast London: A Study in the Relationship Between Classes in Victorlan Society, (Harmondsworth, 1976). 


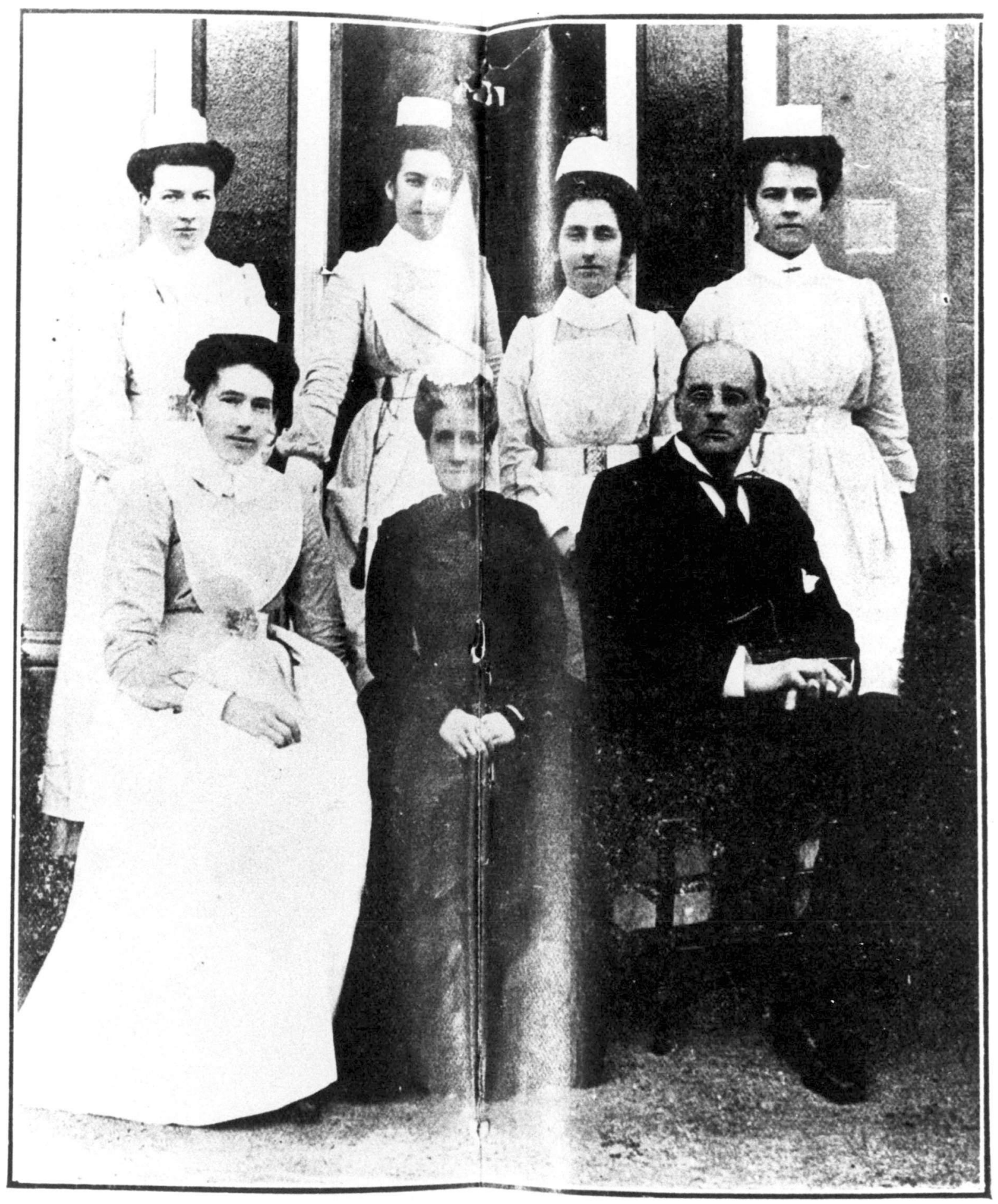

DR. GERARD SMITH 
When the Central Board of Health was notified of Smlth's appointment, it refused, on the casting vote of the President Dr. John McCall, to confirm it and asked the Council to reconsider. ${ }^{63}$ The Council stood firm and asked for reasons why Smith should not be appointed. McCall was alleged to have voted against Smith because he was a newcomer to the State without local knowledge. One correspondent thought this an advantage and pointed out that Dr. Elkington, recently appointed Chief Health Officer of the newly created Department of Public Health, was chosen because he was a stranger and was less likely to be influenced by local interest groups. ${ }^{64}$ The real objection was Smith's homoeopathic convictions. On 24 November McCall admitted that the decisive reason for not ratifying Smith's appointment was a resolution of the medical section of the Royal Society, comprised of allopaths, that the interests of public health would not be served by a Health Officer who practiced homoeopathy. 65 billmot had resigned by December and Smith had taken up "the required duties". 66 The Central Board of Health was legislated out of existence by the Public Health Act 1903. The new Department of Public Health recognised Smith's extensive experience and did not block his appointment.

That this was the right decision was soon demonstrated. It was Smith's goading, as we shall see, that resulted in a vigorous inspection and demolition of old and insanitary housing. He made a number of reports on the condition of premises occupied

63. M. 12 November 1903 .

64. Ibid 16 November 1903 letter by Oscar Kalbéell.

65. Ibid 25 November 1903.

66. Ibid 8 December 1903. 
by cowkeepers and purveyors of milk. 67 By December "a large number" of dairies and cowsheds were brought "into better conformity with the Corporation by-laws" that had been passed in 1899: milk was much cleaner and this had "a good effect" on "the infant mortality" in the summer months. ${ }^{68}$ Dairies could only gradually be improved because "most of the premises are so old". 69 Smith received cheering encomiums for his work. That 1904 was a year of achievement in Hobart's sanitary administration, wrote Mayor Bennison, was not due to the powers granted by the Public Health Act 1903 but to Smith, who was "an excellent officer". 70 He carried out his duties "in a highly successful and tactful way; and this is shown by the fact that although many unpleasant duties have been carried out by him, in no case has there been any difficulty in having his orders and recommendations put into effect". Supported by the Health committee and, by now, the majority of aldermen, Smith showed what a Health Officer could achieve. Bennison was not alone in his assessment. The Mercury thought that "Undoubtedly much has been accomplished" since Smith was appointed. 71 Elkington also praised Smith. ${ }^{72}$ By giving lectures and providing advice to members of the Women's Health Association on numerous occasıons he earnt its approval: the Women's Health Association felt that "Hobart was fortunate in possessing such a thoroughly able and conscientious City Health officer". 73

67. for examples see Ibld 24 May, 14 June 1904; T.N. 21 April 1904. 68. M. 6 December 1904. See the protest by 'Danie1' against the enforcement of the by-law's T.N. 4 July 1904 and Smith's reply T.N. 5 July 1905.

69. M. 15 August 1905.

70. Ibid 6 December 1904.

71. Ibid 8 September 1904.

72. Ibid 6 September 1904.

73. Ibid 17 April 1905. 
Smith was always prepared to justify his actions or correct misinformed impressions of the work of the Health department. In July 1906 an editorial in the Mercury complained that the Health department was understaffed and implied that the annual inspection was the only one carried out. 74 Smith's rejoinder was that inspections were "continuous and employ the whole time of the staff". 75 Detailed weekly reports were submitted to the Health committee and notices were frequently served. In addition to the routine inspections of the two inspectors, Smith inspected "all special cases" and visited, with the City Surveyor, "all houses which require special repairs or demolition". He also made weekly analyses of milk. Smith proudly concluded that compared with the sanitary condition of Hobart four years ago, "the general change for the better is extremely marked". Believing in "a uniform system of public health administration under one health officer for the city and suburbs", he offered his services to the local boards surrounding Hobart, but only Wellington and Mt. Stuart employed him. ${ }^{76}$ Smith's tenure of office ended in January 1907 when he resigned to return to England. 77

There were four applicants for Smith's job: Sprott was appointed and took up duties on 1 February. ${ }^{78}$ The decision could not be faulted as Sprott had done good work when previously Health Officer and with aldermanic support could be expected to consolidate the Improvements achieved by Smith. He was still a parttime Health Officer and saw a need for an extra sanitary inspector:

74. $\quad$ Ibid 18 July 1906.
75. Ibid 24 July 1906.
76. T.N. 26 April 1905 letter by Smith.
77. M. 8 January 1907.
78. $\quad$ Ibid 22 January, 3 March 1907.


this would result in "a more rigid inspection of all the properties in the city" and enable more attention to be given to "the important matter of food adulteration". 79 In July 1907 it was decided to appoint another inspector at a salary of $£ 200.80$ Applicants were required to be "fully qualified" and possess a certificate "from some recognised institute". From 30 applicants F.G. Tuck was appointed. 81 Tuck, who had been chief sanitary inspector of New Town in Sydney, was exceptionally wellqualified. He was an Associate of the Royal Sanitary Institute, London, holding their certificates for sanitary science and inspector of nuisances. He also held certificates from the Sydney Technical College in sanitary engineering, building construction and constructional drawing, possessed five certificates in the theory and practice of sanitary plumbing and studied veterinary science but did not sit for the examinations. Tuck's appointment reflected an awareness on the part of aldermen that the days of untrained inspectors were over. From now on only qualified inspectors well versed in sanitary principles were appointed and to some extent compensated for Sprott being a parttime Health Officer.

To assist in the fight against infectious diseases, two additions were made to the Health department. During his first period as Health Officer Sprott had often urged that the Council build an infectious diseases hospital. 82 This became particularly

79. Ibid 6 August 1907.

80. Ibid $23 \mathrm{July} 1907$.

81. Ibid 20August, 3 September 1907, 3 March 1908.

82. For a full account of his views see G. Sprott, "Isolation of Infectious Diseases by Local Authorities", Intercolonial Medical Congress of Australasıa, 1899, 5th session, p.44657. 
necessary in 1898-9 when the Hobart General Hospital refused to admit scarlet fever cases and later diphtheria cases: this stand was maintained despite many representations. ${ }^{83}$ Parliament voted $£ 5,000$ towards the cost of an infectious dıseases hospita1 but objections to various sites prevented construction. Finally in May 1908, after an appeal by Sprott, a site known as Vaucluse, on the corner of Macquarie and Gore Streets was "prepared for the reception and treatment of diphtheria cases unable to gain admission to the General Hospital". 84 Sprott attended to cases admitted to Vaucluse. The building was not entirely suited to be an infectious diseases hospital and the cost of treatment, especially of cases from outside Hobart, became a contentious issue. Some form of Government Involvement was unavoidable. In June 1911 the Chief Secretary Dr. G.S. Butler drew up a scheme which won general acceptance. 85 The Government proposed to build a new infectious diseases hospital on the vaucluse site and be responsible for the upkeep of all buildıngs. The City Council would control the hospital and the Government would pay half the cost of fuel, light and salaries, and build temporary wards if epidemics rendered the accommodation insufficient. Butler wanted to encourage the local treatment of infectious cases: thus the Government undertook to contribute towards the cost of building smaller isolation hospitals throughout Tasmania and the cost of treatment. Construction of the new Vaucluse hospital was begun in late 1913 but was not ready for the reception of patients by 1914.86

83. Rimmer, op.cit., p.174, 179-80.

84. M. 2, 5 May 1908.

85. T.N. 26 June 1911; M. 27 June 1911.

86. M. 8 December 1914 . 
The other addition to the Health department's resources was the purchase of a Washington Lyne disinfector in $1909 .^{87}$ It was used to disinfect the clothing of consumptives and other infectious diseases cases. The prevention of consumption or tuberculosis, which caused more deaths than any other infectious disease, was of special interest to Sprott. 88 Much could be done to lower the incidence of tuberculosis by the general improvement of sanitary conditions, analysing milk and meat and the enforcement of by-laws against spitting but isolation of consumptive patients from other infectious cases was essential. 89 Philanthropic citizens banded together to raise funds for a consumptive sanatorium, which was opened on 5 December 1906.90 It was called the New Town Consumptive Sanatorium and was the only one in Southern Tasmania. Accommodation was limited and, especially after the compulsory notification of consumption began on $1 \mathrm{July} 1909$, was very inadequate. In his annual report of 1909 Sprott suggested that the Council, with the help of a State subsidy, provide free treatment in "a well-equipped sanatorium", including treatment. for advanced cases, which were excluded from the New Town sanatorium. 91 The patients would, for two or three months, be instructed in the precautions to take against the spread of the disease. While in Europe in 1912 Sprott made a study of municipal involvement in the treatment of consumption. 92 He was impressed with

87. Ibid 7 December 1909.

88. see G. Sprott, "Tuberculosis", P.P.R.S.T., 1896, p.45-68.

89. M. 6 August 1907, 27 May 1914.

90. Ibid 6 December 1906; T.P.P. 1907/29, p.9.

91. Ibid 19 April 1910.

92. Ibid 26 November 1912; LA 26/4/2 p.339-40. 
the thorough methods employed: as well as sanatoria for early cases and hospitals for advanced cases, dispensaries were also important in the treatment of the disease. Despite Sprott's prodding the Hobart Corporation did not involve itself in the treatment of tuberculosis, regarding it as the responsibility of the State, but, as the opportunity arose, information was given to householders on "the needs of isolation of patients, disinfection of clothing, sputum etc."

The amalgamation of Wellington, Glebe Town, Mt. Stuart and Queenborough increased the workload of the Health department but the staff was not increased. The Women's Health Association felt it was time to employ a full-tıme Health Officer and in May 1914 asked the Council to consider the matter. ${ }^{93}$ The Health committee recommended that a decision be postponed until negotiations with New Town, Bellerive and Lindisfarne, about a proposed amalgamation, were completed. Alice O'Shea-Petersen, who in 1914 gained a Health Inspector's certificate after passing examinations of the Royal Sanitary Institute, claimed she was responsible for the Women's Health Association's suggestions. 94 Writing to both the Mercury and the Daily Post, she pointed out that Perth and Hobart were the only cities in the Commonwealth, with a population of 30,000 , that did not have a full-time Health Officer. 95 She denied that Sprott's ability was being questioned but challenged the Mayor to publish a list of jobs held by Sprott, the money he was paid and the honorary positions he held.

93. Ibid 12 May 1914.

94. Ibid 14 May 1914; D.P. 14 May 1914; T.P.P. $1915 / 34$ p.7. 95. Ibid. 
Mayor Meagher did not accept the challenge but "In The Know", a correspondent to the Daily Post, did. ${ }^{96}$ The list was staggering. Sprott was Health Officer of Hobart, Queenborough, New Town and Kingborough; medical officer in attendance at Vaucluse; Federal quarantıne officer; and received a fee for the inspection of hotels. For these appointments Sprott was paid about $£ 675$ per annum, which was more than McClintock, the new Chief Health Officer, who had no private practice. Sprott had "a large club and private practice" but was also police surgeon; railway medical officer; surgeon to Jones and Company's employees; medical officer to the Unzon and Huddart Parker Steamship Companies; an examining officer to the A.M.P. Society; one of four honorary medical officers to the Hobart General Hospital; and an honorary consulting surgeon to the Alexandra Hospital for women. Given this heavy burden, Frances Edwards, a member of the komen's Health Association, was right to wonder what tzme Sprott had left to spend on "preventive work". 97

In June the Women's Health Association pressed the Council to reconsider the appointment of a full-time Health Officer. 98 The previous decision was reaffirmed. Meagher said extra inspectors were needed more than a full-time Health Officer. However the issue could not be easily shaken off as Sprott came under sustained attack. Writing to the Mercury "Ratepayer", after listing Sprott's multifarious jobs, starkly asked "Does the Mayor feel satisfied that the health of the city is being adequately cared for by a gentleman who can have only a very few hours a

96. D.P. 19 May 1914.

97. M. 22 May 1914.

98. Ibid 10 June 1914. 
week to devote to his duties?" 99 "Ratepayer" even accused Sprott of "hurriedly" resigning his appointment in 1903 when smallpox appeared in Launceston "because he was afraid of being called upon to devote all his time to dealing with that disease if it had spread to Hobart". Another correspondent "Dione" pointed out the possible conflict of interests that could arise between Sprott's public and private appointments. ${ }^{100}$ Sprott inspected factories but was employed by a factory owner; he was a quarantine officer but was employed by steamship companies; he was paid as Health Officer by the Council to prevent disease but the Council also paid him "a fee or a bonus" for each patient he treated at Vaucluse. For fear of spreading infection attendants and nurses at Vaucluse were discouraged from mixing too much with "the general public, particularly children". By treating cases at Vaucluse Sprott could spread infection to his private patients and surgica1 cases. By maintaining a private practice, "Dione" endeù, Sprott was "merely a nominal guardian of the public health". The campaign for a full-time Health Officer was bolstered by the intervention of the Daily Post, which enlivened the municipal elections of 1914. In a series of stinging editorials it demanded that Sprott state publicly whether he was prepared to forgo his other appointments and become a full-time Health Officer at "a reasonable salary". 101 It wrote "We will support Dr. Sprott as Full Time Officer. But it is full time officer, or go ....": it was "the system we object to, not the man", because it allowed conflict of interest. 102 The Women's Health Association openly

99. Ibid 13 June 1914.

100. Ibid 22 June 1914.

101. D.P. 30 November 1914.

102. Ibid 10 December 1914. 
congratulated the Daily Post for "successfully arousing a healthy public interest in the municipal affairs of the city, more particularly in regard to the urgent need for .... a whole-time medical officer". 103 The Daily Post claimed that two successful candidates J.G. Shields and T. Am ott supported a full-time Health Officer but membership of the Health committee was arranged so that such aldermen were not on it. ${ }^{104}$ It intended to continue the attack in 1915.

Sprott, who in 1911 was elected first chairman of the Tasmanian branch of the British Medical Association and was a pillar of the medical establishment, kept a discreet silence. 105 He made no mention of the controversy in his annual report of 1914 and simply made a plea for more inspectors. ${ }^{106}$ The Chief Inspector Tuck was assisted by Inspectors Wise and Plane in the inspection of all aspects of food supply, factories, houses and disinfections. The lady inspector Ethel Keach resigned in 1914 and was replaced by a male, Inspector Wilkins, soon to take up his duties. Sprott wanted another male inspector, who, with Wilkins, would concentrate on the "systematic inspection of houses", and a lady inspector with nursing qualifications, who could visit all infectious cases, especially those with tuberculosis, and shops and factories where women worked. Sprott became a full-time Health Officer in 1923 and retired in 1933: He then served four years as an alderman. 107 A man of tremendous energy and great dedication, Sprott made an outstanding contribution to improving the health of Hobart.

103. Ibid 19 December 1914.

104. Ibid 22 December 1914.

105. Rimmer, op.cit., p. 209.

106. M. 9 June 1915.

107. Ibid 15 August 1942. 
He acted as the conscience of the Hobart Corporation, pointing out deficiencies and never allowing aldermen to forget their sanitary responsibilities.

Despite the criticisms made by the Women's Health Association and the Daily Post, the success of sanitary administration in Hobart should not be underestimated. As was the case with Launceston fluctuations in the estimates of population statistics prevents complete accuracy: one way of measuring the success is to consider the general death rate. From 1888 to 1892 , years of sanitary neglect when epidemics were common, the average general death rate for the city of Hobart was about 19.85 per 1000 people and for the urban district, which included surrounding suburbs, about 21.62 per 1000. (Table 17) From 1910 to 1914 the average general death rate for the city was about 13.66 per 1000 and for the urban district about 13.90 per 1000 . Thus the average general death rate fell by almost a third. Infant mortality also dropped. From 1888 to 1892 the average death rate of infants under one year was 146 per 1000 births. (Table 18) From 1910 to 1914 when, as we know, registration of boarded-out infants was more stringent, it was about 88.88 per 1000 births. 108 A notable decline also occurred in the death rate from typhoid fever, as will be seen in the next chapter. The more vigilant attention given to sanitation by the Hobart Corporation, coupled with an improvement in the standard of living and possibly better hospital and medical treatment, as indicated by Rimmer, help to explain the lowered death rate. 109

108. As stated in Chapter 3 registration of women who took in children for payment was transferred from local authorities to the police by the Infant Life Protection Act 1907. For an early view of Sprott on the change see M. 9 April 1910.

109. Rimmer, op.cit., chapter 9. 
TABLE 17 : HOBART'S DEATH RATE PER 1000

\begin{tabular}{|c|c|c|c|}
\hline Year & City & Suburbs & District \\
\hline 1886 & - & - & 23.53 \\
\hline 1887 & - & - & 25.74 \\
\hline 1888 & 19.25 & 27.21 & 21.04 \\
\hline 1889 & 17.60 & 28.03 & 19.95 \\
\hline 1890 & 19.56 & 26.55 & 21.35 \\
\hline 1891 & 21.86 & 29.85 & 23.90 \\
\hline 1892 & 21.00 & 24.36 & 21.85 \\
\hline 1893 & 19.64 & 26.22 & 21.32 \\
\hline 1894 & 16.36 & 22.44 & 17.91 \\
\hline 1895 & 13.18 & 19.93 & 14.90 \\
\hline 1896 & 13.14 & 19.13 & 14.67 \\
\hline 1897 & 12.82 & 20.64 & 14.82 \\
\hline 1898 & 11.70 & 24.01 & 14.85 \\
\hline 1899 & 12.04 & 19.85 & 14.04 \\
\hline 1900 & 12.98 & 17.76 & 14.30 \\
\hline 1901 & 13.47 & 16.90 & 14.46 \\
\hline 1902 & 14.15 & 17.04 & 15.00 \\
\hline 1903 & 14.72 & 21.51 & 16.70 \\
\hline 1904 & 15.01 & 18.08 & 15.92 \\
\hline 1905 & 14.36 & 17.36 & 15.24 \\
\hline 1906 & 14.68 & 20.23 & 16.32 \\
\hline 1907 & 10.73 & 21.03 & 12.93 \\
\hline 1908 & 12.47 & 19.23 & 13.92 \\
\hline 1909 & 10.03 & 18.32 & 11.84 \\
\hline 1910 & 10.93 & 18.50 & 12.54 \\
\hline 1911 & 13.86 & 13.88 & 13.86 \\
\hline 1912 & 14.76 & 14.69 & 14.74 \\
\hline 1913 & 15.55 & 13.20 & 14.88 \\
\hline 1914 & 13.11 & 14.67 & 13.41 \\
\hline
\end{tabular}

Source: Statistics of Tasmania 
TABLE 18 : HOBART'S INFANT MORTALITY RATE

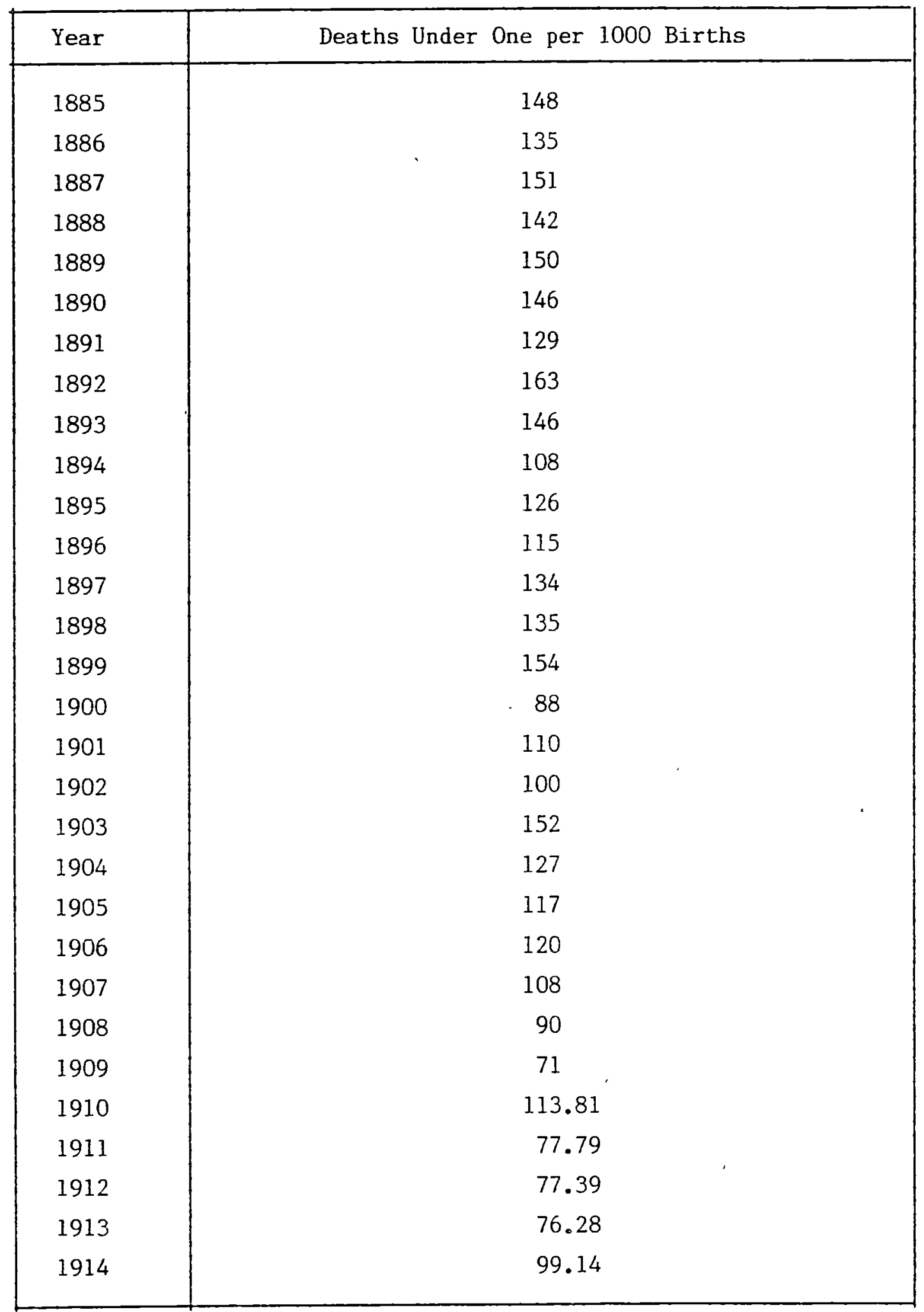

Source: Statistics of Tasmania, 1914, p.129 


\section{CHAPTER EIGHT}

\section{WASTES}

To control and dispose of the wastes generated by humans, it was written in Chapter Four, was the most fundamental sanitary duty of Corporations. Preventing the accumulation of wastes and cleaning up the environment was the first step towards reducing the incidence of infectious diseases. In this chapter the attempts of the Hobart Corporation to deal with refuse and nightsoil or excreta will be examined.

The Removal of Refuse

For Alfred Mault, Engineering Inspector to the Central Board of Health, the reduction of refuse in public streets and, more importantly, house yards and courts was "the crucial test of the effectiveness of the sanitary administration of a town". ${ }^{1}$ Judging by his 1886 report on its sanitary condition, Hobart failed the test. ${ }^{2}$ He found that a section in the centre of Hobart had some refuse removed by the scavenging department of the Council "under special rates and regulations" but "the smaller classes of houses" were "almost entirely unprovided with proper dustbins". When asked where they placed ashes and dust the answer was "Wherever we can", usually in backyards, streets and gutters. Animal and vegetable refuse was given to neighbours with pigs or cows: if "no such conveniences" were available the refuse was indiscriminately thrown away. Mault recommended that "the periodical removal of all dry refuse should be made part of the regular scavenging of the city; and the providing of proper receptacles by all owners or occupiers of houses made compulsory". All main

1. A. Mault, "Urban Sanitation", Australasian Association for the Advancement of Science. Report of 5th meeting, v.5, 1893, P.183.

2. T.P.P. $1886 / 47$. 
streets in the city should be swept at least twice weekly and other streets once a week. Refuse should be burnt and Mault recommended Fryer's Destructor as the best apparatus.

The press agreed that systematic removal of refuse was necessary in Hobart and this view strengthened from 1887 when the typhoid epidemics broke out. The miasmatic theory of disease posited a causal connection between filth and disease and the city had to be clean if disease was to be avoided. In 1887 the Mercury wrote that "the vegetable garbage, decaying animal matter, and other descriptions of household refuse, which may be found in heaps in numerous parts of the City, are quite as capable of disseminating disease as cesspits or ill-regulated closet-pans." 3 The public were not aware of the extent of the problem because residents kept the front of houses clean but refuse was "often allowed to accumulate for years" in backyards "where it was hidden from the general view". ${ }^{4}$ Epidemics forced the Council to clean up the city. Then, wrote the Tasmanian News, "a large batch of officials were sent out, half a dozen unfortunates are brought before the Mayor and fined, for allowing mounds of filth to accumulate .... As soon as the epidemic subsides the filth is again allowed to accumulate, the inspectors become invisible and the temporary measures adopted for the prevention of disease are dropped. $" 5$

Aldermen had discussed the problem of refuse removal. In 1885 Thomas Amott raised the possibility "of emptying gratuitously the dustboxes of the city" but was not supported: on

3. M. 24 October 1887.

4. Ibid 10 October 1887.

5. T.N. 12 January 1887. 
31 October 1887 Amott asked the Council to reconsider the matter. 6 Amott argued that "disease was germinated" by the large heaps of filth which had accumulated since pigs had been prohibited from the city by the Public Health Act (Hobart) 1884. Citizens should deposit house refuse in boxes and place the boxes in front of their houses for scavengers to empty once a week. George Davies said the Health committee had considered the matter for some time but cost was a barrier. The Health committee favoured the Manchester system whereby pans and dust boxes were carried away in one vehicle. This system cost between $£ 7,000$ and $£ 8,000$ a year and required an extra rate of $2 \mathrm{~d}$. in the pound. Aldermen accepted the principle of refuse removal but were chary of any scheme that would Increase rates.

Am ott persisted and on 19 December proposed that "with a view to stimulating the citizens residing in the thickly-populated portions of the city to preserve strict cleanliness in their back premises, thereby promoting the health and comfort of the citizens in general", the Council should, from I January 1888, remove vegetable garbage and household refuse "in certain areas of the city" free of charge if placed in dustboxes at a convenient place for the scavengers. ${ }^{7}$ The area should include at least the business parts of Macquarie, Collins, Liverpool, Bathurst, Argyle, Elizabeth, Murray and Harrington Streets and the service should be performed not more than once per week. The motion was passed without discussion. This section of the city contained properties owned

\footnotetext{
6. M. 1 November 1887.

7. Ibid 22 December 1887.
} 
by the largest ratepayers, those who could most afford to pay for the service, and was an example of their dominance in Hobart. The Mercury regarded the decision as "a small step" in the right direction. 8 The public would be better served if all household refuse was removed at regular intervals "not at the will of the householder, or in consequence of what he may do, but as part of a municipal sanitary system", which would enhance the city's reputation as a health resort.

On this limited scale the refuse was efficiently removed but all attempts to extend the service were denied on the grounds of expense. Some aldermen suggested that the prohibition of pigs from the city had resulted in "Increasing sickness" amongst the poor and wanted the restriction lifted but this was an isolated cry. ${ }^{9}$ The unclean state of the city by 1891 was one reason for the formation of the Sanitary Associations. Edwin Rogers said the Hobart Sanitary and General Improvement Assoclation was formed "because of the dirt and filth of the City and the streets generally ..."10 In October 1891 the Sanitary Association failed to persuade the Council to extend the service to outlying streets. 11 On 7 December, the eve of the Council elections, aldermen adopted a motion by Amott to order scavengers to collect from houses refuse boxes placed on the street. ${ }^{12}$ By July 1892, according to the Women's Sanitary Association, this had not been implemented. ${ }^{13}$

8. Ibid 22 December 1887.

9. Ibid $15 \mathrm{July} 1890$.

10. T.P.P. $1901 / 5$ p.78.

11. M. 6 October 1891 .

12. Ibid 8 December 1891.

13. Ibid 3 July 1892. 
In November 1892 a special committee of the Council presented a report on retrenchment to reduce expenditure. One proposal was to dispense with the house to house inspector and give the police the duty of sanitary inspection. ${ }^{14}$ This would save £93 12 s. per annum. It meant, said Davies, that "prosecutions could be carried out without the Mayor or aldermen being called upon to lay informations and it would have a very salutary effect on the sanitation of the city". Alderman Crisp opposed the proposal "because he believed that people objected to having policemen coming about their backyards". The use of police in Victorian towns, wrote the Mercury, proved unsatisfactory because sanitary work was "special work" and required "experience and aptitude": the police "rarely perform it otherwise than in a loose and unscientific fashion". 15 The other proposal concerned street sweeping. The committee felt that the cost, being $£ 1,055$, was too large and "the work was not done satisfactorily": the work could be done "cheaper and better" by tender and divıding the city into sections for scavenging. The experiment was tried in 1893 but was shortived: by September the contractor George Flynn asked the Council to cancel the contract and the Council resumed control of the work. ${ }^{16}$ John Bradley offered another solution to cope with the refuse thrown onto the streets. ${ }^{17}$ He suggested that 12 pillar boxes be placed "in the prancipal parts of the city" as receptacles for refuse and that 6 boys be employed to keep thoroughfares clean. As retrenchment and economy dominated civic thought Bradley's proposal received no support.

\footnotetext{
14. Ibid 25 November 1892.

15. Ibid 26 November 1892.

16. Ibid 5 September 1893; M.C.C. $16 / 87 / 3$ for information on the tenders.

17. M. 29 November 1893.
} 
The Mayor's valedictory address in December 1894 praised the clean condition of the city but the defects in sanitary inspection were exposed in April 1895 by an Inspection Committee visiting rivulets in various parts of the city. ${ }^{18}$ The Inspection Committee, of which more will be written in the section on rivulets, found "a huge refuse tip" near Bishopscourt on the Wellington Rivulet, allegedly formed by the Council. In a block running parallel with Elizabeth Street, between Warwick and Patrick Streets, was "a large stagnant pool .... which stunk abominally" and was known as "the Plague Spot" or "the Pool of Aborigines". 19 Above the pool was another Corporation tip where was deposited "all kinds of rubbish and abominations in large irregular heaps, whilst between the heaps stood filthy pools". The area was a playground for children and typhoid germs. Poor people living in shanties surrounding "the Plague Spot" repeatedly complained to the Corporation without success: one resident claimed that the land was owned by an alderman. It was later disclosed that in September 1894 the City Inspector had advised that the block be drained but his advice was disregarded. 20 This was added evidence, wrote the Tasmanian News, that "health and drainage matters are only half-attended to where the poor live". 21

Bradley blamed sanitary officials and past aldermen for neglect of this kind: the Council, he thought, "had to be driven almost at the point of the bayonet to rectify abuses". 22 Thomas Dillon, an alderman with a limited vision of the Council's role in the city, said he owned the ground at Elizabeth Street and

18. Ibid 11 December 1894, 23 April 1895.

19. Ibid 20 April 1895; T.N. 20, 23 April 1895.

20. T.N. 21 May 1895.

21. Ibid 23 April 1895.

22. M. 23 April 1895. 
had given permission for it to be used as a tip. He intended to convert the area "into good building ground by compelling the Corporation to do their duty in constructing the drain which ran there". Here was an example of how an alderman could use his position for personal gain. Dillon wanted to soak up the swamp with refuse and persuade the Council to drain the ground in order to build houses. Such an action caused a nuisance and threatened the health of the poor people living nearby and was illegal. Despite Dillon's admission a report of the Health and Sanitary committee absolved him of guilt: "improper material" was deposited there without the knowledge of the owner Thomas Dillon and blame was laid on the adjoining owners. 23 It recommended that the area be drained.

In his first annual report Sprott advocated the "systematic" removal of refuse but without success. ${ }^{24}$ By 1900 the removal of refuse remained confined to the business section of the city. 25 Sprott warned: "the neglect of back premises is a notorious evil, and one which tends to create festering beds of disease year after year". The bubonic plague scare in the first quarter of 1900 galvanised the Council into actıon. The thought that plague would gain a foothold terrified people. One correspondent to the Mercury, "The Midland Medium", regarded the plague as "a terrible disease - more to be dreaded that smallpox itself": its appearance would be "a national calamity". 26 The Mercury received numerous letters on bubonic plague "all of which we cannot possibly publish and would do no good and only create alarm if they were published .... many suggestions are wild in the extreme". 27

23. Ibid 21 May 1895.
24. Ibid 8 December 1896.
25. Ibid 14 February 1900.
26. Ibid 19 March 1900
27. Ibid 27 March 1900.


Newspapers continually drew a direct connection between filth and bubonic plague and there was a conviction that the Corporation was not adequately cleaning the city to lessen the chance of the plague appearing. On 25 March, at a public meeting on bubonic plague, the chairman, Dr. Harry Benjafield, pre-eminent controversialist, said that the plague was "never found except amongst filth and other insanitary conditions", but throughout Hobart in areas like Wapping "there were dwellings which should long since have ceased to exist and near the wharves shanties swarming with rats" would make "happy hunting grounds for bubonic fever if it landed here". 28 A deputation of most of the parliamentary representatives of Hobart, doctors, clergymen, lawyers, tradesmen and representatives from suburban local boards assured "the Corporation of the support of the citizens in spending money in putting the city in as good sanitary state as possible". 29 The Mayor, George Davies, told the deputation that for the past month the Council, with the help of the police, had been inspecting every house in the city and ordering people to remove rubbish: a man was employed to burn rubbish at the tIps, under the supervision of Sprott. To remove rubbish from all premises each week would add another $1 \frac{1}{2} \mathrm{~d}$. to the rates and he doubted whether it would be acceptable to ratepayers. Thus some work was underway but to many citizens it was inadequate. On the 9 April the Hobart Sanitary and General Improvement Association was re-established to exert further pressure on the Council. 30

On 2 May the Government held a conference with the City Council and the Marine Board and it was decided to share the ex-

28. $\quad$ Ibid 26 March 1900.
29. Ibid 29 March 1900.
30. $\quad$ Ibid 10 April 1900.


pense of ridding the city of rats, the major carriers of the plague to humans. ${ }^{31}$ The Rat Extermination Committee comprised Dr. Bright and Thomas Bennison of the Central Board of Health, Aldermen Henry and Snowden, and Warden Evans and W.J. Watchorn from the Marine Board: Alfred Mault was Secretary and William Brain was Supervisor. Brain was instructed to employ 10 men to lay poison and set traps: sewers, all rivulets, public buildings, the slaughteryard near the wharf and the tips were fumigated with sulphur. 2d. was offered to private citizens for each dead rat brought to the Corporation yard in Lower Collins Street. Houses and businesses were sent circulars with precautions to take when handling rats and to remind people to exercise "scrupulous cleanliness of person, and of dwellings and surroundings ..." The suburbs surrounding Hobart declined to join the Rat Extermination Committee, claiming their districts were not disturbed by rats. The Hobart Corporation continued to kill rats, either on its own or with other bodies, until 1914. In 1897 a bacteriological laboratory was set up at the General Hospital and Sprott, as we know, was appointed honorary bacteriologist, but it appears that no analyses of suspected bubonic plague cases were made. ${ }^{32}$ No case of bubonic plague was recorded in Hobart.

The bubonic plague scare had the beneficial effect of cleaning the city on an unprecedented scale but the work was not sustained and by February 1901 the accumulation of refuse was still "a common cause of complaint". 33 Brain told the Royal Commission into the Municipal Government of Hobart and Suburbs that he had

31. T.P.P. 1901/6.

32. W.G. Rimmer, Portrait of a Hospital : The Royal Hobart, (Hobart 1981), p.160.

33. T.P.P. $1901 / 5$. 
advised the Council to remove rubbish from all houses in the city. A weekly removal would cost the Council $f 850$ annually, requiring a rate of $1 \frac{1}{2} \mathrm{~d}$. in the pound, but this would save ratepayers money. Brain estimated that the average assessment of houses in the city was $£ 30$. A rate of $1 \frac{1}{2} \mathrm{~d}$. would total 3s. $9 \mathrm{~d}$. per year. It cost from 1s. to $1 \mathrm{~s}$. 6d. to have a single load removed and if a load was removed every four months it would cost approximately $3 \mathrm{~s}$. $9 \mathrm{~d}$. and houses would be filthy for long periods. A weekly removal would be more economical and houses much cleaner and healthier. Put in this way, the argument was very attractive and the sympathetic Council that emerged in 1902 gave it serious consideration. In December 1902 Mayor George Kerr wrote that aldermen were increasingly coming to the conclusion that "a more systematic method of collection" was required. 34 The Public Works committee, which included Bennison and Gould, often discussed the initiation of garbage collection. 35 On 29 December, when Bennison was Mayor, he, with the Town Clerk and City Surveyor, drew up regulations dealing with garbage collection and these were adopted by the Council. ${ }^{36}$ The new system would come into force in February 1903. The city was divided into three sections. 37 In the central section refuse was removed daily; in the intermediate section twice a week; and in the outer section once a week. Citizens were encouraged to purchase "a uniform pattern" refuse bin. Garbage removal was not made compulsory. That the cost of the system was subsidised from existing rates and no new rate was

34. M. 9 December 1902 .

35. M.C.C. $16 / 61 / 4-5$ for minutes of the Public Works committee

36. Ibid 29 December 1902; M.C.C. $16 / 67$ p,89.

37. M. 8 December 1903. 
levied, explained the lack of opposition to the measure. Garbage collection was the earliest achievement of sanitary reformers and was the starting point of Hobart's era of municipal progress.

Residents did not rush to have their garbage removed. In his valedictory address of 1904 Bennison expressed disappointment that, although done for free, "citizens have not availed themselves to so great an extent as might reasonably be expected ... of getting rid of their house refuse". 38 By 1909 only 1300 bins were collected by the garbage carts from the city's 6,500 tenements. $^{39}$ Collection was not carried out unless householders used standard bins, which many could not afford. Sprott recommended that "the rubbish be taken from any receptacle approved by the department and that bins be supplied free of charge to all houses rated under $£ 20$ per annum", but this was not taken up. By 1913 less than 40 percent of houses had "proper garbage bins" and Sprott thought it was time to compel citizens to purchase "a metal receptacle, cylindrical in shape, watertight, and with a lid". 40 Despite the increased use of garbage bins, there was some dispute about how clean Hobart had become. In June 1913 Alderman James Dunn alleged that he had discovered a number of dirty and insanitary backyards during his work as a builder. ${ }^{41}$ A report by Sprott did not deny that some insanitary yards existed but they were "the exception and not the rule": Sprott thought that "Hobart took the leading place amongst the cities of Australia for health and cleanliness". ${ }^{42}$ This was a large claim but it is certainly true that Hobart was much cleaner in 1914 than in 1886.

38. $\quad$ Ibid 6 December 1904.
39. $\quad$ Ibid 9 March 1909.
40. $\quad$ Ibid 22 July 1913.
41. $\quad$ Ibid 24 June 1913.
42. $\quad$ Ibid 24 June 1913.


Collection was one aspect of the garbage problem: disposal was as important. The use of a destructor had been advocated by Mault and most sanitary reformers preferred destructors to tips. One of the first papers of the Sanitary Association, prepared by Dr. J.A. Hardy in 1893, considered the operation of destructors. 43 Hardy wrote: "the principle of destruction of rubbish by fire had been recognised by sanitary engineers and others as being the only solution to the refuse problem". In 1894 the City Surveyor Milles recommended purchase of a destructor and in 1896 Sprott lent his support. ${ }^{44}$ In February 1897 the Council sought a quote on the price of various types of destructors and eight months later a special committee was appointed "to obtain all necessary information as to the probable cost, design and working of destructors". 45 The Tasmanian News urged the purchase of a destructor to rid the city of "the most objectionable eyesores and plague traps, the tıps". 46 However the cost of destructors was considered to be prohibitive and the matter was not pursued.

Annual clean-ups triggered by the bubonic plague drew closer attention to the state of the tip near the slaughteryards. In December 1902 Edward Mulcahy complained that it was "a depositing place for all sorts of garbage, household refuse, dead animals of all kinds and other even worse things likely to create and disperse disease germs". 47 Milles reported that the tip was filling up and required "constant supervision" to ensure refuse

43. T.N. 6December 1893; see M.V. Melosi, Garbage in the Cities; Refuse, Reform and the Environment 1880-1980, (Texas, 1981), p.47-9, 170-6 for American views on incineration.

44. MCC $16 / 56 / 6$ p.720-5 for Milles' views; M. 8 December 1896.

45. M. 2 February, 19 October 1897.

46. T.N. 19 October 1897.

47. M. 9 December 1902 . 
was properly dealt with; he thought the need for a destructor was "very urgent". ${ }^{48}$ A destructor was not purchased but objectionable refuse, such as fish and offal, was taken down river with the city nightsoil and the city tips received the rest. 49

No sanitary reform was more universally favoured after 1903 than the purchase of a destructor. In its early issues the Daily Post, which vehemently attacked the use of the tips, summed up the opposition: "Any continuance of the tip system, no matter where and under what conditions, may be at once set aside, as prohibited by the growing size of the city, and the absolute necessity of conserving its health in every way". 50 In October 1908 the Daily Post interviewed Mayor Daniel Freeman, who said the existing tip was "rapidly becoming inadequate for our needs, and something will have to be done, if another dumping site cannot be found". 51 The purchase of a destructor was under consideration, continued Freeman, and was "purely a matter of finance": the Council had "a great many things to do, and I am of the opinion that these must be completed before we install a destructor". The cost argument was criticised by the Tasmanian News: "The chief consideration .... is the best means of disposing of the garbage of the city, so that the reputation of Hobart as a tourist resort, may be enhanced, and the health of the people conserved. The question should not centre on cost ..." 52 In April 1912

48. Ibid 16 December 1902.

49. Ibid 8 December 1903.

50. D.P. 20 August 1908.

51. Ibid 29 October 1908.

52. T.N. 20 October 1911; Critic 29 April 1911 for a similar 
the Chief Health Officer J.S. Purdy prevailed on the Chief Secretary to "strongly recommend that the Council purchase a destructor, possibly in combination with surrounding municipalities. 53 However as later in 1912 the Marine Board made more land available at the tip site, the Council had no incentıve to buy a destructor. 54 In his annual report of 1914 Sprott considered a destructor to be "a sanitary necessity" but it was not decided to instal one until 1918. 55

Nightsoil

a) The Pan System of Nightsoil Removal

In his 1886 report on Hobart's sanitary condition, Mault described the way in which residents coped with the perennial problem of ridding their houses of nightsoil. 56 Hobart embraced an area of 1,270 acres and contained about 4,500 houses: less than 400 houses had water closets, 600 used the pan system and 3,500 used cesspits. By the Public Health Act (Hobart) 1884 the use of cesspits had to end in January 1887 and the cheapest alternative was the pan system. Most of the pans were periodically emptied by men employed by the Council at a cost of $6 s$. $6 \mathrm{~d}$. a quarter for a pan emptied weekly and 3s. 6d. for a pan emptied fortnightly. The owners or occupiers of a house provided the pans, which were not in duplicate. Thus the pans were emptied into the nightsoil cart, scraped out and returned: there was little opportunity to clean the pan. Mault recommended that

53. M. 2 April 1912.

54. Ibid 10 December 1912.

55. D.P. 9 June 1915; Hobart Corporatıon Loan Act 1918.

56. T.P.P. 1886/47, p.9; For a light-hearted look at rightsoil in Brıtish history see T. McLaughlın, Coprophilia or a Peck of Dirt, (London, 1971). B. Barrett, The Inner Suburbs: The Evolution of an Industrial Area (Melbourne, 1971), chapters 4 and 5 has shown how the suburbs of Collingwood and Fitzroy coped with cesspans; see also C.T. Stannage, The People of Perth: A Soclal History of Western Australia's Capital City, (Perth, 1979), p.152ff. 
the duplicate pan system, with airtight lids, be used and that the Council purchase pans.

The contents of the pans were carted to farms at New Town and Sandy Bay, where it was used as manure without being disinfected. Mault warned that this did not "rid nor destroy the specific poison .... of any disease that may be prevalent". The deposit of nightsoil at Sandy Bay led to numerous letters to the Mercury complaining of a "horrible and awful" stench from the farm overlooking the bay where nightsoil was left and of "a dangerous and repulsive fluid" flowing down onto the beach where children played. 57 The miasmatic theory of disease, as we know, associated smells with disease and Giblin and Mason visited the farm. They found that the smell arose from decomposing seaweed left on the beach by low tides. 58 Nightsoil created a slight smell but this was alleviated by not leaving it in heaps and covering it with dirt in trenches. Then some residents in Sandy Bay compiained of being kept awake by "the incessant rumbling" of the night carts. 59

The inadequacies of the pan system were exacerbated as more people used it. This was acknowledged in February 1887 by George Davies, who moved that, for "the protection of the public health and the prevention of nuisances", the Council should undertake the emptying and inspection of all earth and other closets. 60 The content of pans, he said, was thrown into side gutters, back drains and "other equally objectionable places", leading to an increase in diseases like diphtheria, typhoid and scarlet fever. Reduction in the incidence of these diseases would only occur if

57. M. 17 December 1886.

58. Ibid 29 December 1886.

59. I.P.P. $1887 / 78$ C.B.H. annual report.

60. M. 22 February, 1 March 1887. 
the Council took over "the control and management" of earth and water closets. It would be cheaper for all ratepayers to pay a sanitary rate of $3 \mathrm{~d}$. in the pound to have pans emptied than to pay private contractors a fixed amount as was done by many. Aldermen agreed with Davies that the pan system needed reform. ${ }^{61}$ Alderman Rait claimed that it had as many defects as cesspits. Alderman Dillon had no doubt that it was responsible for the recent outbreak of typhoid. Davies's motion was passed. The Health committee was instructed to report on the best way to improve the pan system.

Members of the public wrote to the press about the rise of typhoid and equated it with the defective pan system. The Tasmanian News agreed and thought that "matters have reached a crısis" because Hobart "one of the most beautiful resorts, [was] becoming a plague-stricken city": the pan system was an "unmitigated failure". 62 As we have seen, the Ratepayers' Associations were formed to seek improvements to the pan system. The Mercury disagreed with those who attributed the typhoid epidemic to the pan system, quoting figures to prove that typhoid was always more prevalent in the first three months of the year in Hobart, Launceston and Melbourne than any other time. ${ }^{63}$

Amidst this controversy, the report on the pan system was presented to the Corporation on 4 April 1887.64 The report recommended that the Council bear the cost of the pan system;

61. Ibid 15 March 1887.

62. T.N. 22, 23, 24 March 1887; see also L. Norman, Haunts of the Blue Whale, (Hobart 1978), p.66-7.

63. M. 1 April 1887 .

64. Ibid 5 April 1887. 
that tenders be advertised for one, two or three years for emptying pans weekly, with or without deodorants; that all leaky pans be replaced at the cost of the contractor; that the nightsoil be the property of the contractor "under certain restrictions" as to locality and method of disposal; that the cost be defrayed by a sanitary rate; and that the city be divided into six sections to carry out the work. The Health committee considered systems used in Victoria and judged that a compulsory system, financed by a sanitary rate, was the best. The rate to be charged was deferred but the rest of the report was adopted. On 18 April Alderman Amott moved that a charge for the removal of each pan be substituted for a sanitary rate. ${ }^{65}$ He argued that a fixed sanitary rate would be an unjust burden on small ratepayers: the motion was passed six votes to two.

In June Davies moved that the duplicate pan system be instituted. 66 He convincingly argued that the present system was not working. Emptying pans at night filled the air with "poisonous gases", the night carts woke people up and backdoors had to be left unlocked at night for nightsoil men to take the pans but in a number of houses there were no back doors and "the pans and the contents had to be taken through the house". Davies favoured the St. Kilda system whereby duplicate pans, with air-tight lids, were removed during the day. Aldermen unanimously voted for the motion. By November four tenders had been received for the pan contract. 67 The lowest tender, put in by Cox and Hore, was accepted, subject to the approval of the Central Board of Health,

65. Ibid 19 April 1887.

66. Ibid 28 June 1887.

6́7. Ibid 18 November 1887. 
but the Council was criticised for the tardy way it approached the nightsoil dilemma. The Tasmanian News grumbled that it had taken "months of wearying discussion, of unaccountable, and under all the circumstances, criminal delay". 68 The Council, wrote the Mercury, had done, and would continue to do, a great deal of talking about sanitation, but it was "not doing or attempting to do one-half of what is required to be done". ${ }^{69}$ The Central Board of Health concluded in its annual report of 1887 that the typhoid epidemic "taught no profitable lesson to the sanitary authorities" of Hobart. 70

Modifications to the contract were made, on the advice of Mault, by the Central Board of Health. ${ }^{71}$ These included the use of airtight pans, that nightsoil be covered with earth, shortly after deposit, to a minimum depth of six inches and that the pans be disinfected, all of which were accepted by the contractors. Despite the protest of nearby residents, a deposit site on a farm at South Glenorchy, owned by Dr. Harry Benjafield, was approved, by the Central Board of Health, for three months, provided pans were deodorised. The contract was signed and confirmed on 18 January. ${ }^{72}$ Cox and Hore were to be paid $2 \mathrm{~s}$ per pan for every pan removed and by 20 February 3000 pans were distributed. 73

Problems arose in carrying out the contract. It was alleged that pans were not emptıed if fees were not paid. ${ }^{74}$ In one case

68. T.N. 26 November 1887.

69. M. 20 December 1887.

70. T.P.P. 1888-9/102.

71. M. 18 January 1888.

72. Ibid 19 January 1888.

73. Ibid '2l February 1888.

74. Ibid 3 February 1888. 
a pan of a widow was not removed for several weeks and typhoid was caught. The Mercury regarded it as "monstrous" and "criminal" to threaten the health of the city for "a few shillings". According to the contractors, the pans supplied by the Council broke easily and the lids did not fit securely. The City Inspector claimed that the contractors had insufflcient men and carts to remove all the pans from each section of the city in one day and his staff emptied pans that were missed or left unemptied: also pans were not washed with steam jets as specified in the contract. 75 This was confirmed by Giblin. Alderman Rait accused the contractors of loading too many pans on the cart: the carts held 40 pans comfortably but the contractors tried to load over 100 pans and the carts were not covered. The pans were also reported to have been distributed without being tarred or painted and had started to leak. ${ }^{76}$ The Mercury criticised the "want of care and want of organization" of all involved with the pan system: crtizens were careless with the pans, the Council bought pans with lids that did not fit and the contractors did not clean the pans. $77^{\text {. }}$ Negligence was clearly shown in that clause of the contract framed by the Corporation requiring the contractors to remove nightsoil by day. This was a contravention of section 226 of the Police Act 1865, whereby nightsoil could only be removed between midnight and 5 a.m. ${ }^{78}$ Residents of South Glenorchy had Cox and Hore prosecuted and fined by the Glenorchy Police Court: the contractors refused to pay and were imprisoned but released on

75. Ibıd 21, 28 February 1888.

76. Ibid 22 February 1888.

77. Ibid.

78. T.P.P. 1888-9/118 C.B.H. annual report. 
the instruction of the Attorney-General, pending an appeal to the Supreme Court. ${ }^{79}$ The Supreme Court ruled that no regulation made by the Central Board of Health or Local Boards of Health under the Public Health Act 1885 could overrule provisions of the Police Act 1865. 80 The Tasmanian News lamented that no contract was "more rashly entered into and more absurdly carried out than the immortal nightsoil contract". 81 No single issue more undermined confidence in the Corporation.

After the three month trial period ended a deputation from South Glenorchy persuaded the Central Board of Health to direct the Council to find a new deposit site. ${ }^{82}$ Land on the wharf, near the Gasworks and the slaughteryard, owned by the Government, was chosen by the Council. The Government allowed the Council to use the land but after pressure from the Gas Company, butchers and nearby residents, withdrew permission. 83 Aldermen made no attempt to find a new site and on 22 January 1889 an incensed deputation told the Minister of Lands Alfred Pillinger that, under the Public Health Act; they could appeal to the Supreme Court. 84 Pillinger succumbed and gave the Council seven days to move from the site. The Council remained obdurate. On 6 February Cox and Hore were locked out of the Gaswork's depot: the pans could not be collected because they had nowhere to empty them. 85 This left Hobart, wrote the Mercury, "in a state which is repugnant

79. M. 1 May 1888 .

80. Ibid 5, 9 May 1888 .

81. T.N. 9 May 1888 .

82. M. 28 April, 10 May 1888.

83. Ibid 31 May, 2 June, 26 June, 27 November 1888.

84. Ibid 22 January 1889.

85. Ibid 7 February 1889. 
to decency and dangerous to health". It also had legal implications: section 143 of the Public Health Act held that any Local Board failing to remove nightsoil from a house within seven days was liable to pay the occupier a penalty not exceeding $5 \mathrm{~s}$. for every day this duty was not discharged. The possibility of a large pecuniary loss was a potent spur to the economy minded Council. The Corporation lumber yard in Lower Collins Street was used as a temporary depot. 86 The choice of site was critical but, wrote the Tasmanian News, "the onus of selection was shirked by those who are supposed to be the guardians of health and morals [the City Council] and put upon a couple of men whose power was small and whose experience was limited". 87 To allow "the ordure chariots" to traverse the city streets "would be an eternal disgrace to any other community" and showed that the Corporation, as the Local Board of Health, was "a gross imposture", fitted by "neither education nor experience" for the job. 88

It was obvious that the sanitary contract was unworkable. However the contract had two more years to run and advice from A.I. Clark, the Attorney-General and Corporation's counsel, indicated that the Corporation would have difficulty in dissolving the contract: fortunately on 20 March Cox and Hore consented to relinquish their contract if the Council "release our bondsmen, return our security and pay us our account in full" and "take over our plant at a fair and reasonable valuation". 89 The Corporation decided to cut its losses. On 30 March the contract ended. 90 The Council removed the nightsoil until December and in that period

86. Ibid 8, 9 February 1889.

87. T.N. 19 February 1889.

88. Ibid 25 February, 14 March 1889.

89. see MCC 16/9 25 February 1889 for Clark's opinion, which implicated the Council in the contractors' "various laches"; M. 21 March 1889.

90. M. 6 April 1889. 
"a great improvement" was visible. 91 Tenders were called and that of J. and J. Stephens was accepted. The senior partner of the company was Alexander Riddoch, an ex-alderman, whose business acumen and integrity inspired confidence that the dangerous travails of the past would not recur. ${ }^{92}$ The new scheme was similar to the old one. 93 Pans were collected during the day. Lids were placed on new pans and taken to the Gasworks' depot. The pans were removed once a week, but more frequently if necessary, cleansed and replaced at 4d. per pan for each removal. An important difference was that the pans were conveyed by steamer to a farm at Ashburton Peninsula, about nine miles upstream. Most complaints were associated with the conveyance of nightsoil "along the public thoroughfares" but this was now avoided. 94 After one year the City Inspector concluded with relief that the pan system was carried out "in a much more satisfactory manner than at any previous time since the system has been adopted". 95 The protracted struggle to find a solution to the removal of nightsoil shows that the pan system, ostensibly an improvement, created more difficulties than it overcame. The fear engendered by the typhoid epidemics of 1887 to 1889 and the apparent link with the pan system was a catalyst for change. It is easy to be critical with the benefit of hindsight but the legal tangle caused by the contract and the failure to find a suitable sanitary depot would not have been difficult to resolve with careful planning. Also, as the Central Board of Health pointed out, the contractors

91. T.N. 6 June 1889.

92. Ibid 22 January 1889 .

93. MCC 16/7/13/p.398; M. 22 January 1890 .

94. T.P.P. 1890/25 C.B.H. annual report.

95, M. 7 January 1891. 
"only interest in the matter" was "monetary and not sanitary" and they did what they could to limit costs to the detriment of health. 96 Once the sensitivity of citizens to the removal of nightsoil showed itself publicly the parties involved tried to escape responsiblity for the anomalies. Public pressure, induced by fear of typhoid, was essentially negative: deputations told the Council what it could not do but offered no solution or measures to improve the removal of pans. The Sanitary Associations were more helpful, recommending sensible improvements and some were implemented. The pan system depended upon individuals taking care not to damage pans and to use ashes and deodorisers to minimise the baneful effects inherent in it. This was not generally done: by December 1896 they were rarely used. ${ }^{97}$

By 1901 there were over 800 water closets in the city, "some cesspits" and the pan system was "generally in use". 98 The sanitary rate had been adjusted a number of times to achieve a more equitable balance between rich and poor: by 1900 householders assessed at $£ 24$ and under paid $12 \mathrm{~s}$. and those over $£ 24$ and over $6 \mathrm{~d}$. in the pound. In the suburbs surrounding Hobart various methods were used to cope with nightsoil. A private contractor removed pans in Queenborough but the system was "very insufficient and not by any means general". In the other suburbs nightsoil was mainly buried in gardens, which were more spacious than in the city; a small number of houses paid for it to be removed. The Royal Commission of 1901 found that "a large section of the public .... do not take much interest in keeping the pans

96. T.P.P. 1889/96.

97. M. 8 December 1896.

98. T.P.P. $1901 / 5$. 
clean".99 The pan system, it considered, was an advance on cesspits but could never be made completely safe and should be discontinued when the metropolitan drainage scheme was completed.

By 1904 the Hobart Corporation had made such strides in managing the pan system that, at their request, it was carried out for the Glebe Town, Queenborough, Mt. Stuart and Wellington Town Boards. ${ }^{100}$ The faults accompanying the pan system were minimised as contractors and citizens became more familiar with it and very few complaints were heard. The pan system was not the best and healthiest way to deal with nightsoil but it was the cheapest and, in the absence of facilities for general use of water closets, the least hazardous.

b) Water closets and Rivulets

Environmental pollution of some kind blighted the lives of urban residents in the nineteenth century. 101 Whether pollution was industrial or human, civic officials were forced to confront and overcome the source of pollution. In Hobart the pollution of rivulets by human Ignorance and laxity was a major problem. The largest rivulet was the Hobart Rivulet, which, in 1843, was sanctioned by legislation to be used as a public sewer. ${ }^{102}$ By the 1880 s water closets drained into the Hobart Rivulet and refuse was thrown into it, remaining there to stagnate, trapped by large

99. Ibid.

100. Hobart Gazette 27 June 1905, p.646, which gives figures on the cost to these boards.

101. For a useful historical account of the scope of urban pollution see M.V. Melosi, (ed.) Pollution and Reform in American Cities, 1870-1930, (Austin, 1980); G. Bolton, Spoils and Spoilers: Australians make their Environment 1788-1980, (Sydney, 1981) briefly looks at pollution in Australian. cities.

102. For an extended treatment of the Hobart Rivulet see J. Button, "The Rise and Fall of the Hobart Town Rivulet: An Historic Preservation Study", unpublished Graduate Diploma of Architecture Thesis, Tasmanian College of Advanced Education, 1978; T.P.P. 1881/121; N.J. Barton, The Lost Rivers of London, (London, 1962), chapter 10 for rivulets and disease in Londor. 


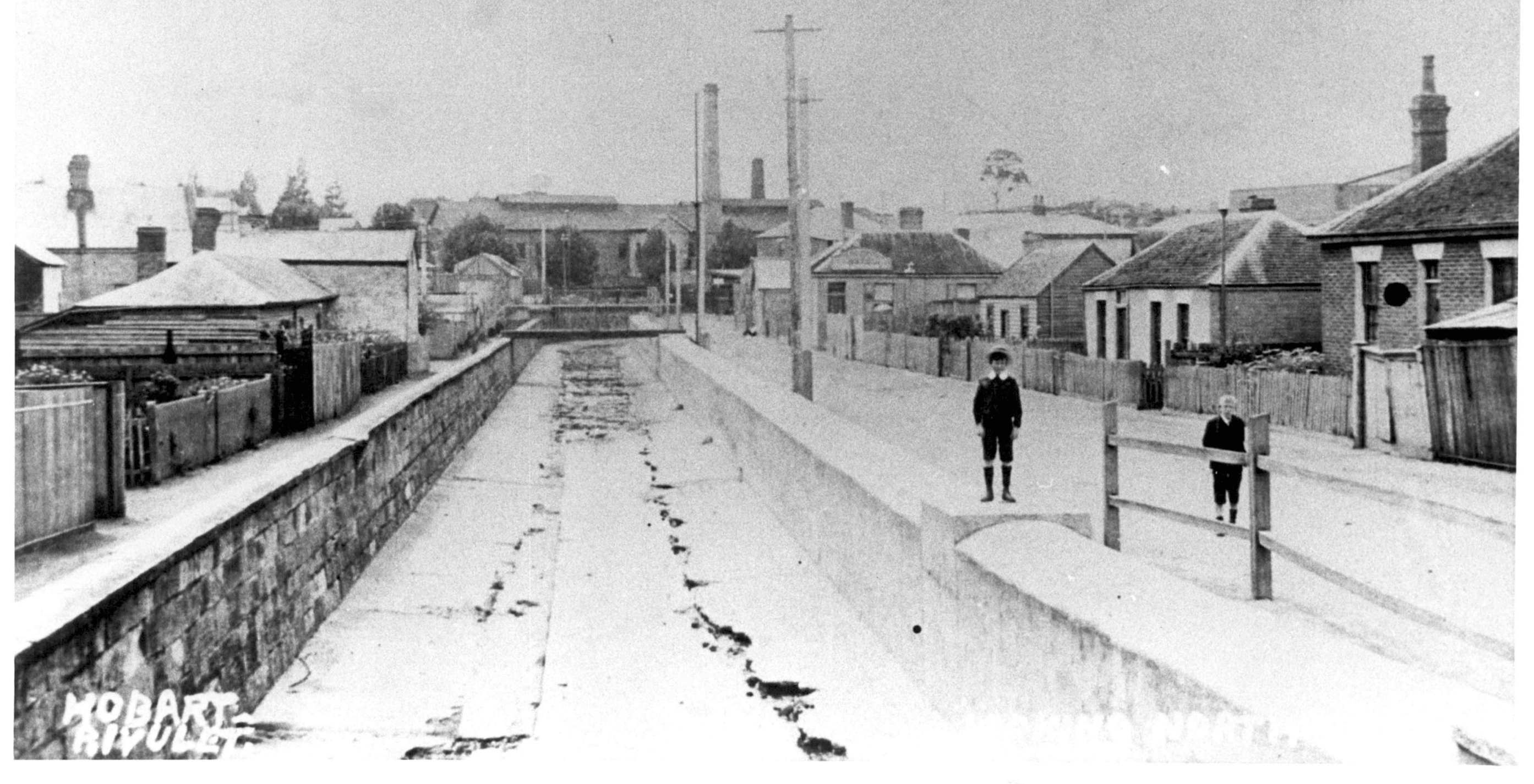


boulders. Cleansing was a temporary expedient and filth soon built up. The Hobart Corporation erected retaining walls to stop boulders from falling in and obstructing the flow of water that carried the refuse out to sea. In the 1880 s paving the bed of the Rivulet was begun but progress was slow due to a lack of funds. Such measures were only partially successful because they attacked the symptoms and not the causes of pollution. A change in the law to stop the dumping of refuse into rivulets and to cut off water closets was needed more than public works.

The Hobart Rivulet was the most glaring example of a polluted watercourse running, as it did, through the centre of the city: other water courses or rivulets, scattered throughout the city and on its boundaries, were even more neglected and disease was often found amongst those living along their courses. In his 1886 report Mault recommended that rivulets should be cleansed and used for natural stormwater drainage: sewerage from water closets and house-slops should run into properly built sewers. ${ }^{103}$ In October 1891 one of the first reports of the Sanitary Association concerned improvements to the Hobart Rivulet. ${ }^{104}$ On 18 October 1892 the Sanitary Associations persuaded the Central Board of Health and the Corporation to attend a conference on rivulets. 105 George Seabrook argued for the construction of flood-gates for the Hobart Rivulet at a cost of $£ 400$ to $£ 500$. Alderman John Baily said suitable flood-gates would cost $£ 12,000$ to $£ 15,000$ and were beyond the Council's finances. Mault agreed with Baily's estimate and was uncertain if the volume of water was adequate to flush the rivulet. He preferred paving the bed from beginning

103. T.P.P. $1886 / 47$.

104. M. 12 October 1891.

105. Ibid 18 October 1892. 
to end and appointing a special inspector to remove obstructions. Most speakers were persuaded by Mault and a resolution that the Corporation immediately clean all the rivulets was passed.

When John Bradley became an alderman, he attacked the source of the problem. On 3 January 1893 he moved that the Corporation give a month's notice to "all owners or agents of houses where water closets exist, and the nightsoil runs into any of the creeks, or tributaries of creeks, within the city boundary (other than those which flow into the Hobart Rivulet within the prescribed area allowed by the Act)" to cut off the water closets and use the pan system. 106 Discussion was adjourned for two weeks in order to establish the Council's legal right to cut off water closets. On 16 January, speaking to his motion, Bradley argued that the rivulets were poorly constructed and never cleaned: nightsoil from water closets was left to stagnate. ${ }^{107}$ In summer the nuisance was critical because water was insufficient to flush the creeks, causing "much of the sickness and many of the deaths by fevers". A.I. Clark, in a written opinion, held that by-law six under the Public Health Act had to be rescinded before the Council could order the water closets to be cut off. ${ }^{108}$ Alderman Crisp used this opinion to oppose Bradley's motion and added that, as water closets cost about $£ 20$ to instal, it would be an unfair burden to ask owners not to use them. Also it would not be "wise" to cut off water closets with the approach of the metropolitan drainage scheme. Bradley's motion was lost on the voices. On 13 February Bradley moved as an amendment to by-law six to

106. Ibid 4 January 1893.

107. Ibid 17 January 1893.

108. see T.P.P. 1901/5 Appendix J for a copy of the opinion. 
ensure water closets had sufficient water supply and drainage communicating not "with a public sewer or other outlet approved by the Local Board" but "direct with the Hobart Rivulet, by enclosed sewers approved by the Local Board of Health". 109 This reasonable motion was defeated by four votes to three.

The water closet debate created the same division between public health reformers as did the metropolitan drainage scheme, which will be discussed in the next section. Bradley represented those sanitary reformers who thought water closets runring into rivulets were dangerous to health and who were also reluctant to support the metropolitan drainage scheme because they were concerned that the Derwent would be polluted. Edward Giblin, who owned a water closet, was representative of an alternative view. He did not think that cutting off water closets would lessen the nuisance "to an appreciable extent" because house-slops and liquid sewage would still be carried away by rivulets and gutters. 110 The metropolitan drainage scheme would solve the problem by intercepting solid and liquid sewage and restore rivulets to their original purpose. Water closets were an integral part of the metropolitan drainage scheme, which would run nightsoil into the Derwent. By minimisıng the threat to health posed by water closets, Giblin was by implication defending metropolitan drainage from allegations that it would pollute the Derwent. Despite Bradley's view, some members of the Sanitary Associations, for instance Emily Dobson, owned a water closet. ${ }^{111}$ Wealthy people like Giblin and Dobson, who could afford to own a water

109. M. 14 February 1893.

110. Ibid 24 April 1894.

111. CI. 14 December 1895. 
closet, preferred it to the pan system, which, as we have seen, had many dangers even when properly used.

The summer of $1894-5$ was particularly severe and the hot, dry conditions reduced water running in rivulets to a trickle and accentuated the foul smells emanating from the Park Street and Wellington Rivulets. Aldermen were concerned enough to pass a motion by Bradley that all water closets not properly connected with the Derwent or Hobart Rivulet be closed: the Park Street Rivulet was cleaned "in the usual half-and-half manner" but the Wellington Rivulet, on the boundary of the Town Board of Queenborough, constituted a more serious threat. ${ }^{112}$ People living along the banks of the Wellington Rivulet began to contract typhoid. The Queenborough Board did all it could to remedy the nuisance but discovered that, notwithstanding Bradley's motion, water closets from the city side were running into the rivulet: it threatened the Corporation with legal proceedings if the water closets were not closed. 113 A member of the Central Board of Health and Sanitary Association, Henry Tottenham, was angered by the Corporation's inaction and demanded that the Central Board arrange for a joint inspection of all creeks in the city with aldermen. 114 If they refused he would "bring all the powers we possess to bear on them".

The Corporation assented to the conference. The Mercury thought that the conference should have been held "long ago, for the filthy, disgusting and dangerous system of running the contents

112. M. 30 January, 26 March 1895.

113. Ibid 6, 19 March 1895.

114. Ibid 13 March 1895. 
of water closets into the rivulets has prevailed for many years, has been loudly complained of, has been shown to be a source of grave danger and is being carried on to a greater degree than ever ..." 115 It hoped the conference would result in the closure of water closets for "the preservation of life and the prevention of sickness". On 26 March the conference was held: the Central Board of Health, the Local Boards of Health of Hobart and Queenborough, and the Sanitary Associations were represented. 116 The state of the rivulets was strongly condemned and a committee was appointed to check the claims. Members of the committee were Seabrook, Duff and Bradley of the Hobart Board; Mault, Tottenham and Bennison of the Central Board of Health; and Gregory, Eckford and Salier of the Queenborough Board, all of whom, except Mault, opposed the use of water closets.

The inspections confirmed the worst fears of sanitary reformers. The discovery of refuse tips near some rivulets has already been cited. Most of the Wellington Rivulet was "in a . terribly polluted state". 117 at one point was "a wide, shallow pool of black, slimy stuff simmering in the sun, and which in such warm weather as we have recently experienced must have been a veritable hotbed for fever diseases". The Park Street Rivulet was in an equally disgraceful state and was generally known by residents as "the Valley of the Shadow of Death". 118 The upshot of the exposures was disappointing. Another conference voted for the closure of water closets running into the Wellington and

115. Ib1d 26 March 1895.

116. Ibid 27 March 1895.

117. Ibid 28 March 1895.

118. T.N. 10 April 1895. 
Park Street Rivulets and the Corporation passed a motion to this effect. 119 However this decision had not been enforced by June 1895.

Henry Tottenham was enraged at the delay. It was "a crying shame", he said, that "young people ...., between 15 and 35 years of age, should be murdered .... by the filth of the city". 120 He persuaded other members of the Central Board of Health to act. On 15 July the Central Board, in a letter to the Corporation, named 17 people, including Edwin J. Rogers of the Sanitary Association, who were polluting the Park Street Rivulet and gave the Corporation one month to stop the pollution, as laid down by the Public Health Act. ${ }^{121}$ As a result the Park Street Rivulet was cleaned and a man was employed to ensure it was kept free of pollutıon: the Corporation also passed a new by-law giving it discretionary power to cut off water closets. ${ }^{122}$ The Central Board wanted the power to be compulsory but the Council did not yield. According to the Crown Law Department the Central Board had two options: to seek a writ of mandamus to enforce its order, or to seek an amendment to the Public Health Act, which it preferred. ${ }^{123}$ In 1896, when the Central Board applied for a mandamus, the application was refused. ${ }^{124}$ Amendment to the Public Health Act was the last resort.

A clause preventing the pollution of rivulets was embodied in the Public Health Amendment Bill 1896. On 6 October Philip

119. M. 3 April, 23 April 1895.

120. Ibid 6, 20 June 1895.

121. Ibid 2, 16 July 1895.

122. Ibid 3 September, 8 November 1895.

123. T.P.P. $1896 / 42$ C.B.H. annual report.

124. M. 3 June 1896. 
Fysh introduced the bill but, as an owner of a water closet, did not speak very convincingly for the clause. ${ }^{125}$ George Davies told the House of Assembly that Sprott was preparing a report on rivulets for the Hobart Corporation and his report should be examined before legislation was passed. This was accepted and the clause was struck out on the voices. By 12 October Sprott's report was completed. 126 It was forthright and sensible. He found 858 water closets running into the various creeks and rivulets. (see Table 19) Those running into the Hobart Rivulet "cannot be interfered with" by law and it would not be "advisable to interfere with those that empty into properly constructed sewers". This left 112 water closets "universally agreed" by sanitary authorities to be dangerous to health and a breeding ground for typhoid germs when allowed to run into "unformed creeks or water courses". He noted that "It may be difficult to prove injury to health, nevertheless we must regard polluted streams as a nuisance and menace to the health of the people". Sprott recommended that the 112 water closets be cut off and that the rights of ownership to the creeks be defined to give "full control" to the City Council. Sprott's report stated in clear and unmistakeable terms what action the Corporation should take. His public health training gave his arguments considerable force. While his precursor Giblin was an advocate for a cause, metropolitan drainage, Sprott was impartial: Sprott favoured metropolitan drainage and, as we shall see, was mainly responsible for its acceptance by the public, but his training did not allow him to disregard the dangers of water closets as Giblin had tended to do. The Queenborough

\section{Ibid 7 October 1896 .}

126. Ibid 13 October 1896; T.P.P. 1901/5 Appendices $N$ and 0 . 
Board could not wait for the Hobart Corporation to act and in December received an opinion from its counsel in favour of legal action. 127 When informed that legal proceedings would be instituted, the Hobart Corporation sent notices to owners of water closets running into the Wellington Rivulet. ${ }^{128}$ By November 1897 the water closets had been cut off and a man was employed by the Council to keep all rivulets clean: in March 1898 the Central Board of Health noted that the rivulets were in a better state than ever before. 129

No attempt was made to close water closets running into other rivulets. Resistance was thought to be much tougher from owners of water closets running into the Park Street RIvulet and the Glebe Town Board gave no indication of taking up the matter. In evidence given to the Royal Commission of 1901 Milles and Brain mentioned that the dubious legal position of the Council stopped action from being taken. 130 Nevertheless the Royal Commissioners urged the Corporation to tackle the water closet problem. Basing its finding on Sprott's evidence, the report averred that, after the use of cesspits, "nothing is more likely to prejudice the public health" than discharging "the contents of hundreds of water closets into dug-out gutters and sluggish open drains, that wind among private houses and alongside and under public streets". It was recommended that they be converted into properly constructed sewers and thoroughly flushed: if not then water closets "should be forbidden by a by-law of the Corporation".

127. M. 9 December 1896.

128. Ibid $27 \mathrm{July,} 18$ August 1897.

129. Ibid 17 November 1897, 24 March 1898.

130. T.P.P. $1901 / 5$ p.21 and 56. 
TABLE 19 : NUMBER OF WATER CLOSETS IN HOBART

\begin{tabular}{|l|r|r|}
\hline \multicolumn{1}{|c|}{ Location } & 1896 & 1901 \\
\hline Hobart Rivulet & 531 & 521 \\
Derwent River & 194 & 194 \\
Park Street Rivulet & 62 & 62 \\
Melville Street/Elizabeth & 37 & 40 \\
Street Creek & 7 & 3 \\
Wellington Rivulet & 21 & - \\
Irrigation Purposes & 6 & 3 \\
Miscellaneous & $\frac{858}{823}$ \\
Total & & \\
\hline
\end{tabular}

Source: M. 13 October 1896.

$$
\text { T.P.P. } 1901 / 5 \text { p. } 21
$$

By 1901 , then, sanitary reformers had mixed success. Rivulets were cleaned more frequently and the number of water closets running into the Wellington Rivulet, estimated by Bradley to be over 20 in 1895, was reduced to three. ${ }^{131}$ From 1903, as work progressed on the metropolitan drainage scheme, pollution of rivulets by water closets ended. ${ }^{132}$ The rivulets remained a convenient receptacle for other kinds of pollutants and, Sprott thought, "they were still more or less offensive": Sprott wanted "A large comprehensive scheme" to be adopted "to get rid of this menace to health". 133 What Sprott meant was not made clear, but the rivulets, apart from minor works, remained untouched until December 1914. Then, as part of an ambitious scheme for port improvements, work was begun on diverting, the Hobart Rivulet by building a tunnel under Lower Collins Street and the Domain, with an outfall into the Derwent. ${ }^{134}$ This was intended to avoid siltatinn at the mouth of the rivulet and assist the flow of water.

131. M. 27 March 1895.

132. Ibid 9 March 1909 Sprott's 1908 annual report.

133. Ibid.

134. Ibid 12 December 1914. 


\section{c) Metropolitan Drainage}

The benefits that would be derived from the drainage of Hobart had been discussed from time to tume since the Corporation was established. Health Officers Hall and Giblin were very vocal proponents but it was not until Mault's 1886 report on the sanitary condition of Hobart that drainage attracted public interest. ${ }^{135}$ Mault found the water supply provided 65 gallons a day per person, which was more than adequate for a water closet system. He described the features of the six drainage basins of the city and noted the best outfalls. Mault's main recommendations were that water closets be placed in every house; the suburbs of Sandy Bay, Wellington, New Town and Glebe Town should be united with Hobart for sewerage purposes; a large-scale, detalled plan of the city should be prepared, showing all the natural features, every building and the levels of the ground; and the construction of a sewerage system with outfalls into the Derwent, at a cost of about $\hat{\approx} 60,000$. The Mercury thought that such a comprehensive report was needed but felt that Mault underplayed "the cost or practicability" of providing an adequate water supply for flushing purposes and of not justifying the financial impost on ratepayers. 136 The Tasmanian News agreed completely with the report's recommendations and regarded drainage as the most important question of health confronting Hobart. ${ }^{137}$

To encourage debate Mault read an abridged version of his report to the Royal Society. ${ }^{138}$ He received a lukewarm response. W.H. Charpentier claimed that a system of underground drainage

135. T.P.P. $1886 / 47$.

136. M. 3 July 1886.

137. T.N. 23 August 1886.

138. A. Mault, "The Drainage of Hobart", P.P.R.S. . 1886, p.xxivff. 
would cost far more than the $£ 60,000$ estimated by Mault. He estimated it would cost about $£ 48,000$ for excavation and that drains, ventilating pipes, grids, connecting joints, manholes and the labour for pipe laying would add greatly to the total cost. Water closets had not been perfected, continued Charpentier, and sewer gas was a threat to health: the water supply would also be stretched beyond its capacity for domestic use. At a subsequent meeting most members tended to oppose Mault's scheme. ${ }^{139}$ The report was denigrated by the Hobart Local Board of Health. 140 Davies averred that the information in the report was of "the most uncertain character" and the estimates were based "on insufficient information". The water supply in summer was not conducive to underground drainage. For the next 25 years, Davies thought, all that was required was to improve surface drainage with gutters made of smooth stone or cement and to get rid of the existing cobble gutters. It was unanimously resolved that Mault's scheme did not meet "with the approval of this board". Thus in 1886 underground drainage was not popular. The serious typhoid epidemic of 1887 was instrumental in changing attitudes. The most dramatic reversal of opinion was by George Davies. In June Davies moved that the Council seek power from Parliament to borrow $£ 100,000$ for a sewerage scheme. ${ }^{141}$ He said that for too long the citizens of Hobart had paid scant attention to sanitary precautions and relied on the healthy climate as a barrier to disease. The typhoid epidemic exposed this "delusion". He blamed "the very defective system of drainage" for contributing

139. Ibid p.xl ff.

140. M. 18 September 1886.

141. Ibid 7 June, 14 June 1887. 
"towards the continuance of this dreadful epidemic which has deprived us of so many of our rising young men ...." The motion was passed. In July a deputation waited on Premier Fysh seeking support for the motion. Mayor Harbottle claimed that since the typhoid outbreak drainage had "received greater attention than it would at any other time" and public support for it was growing Davies asserted that Hobart had received little money from the Government since responsible government began and as the Government benefited from the revenue generated by tourists visiting Hobart, should help make the city "as perfect as possible from a sanitary point of view". Fysh replied that it was a question of "the principle of local self-government as opposed to centralisation": as the drainage scheme would only benefit Hobart, then Hobart had to finance the scheme. In August Davies tried to persuade the House of Assembly to vote $£ 50,000$ for the improvement of the sanitary condition of Hobart. ${ }^{142}$ He quoted figures showing that from 1883 to 1886 Hobart and Launceston paid one-third of real estate duty but received only one-seventh of the expenditure on public works and argued that the Government should give more attention to urban needs. Members of country districts, led by the Minister of Lands Edward Braddon, were unmoved and the motion was defeated.

Despite Parliament's intransigence, it was increasingly accepted by the people of Hobart that drainage of the city was imperative if typhoid was to be avoided. In 1889 and 1890 the Local Boards of Health of Hobart and surrounding suburbs held conferences on drainage with the Central Board of Health but no unanimity on what scheme to adopt was reached. ${ }^{143}$ In early

142. Ibid $11 \mathrm{July,} 12$ August 1887.

143. T.P.P. 1889/38; M. 30 September, 1 October 1890. 
1891 a particularly severe typhoid epidemic resulted in metropolitan drainage being taken up with unprecedented vigour. Public meetings pronounced in favour of it. Members of the Women's Sanitary Association travelled the city seeking signatures for a petition demanding "immediate legislation" to establish a Metropolitan Drainage Board, which would make plans and surveys for a metropolitan drainage area including Hobart and suburbs and would construct it as soon as possible. ${ }^{144}$ 5,736 women signed the petition, which was presented to Parliament on 15 September 1891. The petition and the typhoid epidemic convinced Parliament that drainage was necessary and the Metropolitan Drainage Act 1891 was passed. The main function of the Metropolitan Drainage Board was to prepare plans and estimates for the sewerage and drainage of the metropolitan area, which included the city of Hobart, the towns of Glebe and Mt. Stuart, New Town, and parts of the Local Boards of Health of Glenorchy and Queenborough. Representatives of each local authority within the metropolitan area and nominees of the Government were members of the Metropolitan Drainage Board. (M.D.B.) $)^{145}$ Philip Fysh was chairman and Alfred Mault was Engineering Inspector.

From 1892 to 1896 there was little progress but much bickering amongst members of the M.D.B. Mault was still attached to the Central Board of Health and lacked the clerical assistance to complete the basic survey work. In October 1892 he prepared an interim report outlining three types of sewage disposal: an Irrigation farm, purification of sewage by chemical treatment and discharging sewage into the Derwent without treatment. ${ }^{146}$

144. T.P.P. 1891/p.167.

145. M. 23 January 1892 .

146. T.P.P. 1892/127; see also Mault, "Remarks Upon the Disposal of the Sewage of Hobart", P.P.R.S.T. 1893, p.188-193. 
Mault favoured untreated discharge into the Derwent because it was the least expensive and a negligible threat to health. In November, on a motion by Edward Giblin, this option was adopted by the Board. 147 The decision received heated opposition. The Mercury claimed it was contrary to accepted practice in England and the shocking state of the Thames was proof of its deleterious effects. ${ }^{148}$ The currents of the Derwent were too variable and the beaches of Sandy Bay and Long Point would soon be polluted, thereby threatening health. The Mercury insisted that sewage be purified. The Tamar, it continued, was completely spoiled by the deposit of unpurified sewage and drew a connection between this and the higher number of typhoid cases in Launceston than Hobart. William Perkins, as we know a member of the Sanitary Asosciation and the Central Board of Health, said he would "never consent" to the pollution of the Derwent by this "costly and inadequate" scheme. 149 It would destroy the sea, "the lung of the city", and the fishing industry. Mault was also personally attacked. In 1893, after Mault completed a preliminary report on house drainage, the Mercury dismissed it "as a scheme of primitive simplicity .... put forward in a glib sort of way, by a gentleman who has won more fame by his failures than his successes ..." 150 This was a snide reference to Mault's surveys for the Derwent Valley railway, for which he was criticised by a Royal Commission in $1886 .^{151}$

The Mercury kept agitating for "a clear, unlimited, independent" report on Mault's plans to restore public confidence in

147. M. 15 November 1892 .

148. Ibid 19 November 1892.

149. Ibid 29 November 1892.

150. Ibid 31 August 1893.

151. A.D.B., v.5, p.229. 
the drainage scheme. ${ }^{152}$ In September 1895 C. Napier Bell was

appointed by the M.D.B. and the Mercury applauded the decision. ${ }^{153}$ Bell was an "eminent engineer" and "an authority on all matters pertaining to sanitary science". He had worked on drainage schemes in Dunedin, Christchurch and New South Wales, and on harbour works and river improvements in Tasmania. Bell's report was completed in December. ${ }^{154}$ He considered Mault's plans to be "an excellent survey of the city and suburbs". He made only two alterations. He raised Mault's estimates by 10 percent and favoured one outfall instead of two. Bell argued that the discharge of sewage into the Derwent with the present population of 32,000 would not result in pollution, nor would an estimated population of 53,000 in 50 years. Bell favoured an outlet at Macquarie Point but "popular feeling" was against it and demanded that sewage be carried as far away as possible. Hence he suggested the more expensive outfall at One Tree Point. Mault saw Bell's report as a vindication of his work. ${ }^{155}$ As Bell had scotched any notion of pollution, Mault regarded the additional expense of One Tree Point as unwarranted: he still advocated two outlets, at Macquarie and Battery Points. The Mercury, slightly mollified by Bell's report, favoured One Tree Point. ${ }^{156}$ On 6 January 1896 the M.D.B., reduced by the withdrawal of Queenborough and South Glenorchy, voted for Mault's scheme. ${ }^{157}$ Bell had allayed the fears of members that the Derwent would be polluted.

152. M. 15 June 1895 .

153. Ibid 1 November, 9 December 1895.

154. T.P.P. 1896/9.

155. Ibid Mault's addendum to Bell's report.

156. M. 12 December 1895.

157. Ibid 7 January 1896. 
The cost of adopting the Macquarie Point outfall was $£ 70,000$; if One Tree Point was adopted pumping of sewage would be required and the cost would be much higher. Moreover the scheme could be extended to One Tree Point later as the need arose.

Instead of stifling debate, the decision intensified opposition to the drainage scheme, mainly on health and financial grounds. Henry Tottenham, for example, argued that Mault and Bell had not adduced sufficient evidence to prove that bacterial germs were destroyed by passing through sewers or by discharging into sea water and that the water supply was inadequate to ensure water closets functioned properly. ${ }^{158}$ The Queenborough Town Board opposed the scheme for similar reasons, while members of the Women's Sanitary Association now appeared to be divided on the issue. 159 In August 1896 a deputation of "property-owners and taxpayers" waited on the Treasurer and the Mayor to object to further money being provided for plans for the drainage scheme. The deputation argued that the time was inopportune for a costly drainage scheme because ratepayers were already heavily taxed, the pan system had been improved and the health of the city was good. On 2, September Parliament debated whether further money should be granted to complete the plans. 160 Strong criticism of Mault and the scientific validity of his plans emerged during debate. In defending Mault and the scheme, Edward Mulcahy said opposition to the M.D.B. originated from a minority of property owners, who did not want to pay more rates. This opposition threatened the reputation of Hobart as a sanatorium because defective

\footnotetext{
158. Ibid 17 January, 3 June 1896.

159. Ibid 6 June, 4 March 1896.

160. Ibid 25 August 1896; M. 3 September 1896.
} 
drainage was the source of disease. By a vote of 19 to 10 the money was granted.

Although still facing opposition within and without the M.D.B., Mault completed a detailed report on the outfall area with plans and sections by May 1898. John Bradley, whose reservations about the drainage scheme had been overcome, moved that a bill be prepared providing for "the completion of the surveys and plans and the carrying out of the works necessary for effectually draining the whole metropolitan drainage area". 161 Gregory Sprott, now a member of the M.D.B., made an impassioned speech in favour of drainage, answering all the arguments raised against it. 162 The water supply of Sydney, which had drainage, was between 32 and 42 gallons per head but Hobart's water supply, even in the driest season, was never as low. The "patchwork system" of repairing defective drainage was "a costly affair to property owners" and was not of "a permanent benefit": in the long run the proposed drainage scheme would save property owners money and add to the value of their properties. People were careless with pans: the drainage scheme "must be made as automatic as possible so that people cannot be dirty". He ventured his "medical opinion and reputation .... that unless we get a proper sewerage system for the city the citizens can never hope to get rid of typhoid. It is the scourge of Hobart". Sprott then compared the typhoid death rate of Hobart and Sydney and showed that since Sydney had been drained typhoid had steadily declined. The motion was unanimously passed.

161. Ibid 6 May 1898.

162. Ibid; extracts from the speech were included in T.P.P. 1898/53. 
The new Metropolitan Drainage Bill was submitted to Parliament in July. 163 Philip Fysh, in an eloquent opening, said metropolitan drainage was intended to make Hobart "the healthiest city in the Southern hemisphere" and other supporters spoke in a similar vein. When the clause relating to a poll of ratepayers was debated, disagreement arose over what majority of votes was acceptable. 164 Edward Mulcahy argued that property owners, the main opponents of the scheme, had "an enormous preponderance" over occupiers at a ratio of seven to one and, to achieve equity, a bare majority was substituted for a two-thirds majority. In the Legislative Council 123 house and landholders petitioned against the bill. ${ }^{165}$ The petition embodied three major criticisms - no provision was made for purification of sewage, no "reliable" estimate of the ultimate cost of the scheme had been given and the water supply was inadequate. The petitioners wanted a two-thirds majority. The Legislative Council made some amendments favourable to property uwners but Lhese largely failed to survive review in the House of Assembly. ${ }^{166}$ Thus the new Act empowered a reconstituted M.D.B. to complete the plans and submit them to a poll of ratepayers for their assent before construction could begin. ${ }^{167}$ The Tasmanian News described the old M.D.B. as "a huge failure" because of "the half-heartedness of members genera11y, and the direct antagonism of certain members". 168 Of the 14 members of the new M.D.B., at least eight were committed supporters of metropolitan drainage. ${ }^{169}$ Davies was chairman.

163. M. 6 July 1898

164. Ibid 14 July 1898.

165. Ibid 4, 5 August 1898.

166. Ibid 1 October 1898.

167. T.P.P. $1898 / 23$.

168. T.N. 6 December 1898; see also M. 31 March 1904 for a letter by Mulcahy.

169. M. 19 January 1899 for the first meeting. 
Two members C.H. Grant, who had been a member from 1892, and R.C. Patterson were engineers. 170 Patterson, a civil engineer educated at King's College London, had been deputy engineer-inchief in South Australia.

The new M.D.B. did all it could to win public support before submitting any scheme to a pol1. To assuage fears that the water supply was insufficient the view of Robert Milles, the Corporation's Director of Waterworks, was sought: he thought it was ample but more reservoirs would be needed in the future. ${ }^{171}$ The report was sent to Charles St. John David, Launceston's City Surveyor, who endorsed Milles's conclusion. The opinions of Napier Bell and W. Thwaites, engineer of the Melbourne Metropolitan Board of Works, were also sought, both of whom thought the water supply could easily sustain a drainage scheme. In order to establish a more accurate estimate of the cost of the scheme the M.D.B. decided to call for tenders for a section of the drainage area to see if Mault's estımates "could be relied upon". 172 The lowest tender was "greatly in excess" of Mault's. This was used as evidence of Mault's unsuitability for the post of engineer and not long afterwards his services were "dispensed with". Given Mault's unpopularity, whether justified or not, the end of his association with the M.D.B. was probably a pre-condition for public acceptance of the drainage scheme.

Property owners, who had all along opposed the drainage scheme and the nominee M.D.B., formed, as we have seen, the Hobart

170. S. and B. Bennett, Biographical Register of the Tasmanian Parliament 1851-1960, (Canberra, 1980), p.70 and 130-1.

171. M. 2 March, 24 March 1899.

172. Ibid 4 October 1899, 5 November 1901. 
and Suburban Property Owners Association in July 1901, and attempted to use Mault's departure as an indication that the M.D.B. had failed. It demanded that no more money be granted to the board and that a poll of ratepayers be immediately held. ${ }^{173}$ By a majority of one the House of Assembly disagreed with these demands: $\{2,000$ was voted to the M.D.B. to appoint a new engineer to report on the drainage scheme. ${ }^{174}$ In early 1902 Davies resigned as chairman because of other responsibilities and Patterson replaced him. 175 Thus for the first time a trained engineer headed the M.D.B. Later in 1902 an experienced engineer from the mainland, E.H. Wilkinson, was appointed as engineer to the board and by December had completed a new report on the drainage scheme. ${ }^{176}$ He estimated the cost of his scheme at $\$ 79,341$, requiring a rate of $6 \mathrm{~d}$. in the pound for sewers. He recommended Macquarie Point as the outfall and septic tanks to purify sewage. The Derwent, he thought, would not be polluted as the amount of sewage would be comparatively small in proportion to the volume of water. The Mercury, which had long advocated septic tanks, supported Wilkinson's scheme. ${ }^{177}$ In January 1903 Wilkinson reported on the cost of house connections. ${ }^{178}$ This cost was more difficult to estimate because buildings, depending on their size, were assessed at different annual values and more expensive fittings

173. T.N. $16 \mathrm{July}, 22$ October 1901; M. 5 November 1901.

174. M. 14 November 1901.

175. Ibid 1 February 1902.

176. Ibid 23, 30 December 1902; see also E.H. Wilkinson, "Sewage Purification and Disposal", P.P.R.S.T., 1902, p.100-5 and J. Jamieson, "Typhoid in Hobart and Me1bourne, and the Influence of Drainage on its Prevalence", P.P.R.S.T., 1902, p.95-99.

177. M. 31 December 1902.

178. Ibid 14 January 1903. 
for water closets would be used for larger buildings than for homes. He considered that house connections would cost an average of $£ 12$ per house or a total of $£ 72,000$. To enable those owners, who "from poverty or stress of circumstances" were unable to afford this expenditure, Wilkinson suggested that "the deferred payment system" be employed, whereby payment would be spread over a number of years as was done in Melbourne and Sydney. The total cost of the scheme was thus $£ 154,341$, including $£ 3,000$ for engineering purposes.

Wilkinson's estimates were scrutinised by a committee of the M.D.B., comprised of Patterson and Aldermen Freeman and Paton, who found them to be "wonderfully reliable". 179 Their estimate was $£ 2,000$ less than Wilkınson's estimate but his was accepted by the M.D.B. It was also resolved that property owners pay for house connections and that deferred payments be adopted. The Mercury was satisfied that "every possible precaution" had been taken with the estımates and wrote a series of editorials eulogising Wilkinson's scheme. "After many years of curious inefficrency and muddle", it wrote, the M.D.B. had gained "the confidence and even the respect" of ratepayers by the practical men on it and the safeguards taken. 180 'Both the Tasmanian News and the Clipper thought the drainage scheme could be accepted with safety. 181

The M.D.B. felt the time was opportune to hold a poll and its members began a public relations campaign to convince ratepayers to vote for the scheme. At five public meetings

179. $\quad$ Ibid 28 January 1903.
180. $\frac{\text { Ibid }}{19}$ February 1903.
181. $\quad$ T.N. 29 January 1903; Cl. 21 February 1903.


in different parts of the city Patterson, Wilkinson and Sprott gave reasoned speeches emphasising the advantages of the scheme. ${ }^{182}$ On 26 February, at the last meeting, speakers also included the Premier N.E. Lewis and the Bishop of Tasmania Dr. John Mercer. They stressed the drop in tourists due to the disease generated by defective drainage. Lewis pointed out that New Zealand, which competed with Tasmania for tourists, was spending much money on drainage: the drainage scheme, he said, would remove the "reproach" that Hobart was the "worst drained city in Australasia". The Tasmanian Tourist Association gave its public support to the scheme. ${ }^{183}$ The poll was held on 3 March: 3268 votes were cast for the scheme and 1240 against. ${ }^{184}$ A majority of voters at every level of the one to seven vote scale supported the scheme. The Tasmanian News regarded it as an "emphatic" vote of confidence in the M.D.B. ${ }^{185}$ The majority, wrote the Mercury, was "larger than even the most sanguine expected". 186 It was "unquestionably" due to the success of the public meetings in clarifying details of the scheme. The adoption of septic tanks, the public support of influential men, the moderate cost of the scheme as estimated by Wilkinson and, above all, the promise of a reduction in typhoid contributed to the affirmative vote.

At last the M.D.B. could begin work but there remained an undercurrent of resistance to the scheme, mainly from the Property Owners Association. It established a vigilance committee

182. M. 17, 19, 21, 25, 27 February 1903 for meetings at North Hobart, West Hobart, Battery Point, Cascades and the Town Hall respectively.

183. Ibid 3 March 1903.

184. Ibid 4 March 1903.

185. T.N. 5 March 1903.

186. M. 4 March 1903. 
to watch the M.D.B.'s proceedings and aimed to keep the cost of the scheme as low as possible. ${ }^{187}$ The board, however, refused to skimp on the cost. In November 1905 J.C. Paton, on behalf of the Property Owners Association, charged that too high a standard in house connections was being enforced: fittings were too expensive and he wanted the standard to be relaxed. ${ }^{188}$ The redoubtable Patterson replied that "by far the most important part of the system of underground drainage was the establishment of proper house connections". The board ensured that plumbers with suitable qualifications and experience were employed to do sanitary work. If the house connections, he continued, were allowed to be made with shoddy material, or by the agency of unauthorised and incompetent workmen, then they most certainly became a standing menace to the public health .... The great danger to be apprehended from house connections improperly made was the probability of gas or foul air from sewers penetrating into the interior of dwellings and so leading to the propagation of the very diseases it was the aim of the board to annihilate, or, at any rate, to suppress as far as possible.

The enforcement of high standards of sanitary plumbing was a major achievement of the M.D.B. In addition to the cost of the scheme, the use of septic tanks remained a contentious issue. In response to rumours that a properly equipped septic tank system was not going to be constructed, Thomas Kendall,

187. Ibid 4 April 1906.

188. Ibid 22 November 1905. 
of the Sydney Metropolitan Board of Works, was appointed to assess the scheme. 189

Kendall's report did not condemn the M.D.B.'s septic tank system but he did offer improvements. 190 He recommended that the septic tanks be enlarged and that a series of upward filtration beds be connected: this would provided 70 percent purification. He thought the tanks should be covered and allowance made for a three gallon flush for water closets. The Mercury was pacified but not entirely happy. ${ }^{191}$ It watched very closely to ensure that the recommendations were adopted. Dawson, the new engineer to the M.D.B., agreed with Kendall that the septic tanks should be covered and that the existing tanks needed alteration to achieve greater purification. 192 Patterson adhered to his belief that crude sewage could be discharged into the Derwent without harmful effects and that septic tanks were "costly and unnecessary". 193 They were, he admitted, "only adopted by the board out of deference to public sentiment, and with the view of conciliating the Mercury, without whose assistance the drainage scheme could not have been carried at the polls". Kendall's improvements were carried out. In January 1907 Patterson invited "a representative" number of citizens to inspect the septic tanks which had been in operation for 12 months and took sewage from 824 closets and 728 separate premises. 194 Three tanks had been constructed but only one was used and it was

189. Ibid 17, 20 August 1904.

190. Ibid 21, 24 September 1904; T.N. 21 September 1904.

191. M. 26 September 1904.

192. Ibid 16 November 1904.

193. Ibid 7 December 1904.

194. Ibid 5 January 1907. 
117 feet eight inches long, 25 feet eight inches wide, with an average depth of eight feet eight inches. H.R. Nicholls, editor of the Mercury, who had led "the crusade" for septic tanks, was present and seemed satisfied. The visit, thought the Tasmanian News, allayed "a great deal of the doubt previously existing as to the efficacy of this process". ${ }^{195}$ However, as sewage from more houses entered the septic tanks, the removal of sludge became a serious problem. In February 1910 the fourth and most capable chief engineer used by the M.D.B., G.W. Thom, thought it preferable "to discharge the sewage after screening direct into the estuary" than to remove the sludge onto a barge and then discharge it into deep water. 196

Objection to this proposal by the Marine Board led to a joint committee of members of the Marine Board and the M.D.B. to establish whether untreated sewage "can be safely and otherwise satisfactorily discharged into the estuary at Macquarie Point". 197 In July 1910, after considering the evidence of Thom and the harbour-master, the joint committee recommended that the septic tanks be abandoned, that the outfall pipe be extended a further 300 feet to 426 feet into deep water and that raw sewage be discharged into the Derwent. ${ }^{198}$ It was argued that the cost of removing sludge was too high, the land occupied by the septic tanks could be better used by the Railway Department, and the volume of water would dilute the sewage and not pollute the river. Sprott was not opposed to the recommendations but

$$
\begin{aligned}
& \text { 195. T.N. } 9 \text { January } 1907 . \\
& \text { 196. M. } 16 \text { February } 1910 . \\
& \text { 197: } \text { Ibid } 23 \text { June } 1910 . \\
& \text { 198. } \quad \text { Ibid } 20 \text { July } 1910 .
\end{aligned}
$$


registered his opinion that the septic tank system failed only "because it had never been properly carried out, and they did not wish to go to the expense of giving it a thorough trial". This view was shared by the Mercury. 199

The recommendations were implemented and proved successful, although in September 1911 the M.D.B. decided to instal a sewage disintegrator at the main outfall to further break-up solids. 200 The disintegrator worked well. F.D. Lord, who represented Queenborough on the M.D.B., a suburb very concerned to prevent defilement of the Derwent, said there was now "no fear of our beautiful river, being polluted". ${ }^{201}$ Even the Mercury was enthusiastic and felt that the disintegrator "proved perfectly successful as no objectionable refuse is now carried on to the shores and there is no offence to shipping". 202 Lingering doubts were vanquished in November 1912 by Sprott, who had returned from a trip abroad. 203 After seeking the views of leading sanitary engineers, he concluded that "provided our outfall at Macquarie Point is extended enough and into deep water, we need have little fear either of polluting the river or causing injury to the public health".

At the end of December 1912, having completed the drainage scheme, the M.D.B. dissolved and transferred control of the sewerage of Hobart to the City Council. 204 That the M.D.B. had achleved its major objective was shown at its last meeting when

199. for example see Ibid 6 June 1910.

200. Ibid 20 September 1911.

201. Ibid 7 February 1912.

202. Ibid 13 March 1912.

203. Ibid 26 November 1912.

204. Ibid 31 December 1902; Hobart Sewerage Act 1912. 
Sprott tabled figures demonstrating an unmistakeable decline in typhoid from 1903 to 1912.205 This success converted critics. The Mercury, while admitting that at $£ 185,000$, apart from house connections, the scheme cost more than twice that estimated when work began, thought that the reduced incidence of disease was worth the cost. 206 Alfred Crisp, a very large property owner and originally an opponent of drainage, said that "As a propertyowner who had had to bear heavy expense re connection with the drainage, he would not for anything revert to the old and barbarous conditions that previously existed". 207 He exuded pride at "such a fine system of drainage. Besides the convenience, it had increased the value of their property threefold .... Besides this, they had their good name, and this was an attraction for tourists". 208 Thus private and public interest converged. Residents of Queenborough, which had withdrawn from the scheme at an early stage, wanted to enjoy the benefits of drainage and sought inclusion in the drainage area: by December 1914, after Queenborough amalgamated with Hobart, a detailed survey of the area to be drained was well under way. 209

By the end of 1914 it can be fairly concluded that notable strides had been made in the removal of wastes. The drainage scheme was the most shining achievement. While the low percentage of houses enjoying regular refuse removal provided less cause for celebration, the system was gradually being more widely adopted.

205. M. 31 December 1912 .

206. Ibid.

207. Ibid 4 April 1911.

208. Ibid 31 December 1912.

209. IbId 23 June 1913, 8 December 1914. 
Consequent1y the incidence of typhoid, the disease which had spawned the sanitary reform movement of the late 1880 s and early 1890s, had been greatly reduced and the death rate from it had become negligible. 210 (Tables 20 and 21) 
TABLE 20 : CITY OF HOBART - CASES AND DEATHS OF TYPHOID FEVER RECORDED IN MEDICAL OFFICER'S OF HEALTH ANNUAL REPORTS.

\begin{tabular}{|c|c|c|c|c|c|}
\hline Year & $\begin{array}{c}\text { Number of } \\
\text { Cases }\end{array}$ & $\begin{array}{c}\text { Number of } \\
\text { Deaths }\end{array}$ & $\begin{array}{l}\text { Death } \\
\text { Rate } \\
\text { Per } 10,000\end{array}$ & $\begin{array}{c}\text { Attack } \\
\text { Rate } \\
\text { Per } 10,000\end{array}$ & $\begin{array}{c}\text { Case } \\
\text { Mortality } \\
\text { Rate }\end{array}$ \\
\hline 1896 & 66 & 11 & - & - & - \\
\hline 1897 & 106 & 10 & 3.50 & 36.95 & 9.48 \\
\hline 1898 & 246 & 24 & 8.10 & 86.70 & 9.38 \\
\hline 1899 & 63 & 5 & 1.64 & 20.28 & 7.94 \\
\hline 1900 & 61 & 5 & 1.60 & 19.68 & 8.19 \\
\hline 1901 & 68 & 5 & 2.03 & 27.58 & 7.35 \\
\hline 1902 & 62 & 5 & 2.03 & 25.14 & 8.06 \\
\hline 1903 & 61 & 8 & 3.25 & 24.74 & 13.11 \\
\hline 1904 & 47 & 6 & 2.43 & 19.06 & 12.77 \\
\hline 1905 & 40 & 9 & 3.65 & 16.22 & 22.70 \\
\hline 1906 & 50 & 7 & 2.84 & 20.28 & 14.00 \\
\hline 1907 & 45 & 6 & 2.43 & 18.25 & 13.36 \\
\hline 1908 & 71 & 10 & 3.06 & 21.70 & 14.09 \\
\hline 1909 & 68 & 5 & 1.53 & 20.78 & 7.35 \\
\hline 1910 & 33 & 3 & 0.90 & 9.93 & 9.09 \\
\hline 1911 & 21 & 2 & 0.70 & 7.33 & 9.52. \\
\hline 1912 & 10 & 2 & 0.72 & 3.61 & 20.00 \\
\hline 1913 & 19 & 3 & 1.08 & 6.86 & 15.79 \\
\hline 1914 & 22 & 2 & 0.63 & 6.88 & 9.09 \\
\hline
\end{tabular}

Source: J.H.L. Cumpston and F. MacCallum, The History of the Intestinal Infections (and Typhus Fever) in Australia 1788-1923, (Melbourne, 1927), p.736. 
TABLE 21 : DEATHS FROM TYPHOID FEVER IN HOBART REGISTRATION DISTRICT AND RATE PER 100,000

\begin{tabular}{|c|c|c|}
\hline Year & Deaths & Rate \\
\hline 1886 & 9 & 30 \\
\hline 1887 & 70 & 224 \\
\hline .1888 & 37 & 109 \\
\hline 1889 & 41 & 117 \\
\hline 1890 & 17 & 52 \\
\hline 1891 & 57 & 168 \\
\hline 1892 & 20 & 58 \\
\hline 1893 & 9 & 26 \\
\hline 1894 & 17 & 48 \\
\hline 1895 & 21 & 58 \\
\hline 1896 & 20 & 54 \\
\hline 1897 & 11 & 29 \\
\hline 1898 & 31 & 78 \\
\hline 1899 & 7 & 17 \\
\hline 1900 & 7 & 20 \\
\hline 1901 & 8 & 23 \\
\hline 1902 & 8 & 23 \\
\hline 1903 & 13 & 37 \\
\hline 1904 & 8 & 23 \\
\hline 1905 & 11 & 31 \\
\hline 1906 & 8 & 23 \\
\hline 1907 & 10 & 28 \\
\hline 1908 & 11 & 27 \\
\hline 1909 & 10 & 26 \\
\hline 1910 & 5 & 13 \\
\hline 1911 & 6 & 16 \\
\hline 1912 & 4 & 11 \\
\hline 1913 & 6 & 15 \\
\hline 1914 & 3 & 8 \\
\hline
\end{tabular}

Source: J.H.L. Cumpston and F. MacCallum, The History of the Intestinal Infections (and Typhus Fever) In Australia 1788-1923, (Melbourne, 1927), p.729. 


\section{CHAPTER NINE}

\section{VESTED INTERESTS}

In Chapter Five the hindrance caused by vested interests to the Launceston Corporation's enforcement of sanitary legislation was examined. Special interests associated with housing, noxious trades, cemeteries and factories were also encountered by the Hobart Corporation in its attempt to improve the health and convenience of urban life.

\section{a) Housing}

In 1881 the Police Amendment Act empowered the Hobart Corporation to order the demolition or repair of dilapidated buildings. It was not a great success. By May 1885 only 61 buildings had elther been demolished or, more usually, repaired. ${ }^{1}$ In 1884 the Hobart Building Act, based on the Launceston Building Act 1869, was passed to ensure that housing in the future did not fall to the sub-standard level of the past. Under the Act the Council appointed Richard Bastow as Building Surveyor in early 1885. Bastow had come to Hobart from Manchester because of his wife's health. ${ }^{2}$ He worked for the Health Department of the Manchester City Council for 10 years: he prepared sanitary maps of the city and received high praise from Manchester's Mayor and Health Officer. Bastow discharged his duties as Building Surveyor with fairness and tact. In March 1885 he reported that he had been surveying properties which had begun to be built after the passage of the Building Act but before he was appointed. ${ }^{3}$ Many

1. M. 12 May 1885 .

2. T.N. 20 February 1889; see W.F. Ward, "Water and Typhoid", P.P.R.S.T., 1885 p.C.xxv for Bastow's work In Manchester.

3. M. 3 March 1885; see also M.C.C. 16/58 for Bastow's letterbook. 
properties did not conform to the Act but had reached an advanced stage. To demand conformity would have resulted "in great hardship" and he decided not to enforce the law rigorously because it might jeopardise subsequent relations with builders. Bastow had received 12 notices of buildings about to be constructed: only four satisfied him. He suggested changes and the architects and builders, except one, "readily acquiesced in the necessary alterations", which usually were the replacement of wooden walls by brick walls. Bastow felt his work was "fraught with importance" to the best interests of Hobart. It would result "in a much better class of buildings being erected; in better sanitary conditions; in a higher rateable value; in an increased amount of work for builders, and the fees resulting therefrom will speedily more than cover the expenses entailed; it will also pave the way for (if it does not include) other and highly important sanitary measures".

Not everyone was as sanguine about the benefits of the Building Act. Alderman G.S. Crouch, who was also Secretary to the Hobart Building Society, regarded it as "a little too harsh and arbitrary". 4 The President of the Hobart Building Society Peter Facy felt that the Act "would have an injurious effect on the business of the society". 5 The working classes, he claimed, should be permitted to build "what kind of house they please" and the fire limit was "too large". In August 1885, at a meetıng held on behalf of 350 property owners, A.L. Lambert

4. M. 12 May 1885 .

5. Ibid $15 \mathrm{July}$ 1885; G. Young, "The Hobart Building Society 1874-1971", unpublished B.A. Hons. Thesis, University of Tasmania, 1971 for the activitıes of the Society. 
asserted that "there had been more hostility" in the short time the Act had been in operation in Hobart than in 15 years in Launceston. 6 J. Dean, referring to partition walls, said "an Englishman's house was his castle and .... no-one had any right to come and dictate what the thickness of his walls inside his house should be". The charging of fees also came under attack. 7 In 1886 pressure from building interests resulted in a new Building Act being passed, which included clauses relating to foundations, the distance between dwellings made of wood, the thickness of party walls and "the general appearance of the city". 8 Building fees, however, were retained. In December, 1886 at the municipal elections, candidates representing the building trade attacked fees and announced their intention of seeking Bastow's dismissal, believing that there should be no restriction on builders. 9 The Mercury dissented: regulation was necessary to stop speculators building in "the cheap and nasty method" and not intended to hamper honest builders. The Council's duty, "both morally and legally", was to ensure houses were safe and healthy and not eyesores or dwellings "unfit for human habitation". Some landlords rented buildings "until they actually tumble to pieces from sheer rottenness" and Bastow's dismissal would only "serve what may be fairly called private ends". Continued agitation by the building trade ultimately resulted in the abolition of fees in August 1887 and Bastow resigned soon after. 10

6. $\quad$ M. 6 August 1885; T.N. 6 August 1885 .

7. M. 21 July 1885.

8. Ibid 3, 17 December 1886.

9. Ibid 7, 21, 22 December 1886.

10. Ibid 16 August, 6 December 1887 . 
The failure of the Corporation to deal with insanitary housing often incurred criticism. In March 1886 the Tasmanian News claimed that there were "far too many hovels yet remaining in the City, which are altogether unfit for human habitation" and were not demolished because of "the influence of wealthy ownership". 11 In 1891 it thought that "much of the disease which stalks abroad .... can be traced to dirty, illventilated dwellings" and criticized the ineffective building regulations. ${ }^{12}$ In 1892, after citing numerous examples of dirty and undrained houses, it wrote that if the Health Officer visited sections of Hobart "he would find dwellings occupied by the lower classes which are overcrowded, unwholesome and otherwise in a deplorable state, and where there is a total deficiency in sleepıng accommodation". 13 The effect on children raised in such "noxious physical agencies" was a deterioration "in physical organization and general health" and the abandonment of "the decencies of life and .... a precocious development of all the propensities of their animal nature". Also the rents were "altogether out of proportion to the healthful accommodation they afford". The Clipper added to this bleak picture. It claimed that if a man became sick, could not work and therefore could not pay the high rent for the hovel his family had to inhabit, they were evicted and forced to find shelter in worse housing with other luckless families. ${ }^{14}$ Landlords rarely provided baths or the "ordinary accessories of civilisation" for tenants, who had no incentive to be clean: even by 1914 "the majority of houses In the city had no baths". 15

11. T.N. 18 March 1886.

12. Ibid 14 May 1891.

13. Ibid 29 April 1892.

14. Cl. 21 September 1895.

15. Ibid 25 January, 12 December 1896; M. 2 June 1914. 
Even the organ of property owners, the Register and Property Investors Guide, was critical of the state of dwellings. The Building Act, it wrote in January 1896, was easily evadedand did not go "far enough". 16 The Corporation rarely enforced by-laws and lacked the "moral firmness" to ensure owners kept properties in good order. ${ }^{17}$ The Building Act defined the type of building to be built in certain areas but did not prevent "anyone erecting what peculiar style of architecture may be deemed unique, regardless of uniformity with the surroundings". The guiding principle should be "'the greatest good for the greatest number', an excellent reason why individuals should be, to a certain extent, constrained in their action and not permitted to do what is likely to lower the value of a neighbour's property". As it was "in the immediate suburbs of Hobart mere hovels exist, not flourish, they being absolutely unfit for human habitation, yet they are permitted to remain, not only an eyesore, but .... [insanitary], therefore obviously detrimental to the locality around them by reducing the value of adjacent land and buildings". These hovels should be removed not in an "arbitrary" way but "in a judicious and considerate manner" and "at the same time firmly, so as to improve the character and sanitary condition of the neighbourhood and perhaps lead to the building of better houses ....". The suggestions were made "in the interests of the general community and property holders in particular" with the aim "to see Hobart present a better appearance ...."

16. R.P.I.G. 14 January 1896.

17. Ibid 25 November 1896. 
The Register is quoted at length because it was one of the few examples before 1900 of a section of the building and real estate community referring to insanitary housing. It indicated that property owners were not a homogeneous group. The assumption that underlay most discussion of insanitary housing was that property owners refused to spend money on improving the condition of their properties unless ordered to by the Council. The Register had a wider perspective. It acknowledged that bad housing existed but was not concerned for the people who lived in the hovels: the motive was economic not health. The publishers of the Register, R.J. Rogers and his son Edwin, were real estate agents and had a vested interest in improving the physical environment of the city and housing to encourage more people to settle in Hobart and buy houses. Hence Edwin's involvement with the Sanitary Association. This aim conflicted with the inaction of those landlords who only wanted to collect rents from tenants and would not improve their dilapidated properties while people were prepared to live in them.

Aldermen generally gave little attention to insanitary housing between 1886 and 1891. In 1892 Alderman Crouch noted that dilapidated housing was very prevalent. ${ }^{18}$ He spoke of tenements inhabited by the sick and poor in the city that "were unfit for a dog, a pig, or a cow to be put in". He wanted more intensive efforts to improve or condemn buildings. Alderman Smith warned against wholesale demolition. He cited a case of three families living in one three-roomed cottage and claimed such overcrowding was common and would be more widespread if the law was enforced.

18. M. 15 June 1892 . 
Alderman Baily suggested that the Council build houses for the poor at low rent. The Hobart Corporation was too conservative to adopt such schemes in normal times but the depression provided a convenient excuse not to embark on Baily's proposal. Thus, as in Launceston, because housing, of a suitable standard and at a rent that the poor and working classes could afford, was scarce, demolition was sanctioned only in cases of extreme deterioration: ordering repairs was deemed more expedient and the only option if overcrowding was to be avoided.

The poor standard of housing in Hobart was taken up by the Women's Sanitary Association. In September 1892, at the first meeting, Maud Montgomery claimed that

There were courts in Hobart which one would pass without seeıng, so narrow and so dark were the entrances, and they were reeking with impurity, the houses... being quite unfit for human beings to live in .... 19

If landlords, she contınued, were allowed to build "these back to back houses and put up dwellings without paying proper attention to sanitary conditions", Hobart would emulate London, "so far as dirt, misery and diseases were concerned". Before Lady Hamilton's departure from Tasmania in mid-1893 the Women's Sanitary Association had intended to petition Parliament for a Royal Commission into the housing of the poor but did not because of the depression. 20 In September 1893, members of the Women's Sanitary Association, who had formed a Relief Restaurant to provide cheap food for the poor and unemployed, considered co-operating

19. Ibid 15 September 1892.

20. Ibid 31 July 1893. 
with the Benevolent Society in providing cheap housing on a small scale and to form an association "for the erection of improved industrial dwellings". 21 A similar association, the Tasmanian Artizans Dwellings and Land Investment Company, had been formed early in 1888 but, after building four cottages in Upper Macquarie Street, folded. 22 The new Association for Improvement of Dwe11ings of the Working Classes was officially established on 25 September 1893 but it also failed. ${ }^{23}$ Hobart lacked the population base to sustain such schemes. Charitable assistance fell heavily on too few people and the outlay required for housing, even with a predicted nine percent return on investment, was too great, particularly during a depression. Co-operation with the Benevolent Society was more successful. An offer by Alderman John Baily of a quarter of an acre of land between George and Smith Streets, North Hobart, was accepted by the Benevolent Society: the architect gave his advice without charge and the builder provided materials at a cheap rate. By May $1895 \quad 12$ cottages had been built at a cost of $\approx 2,200 .^{24}$ The houses, thought the Mercury, contrasted graphically "with some of the cottages surrounding them for which almost double the rents are asked and obtained". This was the only attempt to grapple with housing provision prior to 1900 and was more a palliative, benefiting a lucky few, than a solution to the housing problem. Housing received more attention from 1901, as we are about to see. In 1901 the Royal Commission on the Municipal Government of Hobart and Suburbs addressed itself to the quality of housing.

21. Ibid 4, 11 September 1893.

22. Ibid 14 December 1888.

23. Ibid 26 September 1893; T.N. 26 September 1893.

24. M. 10 May 1895. 
The evidence of the City Surveyor, R.S. Milles, was instructive. One exchange went thus. 25

1525. Are there any buildings in this City which, in your opinion, in the interests of the public health and for other reasons, should be demolished? Yes, a great number.

1526. Have you advised the Corporation to that effect? Well, every year, more or less, we have had a certain number of buildings that have had to be dealt with, both from the point of view of their being insanitary and of their being improperly constructed. I think that latterly most of the notices given in reference to such buildings have been carried out.

1527. Have you advised the Corporation as to the number of places you think ought to be demolished? No; I have never had occasion to make a recommend-. ation as to the number of buildings I think it necessary to have demolished. 1528. If you did so, the Corporation would have the power to deal with the matter? 0 yes; they have full powers.

1529. And you have not made any such report? No; I could not make a general report unless I was requested to make it.

Thus the Corporation made little attempt to deal with dilapidated and Insanitary houses: superficial repairs were made to houses that should have been demolished. Sprott told the Royal 
Commission that recently by-laws had been passed making it compulsory that a plan of a house with proposed drainage be sent to the City Surveyor because many houses were being built without any form of drainage. ${ }^{26}$ The Royal Commission found that the inspection of buildings was "not conducive to public health and safety" because the powers and duties of the City Surveyor and Health Officer were not clearly defined. If the City Surveyor provided aldermen with thorough reports on all buildings that should be demolished, there was little chance that they would authorise the work. As Edward Mulcahy said if aldermen "enforced the destruction of some of the buildings that were a disgrace to the city they would not get, or could not retain, their seats". 27 In July 1902, in a speech at the Town Hall on "City Improvements", Mulcahy appealed for a new and strengthened Building Act because "in the very heart of the city" were buildings that could not "exist in any other place on earth except China". 28 London and other major cities had wide powers to demolish bulldings and similar powers should be given to the Hobart Corporation. The Clipper thought that the basis upon which rates were levied perpetuated insanitary housing. ${ }^{29}$ The owner of a house in bad condition paid low rates but the citizen, "who beautifies a block by makıng a home on it, is rated up to the hilt". Reversing this system of rating would result in "a vast reform" in the standard of housing.

26. Ibid, p.26; Hobart Gazette 22 January 1901, p.195.

27. M. 31 October 1901 debate on the Royal Commission's report.

28. Ibid 16 July 1902.

29. Cl. 22 August 1903. 
From 1903, as we know, the Corporation became more progressive and aldermen were more inclined towards reform of the physical environment. In July 1903, on the initiative of Alderman Gould, the City Surveyor was instructed to prepare "a list of all the dilapidated and unsightly buildıngs within the city". 30 By December the list was completed. 31 Alderman Moore wanted the owner's names attached to see "who were the men receiving sweating rents from poor people". Notices were given to owners of condemned buildings to appear before the Council on 21 December to "show cause why the buildings should not be dealt with": no-one appeared. 32 In 1904 Corporation initiated repair and demolition of houses underwent its most vigorous phase. The new Health Officer Gerard Smith proved invaluable. He had had "a long experience" of dealing with the housing problem of workers in East London and developed "the deepest sympathy" for their plight, a sympathy he retained for the workers of Hobart. 33 He believed that "the course which is now being taken in demolishing certain Insanitary dwellings will ultımately vastly improve the condition of those workers". There will be, he predicted, "a transitory stage of difficulty to get over, until businessmen of Tasmania discover that money is to be made in Hobart, as in England, by erecting workmen's dwellings". The destruction of "the nests in which disease is bred" and building better quality housing would "raise the general health of workers and their power to resist illness". Later he asserted that "Insanitary and wretched surroundings inevitably

30. M. 30 June, 21 July 1903.

31. Ibid 1 December 1903.

32. Ibid 22 December 1903.

33. T.N. 21 May 1904 letter by Smith. 
drag down men and women anc children towards a lower moral ideal; immorality and vice go along with ill-health and poor physique, which is caused by insanitary dwellings". 34

Smith found that many of the dwellings inhabited by the lower classes were of three rooms and were "very old, being built upon the bare ground, and, having no ventilation to the floors", were "very damp": "Old Hobart was entirely built on this plan, it appears". 35 Sleeping accommodation was totally inadequate. It was "the extremely small size of the average sleeping room in Hobart cottages" that caused most of the disease and immorality. 36 That 5s. to $7 \mathrm{~s} .6 \mathrm{~d}$. per week was paid for these dwellings was "exceedingly unsatisfactory". ${ }^{37}$ Although supported by the majority of aldermen, Smith encountered difficulties. Notices were sent to landlords and "small improvements" were made "to the extent to which will just meet the law in a technical sense, but not sufficient to render the cottages much more habitable". 38 From the beginning of 1904 to June 190540 houses were condemned by the Corporation and 12 voluntarily demolished by property owners. 39 Smith wanted to enforce demolition more stringently but was held back:

Dearly, would I love to be able to order the demolition of hundreds of Hobart cottages but where could the inmates find dwellings? Of all the towns which I have seen under British rule in my considerable

34. Ex. 22 April 1905 article by Smith entitled "Sanitation and Religion".

35. M. 15 August 1905, I May 1906.

36. Ibid 1 May 1906.

37. Ibid 15 August 1905.

38. Ibid 3 May 1905.

39. Ibid 15 August 1905. 
travels, I have touched none so shamefully neglectful of the housing of the poor. My own official duty is to remove insanitary dwellings if they are beyond repair; but it is now [in May 1905] becoming literally impossible to condemn any more, because there are no decent cottages for the poor people to move into at possible rents, and I fear the results of overcrowding will be worse than the existing conditions. 40

To those who blamed him for the existence of hovels Smith replied that "My responsibility ends with my reports and recommendations, and devolves upon the municipality. I disclaim responsibility in the matter of the existenre of these bad cottages, so long as there are no other dwellings for the poor to move into, and there are none". Furthermore in many cases the houses were "almost the sole support of .... owners, poor widows, or others who are past work, and to demolish these, when by any possible means repair can be made to supply a sanitary dwelling, is an action of great severity, one which I cannot bring myself to advise". ${ }^{41}$ Often the cost of repairs was a hardship for these owners and Smith gave "a liberal allowance of time" for repairs to be completed "unless the matter be one of immediate danger to health". Residents of Hobart, wrote Smith, "must not suppose that all the bad little huts are the property of rapacious wellto-do men and women". 42

After Smlth's departure, faced with the same constraints, the Council maintained a cautious approach to Insanitary housing

40. Ibid 3 May 1905.

41. Ibid 1 May 1906.

42. C1. 30 June 1906. 
but aldermen did not shirk their duty when demolition was required. In December 1910 Mayor Atkins summed up the Council's activity:

Steady progress is being made in remedying the insanitary conditions of many dwellings throughout the city. A number of the most defective have been condemned and their occupation forbidden. Owners of others are being afforded an opportunity of placing their properties in repair, and if they do not do so, then condemnation will follow. 43

To those who regarded this policy as too extreme Alderman Freeman, a large property owner, explained that "While not antagonistic to property owners, the Corporation found it imperative to require the demolition of dilapidaced houses etc., in the interest of the public health". ${ }^{44}$ Although critics like Frances Edwards and the Daily Post urged more systematic demolition and were sceptıcai of the Corporation's efforts, feeling that many hovels were not pulled down to protect the landlords and not the tenants' interests, more attention was given to insanitary housing from 1904 to 1914 than any other decade. 45

The Building Act, which allowed shoddy buildings to be erected, was outdated and needed revision. In 1909 a leading architect, Alan Walker, argued for its repeal. ${ }^{46}$ Under the existing Act, Walker said, "the jerry-builder cannot be got at whilst It can be made the instrument for harassing the man who attempts to put up a modern building". Notices sent by Corporation officials were often'defied because "They have no power to enforce

43. ‥ 6 December 1910.

44. Ibid 4 April 1911.

45. D.P. 31 July, 8 August 1913 for letters by Edwards. 46. M. 2 JuIy 1909. 
the directions which they give and that should not be". Walker thought "a committee of experts" should be appointed to frame a new Building Act and in July 1909 the Tasmanian Institute of Architects offered its services. 47 The City Surveyor also considered that changes were necessary and remarked on "the enormous number of difficulties and loopholes which have to be encountered" when inspecting the construction of new buildings. ${ }^{48}$ A completely new Building Act was not drawn up but amendments to the existing Act were made. The Hobart Building Act 1909 empowered the Council to stop the construction of "any building which is considered unsurtable for the neighbourhood, either in design or value": to enforce the use of "a better class of material" for foundations; and tracings of original plans of buildings had to be deposited at the Town Hall to ensure buildings were not altered during erection. 49 Despite further lobbying by the Architect's Association, "vested interests", alleged Mulcahy, prevented a new Building Act from being passed. 50

While the Hobart Corporation was relatıvely successful in regulating the standard of housing, the supply of housing was a much more difficult problem. From about 1900 to 1914 , as we know, Hobart underwent a building boom. In August 1912 the Mercury wrote that "In the last ten years there has been a wonderful extension of .... [Hobart], while a great part of the centre has been practically rebuilt". 51 Despite this boon, however,
47. Ibid 12 July 1909.
48. Ibid $6 \mathrm{July} 1909$.
49. Ibid; Hobart Building Act 1909.
50. M. 25 August 1913, 8 December 1914.
51. Ibid 20 August 1912 . 
the supply of suitable housing did not meet the demand. In the centre of the city old businesses and dilapidated shanties were replaced by new business premises: in the suburbs the more expensive type of villas, as they were called, were erected for those on a good wage. 52 As Smith had intimated in his reports houses for the working classes were not being built. In June 1906 Smith wrote that "the immediate" demand could be overcome by building 100 four or five roomed houses at rents of between 5s. and $6 \mathrm{~s}$. weekly. 53 In 1912 the City Assessor reported that the number of small tenements, rented for between 4s, and 10s., was "decreasing each year": rental for the new residences being built was a minimum of $12 \mathrm{~s}$. weekly. 54 .

In 1905 Bishop Mercer told the Royal Society that "the provision of workmen's cottages has tew charms for private enterprise. Good investments, giving much less trouble, can be easily found". 55 As the cost of land, materials and labour was high, high rents beyond the means of the working classes had to be charged to obtain a good return on investment. 56 Forking class tenants were also regarded as unreliable and, according to Emily Dobson, landlords were worried by "the moonlight flitting of [these] tenants and the destruction of property". 57 Thus on the one hand the failure of private investment to build working class housing and on the other hand the demolition of insanitary and dilapidated housing created a serious housing shortage. As the Corporation contributed

52. T.N. 2 July 1907; M. 5 May 1908.

53. C1. 30 June 1906.

54. M. 13 November 1912 .

55. T.N. 8 August 1905.

56. M. 12 November 1913.

57. Ibid 16 February 1906; for the situation in Britain see D. Englander, Landiord and Tenant in Urban Britain 18381918 (Oxford, 1983), chapter 3. 
to this shortage, some aldermen advocated municipal landlordism to reduce overcrowding. In June 1904 Alderman Moore moved that the Council consider the provision of houses "for the poorer classes of citizens". 58 He believed that overcrowding was the source of "a great deal of mortality". He spoke of schemes in England, whereby old and insanitary dwellings were bought and improved: this proved a financial success "as well as effecting great sanitary and healthful improvements". The Hobart Corporation should build "a lot of small houses to substitute for those which were condemned by it, and which should be models as to sanitary conditions". Alderman Kerr supported the motion but felt that the cost of land was too high and that the Council should not "come too much into competition with private owners". Other aldermen were sympathetic and no outright opposition was voiced. Letters to the press were favourable and even the Property Owners' Association offered no serious objections. 59 However the committee appointed to report on the proposal must have concluded that it was impractical, as no report seems to have appeared. 60

In March 1905 Alderman Paton proposed that the Council build cottages for Corporation employees, which would, to some extent, relieve the general pressure on housing but his motion received little support. 61 Although the Tasmanian News advocated municipal housing, it thought that this was "too big an undertaking for Hobart aldermen to grapple offhand. If anything practical is accomplished in this direction by the civic authorities it will

58. M. 14 June 1904 .

59. Ibid 9 August 1904.

60. T.N. 16 September 1904 indicates this.

61. M. 14 March 1905. 


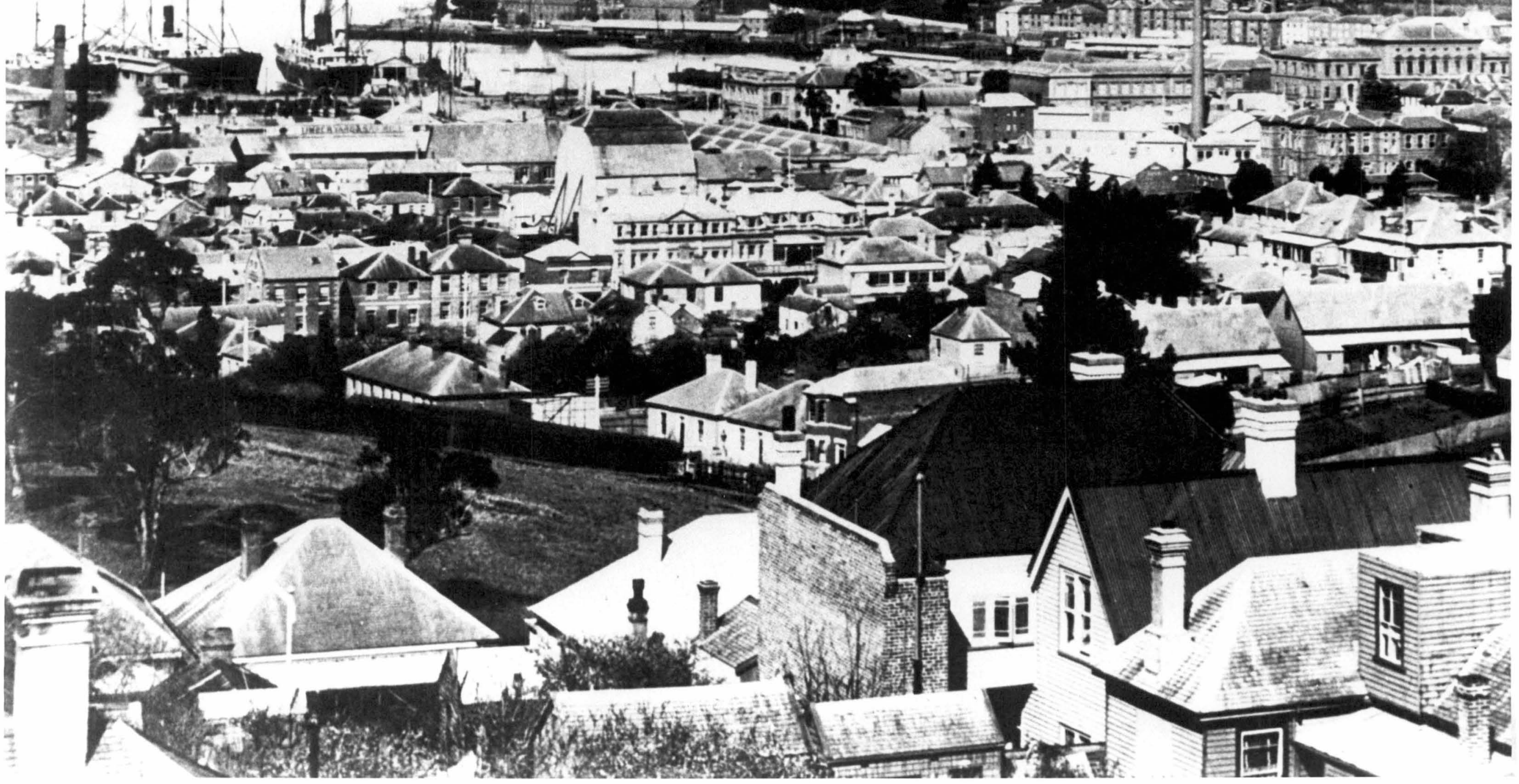


not be for a decade or two". 62 Widespread public disquiet at the housing shortage manifested itself in June 1905. Three members of the Citizens Moral and Social Reform League, formed by Bishop Mercer, prepared an extensive and valuable report on housing conditıons in Hobart. ${ }^{63}$ It conflrmed that insanitary housing abounded but denied that Hobart had slum localities. For example Wapping, situated between Argyle Street, behind the Theatre Royal, and the railway, and along the Hobart Rivulet, was often described as a slum but this was wrong. The area was occupied by "a hardy body of workers, many of whom, at times, earn high wages, being artizans, fishermen and wharf labourers", who preferred to live In cheap dwellings near their place of work. This preference was common amongst workers and should be borne in mind when considering sites for housing schemes. From an analysis of the assessment roll the League members deduced that very few workmen owned their own home and attributed this to the low wages workers were paid. 64 The report established that housing was scarce and outlined a proposal whereby the Corporation could build about 110 houses, ranging from two to four rooms, at a cost of $£ 25,112$, a sum well withın the Corporation's borrowing capacity. The National Council of Women, which had asked Governor Strickland to formulate a working class housing scheme for Hobart, and the Women's Health Association, expressed their determination to solve the housing problem. 65

62. T.N. 29 May 1905.

63. M. 20 June 1905.

64. Another view was expressed in 1912 by Alderman George Smith, as chairman of the Hobart Building Society, who claimed that a worker would rather pay rent "three times over tine value of the house he lived in" than "become his own landlord" see Young, op.cit., p.37.

65. M. 20, 22 June 1905. 
WAPPING c. 1910

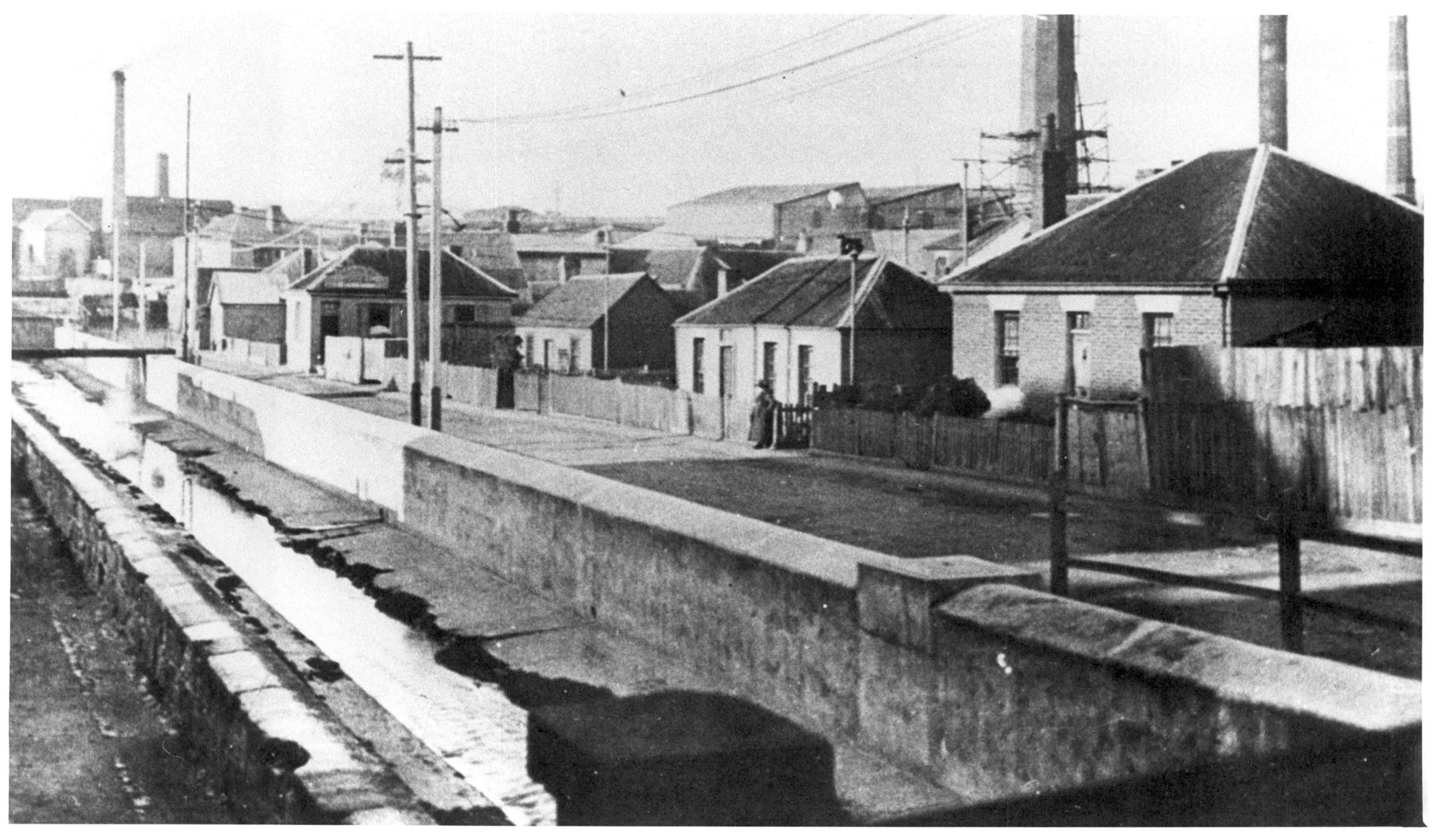




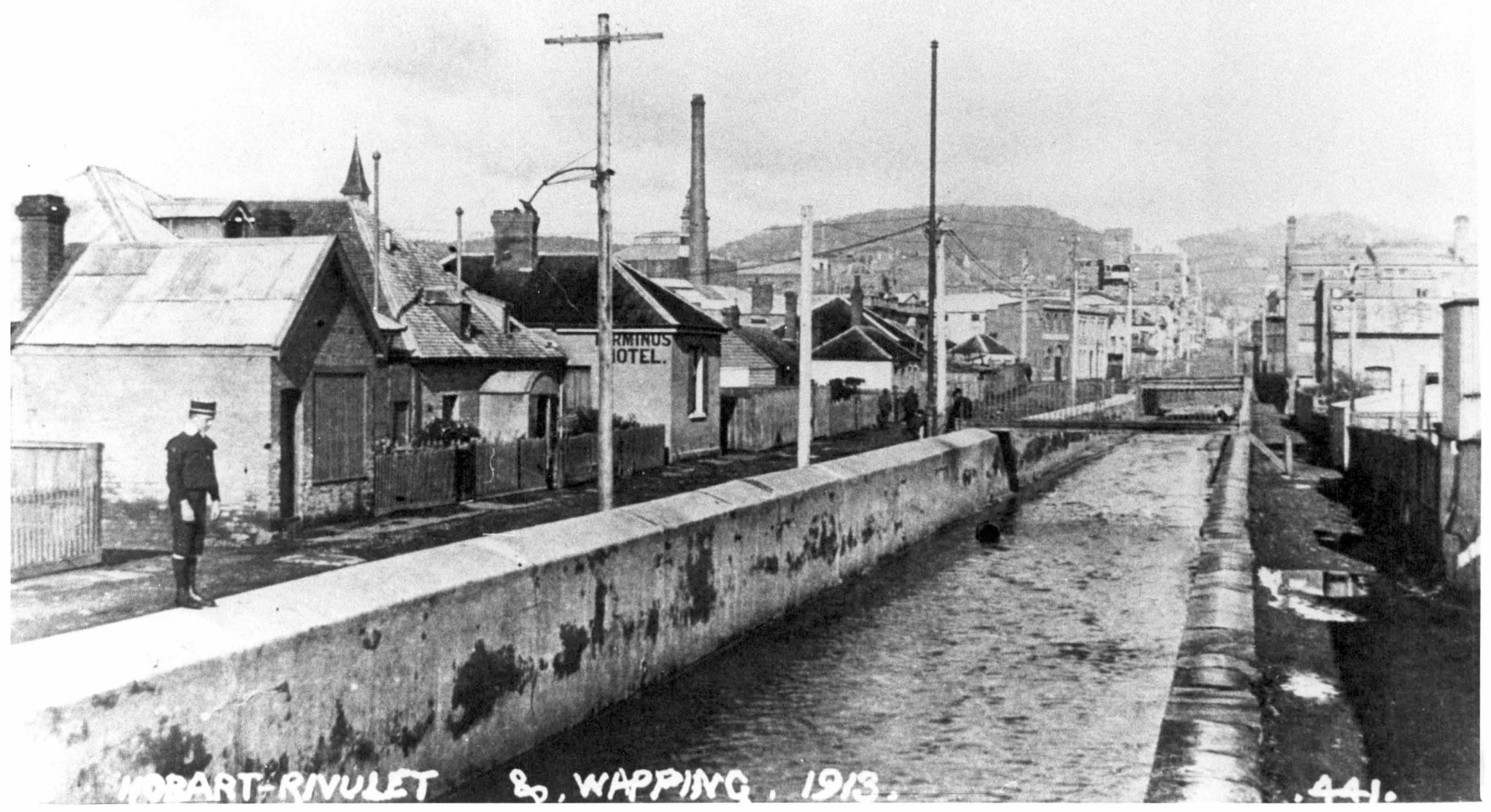


On 27 June a public meeting of these bodies and other influential people set up a general committee "to obtain reports on practical proposals on the housing question". A number of philanthropic schemes were considered and thought useful in alleviating the housing difficulties of "widows, deserted wives, and others unduly handicapped in the struggle for existence" but it was decided that the Council should be induced to embark on "a business scheme" for men earning less than 35s, per week. ${ }^{66}$ The Corporation was approached but the majority of aldermen remained unconvinced that the Council would not lose money and stressed the lack of cheap suitable sites. 67 Each time municipal housing was raised it became clear that financial considerations weighed against it, as Freeman indicated when Mayor in $1908 .^{68}$ It would, he thought, be difficult to keep rents low as money would be borrowed at four percent, one percent would be added for a sinking fund to pay off the loan and two percent for wear and tear: as suitable land at "a moderate sum" was unavailable, the purchase of more expensive sites would add to the rent. The Glasgow Corporation successfully provided housing but the Hobart Corporation, Freeman pointed out, did not own as much land as its Glasgow counterpart and did not derive large sums of money from sources other than rates. 69 A rate of $3 \mathrm{~d}$, or $4 \mathrm{~d}$. in the pound was required and, as large ratepayers, aldermen were "naturally" reluctant to bear this impost. From an economic standpoint housing for the working classes was as unattractive to aldermen as to private investors.

66. Ibid 28 June, 4, 8 July 1905.

67. Ibid $13 \mathrm{July} 1905$.

68. D.P. 7 July 1908 .

69. Ibid 6 August 1908. 
Housing reform retained its adherents. In June 1906 the Benevolent Society was approached to augment the houses erected in 1895. 70 Although it was murmured that the Benevolent Society had between $£ 12,000$ and $£ 13,000$ to invest, it declined as it was not encouraged by the experience of 1895 and only from 1902 had a slight profit been made. 71 In 1908 Milner Macmaster of the Citizens Moral and Social Reform League approached a number of "leading capitalists" with philanthropic leanings to buiid "a class of strong, cheap and useful residences for the poorer sort of people". 72 The idea was abandoned because it was agreed that low rents could not be charged: "fully twenty percent had to be added for wanton depreciation, moonlight flittung, long-deferred payments, involving unnecessary cost in collection, and so on". With the failure of these schemes, it became increasingly clear that the Government, as the Labor Party had advocated, had to play some part. In 1913 the Solomon Liberal ministry, no doubt prompted by Minister of Lands Edward Mulcahy, set aside $£ 5,000$ for the erection of 10 to 12 houses in Wentworth Street, South Hobart, in the Public Works Execution Bill, which after some opposition, Parliament passed. ${ }^{73}$ The main criticism of the measure, which was shared by all political viewpoints, was that the scheme was too small. The Mercury spoke for many when it argued that the Government should look for "a considerable area of land, within reach of the city, and connected either by railway, by tramway, or by ferry, so that men may get to their

70. M. 15 June 1906.

71. T.N. 7 July 1906.

72. M. 23, 25 November 1908.

73. Ibid 18 September, 5 November, 27 November 1913. 
work readily and cheaply". 74 Then a well planned model garden suburb, based on town planning principles that were gaining disciples in Hobart and similar to the Daceyville garden suburb, sponsored by the New South Wales Lakor government, could be developed. In April 1914, before work on the houses was begun, the Solomon government lost office. It was succeeded by the Earle Labor governwent, which had, as part of its platform, State housing on an extended scale. ${ }^{75}$ By October plans for the South Hobart cottages were completed and the Earle government also intended to build cottages on land at Derwent Park and near the New Town Charitable Institution. 76 With these schemes and the extension of the tram system by the Corporation to open up cheap land in the suburbs, the future looked hopeful but housing for those of small means was as scarce in 1914 as in 1904. While wages' rcmained low and landlords were free to charge high rents overcrowding would not be overcome.

b) Noxious Trades

The Corporation slaughteryard resulted in more agitation '. than any other noxious trade. As far back as 1843 the slaughteryard was singled out as a threat to health. Subsequent complaints resulted in cosmetic improvements but the site was at the root of the problem, and from the 1880 s demands for a new site, well away from the centre of the city, gained wide support. In February 1887, for example, the Tasmanian News argued for a new site

74. Ibid 5 November; for a similar view see D.P. 19 December 1913; for Daceyville see L. Sandercock, Cities for Sale: Property, Politics and Urban Planning in Australia, (Melbourne, 1977).

75. P.R. Fagan, "The Earle Labor Government 1914-16: Tasmania's First Effectıve Labor Administratıon", unpublished B.A. Hons. Thesıs, University of Tasmania, 1975, p.29-30 for brief comment on housing policy.

76. D.P. 17 October 1914. 
because people could not pass the slaughteryard "without having .... [their] nasal organs offended by the unsavoury smells which abound in the locality". 77 The buildings were also unsightly. The Corporation often considered an alternative site. In November 1891 the Health committee strongly recommended that the slaughteryard be moved and that the Government be approached to provide land at Derwent Park for a new slaughteryard. 78 Aldermen were unanimous in their condemnation of the existing site. However negotiations with the Government broke down and the new Government elected in August 1892 showed less interest.

In January 1893 owners of businesses in Hunter Street, near the slaughteryard, complained of a terrible stench arising from the sanitary depot. ${ }^{79}$ Giblin investigated and traced the smell to an open drain leading from the slaughteryard onto the beach: he recommended that the drain be covered. His report prompted Alderman Bradley to seek a new site at least a mile from the city boundary. 80 Aldermen were unpersuaded. Crisp regarded the proposal as expensive and "impracticable": John Watchorn argued that it was not proven that the slaughteryard caused fever. The press kept the issue before the public. The Mercury and the Iasmanian News wrote articles condemning the slaughteryard. 81 The Mercury asserted that, although most of the city's meat was killed at the slaughteryard, a "cursory examination" was enough to prove its unsuitability. It was "hemmed in on all sides by higher ground". It had "open drains, inconvenient arrangements, and all the drawbacks customary in an establishment that rather
77. T.N. 28 February 1887.
78. M. 9 November 1891.
79. Ibid 24 January 1893.
80. Ibid 21 February 1893.
81. I.N. 25 February 1893; M. 11 March 1893. 
wears the appearance of being added to perıodically by rule of thumb than built to any sort of plan ...." Only the excellent management of the yards kept the area clean. However "the filtration of refuse from the yards, supplemented by strong doses of ammoniacal water from the gasworks, going on day after day, and year after year, will leave a sediment that, acted upon by the atmosphere, might become dangerous to health". The major advantage of the site was the proximity to railway and marine transport and to butchers but the cost of upgrading the facilities and keeping the yards clean would cost more than building a new site, where meat could be slaughtered "under proper sanitary conditions". In March 1893 the Sanitary Associations added their voice to demands for a new site. 82

Faced with protests on all sides, the Corporation decided to lay new drainage. A petition, prepared by the Sanitary Associations, containing 1012 signatures, criticised the decusion and demanded a new site. 83 The Chief Secretary wrote to the Council that if it decided to move the yard, the Government would sell it part of the Derwent Park estate. 84 In opposition to these efforts, 600 citızens who benefited from the site, mainly butchers and auctioneers, petitioned the Council not to give in because the price of meat would increase, which could not be afforded during a depression. 85 The petitions placed the Corporation in a dilemma: any decision would alienate a substantial number of ratepayers. The best course was to do nothing and hope the Issue would be forgotten. This had worked before and might have

82. Y. 18 March 1893.

83. IDiC 11 April 1893.

84. IbId 18 April 1893.

85. Ibid 23 April 1893. 
succeeded again but a report from Alfred Mault sustained debate. 86 His report of 29 April reiterated the defects described by the Mercury and concurred that to correct them would be costly. Mault highlighted the shortcomings and dangers of the site. On one side was the gasworks, the fumes from which affected the flavour of meat. Within 100 yards of the meatsheds was the Hobart Rivulet, which at this point was in its worst condition where "the greatest quantity of sewage matter" accumulated. About 150 yards away was the sanitary depot. He concluded that an abattoir could not have "three more objectionable neighbours" than "a large gasworks, a shallow open tidal sewer, and a nightsoil receiving-shed and loading-wharf".

On 15 May, in an attempt to reach a decision, Alderman Seabrook proposed a poll of ratepayers to determine "in favour or against the abattoirs being taken not more than two miles from the city". 87 He estimated the cost of connecting a branch of the Main Line railway to Derwent Park and the cost of land at $£ 3,000$ and the building costs of a new slaughteryard at $\_9,000$. Opposing the proposal Crisp argued that it was "inopportune" to embark on such a large outlay "when everything had to be cut down and greater economy practiced in every household". He preferred to spend $£ 1,000$ cleaning up the existing yard. A plea for economy was always regarded sympathetically by aldermen and only Bradley supported Seabrook. Improvements were made: drains were covered in to minimise "unpleasant smells", the old pigsties were demolished and replaced by paved sheep pens and all buildings were "thoroughIy whitewashed". 88

86. T.P.P. $1893 / 75$.

87. M. 16 May 1893.

88. Ibid 5 December 1893. 
Further superficial improvements in subsequent years quelled public agitation, but by 1900, when the Corporation was subjected to searching analysis, the slaughteryard did not escape the gaze of reformers. In April 1900 Alderman Samuel Benjamin initiated steps to remove the abattoir. 89 Despite the improvements, he believed that the abattoir was a grave threat to health. He stressed "the primitive and altogether defective system of drainage"; the proximity of the sanitary depot; and, a new threat, the chance of "contagion and disease being circulated tnrough, and by, flies and other means" because of the growing nearby tip. He appealed for "united action in the interests of health and progress" to secure the removal of the abattour. A special committee was appointed to examine "all matters relating to the existing slaughteryards". By December no action had been taken and Benjamin insisted on an explanation. 90 Mayor Davies replied that the Corporation lacked the power to sell the land upon which the existing slaughteryard was built: it was only vested with the Council while it was an abattoir. The Corporation hoped to use the money ganned from the sale of the land to contribute to the cost of the new slaughteryard: negotiations were begun with the Government to seek legislation placing the land under the Corporation's control, free of conditions.

Negotiations dragged on until November 1901 when an influential report by the Slaughterhouse committee of the Corporation, the Secretary to the Lands Department, the Engineering Inspector and the Chief Inspector of Stock considered potentlal sites for a new slaughteryard and chose Derwent Park. ${ }^{91}$ In moving the

89. $\quad$ Ibid 24 April 1900.
90. Ibid 18 December 1900.
91. Ibid 19 November 1901.


adoption of the report Alderman Brownell spoke of "a deep-seated prejudice" against the slaughteryard and the public would "rejoice" at its removal. Acceptance of the proposal depended upon the Corporation gaining favourable conditions from the Government but negotiations soon reached an impasse. The Government offered the Council $\approx 5,000$ for the existing site and the site at Derwent Park free: the Council thought the site was worth $£ 10,000$ and would not accept a lower sum. ${ }^{92}$ The impasse was not broken until, as part of the metropolitan drainage scheme, it was decided to build septic tanks on part of the slaughteryard site. 93 of all the threats to health this was regarded as the most dangerous, and the Corporation accepted the Government's offer. 94

In 1904 the City Surveyor visited Dunedin where new abattoirs had recently been built, to obtain information for the new Hobart slaughteryard. 95 Some attempt was made by farmers, stockowners, auctioneers and butchers to stop the proposal going ahead: also the Mercury claimed that the septic tanks would not be as much of a nulsance as was feared and the Corporation should see them in operation before moving. 96 The Evans government prevaricated and seemed disinclined to provide land at Derwent Park. ${ }^{97}$ The Corporation, now beginning to display a reforming zeal, was committed to building a new slaughteryard and was able to win over the Government. On 21 September 1906 the foundation stone was laid at Derwent Park and on 24 February 1909 the slaughteryard

92. Ibid 27 September 1902; T.N. 29 September 1902.

93. N. 3 November 1903; T.N. 12 November 1903; MCC 16/129/13, p. 391 .

94. M. 3 June 1903; MCC 16/67 p.114, 134.

95. M. 12 April 1904 .

96. Ibid 1 September 1904.

97. Ibid 19 July, 10 September 1904. 
was formally opened. 98 It was a symbol of progress and did much to erase the stigma of reaction. Mayor Hoggins said that the slaughteryard, costing over $£ 31,000$, was built on the most modern lines and that

The sanitation, conveniences and water supply could not be better, the whole constituting a vast improvement on the old slaughteryards, which had been under the condemnation of very many citizens for a long period.

The Minister of Lands, Alexander Hean, described it as "an establishment of the kind, unsurpassed in any State of Australia". The only difficulty was transporting meat to the city. All kinds of vehicles were used, and meat became contaminated and covered with dust. 99 In January 1913 the Department of Public Health issued regulations requiring meat to be transported "in fly-proof vehicles and protected from contamination and pollution by flies, dust etc."100 Butchers were very sluw Lu adupl Lliese reguialions. 101 The success in establishing a new Corporation slaughteryäd was not matched when dealing with other noxious trades. The Launceston Corporation, as we have seen, met with many frustrations in finding a noxious trades area. Before 1900 noxious trades absorbed very little of the Hobart Corporation's attention and a noxious trades area was not seriously discussed until 1895, when Mault reported on noxious trades in the vicinity of Hobart. ${ }^{102}$ There were 14 noxious trades registered in Hobart, one in New Town and one in rural Queenborough, where there was also one un-

98. Ibid 22 September 1906, 25 February 1909.

99. M. 6 April 1909.

100. Ibid 1 January 1913.

101. Ibid 9 May 1916 Sprott's annual report 1915.

102. Ibid 8 July 1896. 
registered trade: 127 men were employed by these 17 noxious trades. After taking into account the expense of providing buildings and accommodation and the reinstallation of machinery, implements and fittings, Mault estimated the cost of removing all the noxious trades from the metropolitan area at $£ 16,900$. This excluded compensation "for temporary or permanent loss of trade" or "for the additional cost of carrying on business" at a new site. Mault considered three sites: Derwent Park, Dog's Ear Point and Geilston Bay, sometimes called Limekiln Bay. He favoured Geilston Bay, on the eastern side of the Derwent. The land was flat; roads to it were well made; it was a deepwater bay making it accessible by water; and water supply was adequate. More important, it would not interfere with "valuable residential areas". The site would cost $£ 6,000$ to purchase and prepare for noxious trades. Mault was aware that the total cost of dealing with noxious trades would prevent his recommendations from being adopted. 'lheretore he suggested that noxious trades "should be subject to stricter control than in the past".

Little more was heard until May 1900 when John Bradley moved that the Corporation proclaim a noxious trades area because, after federatıon, "Many manufacturers" would set up business in Hobart. 103 Alderman Kerr claimed that "the crowding of noxious trades in some parts of the city caused a serious nusance": chimney stacks were "generally far too short". Most aldermen supported a noxious trades area, although Davies warned that exısting factorıes could not be moved without compensation. This caveat halted action but, as Bradley predicted, the desire of manufacturers to open up busıness in Hobart forced the Corporation to reconsider a noxious 
trades area. In April 1906 Charles Metz applied to the Corporation to open a soap and candle factory in, Lower Collins Street, the site of other noxious trades, but the Health committee recommended against it. ${ }^{104}$ Some aldermen contested the recommendation. Alderman Freeman claimed that Smith said there would be no nuisance if Metz took suitable precautions and Mayor Crisp added that Metz undertook to close up his factory and not seek compensation if asked to by aldermen. Further information was to be sought before a final decision was made. Residents and property owners petitioned against the factory and the Health committee adhered to its original decision, which was accepted by the Council. 105

Metz was not deterred. Later in 1906 he began to operate a plant for rendering fat at his premises in Lower Collins Street and applied for permission to continue for a trial period to show that no nuisance would result. ${ }^{106}$ After protests from residents In Lower Collins Street and Sprott, permission was again refused. Metz was ordered to stop work but did not. ${ }^{107}$ Legal proceedings began which led to "an interim injunction for the works to be closed". Early in 1907 the Health committee and Sprott conferred with Elkington to find a site for a noxious trades area. 108 Elkington understood that the Mayor agreed to a temporary noxious trades area in Lower Collins Street, including Metz's factory. ${ }^{109}$ Premier Evans had a minute prepared to that effect, which was

$$
\begin{aligned}
& \text { 104. Ibid } 8 \text { May } 1906 . \\
& \text { 105. Ibid } 22 \text { May } 1906 . \\
& \text { 106. Ibid } 20 \text { November } 1906 . \\
& \text { 107. Ibid } 12 \text { February } 1907 . \\
& \text { 108. Ibid } 5 \text { February } 1907 . \\
& \text { 109. Ibid } 20 \text { February } 1907 .
\end{aligned}
$$


sanctioned by Cabinet. The Corporation was informed before the minute was gazetted and vigorously protested that it was "Inadvisable that any more offensive trades shall be established within the boundaries of the city". Aldermen recognised the value of noxious trades and thought a noxious trades area should be proclaimed near the city but "where settlement is sparse". Sprott was opposed to any noxious trades in the city, particularly in Lower Collins Street because "That quarter of the city was thickly populated with poor people, who had few opportunities of getting fresh air". Metz's factory was next to a Ragged School and, in the short time it was in operation, Sprott had received complaints from "several respectable people, including teachers at the school", that "it was offensive and sickening". No-one liked living near a soap factory and "he did not see why they should stick one down at the backdoor of the poor people in Collins Street". He noted that Miller's Soap and Candle factory was also a nussance to the school but it could not be moved without paying compensation. The Mercury supported the Corporation's action because "There has, for a long while, been a strong feeling agaunst the establishment within the city of more noxious trades". 110 However a site for a noxious trades area should be found because "each new industry .... [was] another step towards creating permanent prosperity for Tasmania". The Tasmanıan News regarded the supposed menace as "a myth": to counteract possible dangers noxious trades should be forced to employ up-to-date appliances. ${ }^{111}$ The Government acceded to the Corporation's demand and instead chose a site at Derwent Park near the slaughteryard, which was gazetted on

110. Ibid 12 February 1907.

111. T.N. 27 February 1907. 
26 February 1907. ${ }^{112}$ This choice was also heavily censured. Aldermen argued that "even if no direct danger to health, or contamination of the meat, is to be feared, it is, as a matter of public policy, inadvisable" to allow noxious trades near an abattoirs. Evans said he had been assured by Elkıngton that there would be no deleterious effects on meat if "proper precautions were taken", and intended to stand firm. A public meeting denounced the decision, but more serious opposition came from the Moonah Town Board. 113 As the site came under the Moonah Board's jurisdiction, the Government had to gain its permission. After receiving a report from Sprott, who was Health Officer to the Moonah Board, permission was refused. ${ }^{114}$ As was noted when discussing noxious trades in Launceston, the Government attempted to pass an Offensive Trades Bill to give it power to override local bodies and establish a noxious trades area on Crown land, where it decided was best. The Bill was defeated, as was an attempt to secure the same power by an amendment to the Crown Lands Act.

The health and comfort of residents did not always win out over the economic benefits to the city that noxious trades could provide. An example was, in 1908, the application by Crisp and Gunn to establish a saw mill and joinery on the southern side of Brisbane Street between Campbell and Park Streets. 115 Such was the importance of the decision that counsel of those for and against the application addressed the Council. 116 Those against

112. Tasmanian Government Gazette 26 February 1907, p.297.

113. M. 13 March 1907.

114. Ibid 28 March 1907.

115. Ibid 1, 31 July 1908.

116. Ibid 28 July 1908. 
were residents in the vicinity, including the Glebe, property owners and "those who were actively engaged in business in the city". Counsel for Crisp and Gunn stressed that the industry was new to Hobart: it would employ 250 men, pay wages of $\$ 400$ weekly and the cost of erection would be $£ 10,000$, thereby helping the building industry. Crisp and Gunn undertook to cause as "Iittle noise" as possible and would build "a very lofty chimney" to minimise the smoke nuisance. The economic argument was telling and possible nuisance easily controlled. Hence the Public Works committee recommended that, on certain conditions, the application be granted. Three aldermen, Hoggins, Kerr and Freeman, owned substantial property holdings in the area but thought the economic benefits to the city were so great that they supported the recommendation, which was agreed to by the Corporation. In 1910 the Corporation passed by-laws regulating factory smoke, which were gazetted in September 1911.117 Factory chimneys were prohibited from emitting "thick smoke for a consecutive period of more than three minutes". According to Sprott, after a year the by-laws. were "not being observed by a number of proprietors of furnaces in the city, and a great nuisance is caused to the citizens". 118 Only legal action would "prevent pollution of the atmosphere by smoke". It is unclear whether legal action was invoked but there were signs that manufacturers were attemptıng to deal with smoke. In September 1913 W.D. Peacock Ltd. purchased "a smoke-preventing apparatus", which was successful in stopping "large volumes of dense black smoke" from coming out of the chimney stack. 119

117. Ibid 18 October 1910; Tasmanian Government Gazette 19 September 1911, p.2350.

118. M. 22 July 1913.

119. Ibid 19 September 1913. 
From 1907 to 1914 a number of sites for a noxious trades area were considered but, wrote the Mercury,

it has always been found that they were beauty spots, or valuable resıdential areas, or something else, which it would be disastrous to spoil. Pressure has been brought to bear and the subject has been dropped. 120

Thus no new industries were established and there was "a loss of trade and money to the community". As was the case in Launceston property interests, supported by residents in the vicinIty of proposed sites, were able to predominate and a noxious trades area was not proclaimed. 121

c) Cemeteries

Hobart was often described, claimed the Critic, "as a city of boarding-houses, cıvil servants, and̀ old burial grounds". 122 In 1892 the Sanitary Association formed a sub-committee on the burial and disposal of the dead and wanted old cemeteries to be closed. ${ }^{123}$ The Corporation seemed not to have entertained the idea until 1897. On 12 July Sprott told the Royal Society that the replacement of earth burial by cremation was "one of the sanitary reforms that must be adopted sooner or later". ${ }^{124}$ Tracing the history of cremation he said that the renewed interest of recent years In England, many countries in Europe and America was "altogether of a sanitary reform and the result of scientific investigation". He contınued:

120. Ibid 26 January 1914; see particularly the reply given by Premier Solomon to protesters from Glenorchy M. 24 April 1913.

121. T.P.P. 1915/34, p.7-8.

122. Critic 11 March 1911.

123. ‥ 5 July, 6 August, 2 September 1892.

124. G. Sprott, "The Disposal of our Dead by Cremation", P.P.R.S.T., 1897, p.13-23. 
01d time usages and prejudices have led many to believe that earth burial is the only Christian method and that cremation is of heathenish origin .... but as we become better acquainted with the life history of disease germs and the part they play in the causation of infectious diseases, we will be forced .... to find a more sanitary way of disposing of our dead than by the present method of burial. Experiments in bacteriology provided the scientific proof that earth burials" may become public nuisances by disseminating the germs of disease, either through the air or contaminating the watercourses, or by the germs being wafted about on particles of dust brought to the surface by the common earth worm". Placing cemeteries on the outskirts of cities was an improvement but "the suburbs of this generation will probably be the centres of business activity in the next". A similar process emerged all over the world. A cemetery was opened on the boundaries of a city and used for one or two generations. As the city grew, dwellings were built closer to the cemetery, which became overcrowded with graves. The cemetery was closed and another site was found further out. Relatives or friends of those buried in the old cemetery had died or no longer had "any interest in it". The results of such "neglect and desecration" were evident in Hobart at the Campbell Street, Davey Street or Trinity Hill cemeteries. Sprott also employed an economic argument. The 10 cemeteries in Hobart occupied 104 acres of land that could be made profitable to the city and the cost of burial was more than cremation. 
In his annual report of 1897 Sprott described the condition of cemeteries as "dismal, tombstones are tumbled down and graves are uncared for". ${ }^{125}$ Drainage from a graveyard on Huon Road threatened the health of residents living below it in Upper Macquarie Street. Most of the graveyards had been closed for over 20 years and had outlived their use: they should be turned into flower gardens or recreation grounds. In late 1898 a special committee of the Corporation investigated the state of the cemeteries. $^{126}$ Meetings were held with the church wardens of the various churches associated with the graveyards but they resisted suggestions that the graveyards be interfered with. ${ }^{127}$ Every year Sprott urged that the "eyesores" be removed, warning that "Most of them were Insanitary and unhealthy with open graves, while decaying bones are to be seen in all of them". ${ }^{128}$ Aldermen, however, seemed unprepared to pursue the matter. In 1910 the Roman Catholic Church removed tombs and converted the burial ground in Barrack Street into a training college with tennis courts but this was done on its own initiative. 129

In March 1911, no doubt with the Catholic Church's Initıative in mind, Alderman Cooper moved that a special committee be appointed "to enquire into the practicability of the Corporation acquiring St. David's Burial Ground". 130 The committee did not meet with a favourable response from the trustees and recommended that "a bill be introduced into Parliament with the object of having the fee simple of the land vested in the Corporation". 131 Notice

125. M. 24 March 1898.

126. Ibid 1 November 1898; T.P.P. 1902/65.

127. M. 22 January, 19 November 1901, 16 July 1902, 21 July 1903. 128. Ibid 3 March 1908.

129. T.N. 24 September 1910.

130. M. 7 March 1911.

131. Ibid 31 October 1911. 
would be given to relatives to remove remains, headstones and monuments within a specified time; if this was not done, the remains would be removed to a portion of the cemetery. The Corporation should convert it into a park and would pay the trustees a sum equal to the amount spent on the upkeep since it had stopped being used as a burial ground, less any revenue received by the trustees during that time. Unhappy with these recommendations, the Diocesan Synod waited on the Premier, Elliott Lewis, seeking power to sell part of St. David's cemetery and to use the money to keep it in "proper order". 132 Lewis's reply was direct. He opposed the Synod's proposal and favoured handing the cemetery over to the Council for public purposes as had been done in England. The Tasmanian News claimed that "the press and the public" were "United with the Premier" because the trustees had held the land for long enough but had not improved it. 133

In December 1911 a Bill to vest St. David's burial ground in the Corporation and embodying the special committee's recommendations was submitted to Parliament but, as it was too close to the end of the session to be fully debared, it was not passed. 134 On 5 December 1912 Lewis reintroduced the Bill. ${ }^{135}$ He went into the history of the burial ground, stressing that the land had been granted on the condition that it be used as a cemetery but since 1872 no burials had taken place. Parliament, he argued, should thus decide "what was the best public use to which the burial ground, so long in disuse, should be applied": he could think of no better purpose "than to make of it another lung for

132. Ibid 6 November 1911.

133. T.N. 6 November 1911 .

134. M. 5, 22 December 1911.

135. Ibid 6 December 1912. 
the city by converting it into a place of public resort and recreation under proper restrictions", following the general lines of the Open Spaces Act in England. Lewis said that he was a member of the Church of England and "many of his forebears" were buried in St. David's, but "he did not have that sentiment about it that some people seemed to cherish". The second reading was agreed to but there was some dispute about what compensation to pay the trustees, who had asked for £500: the Mercury thought $£ 500$ was "absurdly excessive" and "no legal or moral claim can be advanced" for payment. On 6 December a petition from the St. David's Cathedral Board to the House of Assembly protested agajnst the Bill and claiming that other cemeteries were "notoriously in a worse condition" but "were not much under the public eye". 136 The Bill was allowed to drop to give the Diocesan Council a chance to improve the cemetery but it remained untouched. 137

In 1913 the Corporation and the trustees formed a joint committee "to prepare a scheme by which the graves can be preserved and the ground made of some benefit to the citizens". ${ }^{138^{\circ}}$ By July 1914, after "endless interviews with church.authorities" no satisfactory resolution was achieved and it was not until 1926 that St. David's was transformed into a park. ${ }^{139}$ Although in September 1914 the board of management of St. Andrew's Church asked the Corporation to take over its cemetery in Church Street, Sprott regretted, in his annual report, that Hobart remained a city oversupplied with disused cemeteries and badly in need of "open air spaces and playgrounds for children". ${ }^{140}$

136. Ibid 7 December 1912.

137. Ibid 4 October 1913.

138. Ibld 2 December 1913.

139. Ibid 21 July 1914; City of Hobart Centenary Handbook, (Hobart, 1957), p.46.

140. M. 23 September 1914, 9 June 1915. 
Advocates of cremation to replace the cemeteries in use at Cornelian Bay and Queenborough were also unsuccessful. In 1904 the Tasmanian News, using Sprott's 1897 paper as a starting point, argued that earth burial was "wrong. The cremation method is swift, pure, and not harmful to the living, while the process of putrefaction in soil is protracted, loathesome and a menace to the public health". ${ }^{141}$ In 1912 the Daily Post referred to the establishment of the Cremation Society in Launceston and hoped that Hobart and other parts of Tasmania would set up branches to promote cremation. ${ }^{142}$ Despice the enthusiasm of the press, cremation was not taken up by the public or the Hobart Corporation. d) Factory Inspection

Under the Women and Children Employment Act 1884, as we know, police were charged with the duty of inspecting factories but apparently inspection was very sporadic. ${ }^{143}$ In 1891 , when a Bill to replace police with special factory inspectors was presented to the House of Assmelby, Dr. Edward Crowther alleged that the sanitary condition of factories had not improved since 1884. ${ }^{144}$ George Davies defended the polıce, claiming that the Superintendent periodically inspected factories and found all was in order: the appointment of special inspectors was unnecessary expenditure. The Bill was defeated. Another Bill was introduced by the member for North Hobart Windle St. Hill in October 1892. 145 Edward Giblin strongly argued against the appointment of inspectors and held that sweating was not widespread. His

141. T.N. 30 April 1904.

142. D.P. 26 July 1912.

143. M. 1 October 1888 letter by J. Richards, 8 October 1890 . 144. Ibid 22 July 1891.

145. Ibid 22 October 1892. 
view prevailed. The clause appointing new inspectors was struck out and the Bill was ultimately defeated. ${ }^{146}$ In 1893 the Central Board of Health, concerned at factory conditions, suggested that by-laws be drafted on minimum cubic air space but this appears not to have been followed up. ${ }^{147}$ Inspection continued to be in the hands of the police and, although complaints of sweating were not stifled, aldermen hardly ever discussed the condition of factories.

Early in 1902 members of a Royal Commission on the Victorian Shops and Factories Act visited Hobart to assess the operation of the women and Children Employment Act. It was concluded, after interviewing factory owners, that "apparently very little attempt is made to see that the provisions are complied with". 148 Francis W. Lord, joint owner of the prosperous jam manufacturer and fruit exporter W.D. Peacock and Company, which employed over 50 workers, told the Royal Commissioners that sanitary officials did not visit the Hobart factory because the sanitary arrangements were "so well known to be good". 149 Lord believed that "the factorles ought to be well-ventilated and well looked after, and the sanitary provisions especially under proper supervision, and that the work people should feel that they are being physically and morally well cared for; but beyond that .... factory legislation may do harm rather than good". Lord expressed the general view of witnesses when he described interference by Government with the level of wages as "pernicious". James Paton, proprietor

146. Ibid 29 October 1892.

147. Ibid $25 \mathrm{July} 1893$.

148. V.P.P. 1902-3/30; M. 21 March 1902; C1. 7 June 1902.

149. V.P.P. 1902-3/31, p.789-90; Cvclopedia of Tasmania, (Hobart, 1900) v.1, p.591-3 for details of the company's operations. 
of the Clipper, said he was "to some extent a leader in the labour movement" in Tasmania and knew from first-hand the working conditions of Tasmanian factories. 150 In Hobart there was "not the aggravated sweating" that existed "in larger centres". Trade unionism was not strong partly because "men in a small place like this are afraid of being victımised". Paton thought that "generally the masters are closely associated with the men, and kindly disposed".

Herbert Nicholls expounded a more gloomy view to that of Lord and Paton. In August 1902 he drew the attention of the House of Assembly to the "defective" methods of factory inspection. 151 He moved that the law be amended to apply "to men as well as to women and children and .... be administered by the State Instead of the Municipalities". Nicholls obtanned information on many factories and found that the health of workers "was about as bad as could be". The number of factorıes in Tasmania was not large and all could be "thoroughly and rigorously inspected" to protect employees from becoming sick or injured "through the selfishness and greed of employers". He was told by people "whose testimony was reliable and conclusive" that "the majority of the workrooms throughout Hodart (and they were no better in other parts of the State) were absolutely without ventilation at all: that in such places crowds of girls, boys and other operatives worked together hour after hour, until the air became very foul and poisonous". No improvement was possible while the Act was administered by the City Council, which would be "flying in the faces of plural voters by interfering". Premier Lewis supported Nicholls.

150. V.P.P. $1902-3 / 31$, p.792.

151. M. 23 August 1902. 
W.B. Propsting believed employers would not oppose the motion because it was in their interests to have healthy workers. W.A. Guesdon argued for the appointment of a Select Committee because the sanitary condition. of factories was "filthy". The motion was passed on the voices.

The debate caused consternation in the Corporation. 152 Thomas Bennison noted that the police were no longer under the control of the Corporation and George Moore argued that it was the duty of the Central Board of Health to carry out the sanitary provisions of the 1884 Act. Gould thought that female inspectors or doctors should be appointed inspectors. Later Nicholls introduced amending legislation to appoint special inspectors and giving the Government power to inspect and improve the conditions of factories if the local board did not and to recover costs from it: after being passed in the Assembly the amendments were defeated In the Legislative Council. 153

In December 1902 Alderman Moore, prompted by growing demands for reform of factory inspection, urged the appointment, for a trial period, of a female inspector to inspect factories where women and children were employed. ${ }^{154}$ A salary of $£ 100$ was suggested but was considered to be too high and the motion was lost. In May 1903 an alternative proposal to appoint a qualified nurse as female inspector at $£ 78$ per annum was adopted: in June Ethel B. Keach was appointed. 155 The Tasmanian News was very enthusiastic, and wrote of the success of such appointments in New Zealand. 156 A female inspector would be a great boon to Hobart,

152. Ibid 26 August 1902.

153. Ibid 20 September, 10 October, 21 November 1902.

154. Ibid 2 December 1902.

155. Ibid 30 June 1903.

156. T.N. 21 May 1903. 
a city "absolutely uncontrolled by proper industrıl and sanitary regulations". In November legislation to transfer supervision of factories from the police to an officer appointed by the Hobart Local Board of Health was passed. 157 Although insufficient evidence survives to assess Keach's work, according to Gerard Smith, writing in August 1905, her appointment had been "amply justified". 158 He claimed that

Her periodic visits to workshops and factories in which girls and women are employed have been extremely useful, and great improvements have been made in the working conditions in many of these places in consequence of Miss Keach's recommendations to the Board.

Apart from the Clipper, working conditions and sweating in factories aroused little public comment. ${ }^{159}$ This dramatically changed after the suicide of a 16 year old girl Olive Coulson. 160 She was in charge of "a cash desk in a big city establishment". She earnt 7s. 6d. a week but often $\lesssim 100$ a day passed through her hands. She yielded to temptation, stole some money and was caught. Shamed by her misdeed and fearing legal action, the girl drowned herself in "the depths of the Derwent". W.A. Woods, a Labor politician and editor of the Clipper, asked "Was she to blame? Or the system?" To ham the answer required little contemplation: the system. Labor, and some Liberal, politicians fiercely sought an enquiry into sweating, not just in Hobart, where the worst conditions, they alleged, prevailed, but through-

157. M. $13,20,25,27$ November 1903.

158. Ibid 15 August 1905.

159. For example see Cl. 15 July 1905.

160. The following is based on a lecture given by W.A. Woods published in the C1. 24 March 1906; for a.picture of Coulson see C1. 28 March $\overline{1906}$. 
out Tasmania. As noted in chapter five a Royal Commission was appointed but the evidence gathered was so damaging that it was suppressed.

The Tasmanian News angrily denounced the suppression. In the last session of Parliament, it wrote, "Harrowing pictures were drawn of suffering humanity in various establishments and the weary, toilsome, darksome ways they were compelled to tread to keep the wolf from the door" and the public had a right to know the details of the reporc. ${ }^{161}$ The Clipper wanted to see the evidence given by the Health Officer and Lady Inspector on the sanitary condition of factories and wondered if they had included such evidence in reports to the Corporation. ${ }^{162}$ If they had, the Clipper mused "why the matter has never been deemed worthy of publicity by aldermen". In June 1907 Woods wrote to the Council asking for copies of reports received "by the Health Committee from its inspectors regarding the sanitary conditions of Messrs. Jones and Co's jam factory". ${ }^{163}$ A motion by Alderman Hoggins was passed, informing Woods that the Corporatıon had received such reports but that the Health committee "did not deem them to be of such a nature as to necessitate action being taken by the board". Departmental reports were usually "not made available for the public" and the Council adhered to this practıce. At the same meeting a report by Sprott on Jones and Co. was tabled. He found that separate toilet accommodatıon for men and women

161. T.N. 1 May 1907.

162. Cl. 15 June 1907.

163. M. 25 June 1907. 
was "private and good" and that "The whole surroundings were clean and well kept". The Clipper asserted that as Sprott's brief report was "totally at variance with the implications conveyed in the Wages Commissioner's Report, the position demands that the evidence should be published at once". 164

The evidence, however, stayed suppressed and the Royal Commission produced no immediate benefits for workers. Attempts to introduce progressive industrial legislation were checked by the Legislative Council but a bitter debate occurred in 1910 when Bishop Mercer, a committed social reformer, described working conditions for women and girls as "little less than slow murder". 165 Mercer's allegations were heatedly discussed in the House of Assembly and the Daily Post gave full publicity to them. In one of many editorials it wrote

Long hours, bad working conditions, insufficient and unsuitable food, can have only one result, and before they are twenty these girls are anaemic, liable to rheumatism and nerve troubles and otherwise broken in health. 166

Such working conditions were a major cause of "race suicide". The suppression of the 1907 Royal Commission evidence was "itself absolute proof of the bad conditions in many industries" and conditions were no better in 1910. ${ }^{167}$ In September 1910 the Daily

164. C1. 13 July 1907.

165. D.P. 26 August 1910; R.P. Davis, Bishop John Edward Mercer: A Christian Socialist In Tasmania, Lniversity of Tasmania Occasional Paper 34 (Hobart, 1982), p.12-14.

166. D.P. 26 August 1910.

167. Ibid 31 August 1910. 
Post printed extracts from the evidence volume to support its accusations. 168 The weight of opinion was too united for the Legislative Council to override; the Factories and Wages Bills were passed. Under the Factories Act 1910 a more complete registration of factories was made and local authorities were required to carry out "regular and proper inspection" of factories. 169 "Many defects", Sprott wrote in his 1912 annual report, "were found and reported to the Department of Public Health". 170 Sprott was "strongly of the opinion" that the Corporation "should control the sanitary condition of factories within its boundaries" and wanted legislation empowering the Corporation "to serve notices to remedy defective conditions as soon as discovered". Generally, however, the record of factory inspection by the Hobart Corporation was not good and the trend was to strengthen centralised control rather than to weaken it.

This chapter confirms the view that public health reform was a political issue. Vested interests in the areas of housing, noxious trades, cemeteries and factory inspection halted the Implementation of sanitary reform by applying pressure inside and outside the Council. Thus, because of their voting power at municipal elections, property interests forestalled the provision of municipal housing and the establishment of a noxious trades area and factory owners were apparently able to escape the rigorous enforcement of factory legislation. Religious interests, whose influence at municipal elections was minimal, used Parlia-

168. Ibid $1,2,5,6,8$ September 1910.

169. T.P.P. 1914/22 p.16 by June 1914237 factories were registered in the Hobart district.

170. M. 22 July 1913. 
366.

ment to thwart the transformation of disused cemeteries into parks. In addition to vested interests the Corporation was constrained by weak Iegislation and, as always, the cost of proposed reforms, such as housing, and the compensation needed to be paid to remove noxious trades from the city. However by removing the old slaughteryard, by refusing permission to new noxious trades to set up business and from 1904 by gradually remedying the condition of insanitary and old housing the Hobart Corporation contributed to improved health and the amenity of urban life. 


\section{CONCLUSION}

In the nineteenth century Tasmania won renown as a sanatorium and people were attracted to the island in the hope of restoring failing health or attaining longevity. However as the populations of the two major cities, Hobart and Launceston, grew and as man failed to attend to the public health problems that such a growth caused, outbreaks of infectious diseases occurred. Not only did these outbreaks seriously endanger Tasmania's reputation as Australia's pre-eminent health resort, but also they threatened the lives of urban residents. Municipal councils, from their establishment in 1852, were charged with the responsibility of improving the sanitation of Hobart and Launceston but, apart from building waterworks, were generally lax. Epidemics jolted the two Corporations out of their complacency. In 1875 epidemics of typhoid and measles highlighted past neglect. The immediate response of the two Corporations was disappointing. The Hobart Corporation appointed a Health Officer but this appointment was an empty gesture as aldermen gave him no support: the' Launceston Corporation did nothing. Another typhoid epidemic in 1883 produced better results. In both cities cesspits began to be closed up and Launceston appointed an energetic Sanitary Officer. By 1885 rudimentary efforts to improve sanitation, prompted by epidemics, had been made but much was left undone. A new era of concern for the public health was ushered in by the enactment of the Public Health Act 1885, which strengthened the powers of munzcipal councils and also introduced for the first time the threat or possibility of central intervention by the newly constituted Central Board of Health. The principal aim of this study was to find out what was achieved by the two Corporations between 1886 and 1914 . 
Probably the main reason why sanitation was neglected before 1885 and why sanitary reform received opposition afterwards was economic. In both cities the major source of municipal revenue was rates levied on real property. Property owners, especially those gaining most of their income from rent, and indeed all ratepayers, had a vested interest in keeping rates low and opposed expenditure on sanitary improvements if rates would be increased. Most property owners could see no direct benefit to themselves from sanitary improvements: as munıcipal finances were limited they wanted priority given to other areas such as street building or lighting. Only during times of general economic prosperity, when building was stimulated and the annual rateable value of property increased, leading to extra municipal revenue, were sanitary improvements introduced. In both cities refuse removal, for example, was begun without adding to the rates. Property owners seemed not to have opposed borrowing large loans for sanitary measures if repayment was spread over many years and did not become a short-term burden.' Thus in certain circumstances sanitary reform was possible without antagonising property owners.

That the views of property owners usually prevailed was assured by the restrictive property qualifications for election to alderman and plural votıng. Aldermanic candidates had to espouse a commitment to low rates to win election and, to retain their seats, adopt a very cautious approach to municipal finances. Hence ownership of property made for conservatism and stability In municipal affairs, particularly in Hobart. In the 1890 s liberalism gained in popularıty and liberal inspired municıpal reform movements in both cities agitated for the democratisation of the Corporations and the abolition of property restrictions. In 
Hobart democratisation, it was hoped, would force the Corporation to attend to the needs of the city, particularly sanitation: in Launceston democratisation was seen as desirable in itself as the Corporation was generally regarded as progressive. While not totally successfu1, by 1915 definite advances in lessening the influence of large property owners in municipal affairs were made but the ultimate objectives of enabling every ratepayer to stand for alderman and one man one vote were a long way off, being blocked by the Legislative Council, itself the bastion of conservatism and property interests.

In addition to resisting expenditure on sanitary improvements, the insidious influence of property owners manifested itself in other ways. They resented attempts by the urban councils to enforce building regulations and to demolish insanitary housing and, as a result, such attempts in both cities were short-lived. A combination of the high cost of construction, making a worthwhile profit unlikely, and a reluctance to be seen to be competing with private investors prevented aldermen from undertaking municipal housing programmes. Thus, compared with British Corporations, the attention given by the Hobart and Launceston Corporations to housing was derisory. Property owners also keenly protested that property values would depreciate whenever it seemed that a noxious trades area would be proclaimed near their holdings and were often supported by residents, who saw noxious trades as threatening the amenity of their homes: these protests succeeded in delaying the proclamation of a noxious trades area in both cities. Other interest groups successfully opposed, or limited the effectiveness of, sanitary measures. Factory owners, the extent of whose influence in municipal life requires further 
research, were apparently able to resist the vigorous application of the sanitary clauses of industrial legislation and factory inspection was eventually centralised. Religious interests used their influence, mainly in Parliament, to prevent municipal interference with their neglected private cemeteries. Thus municipal regulation of the activities of private interests in order to advance the public welfare was unacceptable.

In the face of the pressure exerted by these interest groups aldermen, who had no special training in preventive medicine, were more likely to place economic and political considerations ahead of the arguments used by Health Officers in their reports on sanitary conditions. The investigations of Health Officers helped educate and shape public opinion on sanitary matters but they had no power to ensure their recommendations were enforced and they met with many frustrations. Without the support of aldermen the effectiveness of the work of Health Officers was severely circumscribed. Only a centralised Department of Public Health, with wide and well-defıned powers, could overcome the pressure of vested interests.

It would be unfair, however, to stress the forces resisting municipal endeavour to the exclusion of the successes that were achieved. The period 1886 to 1914 saw what amounted to a transformation of municipal government in Launceston and Hobart as both Corporations acquired public utilities and extended their powers in various ways to promote the welfare of urban residents. This was part of an international trend. Towards the end of the nineteenth century, as urban populations increased, a najor preoccupation In countries throughout the world, including Australia, was how to make cities healthier, happier and more comfortable 
places in which to live for all residents and it appeared that the only way to achieve this was some form of public intervention. 1 Typically public intervention was first required to protect the public health and then followed public provision of gas, electricity, trams and housing. In Australia intervention in these areas could be undertaken by municipal governments, State governments or specially appointed State government boards. ${ }^{2}$ In comparison with other, larger Australian cities, the State government or specially appointed boards were very much less important in Hobar's and Launceston and, apart from the Metropolitan Drainage Board in Hobart, were not used to carry out municipal functions. By 1914 the Launceston and Hobart City Councils had probably acquired more functions than other Australian Corporations and took on more of the character of British Corporations. A desire to maintain local autonomy on the one hand and strong dislike of centralisation on the other, as shown by the reaction to the establishment of the Central Board of Health, help to explain the accumulation of municipal powers. If private enterprise could not or would not provide essential public utilities it was far preferable to have municipal control than to centralise their management as Liberal and later Labor politicians seemed inclined to do. In Launceston the extension of municipal powers was well under way before 1900 and was made possible by a widely held civic pride and a strong sense of community. Thus there was a general desire to make Launceston a model and up-to-date city and this was achieved by the entry into municipal life of public spirited businessmen, who

1. A. Sutcliffe, 'lowards the Planned City: Germany, Britain, the United States and France 1780-1914, (Oxford, 1981) and L. Sandercock, Crties for Sale: Property, Politics and Urban Planning In Australia, (Melbourne, 1977.

2. G.H. Knibbs, Local Government in Australia, (Melbourne, 1919). 
saw a progressive Corporation as an agent of urban growth. In Hobart civic pride or civic consciousness was lacking before 1900: the Corporation, too concerned with the narrow interests of property owners, was an inert body, devoid of public confidence. By 1914, however, civic pride had gradually developed and was powerful enough to override much of the resistance of property owners: public spirited businessmen took a greater interest in municipal affairs and the Hobart Corporation became, like the Launceston Corporation, a dynamic force in the city. That is it took practical steps to respond to the perceived needs of urban residents.

The strength of civic pride had a direct bearing on how the two Corporations responded to epidemics of infectious diseases, particularly of typhoid, occurring more frequently from 1887. As typhoid was thought to be caused by filth, the Launceston Corporation responded quickly by clcaring the environment of wastes, such as refuse, abolishing cesspits and waterwashed pits and extending the sewerage scheme. In Hobart the response of the Corporation was characteristically tardy and no action was taken. Hence in the 1890s a sanitary reform movement, as part of the wider municipal reform movement, emerged in Hobart to pressure the Corporation to attend to sanitation. Failing in the short term, the sanitary reformers sowed the seeds of the civic consciousness that bloomed after 1900, when the environment was cleared of wastes. Thus the shock impact of epidemic diseases, coupled with civic pride, were key spurs to sanitary improvement. Although further research is required to assess the influence of factors such as improvements in nutrition, the availability of hospital provision and medical treatment and the general improvement 
in the standard of living it seems likely that sanitary improvements implemented by the Corporations were mainly responsible for the lowered death rate in the two cities by 1914. Thus the efforts of Health Officers, sanitary reformers, progressive aldermen and perhaps most crucially newspaper editors, imbued with the sanitary idea, ultimately helped save many lives and by making the cities of Launceston and Hobart much cleaner, gave substance to the claim that Tasmania was indeed the Sanatorium of the South. 


\begin{abstract}
APPENDIX A
List of questions asked by the Sewerage committee of the Launceston Corporation on the health of the town in 1883 and submitted to doctors and other interested parties.
\end{abstract}

1. Are you aware whether any epidemic is at present prevalent in Launceston and suburbs?

2. If so, what is its nature?

3. To what do you attribute it?

4. Is the disease limited to any localities or can you trace it along any well-defined lines?

5. Have you any means of knowng the condition, as to cleanliness, of the premises in which the sickness exists?

6. Have the cases of fever that have come under your observation arisen on the spot, or have any of them been brought from other localities?

7. What is the state of the drainage: is it connected with a mann sewer: if so with which, and is it trapped?

8. What kind of closet is used, and what is its condition? 9. Is any provision made for collecting ordinary house and yard rubbish, and its frequent removal?

10. Are you able to speak as to the accommodation generally existıng in lodging-houses and the homes of the industrial classes? 11. Do you think that the cleansing of private premuses by offucers of the Corporation would tend to promote the health of the community?

12. Have you had any experience in the use of earth closets, and do you think the general adoption of that system would be beneficial? 
13. Do you think it desirable to discourage the erection of dwelling-houses on the Swamp, and to prevent any further alienation of it for that purpose?

14. Do you consider that any particular portion of the town is subject to fever of the typhoid character more than any other? 15. Would it be desirable to increase the number or extent of the recreation reserves in Launceston?

16. Do you consider the present system of drainage into the river objectionable, and that any injurious effects arise from the large area of mud flats exposed when the tide has ebbed? 17. In your opinion is a Health Officer required for this town?

18. What in your opinion should constitute his ordinary duties? Source: Ex. 13 October 1883 p.6. 


\section{BIBLIOGRAPHY}

PRIMARY SOURCES

I. Local Government

a. Hobart City Council

Manuscript

b. Launceston City Council

i) Manuscript

ii) Printed

II. Tasmanian Government

a. Manuscript

b. Printed

III. Victorian Government

IV. Newspapers

a. Hobart

b. Launceston

v. Almanacs and Directories

VI. Articles, Books and Pamphlets

SECONDARY MATERIALS

I. Bibliographies, Indexes and General References

II. Books

III. Articles

IV. Theses 


\section{$\underline{\text { BIBLIOGRAPHY }}$}

\section{PRIMARY SOURCES}

I. Local Government

a. Hobart City Council

Manuscript

Held at the State Archives Office, Hobart.

LA 26/1 Letterbook of the Secretary to the Local Board

LA 26/4 Minutes of the Local Board of Health 1886-1915.

MCC 16/1 General correspondence 1843-1904.

MCC 16/7 Town Clerk's letterbooks 11 January 1853-

21 September 1918.

MCC 16/9 Legal opinions and associated papers 1854-1910.

MCC 16/19 Correspondence, reports and returns forwarded through or by the City Surveyor 1901-2, 1904 .

MCC 16/42 Correspondence considered by the Public Works committee $1889-92,1894,1897,1900,1902-4$.

MCC 16/47 Correspondence considered by the Health and Sewerage committee $1857-70,1875,76,1879-92$, 1895-1904.

MCC 16/51 Correspondence considered by the Slaughterhouse committee $1858-84,1897,1902-4$.

MCC 16/54 Reports of the Engineering Inspector 1901-3.

MCC 16/56 Letterbooks of the City Surveyor 1882-98, 1900-6.

MCC 16/58 Letterbook of the Building Surveyor 1885-8.

MCC 16/65 Minutes of the Waterworks committee 1858-1914.

MCC 16/66 Minutes of the Finance committee 1894-1914.

MCC $16 / 67$ Minutes of the Council meeting as a committee of the whole. 
MCC 16/68 Minutes of the Health and Sanitary committee $1889-1914$.

MCC 16/69 Minutes of the Burial committee 1898-1902.

MCC 16/87 Tenders, contracts and associated papers 1887-1900.

MCC 16/92 Register of licensed milk vendors and dairies 1896-1906.

MCC 16/113 Register of noxious trade establishments and of dairies 1886-1905.

MCC $16 / 129$ Minutes of the meetings of the Hobart City Council 1853-1914.

MCC 16/143 Minutes of the Slaughterhouse committee 1868-98.

b. Launceston City Council

i) Manuscript

Held at the Town Hall, Launceston. Minutes of the meetings of the Launceston City Council $1852-86$.

ii) $\quad$ Printed

Corporation of Launceston, City of Launceston, Tasmania 1915, Launceston, 1915.

II. Tasmanian Government

a. Manuscript

Held at the State Archives Office, Hobart. Colonial Secretary's office files. Chief Secretary's Department files.

These files contain reports and correspondence on public health and local government matters.

b. $\quad \underline{\text { Printed }}$

Acts of the Parliament of Tasmania. 
Hobart Gazette, 1882-1906.

Hobart Town Gazette, 1852-1881.

House of Assemb1y Papers, 1856-1883.

Legislative Council Papers, 1856-1883.

Papers and Proceedings of Parliament, 1884-1914.

Statistics of Tasmania, 1875-1914.

Tasmanian Government Gazette, 1907-1914.

III. Victorian Government

Printed

Royal Commission on Victorian Shops and Factories V.P.P. $1902-3 / 30,31$

IV. Newspapers

a. Hobart

Citizen, 1901.

Clipper, 1893-1909.

Critic, 1907-1914.

Daily Post, 1908-1914.

Mercury, 1852-1873 passim, 1874-1914.

Register and Property Investor's Guide, 1895-1902.

Southern Star, 1882-1883.

Tasmanian Mail, 1891.

Tasmanian News, 1883-1911.

Tasmanian Tribune, $1872-1879$.

b. Launceston

Daily Telegraph, 1881-1914.

Examiner, 1852-1873 passim, 1874-1914.

Federalist, $1898-9$.

Tasmanian Democrat, 1891-1898. 
V. Almanacs and Directories

The Tasmania Post Office Directory.

Walch's Tasmanian Almanac.

VI. Articles, Books and Pamphlets

Button, H., Flotsam and Jetsam: Floating Fragments of

Life in England and Tasmania, an Autobiographical Sketch,

Launceston: A.W. Birchall, 1909.

Cyclopedia of Tasmania, Hobart: Maitland and Krone, 1900, 2 volumes.

Ellery, T.G., "Municipal Government in Australasia", Municipal Affairs (New York), v.6, 1902, p.44-67.

'An English Ex-Mayor', How we Managed our Municipality, Hobart: Mercury, 1890.

Hall, E.S., "Climate and Vital Statistics in Tasmania"

in E.S. Hall and F. Abbott, Results of Five Years Meteorological

Observations for Hobart Town; ...... and Completing a Period of

Thirty Years, Hobart Town: Government Prınter, 1872, p.9-37.

Hall, E.S., "Summary of weather and Health in 1865",

P.P.R.S.T., 1865, P.132-4.

Jamieson, J., "Typhoid in Hobart and the Influence of

Drainage on its Prevalence", P.P.R.S.T., 1902, p.95-9.

Johns, F., John's Notable Australians, Melbourne:

George Robertson, 1906.

Johriston, R.M., "The Health of Hobart", P.P.R.S.T., 1896, p.1-15.

Johnston, R.M. "How Far Can the General Death Rate for all Ages be Relied Upon as a Comparatıve Index of the Health or Sanitary Condition of Any Communzty", P.P.R.S.T., 1887, p.13-25. 
Johnston, R.M., "Remarks on the Observed Periodicity of Death-rate with Suggestions as co its Possible Relation with the Periodicity of Solar and Other Super-terrestial Phenomena", P.P.R.S.T., 1884, P.236-39.

Mault, A., "The Drainage of Hobart", P.P.R.S.T., 1886, p.xxiv-xxxiv.

Mault, A., "Remarks Upon the Disposal of the Sewage of Hobart", P.P.R.S.T., 1893, p.188-93.

Mault, A., "Urban Sanitation", Australasiar. Association for the Advancement of Science, Report of 5th meeting, v.5, 1893, p.176-95.

'New Chum', A Ramble in Launceston, Launceston: Cornwall Chronicle, 1879.

Spence, W.G., Australia's Awakening: Thirty Years in the Life of an Australian Agitator, Brisbane: The Worker, 1942. First published in 1909.

Sprott, G., "The Disposal of Our Dead by Cremation", P.P.R.S.T., 1897, p.13-23.

Sprott, G., "Isolation of Infectious Diseases by Local Authorities", Intercolonial Medical Congress of Australasia, 5th Session, 1899, p.446-57.

Sprott, G., "Tuberculosis", P.P.R.S.T., 1896, p.45-68.

walker, P. Benson (ed.), Prelude to Federation 1884-1898: Extracts from the Journal of James Backhouse Walker, Hobart: O.B.M. Publishing, 1976.

Ward, K.F., "Water and Typhoid", P.P.R.S.T, 1885, p.cxvi-cxxv.

hilkınson, E.H., "Sewage Purification and Disposal", P.P.R.S.T., 1902, P.100-5. 


\section{SECONDARY MATERIALS}

I. Bibliographies, Indexes and General References

$$
\text { Australian Dictionary of Biography, } 9 \text { vols., ed. by }
$$

B. Nairn and G. Serle, Melbourne: Melbourne University Press, 1966-83.

II. Bocks

Ashford, D.E., "A Victorian Drama: The Fiscal Subordination of British Local Government" in D.E. Ashford (ed.), Financing Urban Government in the Welfare State, London: Croom Helm, 1980, p.71-96.

Barrett, B., The Inner Suburbs: The Evolution of an Industrial Area, Melbourne: Melbourne University Press, 1971. Barton, N.J., The Lost Rivers of London: A Study of Their Effects upon London and the Effects of London and Londoners Upon Them, London: Phoenix House, 1962.

Beever, E.A., Launceston Bank for Savings 1835-1970: A History of Australia's O1dest Saving Bank, Melbourne:

Melbourne University Press, 1972.

Bennett, S. and Bennett, B., Biographical Register of the Tasmanian Parliament 1851-1960, Canberra: Australian National University Press, 1980.

Bolger, P. Hobart Town, Canberra: Australian National University Press, 1973.

Bolton, G., Spoils and Spoilers: Australians Make Their Environment 1788-1980, Sydney: George Allen and Unwin, 1981. Briggs, A., Victorian Cities, Harmondsworth: Penguin, 1980.

Brown, J.C., 'Poverty is not a Crime': The Development of Social Services in Tasmania 1803-1900, Hobart: Tasmanian Historical Research Association, 1972. 
Butlin, N.G., Investment in Australian Economic Development 1861-1900, Canberra: Australian National University Press, 1976.

Cannadine, D., "Urban History in the United Kingdom: The 'Dyos Phenomenon' and After" in D. Cannadine and D. Reeder (eds.), Exploring the Urban Past: Essays in Urban History by H.J. Dyos, Cambridge: Cambridge University Press, 1982, p.203-21.

Cannadine, D., "War and Death, Grief and Modernity in Modern Britain" in J. Whaley (ed.), Mirrors of Mortality: Studies in the Social History of Death, London: Europa Publications, 1981, p.187-242.

Cannon, M., Australia in the Victorian Age v.3: Life in the Cities, Melbourne: Nelson, 1978.

City of Hobart, Centenary Handbook, Hobart, 1957. Coghlan, T.A., Labour and Industry in Australia, v.4, South Melbourne: Macmillan, 1969.

Craig, C., Launceston General Hospital - First Hundred Years 1863-1963, Launceston: Board of Management of the Launceston General Hospital, 1963.

Cumpston, J.H.L., The Health of the People: A Study in Federalism, Canberra: Roebuck Society, 1978. Cumpston, J.H.L., The History of Diphtheria, Scarlet

Fever, Measlesand Whooping Cough in Australia 1788-1925, Melbourne: Government Printer, 1927. Cumpston, J.H.L. and McCallum, F., The History of the Intestinal Infections (And Typhus Fever) In Australia 17881923, Melbourne: Government Printer, 1927. Cumpston, J.H.L. and McCallum, F., The History of the Plague in Australia 1900-1925, Melbourne: Government Printer, 1926. 
Daunton, M.J., Coal Metropolis: Cardiff 1870-1914,

Leicester: Leicester University Press, 1977.

Davis, R.P., Bishop John Edward Mercer: A Christian

Socialist in Tasmania, University of Tasmania Occasional

Paper 34, Hobart: University of Tasmania, 1982.

Davis, R.P., "Tasmania" in D.J. Murphy (ed.) Labor in

Politics: The State Labor Parties in Australia 1880-1920,

St. Lucia: University of Queensland Press, 1975, p.389-444.

Dyos, H.J. and Reeder, D.A., "Slums and Suburbs" in H.J.

Dyos and M. Wolff (eds.), The Victorian City: Images and

Realities, London: Routledge and Kegan Pau1, 1973, v.1, p.359-86.

Englander, D., Landlord and Tenant in Urban Britain

1838-1918, Oxford: Clarendon Press, 1983.

Ferrall, R.A., The Story of the Port of Launceston, Launceston: Port of Launceston Authority, 1983.

Fraser, D., "Introduction: Municipal Reform in Historical Perspective" in D. Fraser (ed.), Municipal Reform and the Industrial City, Leicester: Leicester University Press, 1982, p. 2-14.

Fraser, D., Power and Authority in the Victorian City, Oxford: Basil Blackwell, 1979.

Fraser D., Urban Politics in Victorian England: The Structure of Politics in Victorian Cities, London: Macmillan, 1979.

Gandevia, B., "The Medico-Historıcal Significance of Young and Developıng Countries, Illustrated by Australian Experıence" in E. Clarke (ed.), Modern Methods in the History of Medicine, London: Athlone Press, 1971, p.75-98. 
Garrard, J., Leadership and Power in Victorian

Industrial Towns 1830-80, Manchester: Manchester University Press, 1983.

Gellie, W.J., The Story of Launceston and its Surrounding Districts in Tasmania, Launceston, 1952.

Giblin, R., Urban Renewal in Inveresk, Canberra: Australian Housing Research Council, 1980.

Glick, T.F., "Science, Technology and the Urban Environment: The Great Stink of 1858" in L. Bilsky (ed.), Historical Ecology: Essays on Environment and Social Change, New York: Kennikat Press, 1980, p.122-39.

Green, F.C. (ed.), A Century of Responsible Government 1856-1956, Hobart: Government Printer, 1956.

Greenwood, G. and Laverty, J., Brisbane 1859-1959: A History of Local Government, Brisbane: Ziegler for the City Council, 1959.

Harris, C.V., Political Power in Birmingham 1871-1921, knoxville: Unıversity of Tennessee Press, 1977.

Hartwell, R.M., "The Economic History of Medical Care" in M. Perlman (ed.), The Economics of Health and Medical Care, London: Macmillan, 1974, p.3-20.

Hays, S.P., "The Changing Political Structure of the City in Industrial America" in A.B. Callow (ed.), American Urban History: An Interpretive Reader, 3rd. ed., New York: Oxford University Press, 1982, p.240-61.

Hennock, E.P., Fit and Proper Persons: Ideal and Reality In Nineteenth Century Urban Government, London: Edward Arnold, 1973. 
Heydon, P., Quiet Decision: A Study of George Foster

Pearce, Melbourne: Melbourne University Press, 1965.

Hobsbawm, E.J., Labouring Men: Studies in the History

of Labour, London: Weidenfeld and Nicolson, 1968.

Hoy, S.M., "Municipal Housekeeping: The Role of Women in Improving Urban Sanitation Practices 1880-1917" in M.V. Melosi (ed.), Pollution and Reform in American Cities 18701930, Austin: University of Texas Press, 1980, p.173-98. Jackson, R.V., Australian Economic Development in the Nineteenth Century, Canberra: Australian National University Press, 1977.

Jones, F.M. "The Aesthetic of the Nineteenth Century Industrial Town" in H.J. Dyos (ed.), The Study of Urban History, London: Edward Arnold, 1976, p.171-82.

Keith-Lucas, B., The English Local Government Franchise: A Short History, Oxford: Basil Blackwell, 1952.

Knibbs, G.H., Local Government in Australia, Melbourne: Government Printer, 1919.

Lambert, R., Sir John Simon 1816-1904 and English Social Administration, London: MacGibbon and Kee, 1963. Leavitt, J.W., The Healthiest City: Milwaukee and the Politics of Health Reform, Princeton: Princeton University Press, 1982.

McBriar, A.M., Fabian Socialism and English Politics 1884-

1918, Cambridge: Cambridge University Press, 1966.

McCord, N., "Ratepayers and Social Policy" in P. Thane (ed.), The Origins of British Social Policy, London: Croom Helm, 1978, p.21-35.

MacDonagh, 0., Early Victorian Government 1830-1870, London: Weidenfeld and Nicolson, 1977. 
Mckeown, T., The Modern Rise of Population, London: Edward Arnold, 1976.

Mckeown, T., The Role of Medicine: Dream, Mirage or Nemesis?, Oxford: Basil Blackwe1l, 1979.

McLaughlin, T., Coprophilia or a Peck of Dirt, London: Casse11, 1971.

McNeill, W.H., Plagues and Peoples, Harmondsworth: Penguin, 1979.

Mayne, A.J.C., Fever, Squalor and Vice: Sanitation and Social Policy in Victorian Sydney, St. Lucia: University of Queensland Press, 1982.

Meller, H., Leisure and the Changing City 1870- 1914, London: Routledge and Kegan Paul, 1976. Melosi, M.V., Garbage in the Cities: Refuse Reform and the Environment 1880-1980, Texas: Texas A \& M University Press, 1981.

Melosi, M.V. (ed.), Pollution and Reform in American Cities 1870-1930, Austin: University of Texas Press, 1980.

Morris-Nunn, M. and Tasse11, C.B., Launceston's

Industrial Heritage: A Survey, Part One, Launceston: Queen Victoria Museum, 1982.

Norman, L., Haunts of the Blue Whale, Hobart: O.B.M. Publishing, 1978.

Offer, A., Property and Politics 1870-1914: Landownership, Law, Ideology and Urban Development in England, Cambridge: Cambridge University Press, 1981. Pelling, M., Cholera, Fever and English Medicine 18251865, Oxford: Oxford University Press, 1978. 
Rees, J., "Urban and Sewerage Services" in P.N. Troy, (ed.), Equity in the City, Sydney: George Allen and Unwin, 1981, p.85-103.

Reynolds, J., Launceston: History of an Australian City, South Melbourne: Macmillan, 1969.

Rimmer, W.G., Portrait of a Hospital: The Royal Hobart, Hobart: Royal Hobart Hospital, 1981.

Sandercock, L., Cities for Sale: Property, Politics and Urban Planning in Australia, Melbourne: Melbourne University Press, 1977.

Schneer, J., Ben Tillett: Portrait of a Labour Leader, London: Croom Helm, 1982.

Shaw, A.G.L., Sir George Arthur, Bart 1784-1854, Melbourne: Melbourne University Press, 1980.

Smith, F.B., The People's Health 1830-1910, Canberra: Australian National University Press, 1979.

Solomon, R.J., Urbanisation: The Evolution of an . Australian Capital, Sydney: Angus and Robertson, 1976.

Stannage, C.T., "Australian Urban History" in G. Osborne and W.F. Mandle (eds.), New History: Studying Australia Today, Sydney: George Allen and Unwin, 1982, p.164-74.

Stannage, C.T., The People of Perth: A Socıal History of Western Australıa's Capital City, Perth: Perth City Council, 1979.

Stedman Jones, G., Outcast London: A Study in the Relationship Between Classes in Victorian Society, Hardmondsworth: Penguin, 1976. 
Sutcliffe, A., "The Growth of Public Intervention in the British Urban Environment During the Nineteenth Century: A Structural Approach" in J.H. Johnson and C.G. Pooley (eds.), The Structure of Nineteenth Century Cities, London: Croom Helm, 1982, p.107-24.

Sutcliffe, A., Towards the Planned City: Germany, Britain, the United States and France 1780-1914, Oxford: Basil Blackwell, 1981.

Tarn, J.N., "Housing Reform and the Emergerce of Town Planning in Britain Before 1914" in A. Sutcliffe (ed.), The Rise of Modern Urban Planning 1800-1914, London: Mansell, 1980, p. 71-98.

Tarr, J.A., McCurley, J. and Yosie, T.F., "The Development and Impact of Urban Wastewater Technology: Changing Concepts of Water Quality Control 1850-1930 in M.V. Melosi (ed.), Pollution and Reform in American Cities 1870-1930, Austin: University of Texas Press, 1980, p.59-82. The Tasmanian Cyclopedia: An Historical, Industrial and Commercial Review, Hobart: Service Publishing, 1931. von Stieglitz, K.R., A History of Local Government in Tasmania, Launceston: Telegraph Printing, 1958. Winter, J.M., "The Decline of Mortality in Britain 1870-1950" In T. Barker and M. Drake (eds.), Population and Society in Britain 1850-1980, London: Batsford, 1982, p.100-20. Wohl, A.S., Endangered Lives: Public Health in Victorian Britain, London: Dent, 1983. Wohl, A.S. The Eternal Slum: Housing and Social Policy In Victorian London: London: Edward Arnold, 1977. 
Wohl, A.S., "Unfit for Human Habitation" in H.J. Dyos and M. Wolff (eds.), The Victorian City: Images and Realities, London: Routledge and Kegan Paul, 1973, v.2, p.603-24.

Woodward, J. and Richards, D., "Towards a Social History of Medicine" in J. Woodward and D. Richards (eds.), Health Care and Popular Medicine in Nineteenth Century England: Essays in the Social History of Medicine, London: Croom Helm, 1977, p.15-55.

Young, K., Local Politics and the Rise of Party: The London Municipal Society and the Conservative Intervention in Local Elections 1894-1963, Leicester: Leicester University Press, 1975.

III. Articles

Bender, T., "The 'Rural' Cemetery Movement: Urban Travail and the Appeal of Nature", The New England Quarterly, v.47, 1974, p.196-211.

Blainey, G., "Population Movements in Tasmania 18701901", T.H.R.A., v.3, 1956, p.62-70.

Davison, G., "Australian Urban History: A Progress Report", Urban History Yearbook, 1979, p.100-09. Dingle, A.E., "'The Monster Nuisance of AlI': Landowners, Alkali Manufacturers and Air Pollution 1828-64", Economic History Review, v.35, 1982, p.529-48.

Dyster, B., "The Port of Launceston Before 1851", The Great Circle, v.3, No. 2, 1981, p.103-24.

Falkus, M.E., "The Development of Municipal Trading in the Nineteenth Century", Business History, v.19, 1977, p.134-61. 
Fisher, S.H., "An Accumulation of Misery", Labour History, No. 40, 1981, p.16-28.

Fisher, S.H., "The Pastoral Interest and Sydney's Public Health", Historical Studies, v.20, No. 78, 1982 , p. 73-89.

Fletcher, B., "Urban Society in Australia: Writings and Approaches", Teaching History, v.17, Part 2, 1983, p.15-30.

Flick, C., "The Movement for Smoke Abatement in 19thCentury Britain", Technology and Culture, v.21, No. 1, 1980, p. 29-50.

Freestone, R., "The Garden City Idea in Australia"; Australian Geographical Studies, v.20, No. 1, 1981, p.24-48.

Garrard, J., "Social History, Politıcal History and Political Science: The Study of Power", Journal of Social History, v.16, No. 3, 1983, p.105-21.

Gerathy, G., "Sydney Municipality in the 1880s", Royal Australian Historical Society Journal, v.58, 1972, p.23-54. Goddard, N., "19th-Century Recycling: The Victorians and the Agricultural Utilisation of Sewage", Hıstory Today, v. $31,1981, \mathrm{p} .32-6$.

Grob, G., "The Social History of Medicine and Disease in America: Problems and Possibilities", Journal of Social History, v.10, 1977, p.391-409.

Hammack, D.C., "Problems in the Historical Study of Power in the Cities and Towns of the United States, 1800-1960", Amerzcan Historical Review, v.83, 1978, p.323-49.

Hennock, E.P., "Finance and Polıtics in Urban Local Government in England 1835-1900", Historical Journa1, v.6, 1963, p.212-25. 
Kellett, J.R., "Municipal Socialism, Enterprise and Trading in the Victorian City", Urban History Yearbook, 1978, p. 36-45.

Leavitt, J.W., "The Wasteland: Garbage and Sanitary Reform in the Nineteenth Century American City", Journal of The History of Medicine and Allied Sciences, v.35, 1980, p.431-52.

Luckin, B., "Death and Survival in the City: Approaches to the History of Disease", Urban History Yearbook, 1980, p. 53-62.

McCarty, J., "Melbourne, Ballarat, Sydney, Perth: The New City Histories", Historical Studies, v.19, No. 74, 1980, p. $1-15$.

McLaren, J.P.S., "Nuisance Law and the Industrial Revolution - Some Lessons from Social History", Oxford Journal of Legal Studies, v.3, No. 2, 1983, p.155-221.

Mayne, A.J.C., "City Back-S1ums in the Land of Promise: Some Aspects of the 1876 Report on Overcrowding in Sydney", Labour History, No. 38, 1980, p.26-39.

Mayne, A.J.C., "'A Most Pernicıous Principle': The Local Government Franchise in Nineteenth Century Sydney", A.J.P.H., v.27, No. 2, 1981, p.160-71.

Mayne, A.J.C., "'The Question of the Poor' In the Nineteenth Century City", Historical Studies, v.20, No. 81, 1983, p.557-73.

Merrett, D.T., "Economic Growth and Well-being: Melbourne 1870-1914, A Comment", Economic Record, v.53, 1977, p. 262-8. 
Parsons, T.G., "Manufacturing on the Banks of the Yarra River, Melbourne: The Development of an Industrial Area", Journal of Australian Studies, No. 11, 1982, p.21-35.

Peterson, J.A., "The Impact of Sanitary Reform Upon American Urban Planning 1840-1890", Journal of Social History, v.13, No. 1, 1979, p.83-103.

Powe11, J.M., "Medical Promotion and the Consumptive Immigrant to Australia", Geographical Review, v.63, 1973, p.449-76.

Roe, M., "The Establishment of Local Self-government in Hobart and Launceston", T.H.R.A., v.14, No. 1, 1966, p. $21-45$.

Roe, M., "Smallpox in Launceston, 1887 and 1903", T.H.R.A., v.23, No. 4, 1976, p.111-48.

Rosen, B., "Australia's Contribution to the Conquest of Plague", Royal Australian Historical Society Journal, v.63, 1977, p.60-71.

Rosen, G., "Social Variables and Health in an Urban Environment: The Case of the Victorian City", Clio Medica, v.8, No. 1, 1973, p.1-17.

Rosenkrantz, B.G., "Cart Before Horse: Theory, Practice and Professional Image in American Public Health 1870-1920", Journal of the History of Medicine and Allied Sciences, v.29, 1974, p.55-73.

Schultz, S.K. and McShane, C., "To Engineer the Metropolis: Sewers, Sanitation and City Planning in Late Nineteenth-Century America", Journal of American History, v.65, 1978, p. 389-411. 
Sinclair, W.A., "Economic Growth and Well-being: A Comment on a Comment", Economic Record, v.53, 1977, p.269-71. Sinclair, W.A., "Economic Growth and Well-being: Melbourne 1870-1914", Economic Record, v.51, 1975, p.153-73. Smith, F.B., "Illness at the Inn: A Review of Endangered Lives: Public Health in Victorian Britain by A.S. Wohl", London Review of Books, v.5, No. 14, August 1983, p.11.

Townsley, W.A., "Tasmania and the Great Economic Depression 1858-72", T.H.R.A., v.4, 1960, p.35-46.

IV. Theses

Button, J., "The Rise and Fall of the Hobart Town Rivulet: An Historic Preservatıon Study", unpublished Graduate Diploma of Architecture Thesis, Tasmanian College of Advance Education, 1978.

Fagan, P.R., "The Earle Labor Government 1914-16: Tasmania's First Effectıve Labor Administration", unpublished B.A. Hons. Thesis, University of Tasmania, 1975.

Haynes, E.F., "Edward Swarbreck Hall: Medical Scientist and Social Reformer in Colonial Tasmania", unpublished M.A. Thesis, University of Tasmania, 1976.

Manıng, R.W., "City Boundary Extension in Hobart", unpublished B.A. Hons. Thesis, University of Tasmanıa, 1969. Morriss,C.A., "In Pursuit of the Travelling Man: A Study of Tasmanian Tourism to 1905", unpublished B.A. Hons. Thesis, University of Tasmania, 1974.

Reynolds, H., "The Island Colony, Tasmania: Society and Politics 1880-1900", unpublished M.A. Thesis, University of Tasmania, 1963. 
Roberts, A., "City Improvement in Sydney: Public Policy 1880-1900", unpublished Ph.D. Thesis, University of Sydney, 1979 .

Taylor, A.R., "Mrs. Henry Dobson: Victorian 'do-gooder' Or Sincere Social Reformer; An Analysis of Her Charitable and Pub1ic Welfare Work in the 1890s", unpublished B.A. Hons. Thesis, University of Tasmania, 1973.

William, V.G., "Local Government Reform 1906-7: A Permanent Panacea?", unpublished B.A. Hons. Thesis, University of Tasmania, 1969.

Young, G., "The Hobart Building Society 1874-1971", unpublished B.A. Hons. Thesis, University of Tasmania, 1971. 